\title{
A Regulatory Guide to Permitting and Licensing in Idaho, Montana, Oregon, and Washington
}

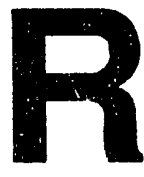

by Gilbert A. McCoy, P.E. Washington State Energy Office
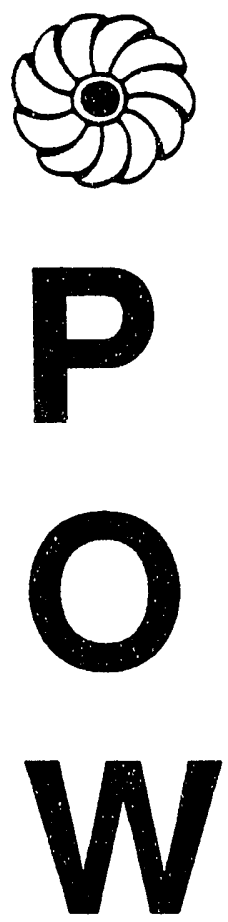

Prepared by the Washington State Energy Office in cooperation with the Idaho Department of Water Resources, the Montana Department of Natural Resources and Conservation, and the Oregon Department of Energy

for

The Bonneville Power Administration Agreement No. DE-BI79-91BP15067
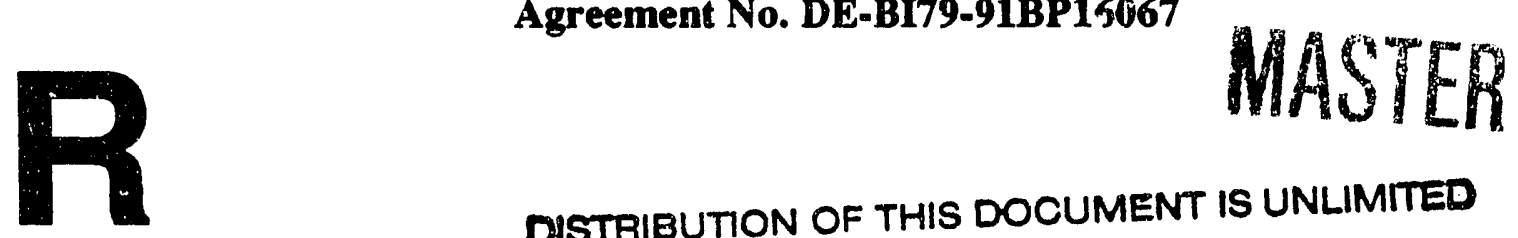

DISTRIBUTION OF THIS DOCUMENT IS UNLIMITED 


\section{Disclaimer}

This publication was prepared for use by interested developers and the Bonneville Power Administration. Neither the Bonneville Power Administration, nor the United States Department of Energy, nor the Washington State Energy Office, nor any of their employees, nor any of their contractors, subcontractors, or their employees, makes any warranty, expressed or implied, or assumes any legal liability or responsibility for the accuracy, completeness, or usefulness of any information presented. The views and opinions of authors expressed herein do not necessarily state or reflect those of the United States Government or any agency thereof. Reference herein to any specific product, process, or service by trade name, mark, manufacturer, or otherwise, does not necessarily constitute or imply its endorsement or recommendation or favoring by the United States Government or any agency thereof.

Please be aware that information included in this guide is subject to change. The Washington State Energy Office and Bonneville Power Administration are not to be held responsible for information that has changed since the printing of this guide. Each legislative session, new laws are developed and old laws are altered or repealed. Agencies may update their administrative codes, increase fees, or reorganize.

Also, there are resource protection requirements that are not listed in this guide. Requirements issued by special districts, such as sewer and water, diking, irrigation, port districts, etc., are not addressed herein. Some requirements may have been inadvertently left out, and in some cases, state agencies chose not to include those requirements that would apply only in rare cases.

The only way to be absolutely sure about permit requirements that apply to your project is to contact the appropriate resource agencies.

\section{Acknowledgements}

The Bonneville Power Administration and the Washington State Energy Office would like to pay special thanks to the author of this document, Gilbert A. McCoy, P.E., of the Washington State Energy Office; to Alex Sifford of the Oregon Department of Energy for his help in producing the Oregon chapter; to Paul Cartwright of the Montana Department of Natural Rescurces and Conservation for his help in producing the Montana chapter; and to Rick Sterling of the Idaho Department of Water Resources for his help in producing the Idaho chapter. Special thanks also go to Char Gruessing of the Washington State Energy Office who was responsible for the word processing of this book.

\section{DISCLAIMER}

This report was prepared as an account of work sponsored by an agency of the United States Government. Neither the United States Government nor any agency thereof, nor any of their employees, makes any warranty, express or implied, or assumes any legal liability or responsibility for the accuracy, completeness, or usefulness of any information, apparatus, prods. Referprocess disclosed, or represents that its use would not inf revice by trade name, trademark, ence herein to any specific commercial product, process, or service by its endorsement, recommanufacturer, or otherwise does not necessarily constitute or imply agency thereof. The views mendation, or favoring by the United States Government or any aressarily state or reflect those of the and opinions of authors expressed herein do not 


\section{Table of Contents}

\section{Introduction}

Resource Characterization and Developmental Constraints .............................................

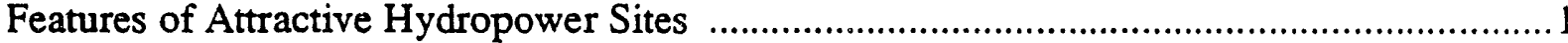

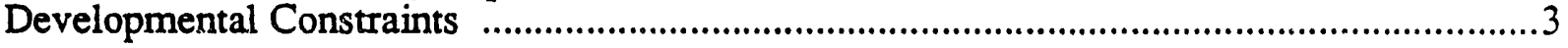

Potential Environmental Impacts and Concerns .............................................................15

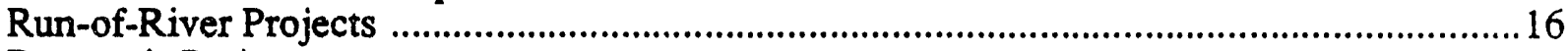

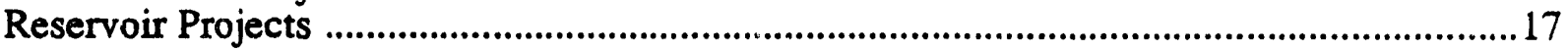

Potential Study Requirements and Impact Assessment Actions ...................................... 18

Chapter 1 - Federal Permit and Licensing Requirements ......25

Federal Energy Regulatory Commission ..............................................................................25

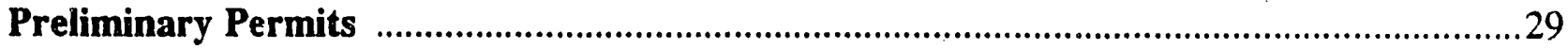

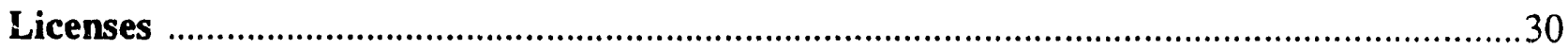

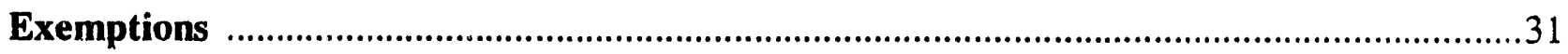

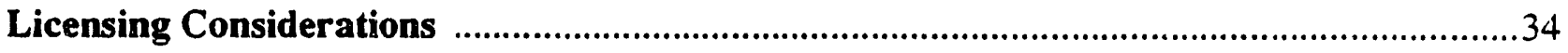

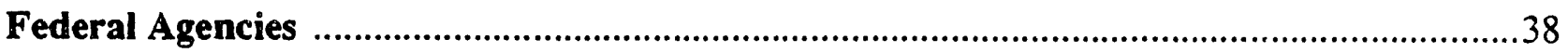

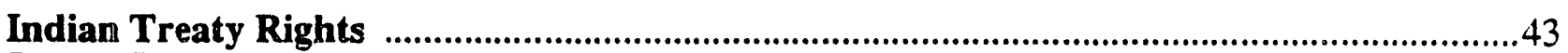

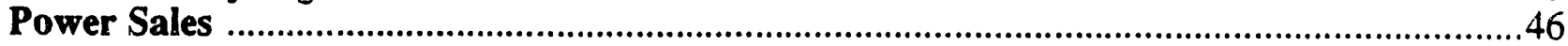

Public Utilities Regulatory Policies Act (PURPA) Overview .........................................46

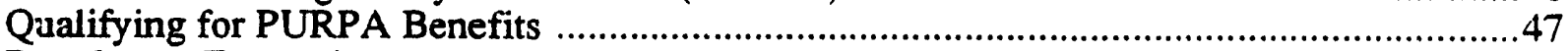

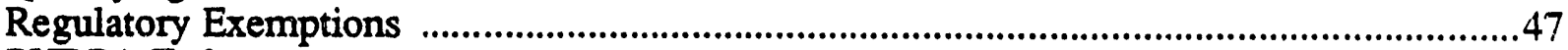

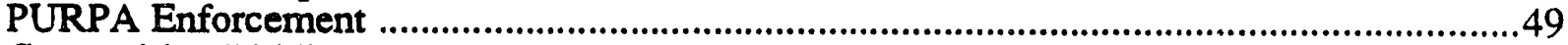

Competitive Bidding

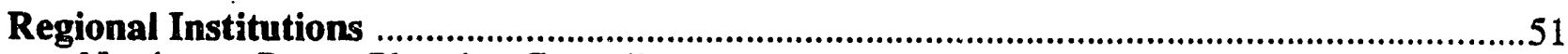

Northwest Power Planning Council .....................................................................................53

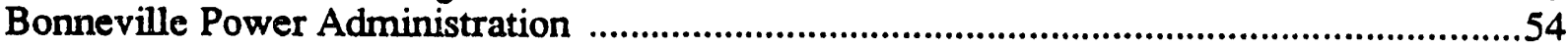

\section{Permit Summary Sheet — Idaho …………………………………………....5}

Chapter 2 - The Idaho State Process ……………………………………..56

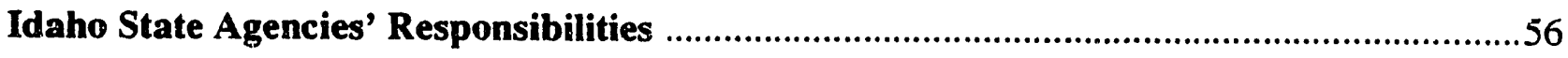

Idaho State Permitting and Licensing Requirements ...................................................63

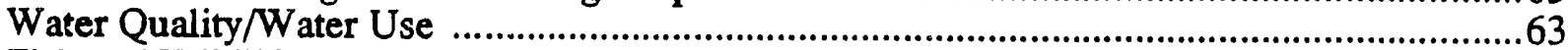

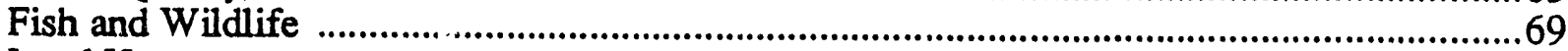

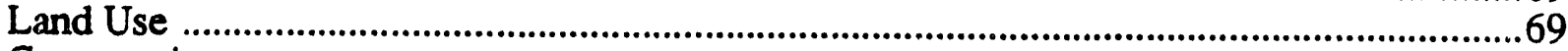

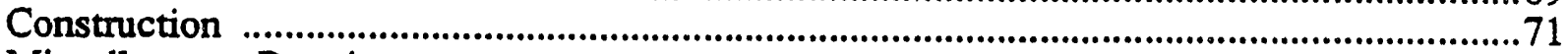

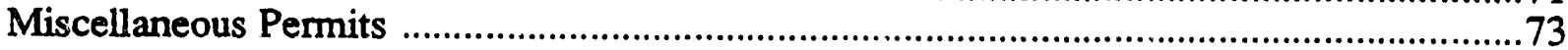

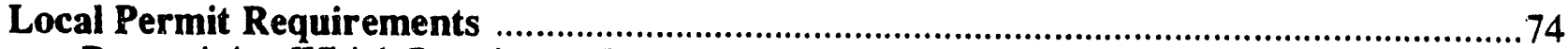

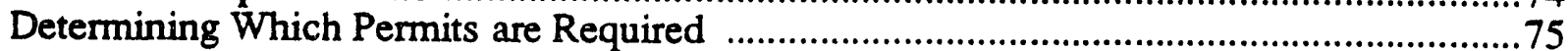

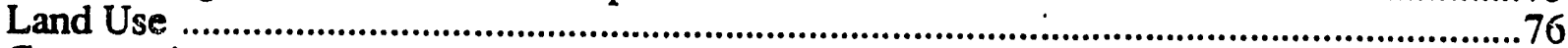

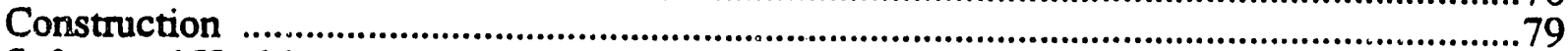

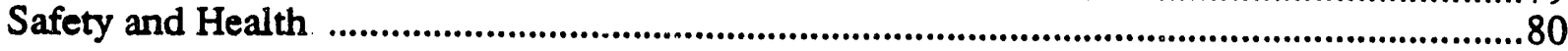




\section{Permit Summary Sheet - Montana ............................................................}

Chapter 3 - The Montana State Process …………………………....82

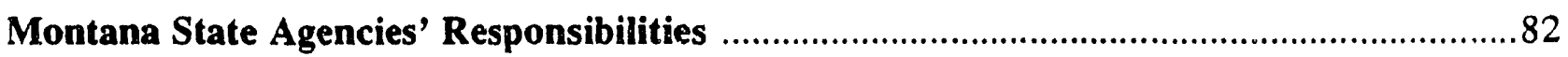

Montana Permitting and Licensing Requirements .............................................................8

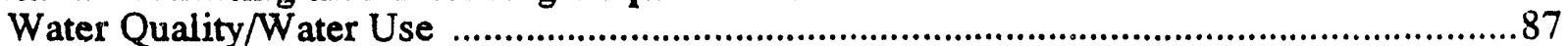

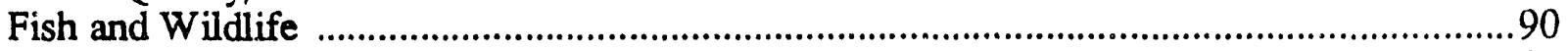

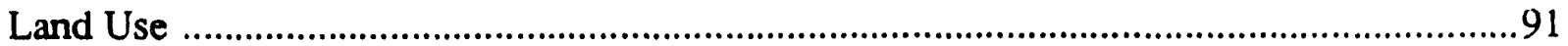

Construction ......................................................................................................................93

Miscellaneous Permits .................................................................................................................94

Local Permitting and Licensing Requirements .....................................................................97

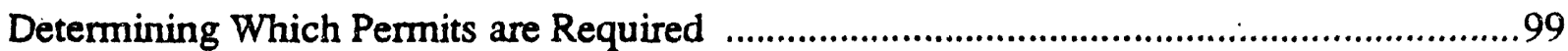

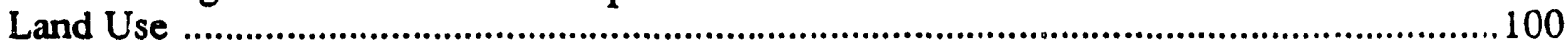

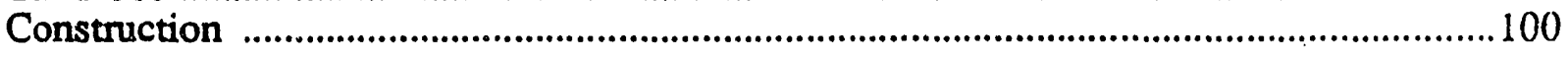

Permit Summary Sheet — Oregon ...........................................................103

Chapter 4 - The Oregon State Process ..................................................104

Standards for Siting Hydroelectric Projects .....................................................................104

Process for Submitting Applications ................................................................................. 106

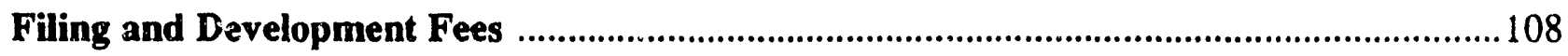

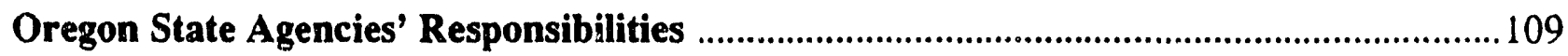

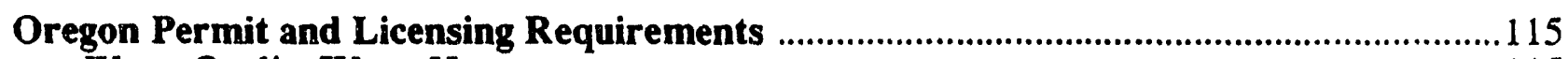

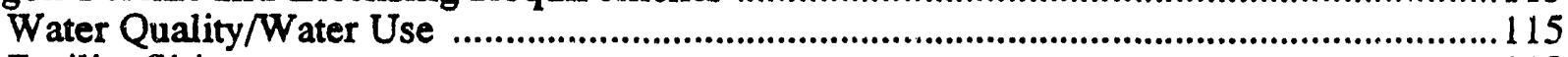

Facility Siting ………...........................................................................................................119

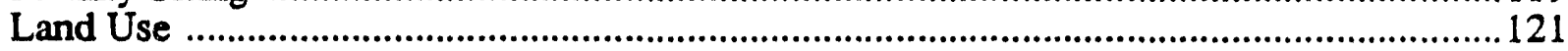

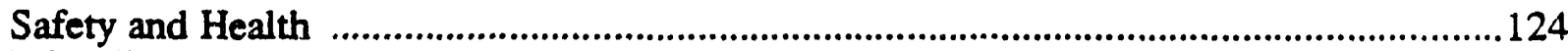

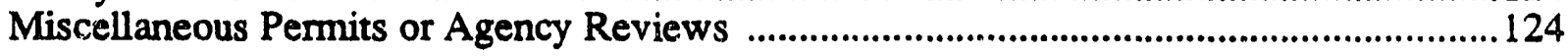

Local Permitting and Licensing Requirements .............................................................126

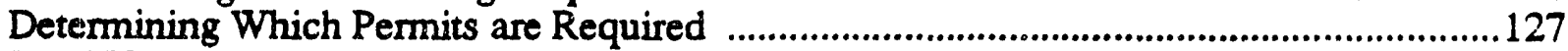

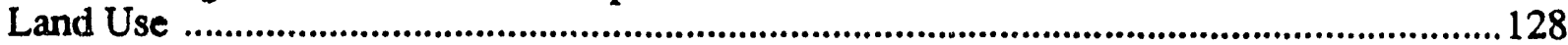

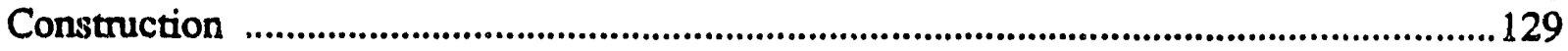

Permit Summary Sheet — Washington ..............................................131

Chapter 5 - The Washington State Process ……………………...132

Washington State Agencies' Responsibilities ..................................................................132

Washington State Permitting and Licensing Requirements ...........................................141

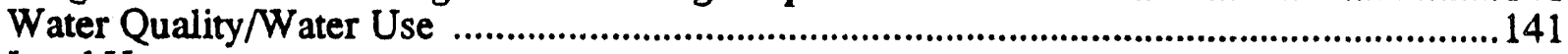

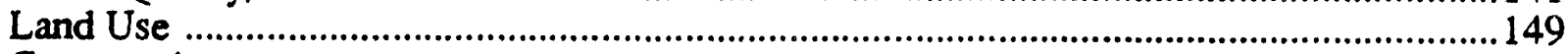

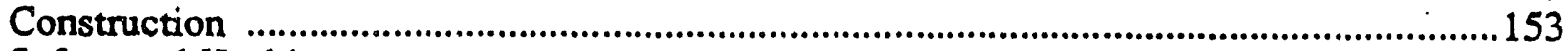

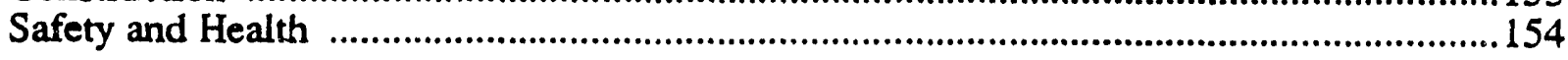

Local Permitting and Licensing Requirements ..............................................................156

Determining Which Permits are Required ..............................................................158

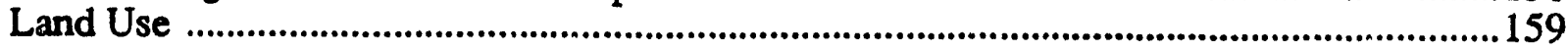




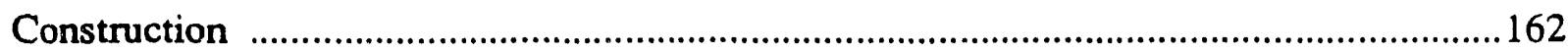

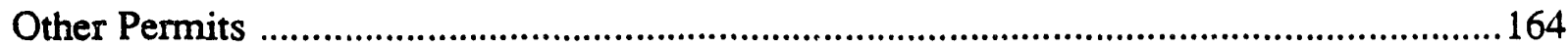

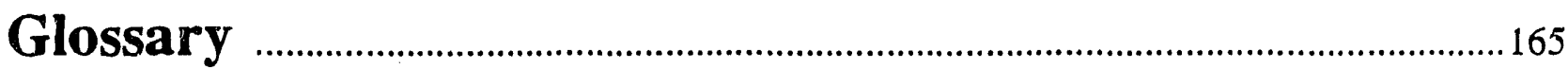

Appendices

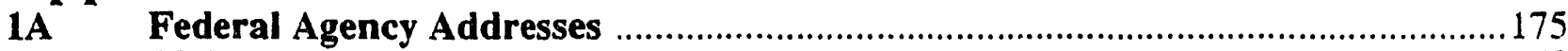

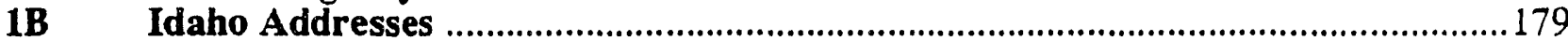

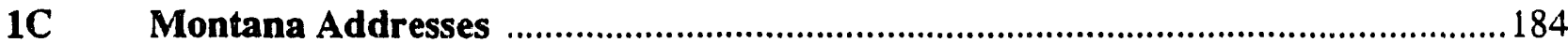

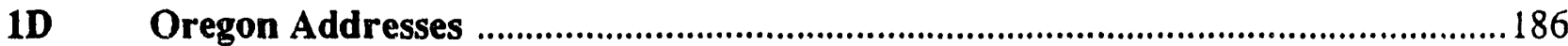

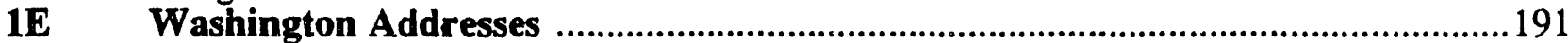

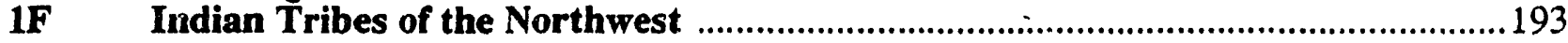




\section{Listing of Tables}

1. Potential Environmental Impacts Associated with Small Hydroelectric

Project Development

2. Studies or Actions Which May be Required to Assess Impacts and Concerns

Associated with Small Hydropower Project Development .........................................21

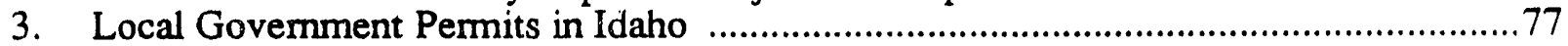

4. Designated Resource Areas in Oregon ...............................................................106

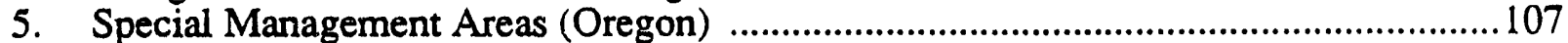

6. Public and Private Agencies (Oregon) ....................................................................... 107

7. NPDES Permit Application Forms (Oregon) ..................................................118

8. Titles of LCDC Statewide Planning Goals (Oregon) ...........................................121

9. When to Submit Land Use Compatibility Statements (Oregon) ................................124

10. Industrial and Commercial Noise Source Standards (Oregon) ...............................124

11. Industrial and Commercial Noise Source Standards for Quiet Areas (Oregon) ..........126

12. Median Octave Band Standards for Industrial and Commercial

Noise Sources (Oregon)

13. Possible State Permits or Evaluations Required for Development of a Hydroelectric Project in Washington

14. Typical Local Permit Requirements-Washington State

\section{Listing of Figures}

1. Idaho Designated Protected Lands

2. National Parks and Wilderness Areas in Montana ..............................................

3. Wilderness Areas, National Parks, and National Monuments Within Washington .........9

4. Idaho: Wild and Scenic River Designation ...............................................................10

5. Federally Designated Wild and Scenic Rivers in Oregon ...........................................11

6. State of Washington-Wild and Scenic Rivers ..................................................12

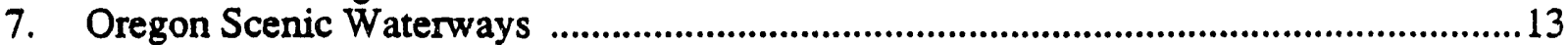

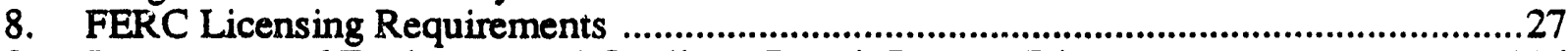

9. Department of Environmental Quality-Permit Process Diagram ...............................116

10. Calendar for Timing Typical Permits Minimum Time You Can

Expect Before Approval

11. Energy Facility Siting Council Application Process Diagram ..................................120

12. Local Govemment Land Use Approval Land Use Planning and Permit Process ........122

13. Building Codes Agency-Building Permit Process (Oregon) ..................................125

14. Washington State Department of Ecology Involvement in the Hydroelectric Project Permitting Process

15. Washington's SEPA Process .

16. Washington State Department of Ecology Involvement in Granting a

Water Rights Certificate

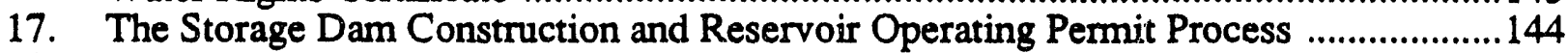

18. The Water Quality Certification Process (Washington) ...........................................147

19. The Flood Control Zone Variance Process (Washington) ...........................................148

20. The Hydraulic Project Approval Process (Washington) ............................................150

21. Washington Department of Ecology's Involvement in the

Shoreline Management Permitting Process 


\section{Introduction}

The design, construction, and operation of a hydropower project can result in many potential impacts. These potential impacts are of concern to a host of federal, state, and local authorities. Early consultation with land and water management, fish and wildlife resource protection, and health and human safety-oriented agencies should occur to determine specific concerns and study requirements for each proposed project.

This Guide to Permitting and Licensing outlines the characteristic features of attractive hydropower sites; summarizes an array of developmental constraints; illustrates potential environmental impacts and concerns; and summarizes all federal, state, and local permitting and licensing requirements.

\section{Resource Characterization and Development Constraints}

\section{Features of Attractive Hydropower Sites}

A good small scale hydroelectric site is characterized by a number of factors including:

- high head

- streamflow availability

- lack of migratory or resident fish

- no threatened or endangered species present

- does not involve critical wildlife habitat

- presence of project features such as diversion structures

- existing access roads

- proximity to utility transmission lines or point of electricity end use

- site not used for recreation or known for its aesthetic values

- stable terrain

- land ownership

\section{High-Head}

High-head hydropower sites tend to be more cost effective than low-head sites. Projects with greater than 20 meters or 66 feet of available drop are generally considered to be high-head sites. The conventional wisdom in the Northwest is that sites with heads less than 16 feet, deemed "ultra low" head sites, are scarcely worth examining. The reason that high head sites are preferred is obvious from the equation yielding the installed project capacity from the design head and flow conditions. 


$$
\mathrm{kW}=\frac{\mathrm{H} \cdot \mathrm{Q} \cdot \mathrm{W} \cdot \mathrm{N}_{\mathrm{t}} \cdot \mathrm{N}_{\mathrm{g}} \cdot \mathrm{K}}{550}
$$

Where $\quad \mathrm{kW}=$ installed generating capacity, $\mathrm{kW}$

$\mathrm{H}=$ effective head, feet

$\mathrm{Q}=$ design hydraulic capability, cfs

$\mathrm{W}=$ weight of water per cubic foot

$N_{t}=$ turbine efficiency

$\mathrm{N}_{\mathbf{g}}=$ generator efficiency

$\mathrm{K}=$ conversion from $\mathrm{hp}$ to $\mathrm{kW}, 0.746$

$550=\mathrm{ft}-\mathrm{lb} / \mathrm{sec}$ per hp

As seen from Equation 1, the project generating capacity is proportional to the product of the net head and design streamflow. Thus, for a given project output, a site with 200 feet of available head requires only 10 percent of the water used at a site with 20 feet of head. The economic advantages are that a smaller diameter pipeline and a smaller water turbine may be used with the reduced flow volume. High-head water turbines have significantly reduced installed costs (in $\$(\mathbf{k W})$ as compared with low-head sites.

\section{Streamflow Availability}

Streamflow availability refers to several factors including seasonality of stream discharge, prior allocation of waters, and the need to establish minimum instream flow requirements. Sites with uniform flow conditions such as spring fed streams, wastewater treatment plant outfalls, and industrial or municipal water supply lines are ideal in that high capacity factors can be realized with dependable year to year energy and revenue production. Many sites exhibit a fairly uniform discharge due to fall and winter rains, and spring snowmelt. Glacial fed streams also show good runoff during the late summer when other streams are experiencing seasonal low flow conditions.

Obviously, waters for which consumptive rights have already been issued may not be available for hydropower purposes. The hydropower developer must be aware of reserved rights and consumptive withdrawals both upstream and downstream of the project site. The developer should consult with the appropriate state regulatory agency to determine if water has been appropriated prior to the gathering of streamflow data. Waters that are reserved for meeting minimum instream flow requirements are also not available for run-of-river power production.

\section{Lack of Migratory Fish}

Power houses for high-head, run-of-the-river projects are frequently located at or above the base of the first impassible barrier to the passage of migratory fish. With this practice, impacts on salmon and steelhead fishery resources are minimized. 
Environmental disruption is further minimized and the licensing process facilitated for projects located at the site of existing dams, irrigation water conveyances, or water supply pipelines. Developers of such projects are eligible to apply for the existing Federal Energy Regulatory Commission (FERC) "case-by-case" or "conduit" exemptions from the federal hydroelectric project licensing process.

\section{Existing Access Roads and Proximity to Utility Transmission Lines}

Hydroelectric project development costs may be significantly reduced given the presence of access roads to the project intake and power house sites. Pressure penstock installation costs and environmental impacts may be reduced by routing the pipeline along existing roads, trails, or power line right-of-ways.

Development costs and environmental damages are greatly reduced given the presence of threephase utility distribution power lines of compatible voltage near the vicinity of the powerhouse. A project must be of considerable size to justify the transformation costs associated with interconnecting with higher voltage utility transmission lines.

\section{Developmental Constraints}

regional, state, local, and federal government agencies play a substantial role in the siting, design, and operation of hydro projects to protect society and the environment from the potential impacts of hydro development. Limits are placed on where a project may be built; environmental mitigation facilities that must be constructed are defined; and restrictions are imposed on project operations. While many of the permits described elsewhere in this document involve environmental protection as one of their purposes, certain key environmental considerations in the siting, design, and operational aspects of a hydro project are specifically described below.

\section{Protected Areas}

On August 10, 1988, the Northwest Power Planning Council adopted a proposal to designate some 44,000 miles of Northwest streams as "protected areas" because of their importance as critical fish and wildlife habitat. Hydroelectric development will not be allowed to proceed in areas with highly valued fish and wildlife resources or critical habitat.

The "protected areas" amendment is a major step in the Council's efforts to rebuild fish and wildlife populations that have been damaged by hydroelectric development. Low cost hydroelectric power has provided tremendous benefits to the Northwest, but those benefits have imposed significant costs. The Northwest's fish and wildlife populations have suffered extensive losses-salmon and steelhead runs in the Columbia River drainage are of a fraction of their former numbers. The Council's goal of doubling salmon and steelhead runs in the Columbia River Basin will require hardy wild and natural fish populations, which in turn rely on high quality habitat. To protect the ratepayers' investment in fish and wildlife restoration, it is necessary to protect the best remaining habitat. 
The Council identified areas to be protected after conducting extensive studies of fish and wildlife, and of their spawning grounds and habitat in the region. The Council then analyzed alternative means to protect them from further degradation. The Council concluded: 1) the studies have identified fish and wildlife resources that are of critical importance to the region; 2) mitigation techniques cannot assure that all adverse impacts of hydroelectric development on these fish and wildlife can be eliminated; 3) even small hydroelectric projects may have unacceptable individual and cumulative impacts on these resources; 4) because of the likely cost and difficulty of developing hydroelectric projects in protected areas, the Council considers them unlikely to be reliable and available within the time needed, for purposes of cost effectiveness determinations under the Northwest Power Act; and 5) protecting these resources and habitats from hydroelectric development is consistent with an adequate, efficient, economical, and reliable power supply.

The Council has established several goals that it hopes to achieve through these protected area designations:

1. To protect the critical fish and wildlife habitat that remains;

2. To avoid expensive and divisive disputes over hydropower development in sensitive fish and wildlife areas;

3. To reduce costs and uncertainties in the region's ability to meet its power needs at least cost:

4. To help ensure tha substantial ratepayer investments in fish and wildlife in the Columbia River Basin would not be undermined;

5. To provide clearer signals to potential developers on the importance of fish and wildlife resources and to help developers focus their attention on less sensitive areas for development;

6. To provide useful information to the Federal Energy Regulatory Commission so that its hydiropower decisions will reflect the region's interest in quality resource development and environmental protection.

Guidelines for protected areas include:

1. Protecting all areas currently or potentially used by anadromous (ocean-migrating) fish in the Columbia River Basin;

2. Protecting all areas currently used by anadromous fish outside the Columbia River Basin;

3. Preserving high-quality resident fish and wildlife habitat both inside and outside the Columbia River Basin; 
The Council adopted a single standard of protection stating no new hydroelectric development should be allowed in protected areas.

The protected area restrictions do not apply to:

1. Any hydroelectric facility or its existing impoundment that had as of August 10,1988, been licensed or exempted from licensing by the Federal Energy Regulatory Commission

2. The relicensing of such hydroelectric facility or its existing impoundment

3. Any modification of an existing hydroelectric facility or its existing impoundment

4. Any addition of hydroelectric generation facilities to a non-hydroelectric dam or diversion structure

The Council derives its authority from the Northwest Power Act of 1980 (PL 96-501), which required the Council to develop a program to "protect, mitigate, and enhance fish and wildlife, including related spawning grounds and habitat" that had been affected by hydroelectric development in the Columbia River Basin.

The Council designated protected areas in the Columbia River Basin under the authority of Section 4(h) of the Northwest Power Act, which deals with the Columbia River Basin Fish and Wildlife Program, and in other parts of the region under the authority of 4(e) of the Act, dealing with the regional power plan.

The final protected areas proposal, as adopted, is a formal amendment to both the Council's Columbia River Basin Fish and Wildlife Program, which covers the Columbia Basin, and to the Northwest Power Plan, which covers the entire states of Idaho, Oregon, Washington, and western Montana.

\section{Land Use Constraints}

Development of any hydropower project requires obtaining ownership and securing leases, easements, rights-of-way, or other approvals to occupy and use affected land and water. There are several areas where construction of a hydropower project is precluded, prohibited by law, or severely regulated.

\section{Wilderness Areas, National Parks, and National Monuments}

Federally designated areas where hydro development is restricted include Wilderness Areas, National Parks, and National Monuments. Passage of the Washington State Wilderness Bill, S. 837, added one million acres to the National Wilderness Preservation System in Washington Staxe. In 1982 the Mount St. Helens National Monument Area was established for the protection of unique geologic, ecologic, and cultural resources. The National Park System provides protection of recreational and environmental resources of the United States. The U.S. Forest Service 
should be contacted to determine the exact ownership and status of land within the boundaries of a proposed hydropower site. Wilderness areas, national parks, and national monuments within Idaho, Montana, Oregon, and Washington are shown in Figures 1-3.

\section{Wild and Scenic Rivers - Federal}

Under the Wild and Scenic Rivers Act of 1968, the Federal Energy Regulatory Commission (FERC) is barred from licensing projects on, or directly affecting, any component of the National Wild and Scenic River System. This includes not only "designated" wild and scenic rivers, but also "study" rivers as enacted by Congress under section 5(a) of the Act. In addition, a federal agency cannot make a loan or provide assistance for a project on these rivers without assurance that the project will not adversely affect the river's special values.

In addition to Congressionally designated rivers, rivers may be administratively listed as "potential" wild and scenic rivers under section 5(d) of the Act. Designated, potential, and study wild and scenic rivers within Idaho, Oregon, and Washington are depicted in Figures 4 though 6. Oregon, as established under Ballot Measure 7 Scenic Waterways, are indicated in Figure 7.

All federal actions (e.g., FERC licensing) having an adverse impact on designated or potential wild and scenic rivers must be coordinated with the National Park Service. "Potential" scenic river status does not automatically preclude hydro development, but it requires the prospective developer to evaluate the river for wild, scenic, and recreational values, and to report these findings to FERC as part of the license application.

\section{Historic and Archaeologic Sites}

Projects affecting historic or archaeological sites on federally owned or controlled lands must be approved by the Secretary of the Interior through the National Park Service. FERC must evaluate the effect of a project on a site and negotiate agreements on methods of impact avoidance or mitigation with the Executive Director of the Advisory Council on Historic Preservation and the State Historic Preservation Officer. Check the National Registration List to see if the site qualifies or is already listed.

\section{Fish Protection and Mitigation Requirements}

Even where no land use restrictions or protected areas exist, fish screens must be installed on a hydroelectric project's intake structure to prevent the passage of resident or migrating fish through the water turbines. The federal and state resources agencies prescribe the screen mesh size and allowable flow approach velocity depending upon the type and life stage of fish present. The agencies may require that upstream as well as downstream fish passage be allowed. 


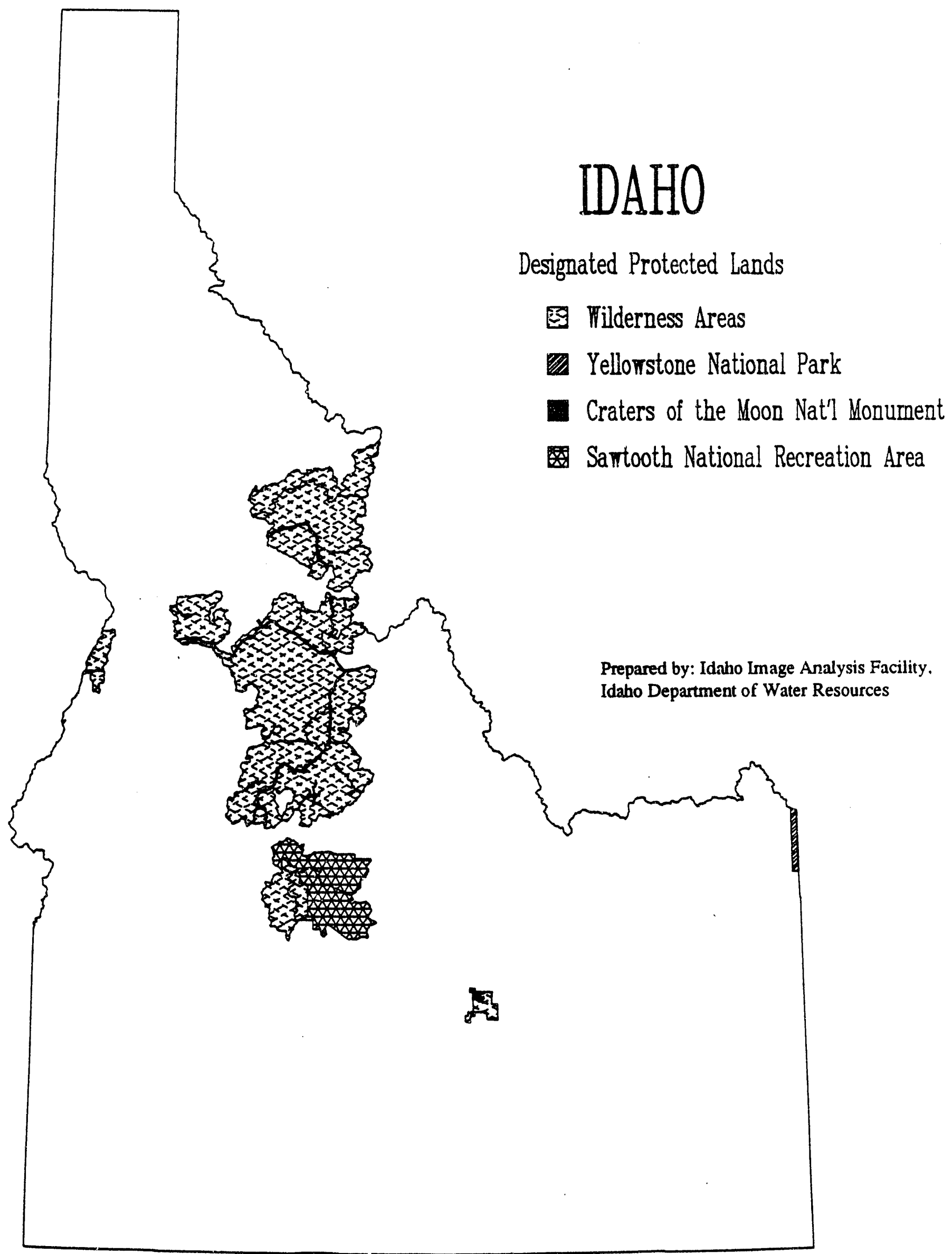

Figure 1: Idaho Designated Protected Lands 


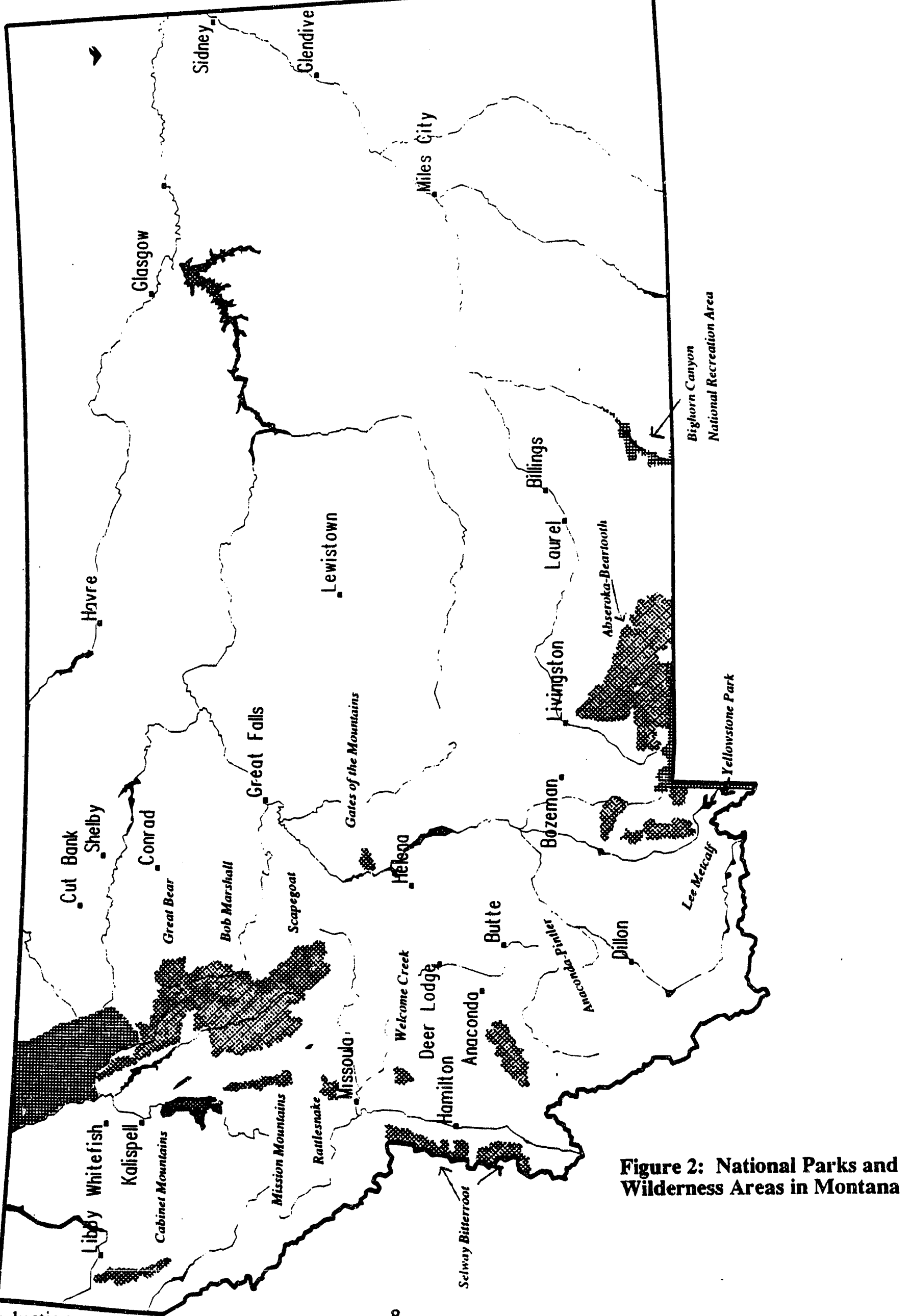




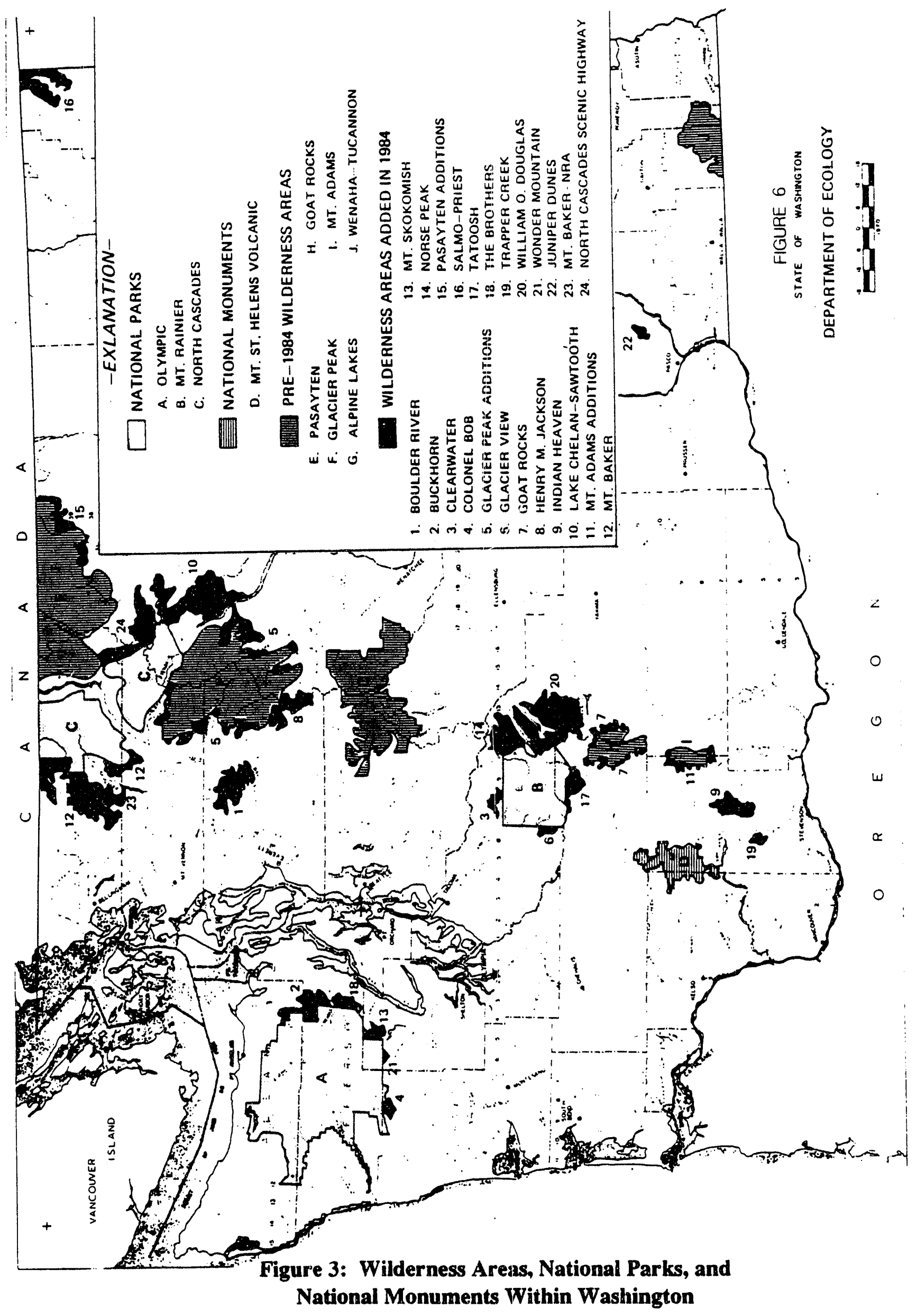




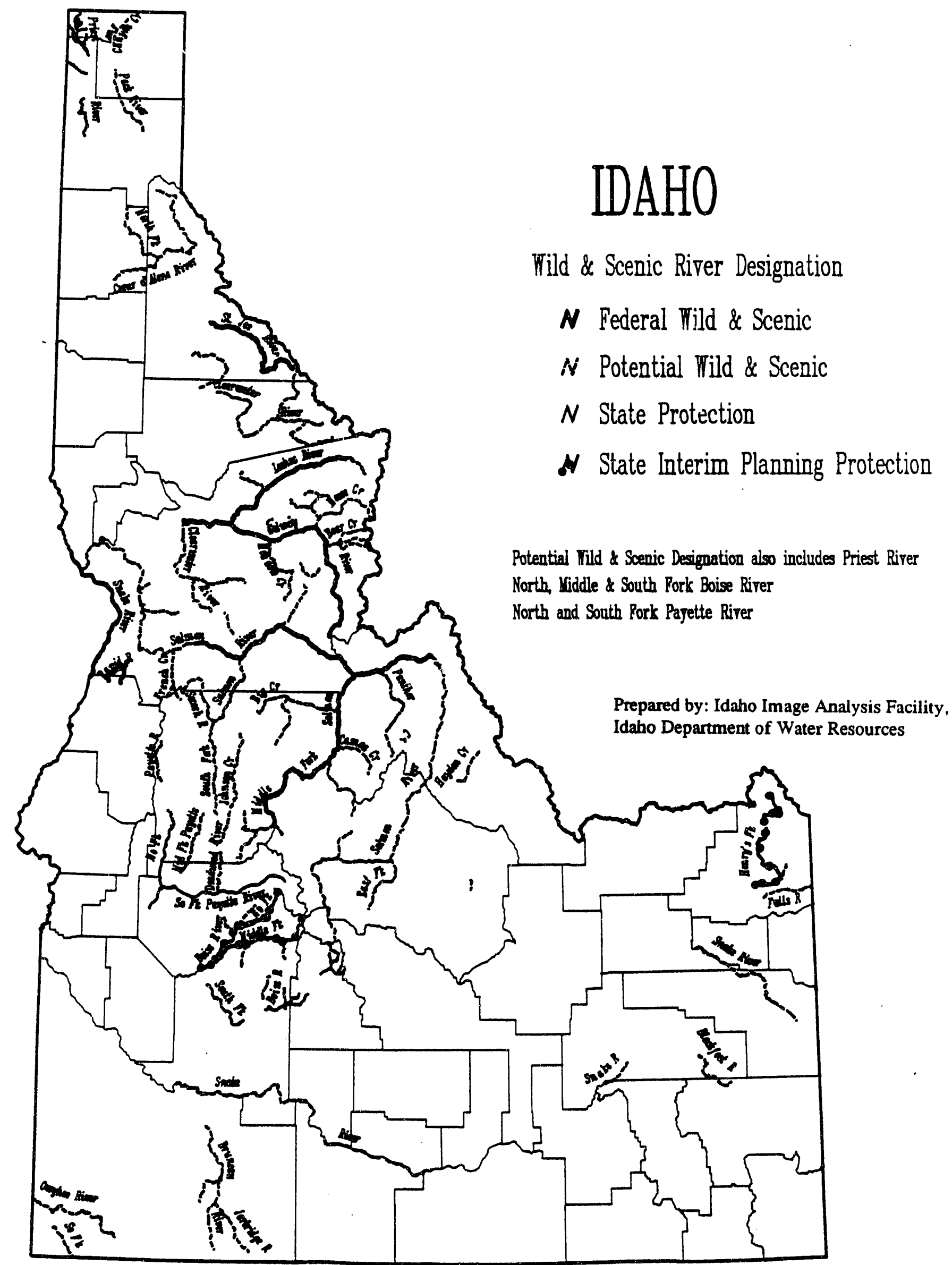

Figure 4: Idaho: Wild and Scenic River Designation 


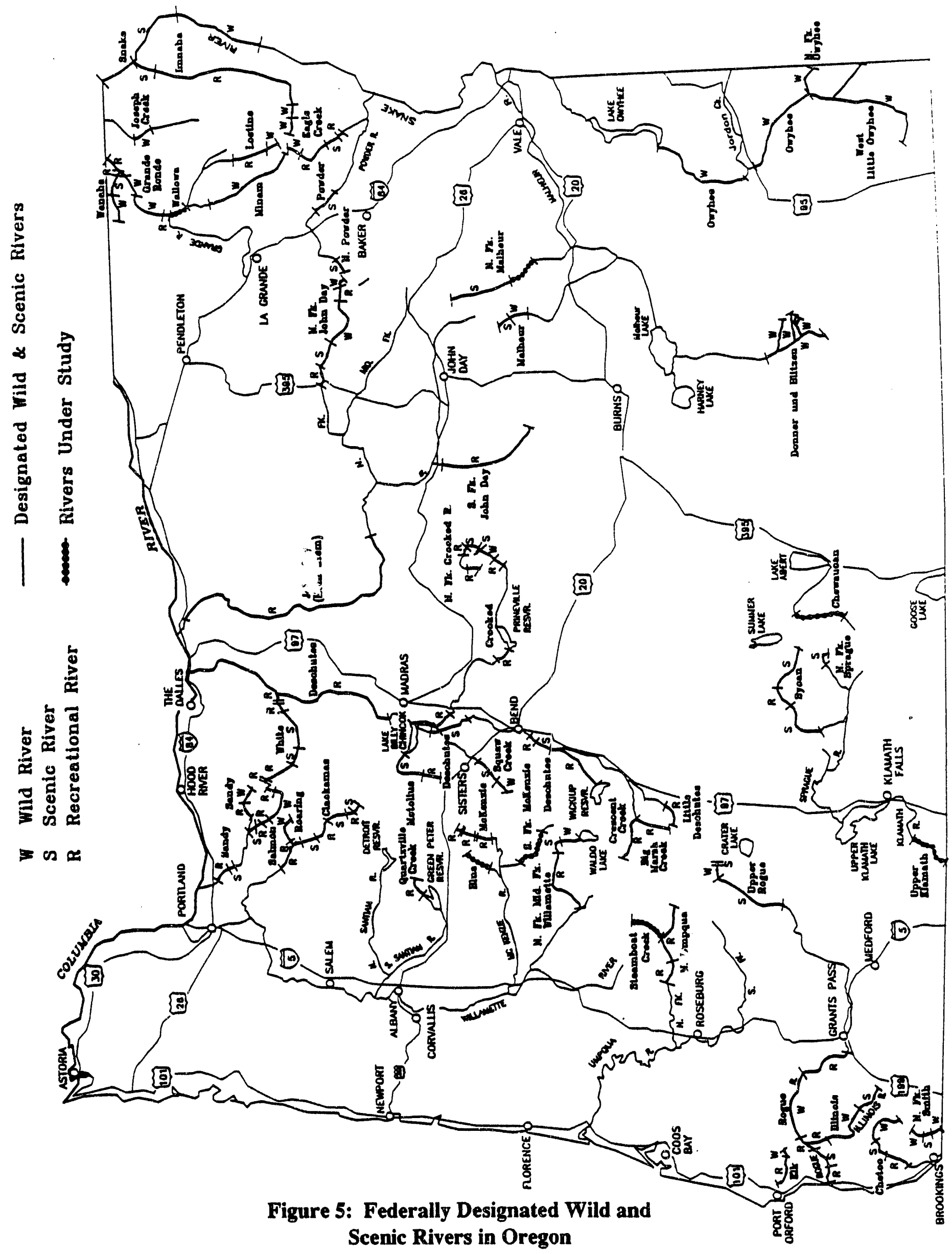




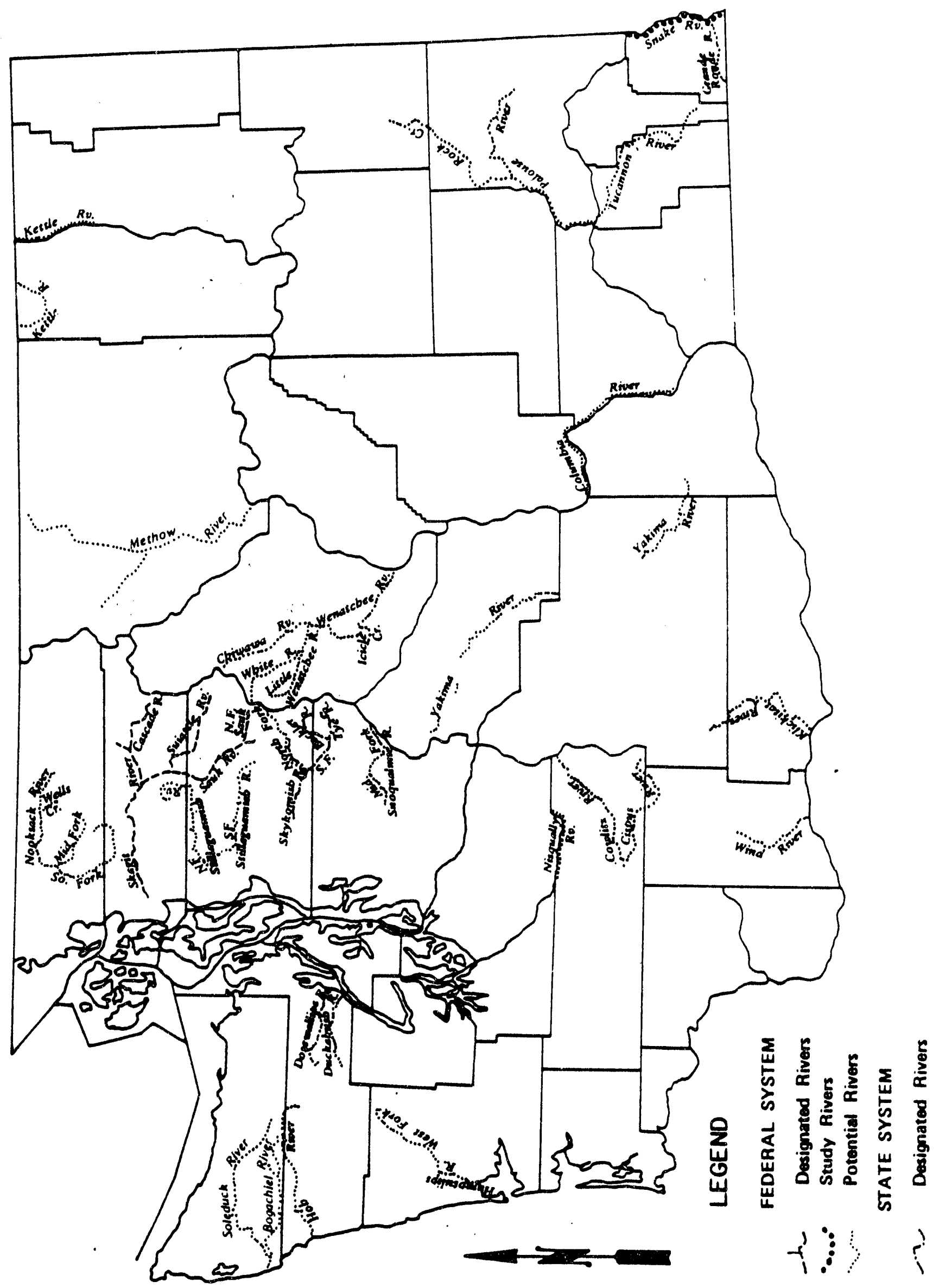

Figure 6: State of Washington-Wild and Scenic Rivers 


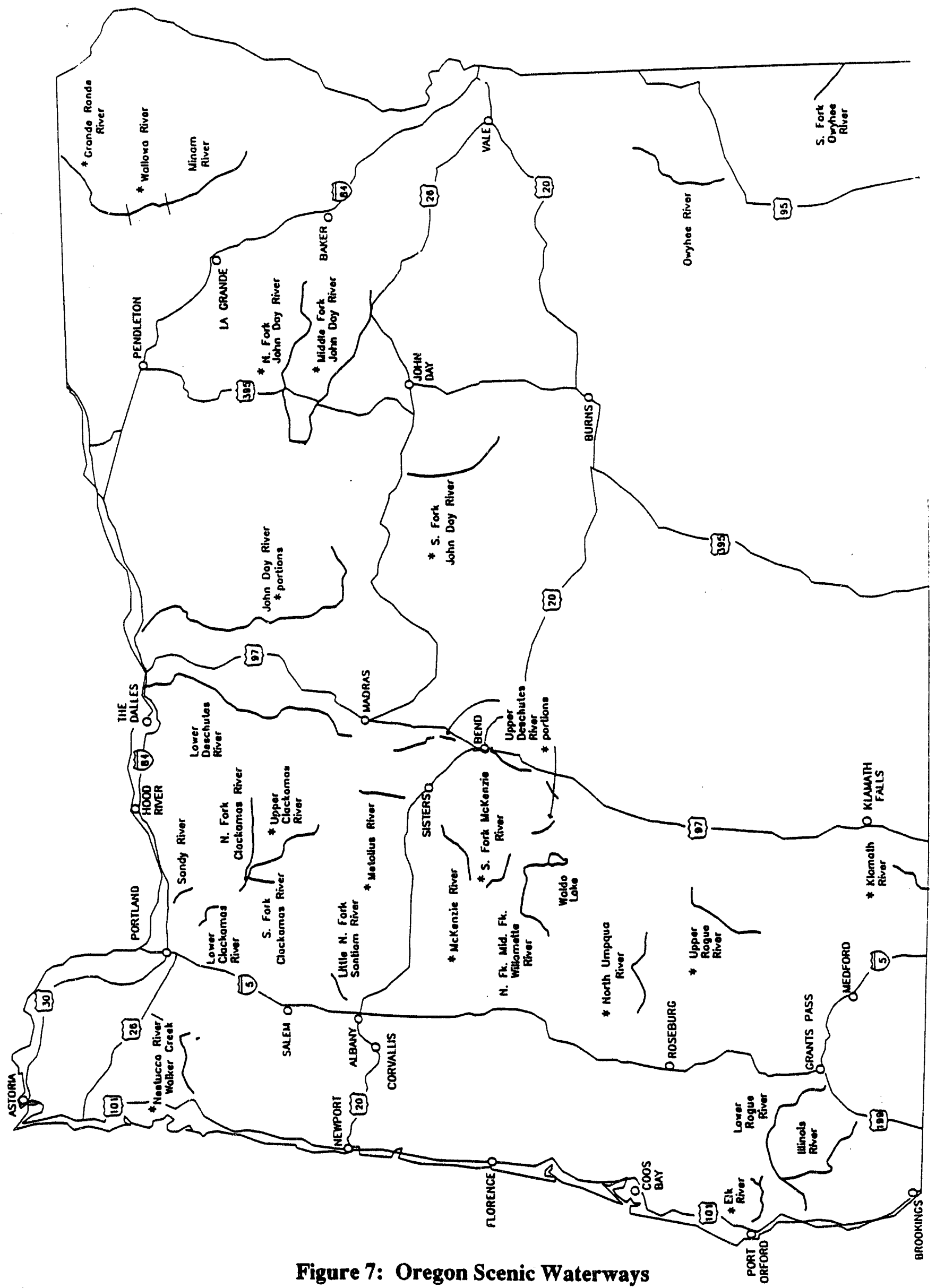

Introduction 
The resource agencies aitditionally require that a minimum instream flow be released at the diversion point, if naturally available, to maintain instream qualities and fish and wildlife habitat in the stream reach that is bypassed. The instream flow established is designed to maximize available habitat by providing water depths and flow velocities that are conducive to fish spawning, incubation, rearing, and migration. Instream flows are established following the use and interpretation of an acceptable analytical methodology such as the Instream Flow Incremental Method (IFIM).

It is also required that the intake structure and diversion dam be designed to allow a natural downstream movement of bed load materials. This ensures that the spawning gravel composition below the diversion dam will remain unchanged from pre-project conditions. It also eliminates the need to periodically flush and/or dredge the reservoir pool and project forebay. An automatic shut-off valve must be installed in the diversion structure to discontinue water withdrawals in the event of a penstock rupture. This provision prevents soil erosion or hillside slumping in a breakage area.

In order to prevent stranding of migratory or resident fish, the resource agencies typically require that a ramping rate, or gradual rate of increase or decrease in powerhouse discharge be established prior to project operation. A bypass or flow continuation valve, which automatically passes waterflows around the turbine in the event of load rejection, is often required to maintain a uniform powerhouse discharge.

The intake system must also be designed to avoid air entrainment. Anti-vortexing devices, adequate water cover, and air vents may be used to accomplish this purpose. The elimination of air entrapment minimizes the possibility of nitrogen supersaturation in the project's discharge waters. Dissolved gases must be allowed to reach equilibrium before the discharge water reenters the stream.

Often, discharge velocity dissipation structures must be incorporated into the tail race design to lessen the possibility of erosion or destruction of aquatic habitat during load rejection or turbine maintenance periods. If the project tailrace is in an anadromous or migratory fish zone, it must be racked or screened to prevent the entrance of adult salmon. Projects that are designed to divert water from one stream to another are discouraged, as the displacement of water affects the homing of adult salmon.

As stream siltation can reduce spawning gravel quality and degrade rearing habitat in aquatic areas impacted by construction of the powerhouse, intake, pipeline, and transmission line, project timing and construction restrictions may be imposed. An erosion control plan indicating responses and mitigation features during project construction, maintenance, emergency, and abandonment phases must be prepared. The plan should contain specific mitigation measures for the treatment and rehabilitation of construction areas.

Project proponents must be aware of possible wildlife, as well as fishery impacts. Resource agencies are concemed about the displacement of forest habitat with project features. Penstock 
routing must allow for the movement of wildlife either over or under the pipeline at short intervals. Migratory birds and raptors must be protected by construction timing restrictions and proper power line and pole design. Consultation with the appropriate resource agencies should ensure that no listed or proposed threatened or endangered species would be negatively affected by project construction, maintenance, or operation.

\section{Dam and Pipeline Safety Concerns}

To ensure that a hydro facility will not present a danger to life, property, or environmental quality, state regulators may examine project specifications for structural characteristics and design, potential erosion and sedimentation, materials strength, structural geology of the diversion site, and penstock bedding and anchoring. Besides the significant concerns for public safety and fisheries resources, plans should also consider aesthetics, water quality, and emergency procedures.

Examples of specific measures that can be taken are an automatic bypass valve or deflector wheel will ensure a continued flow of water, and a controlled ramping rate during a load rejection. The automatic shut-off valve will reduce possible damage from erosion and sedimentation.

\section{Potential Environmental Impacts and Concerns}

Potential environmental effects are associated with all components of a hydroelectric project including the diversion dam, a reservoir if one exists, the penstock, powerhouse, access roads, and transmission corridors. Impacts are likely to arise from the construction of these facilities as well as from their operation and maintenance. All impacts must be considered both at the project site and downstream. Environmental impacts are highly site- and design-specific, a particular design that is optimal for one site from an environmental standpoint may be very destructive at another site. For a given site, impacts will depend substantially on the size and type of the project as well as its specific design configuration.

Although it is difficult to rank the environmental acceptability of various types of hydropower configurations in general terms, resource agencies generally agree that projects involving an existing dam (or, for small projects, no dam at all) will have fewer adverse impacts than projects requiring construction of a new dam. Similarly, run-of-river and diversion type projects (assuming maintenance of adequate instream flows for diversion projects) will generally be more environmentally acceptable than projects involving a storage reservoir.

While it is not possible to accurately predict the environmental impacts of a particular hydro project without site- and facility-specific information, it is possible to list the potential impacts of hydro projects. The following paragraphs describe a few of the key environmental concems that must be considered by the potential hydropower developer. 


\section{Run-of-River Projects}

Many Northwest hydroelectric facilities are small-scale run-of-river projects that utilize highgradient streams to produce electricity. Most proposals involve a low diversion structure within the stream-bed and use a pipeline, canal, and/or pressure penstock to convey water to a powerhouse. Once the water is used to generate electricity it is retumed to the stream, downstream from the diversion point. Few projects involve a new storage dam or a larger impoundment structure to divert the necessary flows and create the hydraulic head needed to produce energy. Other projects use existing dams and/or conduits.

The design phase of a proposed hydroelectric project is the best time to anticipate potential environmental impacts from the construction or operation of the project. Very often, the most basic characteristics of the project such as the size, design, and location determine the potential for environmental impact.

Any structure built within a stream channel has the potential to impede movement of aquatic organisms and sediment. This can be especially harmful to anadromous fish that rely on stream habitat for spawning, incubation, and rearing. An improperly designed or operated facility can cause significant mortality to juvenile fish migrating downstream and to adult fish migrating upstream to spawn.

A diversion structure can cause mortality of fish at the intake if velocities are such that the fish become trapped at the intake screen. If no screen exists, the fish may go through the water turbines, usually with high mortality rates. A poorly designed intake structure may cause entrainment of air, resulting in high dissolved gas levels in the water released from the powerhouse site. This nitrogen supersaturation can cause a fatal condition in fish similar to "the bends."

Because of the potentially serious safety and environmental hazards that accompany above and below ground pipelines and penstocks, proper design of these facilities is particularly important. Pipeline, canal, or penstock leakage can destabilize slopes and lead to pipe failure, land slides, or other mass wastage of slopes. Resulting erosion can drastically affect stream productivity. Public safety may also be affected in downslope or downstream areas. Contingency planning is important as well as the incorporation of leak detection and automatic shut-off mechanisms.

Construction of a dam or diversion structure presents considerable potential for adverse environmental impact. Erosion and bed load (sediment) increases can occur when clearing the stream bank, blasting underlying bedrock, or during construction within the stream channel. Standards for water quality must be met during all phases of construction. Harmful impacts to fish and wildlife must be avoided by working within the stream channels during low flow periods. Clearing and revegetation for the project facilities, pipelines, transmission line right-of-ways, and access roads can affect wildlife in the area. The use of proven methods of construction and careful scheduling can greatly reduce environmental impacts during this phase of the project. 
Operation of any hydro facility has the potential to adversely impact the stream's natural resources. Insufficient instream flows through a bypass reach will affect fish and wildlife habitat, water quality, recreation, scenic and aesthetic values, navigation, and other environmental values. Decreases in instream flows can reduce fish habitat and aquatic productivity. In some cases, barriers that were insignificant under natural flows can become impassible to migrating fish. When carried out too rapidly, project startup can cause dewatering of a bypass reach, stranding fish and creating a surge of water below the powerhouse, causing erosion, sediment transfer, and fish and wildlife habitat damage. Conversely, a sudden shutdown will cause a surge of water in the bypass reach and dewatering below the powerhouse. Ramping rate (rate of change in flow) limitations are necessary to avoid these impacts.

Fisheries resources can be affected by water discharging from the powerhouse tailrace. Fastmoving water will attract fish migrating upstream. Migration behavior may be impaired when changed water flow patterns fail to provide proper orientation cues. Delays of fish at these false attraction sites can reduce subsequent spawning success due to. depletion of stored energy reserves. Proper location and design of the tailrace can reduce or eliminate this problem.

Projects on streams with high bedloads or suspended sedimeni loads may accumulate large amounts of material in the pool formed by a diversion structure. Sufficient material may be collected that the diversion of water is impaired. Occasional cleaning by dredging or sluicing may be necessary. These activities can affect water quality and must be scheduled to minimize effects on fish and downstream water quality.

\section{Reservoir Projects}

Only a few large reservoir projects have been proposed for non-federal development in recent years. These projects can cause significant environmental impacts of a different nature. A reservoir is characterized by reduced water velocity, which may result in changes in water temperature, dissolved oxygen levels, turbidity, water chemistry, and aquatic habitat. In deep reservoirs, thermal and chemical stratification is likely to occur with potentially significant effects on the biota in and downstream of the reservoir. Downstream effects can be beneficial or adverse, depending on the site and facility design.

In general, creation of a reservoir transforms an ecosystem dependent on moving water into one dependent on still water. This results in substantial changes in the distribution, abundance, and diversity of organisms and in the carrying capacity of the habitat.

Creation of a reservoir may also flood valuable natural or manmade objects. These include roads; utilities; buildings; sites of historic, cultural, archaeologic, or scientific interest; productive farm or forest land; terrestrial, riparian, and stream-dependent habitat; and free flowing/whitewater streams, waterfalls, and associated recreation areas. Creation of a reservoir may attract new shoreline development, thus introducing a wide range of secondary environmental impacts associated with such activities. New recreation opportunities are often created that displace ex- 
isting recreational activities associated with free-flowing streams and natural environment. In some cases, valuable flatwater recreation areas and new lake-type aquatic habitat are created by hydro projects, but reservoir fluctuations may limit these favorable factors. The scenic value of the site is usually altered and sometimes impaired.

Operation and maintenance of a reservoir project is also not without potential problems. The operation of a reservoir hydroelectric project generally results in large changes in reservoir level. Fluctuations may be daily, seasonal, or both. Alteration in the natural flow regime can be detrimental to downstream aquatic life forms and recreation. The drawdown zone is typically unattractive, biologically unproductive, and subject to erosion. Water quality may be affected by the decay of flooded organic matter and the release of soil chemicals into the water. Reduced water velocity causes the streams' natural sediment load (together with associated nutrients and other chemicals) to be trapped in the reservoir. The channel downstream may be degraded over time by the reduction in bed load transport.

If a project is carefully designed, constructed, and operated, minimum adverse impacts are likely to occur. Early contact with resource agencies is strongly advised so that impacts can be identified and mitigated at the pre-design stage.

\section{Potential Study Requirements and Impact Assessment Actions}

Potential impacts of hydropower projects may be of concern to one or more state or federal administrative, resource, or land management agencies. Early consultation with each of the interested agencies should occur to determine specific concerns and study requirements on each project. A list of typical concerns associated with a small hydropower development is given in Table 1.

General study requirements or actions are outlined in Table 2. Table 2 is organized to match the outline of potential impacts and concerns.

Individual agencies will require different combinations of studies according to their areas of jurisdiction. Proposed study plans should be coordinated with all agencies concerned. Joint interagency and applicant meetings are beneficial and may be required for some studies. As a general guideline, all phases of environmental assessment and project development should be coordinated with the appropriate land management agency when public lands are involved and the appropriate Indian tribe when reservation, ceded lands, and usual and accustomed places are involved. All phases of fish and wildlife resource impact assessment should be coordinated with the appropriate federal and state resource protection agencies. 


\section{Table 1}

Potential Environmental Impacts Associated With Small Hydroelectric Project Development

Impact issues of general public interest

Use/encumbrance of public lands

Need for project power

Economic impact of projects

Public safety, dam safety, fire hazards

Project technical and economic feasibility

Cultural, archaeological, and historical resources

Applicant's financial capability

Project interaction/compatibility with other activities

Timber production

Grazing or range management

Mineral resources or mining activities

Existing water rights

State water plan

Wilderness, roadless, or other special use designation

Fish and game management plans

County or municipal zoning

Columbia River Basin Fish and Wildlife Program

Tribal fishing rights

Impacts on recreational use

Boating safety or conditions

Access opportunities or restrictions

Existing recreational facilities

Loss or diminishment of hunting, fishing, or other recreational use

Visual or aesthetic values

Dewatering as a recreational impact

Local/regional recreation needs

Impacts on water quality

Nutrients

Coliform bacteria

Chemical composition

Dissolved oxygen

Gas supersaturation

Temperature

Suspended solids

Impacts on air quality

Impacts to wildlife habitat

Riparian vegetation

Wetland habitat

Upland vegetation 
Table 1 continued

Impacts to aquatic and riparian habitat

Dewatering

Flow or water stage fluctuations

Stream hydraulics, fish habitat/discharge relationships

Loss of cover

Change in substrate composition from sedimentation, scouring, or loss of gravel recruiunent

Loss of riparian habitat

Loss of benthic (fish food) productivity

Impacts to big game, small game, furhearers, and nongame wildlife species

Loss or alteration of supporting habitat

Disturbance due to project-relared activities, particularly calving and wintering areas

Disruption of wildlife movements

Electrocution of raptors

Increased human access/disturbance

Impacts to anadromous and resident fish species

Loss or alteration of supporting spawning, incubation, fry, juvenile or adult habitat

Blockage of up and/or downstream movements

Direct mortality due to entrapment, impingement, or injury

Direct mortality to eggs or fish due to dewatering or straining

Increased winter mortality

Reduced aquatic invertebrate production and drift

Reduced food input

Gas bubble disease

Quality of fish habitat

Impacts on stream hydrology

Stream channel alteration

Stream channel maintenance and stability

Instream sediment production, storage, and transport

Total sediment load (suspended and bedload)

Flood plain alterations

Impacts on federal threatened, endangered, candidate, or sensitive plant or animal species

Local and off-site impacts of project siting, design, construction, or operational procedures

Sediment production

Mass slumping

Structural failure

Noncompliance with terms and conditions or license articles

Adequate monitoring of project impacts

Capability of project to handle peak (and flood) flows and sediment

(suspended and bedload) loads

Method of handling trapped sediments

Possible cumulative impacts from multiple hydro project development or from hydroelectric development and other non-hydropower activities 


\section{Table 2}

\section{Studies or Actions That May be Required to Assess Impacts and Concerns Associated with Small Hydropower Project Development}

\section{Conflicts with public interest}

Apply for special use permit or right-of-way easement from land management agency

Relate energy production to available supply and demand and identify marketing arrangement

Provide estimates of associated temporary and permanent employment Submit dam safety application

Provide adequate design description, estimated project cost, and estimated power production Cultural resource survey

Statement of financial ability

Project interaction/compatibility with other activities Identify timber production plans Identify grazing rights and range management plan Identify existing mineral claims...cionduct field check for mineral resources Apply for water rights Determine land use designation Idrntify stated management goals Check with appropriate county or municipal zoning commission Assess impacts on fish and wildlife resources. Ensure consistency with the Columbia Basin Fish and Wildlife Program and the Northwest Pop'er Plan Identify tribal concerns

\section{Impacts on recreational use}

identify timing and extent of currejat boating use. Stream flow studies may be required. Identify impacts to safety and passage

Identify current access and describe project impacts

Identify existing recreational facilities and describe impacts

Provide information on current hunting and fishing use and harvest

Evaluate current and potential other recreational uses

Describe existing visual and aesthetic values

Conduct flow study

Describe impact on project on local/regional supply of recreational resources

Proposic recreational development commensurate with the magnitude of the projeci and identified local/regional recreation needs

\section{Impacts on water quality}

Provide description of current watter quality parameters and predict project and construction-related impacts

Apply for water quality certification

\section{Impacts on air quality}

Prepare dus: control plan 
Table 2 continued

Impacts on wildlife habitat

Prepare riparian vegetative cover map and quantify area to be disturbed

or lost using applied valuation procedures such as the Habitat Evaluation

Procedures or Adamus methods

Inventory and prepare wetland and upland vegetative cover map and quantify

area to be disturbed or lost using approved valuation procedures

Impacts on aquatic and riparian habitat

Provide historic flow data and identify source

Describe proposed mode of operation, ramping rates, and turbine

efficiency curves

Conduct instream flow study

Inventory and map stream cover and identify projected changes

Describe existing substrate composition and identify projected changes

Impacts to wildlife species

Identify seasonal use of project area by furbearers, game, and nongame species

Identify wildlife migration routes

Evaluate alternate methods for transmission lines

Predict effects of alternate access plans

Impacts to anadromous and resident fish species

Conduct instream flow study. Identify fish community present. Conduct

survey of anadromous spawning and rearing use

Identify any existing fish passage barriers. Contact agencies for fish

passage facility requirements and design criteria. Develop design drawings and submit for approval

Contact agencies for fish screening requirements and design criteria. Develop design drawings and submit for approval

See Impacts on aquatic and riparian habitat

Survey and quantify aquatic invertebrate community present and quantify drift

Quantify drift of terrestrial organisms

Identify the potential for fish species that may be absent due to barriers, low population levels, or other reasons

Assess the existing fish habitat quality via sampling to estimate the percentage fines and/or percentage embeddedness

Impacts on stream hydrology

Provide baseline information on stream bed geometry

Identify flushing and channel maintenance flows

Determine current and projected sediment production

Construct bedload rating curve. Quantify increased bedload impacts on

fish babitat

Eváluate flood plain impacts

Impacts on threatened and endangered species

Determine presence of threatened, endangered, candidate, or sensitive species Follow requirements of Endangered Species Act as directed

Obtain information of presence of national species of special emphasis, and species of special concern 
Table 2 continued

Local or off-site impacts of project siting, design, construction, or operation procedures

Conduct soil survey and land type inventory. Identify existing man-caused sediment sources. Estimate existing and projected sediment yield under normal and worst-case conditions. Provide an erosion control plan. Apply for stream alteration and 404 permits for intake and outlet facilities

Conduct a soil stability inventory

Provide detailed structural design of project facilities Install agency-approved equipment to continuously monitor bypass flows, dissolved oxygen, and/or temperature

Develop format for compliance reporting. Develop agency-approved reclamation plan

Provide peak (flood) flow and sediment analysis and how project can handle them

Provide estimate of sediment trapping, and means and location for disposing of trapped sediment. If sediment is to be flushed downstream, describe expected timing and capability of downstream segment to handle the releases and the impacts expected from the releases

\section{Cumulative impacts}

Evaluate and quantify the potential for cumulative impacts within and across projects. Consult on the data acquisition needs for preparation of National Environmental Policy Act document

Most projects will not require all of the studies listed or pose impacts across a broad range of categories. Small projects in particular are likely to require fewer studies and permits. Nevertheless, the time requirement for obtaining all permits and licenses may be a substantial part of the total project duration. Therefore, it is important for the developer to initiate the federal, state, and local permit process in the early stages of the project development.

It is important for a prospective developer to regard these various regulatory requirements not as barriers to be surmounted (or circumvented) with minimum effort, but as useful means to identify potential problems associated with a particular site or project design. Agencies responsible for the permits and licenses should be consulted early in the process so that any appropriate modifications to the project can be made in a timely manner. In this way, last minute misunderstandings and unnecessary delays can be avoided. 


\section{Chapter 1 Federal Permit and Licensing Requirements}

\section{Federal Energy Regulatory Commission}

The highest authority in the development of any hydropower project is the Federal Energy Regulatory Commission (FERC). Even though numerous other federal, state, and local agencies will have some jurisdiction and require permits of their own, FERC approval must be obtained before a project can be developed. Conflicts rarely arise between federal, state, and local requirements. However, if they do, federal authority will usually prevail if negotiation cannot result in agreement.

FERC, whose authority stems from the Federal Water Power Act of 1920 , is the agency charged with issuing preliminary permits, licenses, and exemptions from licensing for the purpose of authorizing construction and operation of non-federal hydropower projects. A project is within the jurisdiction of FERC and therefore must obtain a license (or exemption from licensing) if any of the following apply:

1. The project uses water from a navigable waterway. As used here, navigation generally refers to logging activity. A stream large enough to float a $\log$ is generally considered navigable. In practice, to be considered navigable, the stream must have been used for commercial purposes or could be so used again, with improvements. Tributaries to navigable streams are sometimes also included.

2. The project's output will be fed into an interstate utility grid. Virtually all utilities in the Northwest are of this type so all interconnected projects fall within FERC jurisdiction.

3. The project in whole or in part is located on federal land.

4. The project will use surplus water from a federal dam or impoundment.

There are very few proposed hydropower projects that are beyond FERC's jurisdiction. An example of a nonjurisdictional project would be a small plant that is also located totally on private land, serving only the owner's needs and not affecting a navigable stream. However, even very small plants are usually under FERC jurisdiction unless other factors apply. In fact, there is no minimum capacity below which FERC does not have jurisdiction.

If you are uncertain about whether FERC has jurisdiction, obtain an unofficial opinion from the FERC staff. Sometimes this is sufficient; however, if further questions remain, you can file a Declaration of Intention with FERC. This is a relatively simple procedure requiring that you provide the following project information in writing: 
- Stream location (be specific and include maps)

- Head and flow

- Type of diversion

- Power output

- Land ownership

- Intended use for power

FERC will then review the information and make a formal determination of jurisdiction in $60-90$ days.

For projects within FERC's jurisdiction, there are a variety of applications that can be filed. Figure 8 lists those applications in a flowchart format. The regulations governing applications, preliminary permits, licenses, and exemptions from licensing are contained in the FERC publication Application Procedures for Hydropower Licenses, License Amendments, Exemptions and Preliminary Permits.

\section{National Environmental Policy Act (NEPA)}

Federal agencies making decisions on hydroelectric project licenses are required to comply with the National Environmental Policy Act for minor development projects and for the additions of hydroelectric facilities to existing dams. The developer is initially required only to provide enough environmental information for FERC to make a determination of environmental significance.

If the project is determined to be environmentally significant, a full environmental impact statement (EIS) is required. Major projects usually require a full EIS. When a full NEPA EIS is required, it is written by FERC staff using the information provided in Exhibit $E$ of the license application. When necessary, FERC will require that additional studies and information be provided. FERC regulations relating to NEPA are listed in 18 CFR 2 80-2.82.

\section{Electric Consumers Protection Act}

While the Electric Consumers Protection Act (P.L. 99-495) originated to address hydroelectric project relicensing issues, it also contains several provisions designed to instill a new consciousness within FERC regarding the agency's consideration of the environmental and aesthetic impacts of new hydropower developments. The major provisions of the Act are:

- Public Utilities Regulatory Policies Act (PURPA) Benefits for New Dams and Diversions

Except for facilities located at federally-owned dams, PURPA benefits will only be allowed for projects requiring new dams, enlargement of impoundments, or diversion structures if 1) FERC certifies that the new project will not have substantial adverse effects on the environment, 2) the project is not located on a federal-or state-designated wild and scenic river or 

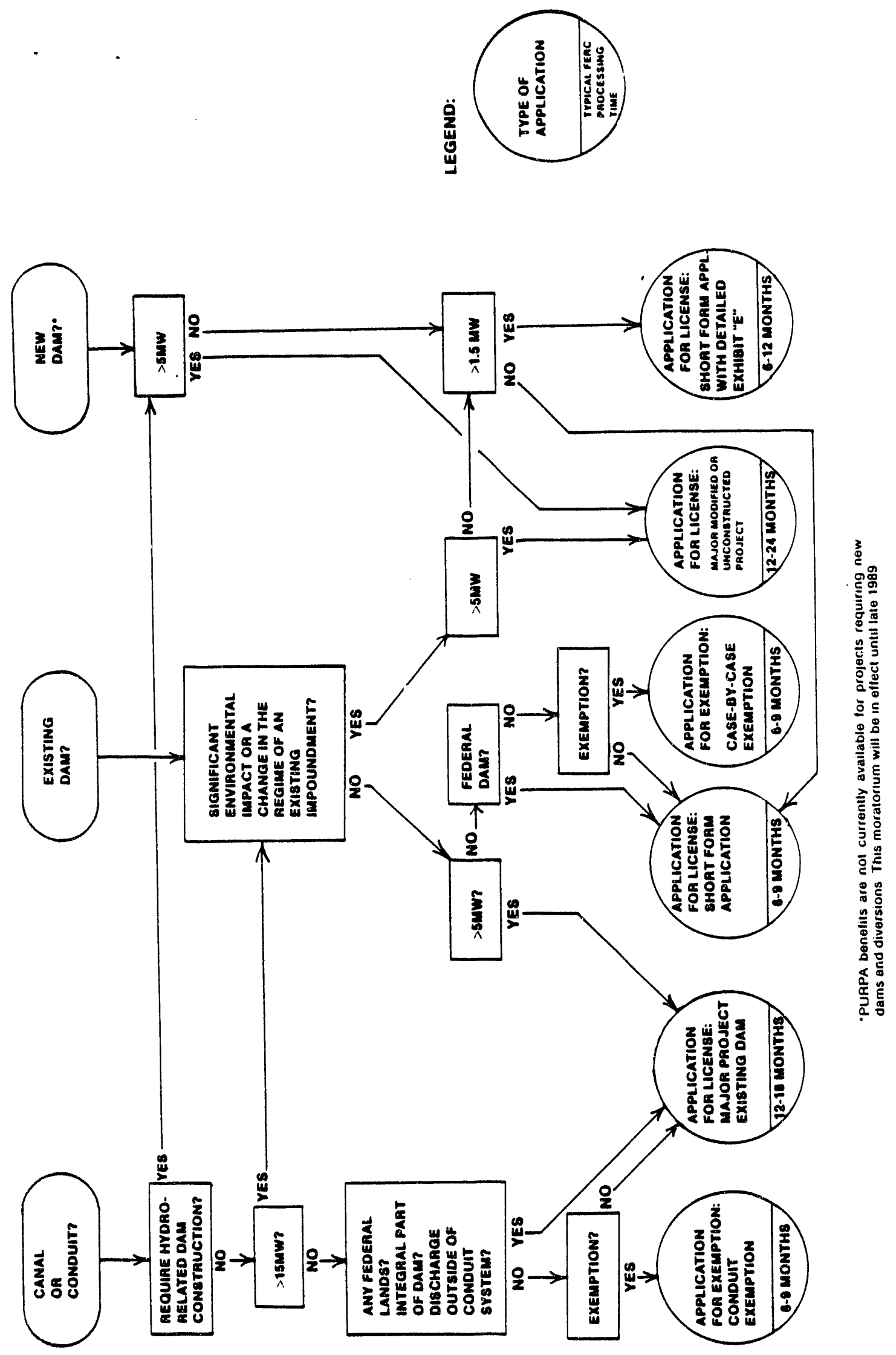

Figure 8: FERC Licensing Requirements 
river that is defined under state law to possess unique natural, recreational, cultural, or scenic attributes that would be adversely affected by hydroelectric development, and 3) the project must meet all terms and conditions imposed by federal or state fish and wildlife agencies.

\section{- Environmental Considerations in Licensing}

In deciding whether to issue a license for power and developmental purposes, FERC is required to give equal consideration to other purposes including fish and wildlife, recreation, irrigation, flood control, water supply, and other beneficial uses. This means that protection, mitigation, and enhancement of fish and wildlife, energy conservation, and the protection of recreational opportunities will be viewed as a standard-one that cannot be met by mere consultation or by deferring consideration of these values until after licensing.

The Act does not give agencies veto power or make their conditions mandatory in licensing cases. However, it does require that FERC accept agencies' recommendations as a basis for imposing lice nse terms and conditions. FERC can only reject the agencies' recommendations if, after consulting with the agencies and attempting to resolve differences, it publishes a finding that the rommendations are inconsistent with the purposes and requirements of the Federal Power Act. FERC's own conditions would then have to give equal consideration to environmental and power development values. In the case of exemptions, state and federal fish and wildlife agencies retain their authority to impose mandatory terms and conditions as under previous law.

- FERC Enforcement Authority

The Electric Consumer's Protection Act (ECPA) provides new authority to FERC to enforce rules and license articles, terms and conditions. FERC is given the power to remedy violations of licenses, permits, exemptions, or commission regulations by revoking licenses or through assessing penalties of up to $\$ 10,000$ per day.

\section{- Comprehensive Planning}

ECPA requires FERC to consider the extent to which a project is consistent with a comprehensive plan (where one exists) for improving, developing, or conserving a waterway affected by the project when the plan is prepared by 1) an agency established by federal law with the authority to prepare such a plan or 2) the state in which the facility will be located.

- Expanded Exemption for State and Local Government Conduit Projects

ECPA expands the eligibility requirement for "conduit exemption" from 15 to $40 \mathrm{MW}$ in the case of projects constructed, operated, and maintained by a state or local government solely for municipal water supply purposes. 
- Fish and Game Fees

In addition to requiring FERC to adopt fish and wildlife conditions imposed by the National Marine Fisheries Service, the Act requires the Commission to establish fees to be paid by a project applicant that are adequate to reimburse the agencies for reasonable costs incurred for studies or mandatory condition compliance reviews.

\section{- Relicensing Preference}

In cases of relicensing of existing facilities, no preference will be given to municipalities. Instead, licenses will be awarded to the applicant whose plans are best adapted to serve the public interest. Where no significant difference exists between applicants, the license will be awarded to the existing license holder.

\section{Preliminary Permits}

FERC's regulations provide a range of altematives for development of a hydropower site. However, the usual first step is to apply for a preliminary permit. The primary reason to obtain a preliminary permit is to preserve priority for later filing for a license or exemption from licensing. These permits allow a specified term, usually from 18 months to a maximum of 3 years, for the prospective developer to perform certain investigations and studies to support a license application. The developer must determine the economic, engineering, and environmental feasibility of developing a hydropower project at a specific site. A prelininary permit does not authorize construction. Construction may not begin until the actual license or exemption is issued and permits have been obtained from appropriate agencies. A preliminary permit is not required and a developer could file for a license or exemption from licensing directly.

An application for a preliminary permit requires details regarding the proposed development "to the extent possible." The extent of information required is commensurate with the scope of the proposed development. An application consists of an initial statement and four exhibits as described below.

- Initial Statement-The initial statement identifies the applicant, gives the name and location of the proposed project, specifies the owner of all lands involved, and states the proposed term of the permit.

- Exhibit 1-This exhibit contains a description of any dams, impoundments, or transmission lines; an estimate of the annual energy production and plant capacity; a statement of the hydraulic head that will be used; and a description of the proposed turbines and generators. In addition, Exhibit 1 contains a legal description of the land within the project boundaries and any other information demonstrating how the project would help develop, conserve, and use the water resources of the region in the public interest.

- Exhibit 2-This exhibit consists of any studies assessing the technical, economic, and financial feasibility of the project, taking into consideration its environmental impacts. Also 
required is a work schedule for the investigations and other studies to be carried out under the permit.

- Exhibit 3-This exhibit is a statement of costs and financing to inform FERC about the applicant's financial ability to carry out the necessary activities under the permit. Any tentative information that is available conceming the ultimate market for the project power should also be included.

- Exhibit 4-This exhibit is a map or maps showing the geographical location of the project, the physical relationship of its principal features, and the proposed project boundary.

\section{Licenses}

A license is basically an approval by FERC to begin construction and subsequently operate a project. However, appropriate approvals and permits that may require payment of annual fees must be obtained from other federal, state, and local agencies before construction can begin. You must have either a license or exemption from licensing, before construction begins or you will be in violation of federal law.

For licensing purposes, projects are designated as "major," meaning that the proposed project would have a total installed generating capacity of more than $1.5 \mathrm{MW}$ or "minor," meaning that the capacity is less than or equal to $1.5 \mathrm{MW}$. Projects are also grouped according to the level of anticipated complexity and potential impact. These guidelines have resulted in the three licensing categories described below.

\section{Major Unconstructed Projects and Major Modified Projects Greater Than 5 Megawatts}

The most complicated license application is for projects with capacities larger than $5 \mathrm{MW}$ that would:

1. Use the water potential of a new dam;

2. Change an existing project and significantly increase the normal area or elevation of the impoundment;

3. Otherwise produce a significant environmental impact.

An application for this license category consists of an initial statement and seven exhibits as described below.

- Exhibit A-This exhibit is a brief description of the project

- Exhibit B-This exhibit is a statement of the project operation and resource utilization

- Exhibit C-This exhibit is a proposed construction schedule for the project

- Exhibit D-This exhibit is a statement of project costs and financing 
- Exhibit E-This exhibit is an environmental report

- Exhibit F-This exhibit consists of general design drawings of the principal project works

- Exhibit G-This exhibit is a map of the project

\section{Major Projects Greater Than 5 Megawatts at Existing Dams}

Preparing an application for a project larger than $5 \mathrm{MW}$ at an existing dam is simpler than for a major unconstructed project. A project qualifies for inclusion in this category if generating equipment is being installed at or added to an existing dam without significantly changing the size or level of the reservoir. The required initial statement and exhibits are similar to those for major unconstructed projects, though not as much detail is required.

\section{Minor Projects and Major Projects 5 Megawatts or Less}

Any project with a total installed capacity of $5 \mathrm{MW}$ or less can file a "short form" license application. The application is basically a simplified procedure to reduce the amount of information required. For projects with capacities of 1.5 to $5 \mathrm{MW}$ at unconstructed sites, the environmental report must conform with the specifications for other projects classified as "major." The environmental report for all projects less than $1.5 \mathrm{MW}$ ("minor") is considerably less detailed. The "short form" application requires an initial statement and the exhibits described below.

- Initial Statement-The initial statement contains the same information as for large projects plus a brief project description and a list of federal lands affected

- Exhibit A-This exhibit is a description of the project and the proposed mode of operation

- Exhibit E-This exhibit is an environmental report

- Exhibit F-This exhibit consists of general drawings of the principal project works

- Exhibit G-This exhibit is a map of the project

\section{Exemptions}

An exemption is not, as the name implies, a total exemption from licensing requirements; rather, it relieves the developer from some of the normal licensing requirements. The intent of instituting the exemption process was to make licensing faster and easier for projects deemed to have minimal impacts. The exemption process has been used by many developers since it was instituted by PURPA in 1978 and later modified in 1980 by the Energy Security Act. The reason for its popularity is that exemptions offer several significant advantages over the normal licensing process. However, exemptions offer some serious disadvantages as will be discussed later. Also, in light of court decisions made in 1984, exemptions are no longer available for certain classes of projects.

FERC's regulations provide the following three types of application for exemption from licensing:

- Small conduit

- Categorical

- Case-specific 


\section{Small Conduit Exemptions}

Projects meeting the following qualifications can qualify for small conduit exemptions:

- An installed capacity of $15 \mathrm{MW}$ or less.

- Located on non-federal lands, and used for generation only the hydroelectric potential of a man-made conduit that was constructed primarily for other purposes such as irrigation, domestic water supply, or industrial use. Projects with capacities up to $40 \mathrm{MW}$ can qualify if they are located on a municipal water supply system. The conduits may be canals, pipelines, flumes, or other similar conveyances. The project must not require construction of a dam to provide the head necessary for power generation. The water used must be received from and discharged back into the conveyance system.

You must file an application with FERC in order to obtain an exemption. Applications are reviewed for adequacy and compliance with regulations. A comment period, usually 90 days, is allowed for protests to be received by the Commission. Exemptions are granted either by affirmative action within the 90 days; or, if FERC has not taken action within this time period, exemption of the project is granted automatically. If the exemption is denied, the application, along with additional information, can be used as the basis for a license application.

An application for a small conduit exemption consists of an initial statement and four exhibits as described below.

- Initial Statement-The initial statement includes the location of the facility, names and addresses of the applicant, and a list of the provisions of the Federal Power Act from which the exemption is requested.

- Exhibit A-This exhibit is a description of the small conduit hydroelectric facility and the proposed mode of operation.

- Exhibit B-This exhibit is a general location map.

- Exhibit E-This exhibit is an environmental report.

- Exhibit G-This exhibit consists of a set of drawings showing the structures and equipment of the proposed facility.

\section{Case-Specific Exemptions}

The Energy Security Act of 1980 made exemptions available on a case-specific basis to projects with specific characteristics. These projects have generation capacities of $5 \mathrm{MW}$ or less and use existing dams or certain so-called "natural water features" such as a natural lake, waterfall, or the gradient of a natural stream, without the need for a dam and man-made impoundment. Projects can qualify for natural water feature exemptions by, for example, diverting water to a turbine from the side of a stream, or generally using structures such as catch-basins or perforated pipes. Dams or diversion structures cannot be used if they obstruct the flow or level of water such that they adversely affect the natural water feature. Projects using dams less than 10 feet in height 
and impounding less than 2 acre-feet of water will no longer qualify for this type of exemption as a result of a Ninth Circuit Court of Appeals decision, Tulalip Tribes of Washington, et al., vs. FERC handed down on May 10, 1984.

Application requirements for case-specific exemptions are nearly the same as those for small conduit exemptions with an initial statement and exhibits A, B, E, and $G$ required. Upon submittal to FERC, the applications are reviewed for adequacy and compliance with regulations. A 120-day comment period is allowed for protests to be received. Exemptions are granted by affirmative action within the 120 days; or, if FERC has not taken action within this time period, exemption of the project will be granted automatically.

\section{Categorical Exemptions}

FERC's regulations once provided for exemption from licensing for two categories of small hydroelectric projects using existing dams with total installed generating capacities of: 1) greater than $100 \mathrm{~kW}$ but $5 \mathrm{MW}$ or less and 2) $100 \mathrm{~kW}$ or less. However, applications for these types of exemptions have not been accepted since June 15, 1983, as a result of legal challenges. Due to the very specific requirements for qualification, most potential sites in the Northwest would not be eligible for either type of categorical exemption. Case-specific exemptions are suggested as an alternative.

\section{Requirements Common to All Exemptions}

All exemptions, regardless of type, are subject to some common requirements. The Federal Power Act requires any project that receives an exemption to comply with the terms or conditions that federal and state fish and wildlife agencies determine to be appropriate. Compliance with all conditions imposed by these agencies is mandatory.

Another requirement common to all exemptions is that developers must have a "real property interest" in the land on which the project will be built. This means that the applicant must own, have leased, or hold an option to purchase the site. By contrast, applicants for preliminary permits or licenses do not have to have a property interest at the time of filing. If only federal lands are involved, any person may file a notice of exemption for the project.

\section{Exemption vs. License}

With both exemptions and licenses available as options, careful consideration should be given in deciding which path to take. There are important advantages and disadvantages to each.

In the past, exemptions have been sought for most projects that could qualify. The principal advantage of an exemption is that much less time and information are required for application. This translates into a faster and less expensive route to project construction. The agency consultation period required to allow agencies to comment is only $\mathbf{3 0}$ days for an exemption, whereas it is at least 60 days for a license. Similarly, case-specific exemptions are granted automatically 
120 days after public notice of application assuming FERC does not take action. Categorical exemptions are granted 30 days after the notice is published. However, a license application requires much more time.

Another advantage to exemptions is that projects operating under an exemption are not required to submit the annual reports required for licensed projects. Since exemptions apply to the site and not to the developers, exemption holders are not required to make annual fee payments to FERC, and restructuring of ownership or project financing is freely allowed once the exemption has been issued.

Along with the advantages of exemptions come several serious disadvantages that are often overlooked by developers. One problem with exemptions is that they require the applicant to hold the necessary property rights. If a property rights dispute arises between any parties, not just with competitors, FERC will simply reject the application and make no attempt to determine ownership of property rights.

A second potential problem with exemptions is that an issued exemption could be subject to future takeover by a license application that proposes a superior development. While the possibility is remote, the consequences are severe as no compensation to the exemption holder is required under federal law. State or local laws may offer some compensatory relief, however.

In some situations, additional potential problems should be considered. Unlike licenses, exemptions are not conferred the right of eminent domain. Land that might be necessary for access roads or transmission line right-of-way cannot be condemned. Another point to consider is that the municipal preference provision of the Federal Power Act and the preference accorded to preliminary permit and license applicants do not apply to the exemption process. This is because FERC did not foresee any competition at exemption sites as a result of the property rights requirements.

\section{Licensing Considerations}

\section{Municipal Preference}

FERC is required by the Federal Power Act to give preference to applications by states and municipalities when their applications are in competition with those of private entities. As defined, a municipality can include a city, county, irrigation district, drainage district, or other political subdivision or agency of a state. Preliminary permits or licenses will be granted first to a municipality if the plans of the municipality are as well-adapted as the private competitors. If the municipality's plans are not as well adapted, FERC will inform the municipality of the specific deficiencies and the municipality will be given a reasonable period of time within which to improye its plans. If the municipality submits a proposal equal to its competitor's, it will be favored in preliminary permit and license application proceedings. Municipal preference is not 
awarded for permits competing against exemption applications. In cases of relicensing of existing projects, a license will be issued to the applicant whose plan is best adapted to the public interest. Municipal preference is specifically denied in cases of relicensing.

"Hybrid" applications-those filed jointly by a municipality and a priyate developer-will be accepted by FERC but will not be afforded municipal preference. They will be subject to the same competition faced by applications filed by private developers alone and will be treated the same as any other application. Hidden hybrids-those in which a municipality's participation is used to help a private entity gain an advantage as a result of the municipal preference clause-are strictly prohibited by FERC and subject to severe penalties should such arrangements be discovered. A municipality cannot help a private developer gain any advantage whatsoever under the municipal preference clause.

\section{Competing Application}

In many cases, two or more parties file preliminary permit or license applications for the same site. If one of the applicants is entitled to municipal preference and its plans are at least as well adapted as the plans of the other applicants, it will be favored for a preliminary permit. Where no preliminary permit has been issued, a municipality will be favored for a license (except for relicensing). Where none of the applicants for a preliminary permit has a municipal preference. the permit will be granted to the applicant whose application was first accepted for filing. The same rule applies for licenses, assuming none of the parties hoids a preliminary permit. If, however, one of the parties has preference by virtue of holding a preliminary permit, FERC will favor the permit holder if its plans are at least as well adapted as those of the other applicants. If the permit holder's plans are not as well adapted, they will be informed of the reasons why and allowed a reasonable period of time to improve their plans. If the permit holder can make their plans at least as well adapted as the other's, they will be favored.

\section{Agency Consultations}

Consultation with numerous federal and state agencies is required when filing for licenses and exemptions. The consultations provide a basis for analysis of environmental and natural resource management aspects of a proposed project and identify problems that should be considered in FERC's licensing procedures. Consultation can begin at the preliminary permit stage and is required prior to submittal of a license or exemption application. FERC's requirements concerning agency consultation can be found in the Code of Federal Regulations, 18 CFR 4.38.

The consultation process consists of three stages. During the initial stage, applicants are required to contact all appropriate agencies and provide each with specific, detailed information, to the extent available, conceming the project including maps, engineering design, operational mode, streamflow data, affected environment, and proposed mitigation and enhancement plans. The information provided should convey a precise description of the project so that the agencies and members of the public may fully understand the proposed project. Applicants should seek the 
agencies' advice as to potential impacts and what studies may be necessary to assess the effects of the project on the area's natural and socioeconomic resources. Initial consultation is useful to an applivant in budgeting study expenditures. For example, an applicant might find, after discussions with appropriate agencies, that the project is wholly or partly unfeasible, or otherwise poses unforeseen environmental problems. Consultation helps to ensure the preparation of acceptable applications and expedites further interagency consultation.

During the initial consultation phase, applicants should not restrict themselves to merely providing information to the agencies. An effort should be made to determine the types of studies agencies consider necessary, the information they have in hand, their concerns about the environmental consequences of the proposed project, and their ideas about mitigation of adverse impacts or en rancement of resources.

Areas of disagreement between applicants and agencies should be isolated and an attempt made to resolve conflicts. Applicants should be aware that if they and the agencies cannot resolve their conflicts, FERC will give weight to the agencies' expertise in deciding whether the applicants performed adequate studies. Therefore, consultation does not consist merely of a transfer of information; ideally, it is a period of extensive communications in which agencies and applicants are fully acquainted with one another's assessment and priorities regarding the environmental dimensions of the project.

During the second stage of consultation, applicants must perform any reasonable studies that are necessary for FERC to make an informed decision regarding the merits of the application. Studies must be conducted prior to filing an application if the results: 1) would influence the economic or technical feasibility of the project; 2 ) are needed to determine the design or location of project feasibility; 3) are needed to determine the impacts of the project on important natural or cultural resources; 4) are necessary to determine suitable mitigation; and 5) are necessary to minimize impacts to a significant resource. 'The results of any necessary studies must be provided to each agency along with a draft application. Applicants must respond in the draft application to any comments and recommendations made by agencies during the initial stage.

Applicants are required to provide consulted. agencies either 30 or 60 days, depending on the type of application, in which to analyze and respond to the applicant's development plans. These time periods begin only after the applicant has informed the agencies of its general plans and submitted all studies required by the agencies. If an applicant strongly believes that particular studies are unnecessary, the applicant can refuse to perform those studies and file its application with an explanation of why these studies were not conducted. The applicant bears the burden of proving to the Commission that the omitted studies were unnecessary.

In addition to studies that the applicant may carry out, fish and wildlife agencies themselves may conduct any studies necessary to set appropriate terms and conditions for licensing. Fees for performing these studies will be assessed and collected by FERC for reimbursement to the agencies. 
The third stage of consultation consists of the application being filed with the Commission and served on each of the agencies consulted. Any subsequent revision, amendment, or supplement of an application also must be provided to each consulted agency. Documentation that the requirements of all three stages of the consultation process have been satisfied must be included in the application, as well as any agency letters containing comments, recommendations, or terms and conditions.

If the appropriate agencies waive compliance with any requirement, the applicant can omit compliance with that requirement provided that the application includes an explanation of the circumstances of the waiver.

Projects for which exemptions are issued are subject to any terms and conditions that are submitted by relevant federal and state agencies to protect or enhance fisheries resources. Exemptable projects must either have certification from the fish and wildlife agencies that there is not a significant population of migratory fish at any proposed dam, or if there is, that the project does not obstruct the passage of migratory fish. Applicants must also certify that they will comply with any future restoration program affecting the exempted project.

One final point should be made conceming consultation with fish and wildlife agencies. Some agencies do not attempt to intervene into the licensing process or impose conditions on exemptions until a developer has reached the actual licensing or exemption stage. Simply because an agency does not voice any opposition to a proposed project during the preliminary permit stage does not mean that it will not voice opposition later. The agencies realize that approximately one-fourth of all projects granted preliminary permits go on to the licensing or exemption stage, and protesting all preliminary permits would be in vain. Therefore, it is strongly advised that developers contact agencies early to avoid costly mistakes, in terms of both time and money, of obtaining a preliminary permit and subsequently being faced with insurmountable environmental opposition when applying for a license or exemption.

\section{Federal Regulatory Acts Affecting Hydro Development}

$\begin{array}{ll}\text { Federal Power Act } & 16 \text { USC 791a } \\ \text { Electric Consumers Protection Act } & \text { P.L. 99-495 } \\ \text { National Environmental Policy Act } & 42 \text { USC 4321 } \\ \text { Fish and Wildlife Coordination Act } & 16 \text { USC 661 } \\ \text { Historic Preservation Act } & 16 \text { USC 470A } \\ \text { Wilderness Act } & 16 \text { USC 1131 } \\ \text { Clean Water Act } & 33 \text { USC } 1251 \\ \text { Wild and Scenic Rivers Act } & 16 \text { USC } 1271 \\ \text { Endangered Species Act } & 16 \text { USC } 1531 \\ \text { Coastal Zone Management Act } & 16 \text { USC } 1451 \\ \text { Federal Land Policy \& Management Act } & 43 \text { USC } 1701 \\ \text { Public Utilities Fegulatory Policies Act } & \text { P.L. 95-619 } \\ \text { Pacific NW Electric Power Planning \& Conservation Act } & \text { P.L. 96-501 }\end{array}$




\section{Federal Agencies}

The concems, policies on intervention, and possible mitigative measures that may be required for projects are described below for the various federal agencies.

\section{Fish and Wildlife Service}

The U.S. Fish and Wildlife Service must be consulted whenever the water of any stream or other body of water are proposed or authorized to be impounded, diverted, the channel deepened, or the stream or other body of water, including wetlands, otherwise controlled or modified for any purpose.

\section{National Marine Fisheries Service}

If a proposed project may affect anadromous, estuarine, or marine fish resources, or their present or potential future habitats once restoration goals are met, the National Marine Fisheries Service (NMFS) must be consulted. A copy of NMFS' regional policy on small hydropower is available upon request from the agency.

\section{Corps of Engineers}

If the project includes the placement of material into waters of the United States, including wetlands, authorization is required for such placement from the Corps of Engineers under Section 404 of the Clean Water Act. Authorization under Section 404 may be by individual permits or general permits on a regional or nationwide basis.

\section{Forest Service}

If any part of a project is on National Forest System lands, a Memorandum of Agreement or Special Use Permit is required prior to the issuance of a preliminary permit or license. The approval should take a minimum of three months and may require some fees. Contact should be made with the local U.S. Forest Service Ranger during the design phase of the project to gain an understanding of information and data required before the Forest Service can determine if the proposed use will be authorized.

When issuing a special use permit, the Forest Service imposes conditions that affect the amount of water available for the proposed project. Persons applying for water rights from the state should be urged to contact the Forest Service as early in the process as possible to find out what Forest Service water rights are, especially for instream flows. 


\section{Bureau of Land Management}

All project features on public lands will require land use authorizations prior to any ground-disturbing activities. A cultural resource inventory will be required. This inventory must be conducted by a qualified archaeologist with a current Bureau of Land Management Cultural Resource Use Permit.

\section{Bureau of Indian Affairs and Local Indian Tribes}

If any part of a project is on an Indian reservation, on land bordering a reservation, involves a stream that impacts a reservation, or affects Indian fishing rights, the developer should consult with the nearest Bureau of Indian Affairs office, the local tribal headquarters, and in the Columbia River Basin, the Columbia River Intertribal Fishery Commission.

\section{Federal Aviation Administration}

A permit from the Federal Aviation Administration (FAA) is required to ensure that none of the project features represent a hazard to aviation (e.g., transmission towers). The FAA application forms, along with a project map showing elevation contours, microwave towers, and existing airports, may be required. Approval of this permit requires approximately 2 months.

\section{Federal Communication Commission}

Hydroelectric projects using remote radio operation generally will require a permit from the Federal Communication Commission (FCC). The developer should contact the FCC to determine which radio frequencies are available and to obtain the necessary application forms. The specific permit requirements depend upon the strength of the signal and the amount of time the transmitter is to be used.

\section{Environmental Protection Agency (EPA)}

For most small hydropower projects, EPA is responsible for reviewing and approving of any Corps of Engineers' dredge and fill (404) permits. EPA's primary concern will be that adequate consideration be given to dredge and fill altematives (i.e., whether a less environmentally damaging practicable altemative may exist) and that full mitigation for unavoidable impacts occurs consistent with EPA's 404 Mitigation Policy. Copies of the policy are available from the EPA. The policy basically requires that diverse impacts be avoided entirely when possible, reduced or minimized when practical, or compensated for by replacing or providing substitute resources or environments of equal or greater value, which may be more than simply acre-for-acre mitigation. Because of the emphasis on evaluation of alternatives, it is strongly suggested that applicants initiate coordination with both the EPA and Corps of Engineers as early as possible in their planning. 


\section{National Park Service}

If any part of a hydropower project is located in or near a unit of the National Park System, a "designated" or "study" river in the National Wild and Scenic Rivers System, a river listed on the Nationwide Rivers inventory, or a river listed in the 5(a) Rivers Inventory, contact must be made with the National Park Service. Each of the above categories has differing requirements regarding the location of hydro projects within their boundaries. If it is unclear whether any of these designated areas are affected by a particular hydro site, a list may be obtained from the National Park Service. Reports on historic and archaeological resources and on recreational resources as required by Exhibit $E$ of the license application should be prepared in consultation with the National Park Service for all projects.

\section{Bureau of Reclamation}

Applicants for preliminary permit or license should consult with the regional office of the Bureau of Reclamation during preparation of an application. If the project would affect or utilize a Bureau dam or irrigation facility, the regional office would comment on the application and recommend any specific conditions to be included in any permit or license. The regional office would also comment as to the status of whether a Bureau dam or irrigation facility is authorized for federal power development and comment on the status of any water rights that may be affected by a proposed project.

\section{Permit or Regulation: National Pollutant Discharge Elimination System (NPDES) or 402 Permit}

Agency: Environmental Protection Agency (EPA)

A NPDES permit is required where a waste water source is discharged to "waters of the United States." For more information, contact the EPA office listed in Appendix 1A.

If a hydropower project affects the quality of water in any way by adding sediments, decreasing oxygen content, or increasing temperature, this may be construed as discharging a pollutant and requires a NPDES or 402 permit. Typically, NPDES permits are not required for small-scale hydropower projects.

The application requires information on waste source flow and expected characteristics, disposal method, water supply, waste water disposal, water supply volumes, water utilization, planned improvements, storm water treatment, plant operation, materials and chemicals used, and production. Prior State Environmental Policy Act (SEPA) compliance is required. 


\section{Permit or Regulation: Federal Water Pollution Control Act}

\section{Agency: Environmental Protection Agency (EPA)}

Section 301 A "point source" of pollutants cannot discharge into navigable water without a NPDES permit. A "point source" is a discemible, confined, discrete source. An industry or sewer outfall is a point source. An eroding hillside generally is not a point source. Discharges from normal farming, silvaculture, and aquaculture practices do not need permits.

Section 303 This section authorizes states to adopt water quality standards. State standards are to consider the value of water for public drinking supplies, propagation of fish and wildlife, and recreation, among other uses. Each standard considers the respective uses and value of the water and includes criteria based on those uses.

Section 401 An applicant for a federal license or permit for an action that "may result in any discharge" into navigable waters must comply with federal and state water quality standards. Applicants must obtain a certificate that all discharges will comply with the standards.

Section 401 requires a certificate for any discharge. It applies even when a water user does not add anything to discharged water. For instance, a dam or diversion adds nothing to the water. But, it may diminish flow needed to dilute downstream wastes. It may also change naturallyoccurring temperatures and dissolved oxygen level. If a state rule on one of these water quality parameters is violated, a certificate of compliance will be denied.

Section 401(b) also requires that discharges comply "with any other appropriate requirement of state law." Section 401(d) has been construed to require federal permits and licenses be granted subject to any appropriate requirement of state law.

\section{Permit or Regulation: Noise Control Act and Executive Order 12088} Agency: Environmental Protection Agency (EPA)

This Act contains standards with which federal actions are encouraged to comply. It does not require approval of a noise permit. The Executive Order required federal actions to comply with state and local noise regulations where they exist.

\section{Permit or Regulation: Federal Procedures for the Protection of Prehistoric and Historic and Cultural Properties \\ Statutory Authority: Section 106, National Historic Preservation Act 1966; National Environmental Protection Act of 1969; 36 CFR 800 Agency: Office of Archaeology and Historic Preservation}

All federal agencies are required by law to take into account the effect of their activities or archaeological and historic properties. Federal agencies have developed different procedures for 
evaluating the effects of their projects. Federal agencies are required to contact the state Historic Preservation Office to obtain the state's comments on the significance of a historic property and on the effect of a project on the property.

Step 1: Identify and evaluate historic properties. First, the federal agency reviews all of the available information that could help in determining whether there may be historic properties in the area of the proposed activity. Based on this review, the agency decides whether any additional survey work is needed to locate possible historic properties.

Next, the agency identifies all National Register properties that might be affected by the proposed activity. The agency also identifies properties not actually listed in the Register, but which appear to meet eligibility criteria. Then the agency and the State Historic Preservation Office (SHPO) together apply the National Register criteria to decide whether the properties are eligible for listing, and thus subject to the Section 106 process.

Step_2: Assess effects. Once historic properties have been identified and found to meet National Register criteria, the federal agency determines whether its proposed activity will affect them in any way. Again, the agency works with the SHPO, making judgments based on criteria found in the Advisory Council's regulations. There are three possible findings:

No effect: If there will be no effect of any kind on the historic properties, the agency notifies the SHPO and interested parties of its determination of no effect. If the SHPO does not object, the agency proceeds with the project.

No adverse effect: If there could be an effect, but the effect would not be harmful to the historic properties, the agency obtains SHPO concurrence and submits to the Council a determination of no adverse effect. Or, the agency can submit its determination of no adverse effect directly to the Council for review and notify the SHPO of its determination. Unless the Council objects, the agency proceeds with its project or activity.

Adverse effect: If there could be a harmful effect to a historic property, the agency begins the consultation process.

Step 3: Consultation. During this step, an effort is made to find acceptable ways to reduce the harm ("avoid or mitigate the adverse effect") to the historic properties. The consulting parties are the agency and the SHPO; Council involvement in consultation is optional. Other interested parties (such as a local government, Indian tribe, or federal applicant for a grant, license, or permit) may also be invited to join the consultation, and must be invited under certain circumstances.

The agency gathers the necessary documentation, informs the public that consultation is underway, and works with the consulting parties to find a solution. When the consulting parties have agreed on steps to avoid or reduce harm to historic properties, they sign a Memorandum of Agreement (MOA). 
In a very few cases, the consulting parties cannot agree on a solution, in which case the consultation is terminated. The agency may then submit documentation to the Council and request the issuance of written Council comments.

Step 4: Council Comment. Unless the Council has already signed the MOA (by virtue of being a consulting party), the agency submits the signed MOA to the Council for review. The Council can accept the MOA, request changes to it, or opt to issue written comments on the proposed activity.

If the consulting parties have terminated consultation, the Council issues written comments about the proposed agency action directly to the head of that agency.

Step 5: Proceed. If the Section 106 review process has resulted in a Council-accepted Memorandum of Agreement, the agency proceeds with its proposed activity according to the terms of that MOA. Without an MOA the agency must take into account the Council's written comments, after which the agency makes the final decision about how (or whether) to proceed with its proposed activity. The agency notifies the Council of its decision.

Either outcome concludes the Section 106 review process and satisfies the agency's statutory responsibilities under Section 106 of the National Historic Preservation Act of 1966.

\section{Annual Charges for Use of Government Dams and Other Structures}

An annual charge is levied against licensees who use government dams for hydroelectric projects. To determine this charge, FERC's final rule, Order No. 379, establishes a graduated flat rate based on the amount of energy produced. As it now stands, the annual charges are determined as follows: 1 mill per kilowatt-hour ( $\mathrm{kWh}$ ) for the first 40 gigawatt-hours (GWh) of energy a project produces, $11 / 2$ mills per $\mathrm{kWh}$ for amounts greater than $40 \mathrm{GWh}$ up to and including $80 \mathrm{GWh}$, and 2 mills per $\mathrm{kWh}$ for any energy the project produces over $80 \mathrm{GWh}$.

\section{Indian Treaty Rights}

\section{Underlying Rights and Principles}

In the 1850 s a series of treaties were negotiated between the United States and a number of the Indian tribes in the Washington Territory. The chief negotiator for the United States was Isaac Stevens. The United States Congress gave Stevens a mandate to sign treaties with the Indians in order to extinguish their aboriginal title to the land so as to open it to settlement.

In the Puget Sound and coastal regions of the state, the Indian peoples primarily relied on anadromous fisheries. In the Columbia River Basin salmon and steelhead were important, but hunt- 
ing for game was also significant. In exchange for giving the United States title to most of their land, the Indians retained reservations for homelands as well as a right to continue hunting and fishing at their usual and accustomed places, both on and off reservation.

The right to take fish and wildlife under treaty is a property right. Each tribe that signed a treaty has a property right to the use of the resources in question. As a property right retained from prestatehood, treaty rights are in the nature of easements on other real property interests and when necessary, protect the right to take fish and wildlife.

Many treaties were negotiated, executed, and ratified by Congress well before statehond. In the ensuing decades, the treaties were interpreted by the federal courts. The court rulings followed earlier Supreme Court rules concerning Indian treaties and established several basic principals. Most fundamentally, the rights retained by the tribes are reserved rights, that is they are rights retained by them at the time of treaty-making and not given to them by the United States.

Treaty rights have also been found by the federal courts to include an environmental right. The courts have held that the resource must be protected in order to effectuate the right to take fish and wildlife. For example, court decisions have forbidden actions that would inundate usual and accustomed fishing sites, dewater fish habitat, or degrade water quality to the detriment of the fishery.

Finally, and perhaps most significantly, the tribes as govermmental entities have a right to mana ze the resource. This means that the tribes set their own seasons and undertake all other activities necessary to adequately manage the resource, including protecting the environment necesary to sustain the resource. The tribes work cooperatively with the state and federal management agencies, and are viewed as co-managers of the resource.

\section{The Effect of Treaty Rights on Hydroelectric Development}

The Federal Energy Regulatory Commission has recognized the tribes' management interests in the fish and wildlife resources of the Northwest. The most obvious example of this recognition is the standard inclusion in preliminary permits of a requirement that the permittee consult with Indian tribes having treaty rights to resuurces potentially affected by the proposed project. Even if such a condition is not included in a preliminary permit, you are well advised to determine and seek out tribes with treaty rights in the area.

Under section 4(e) of the Federal Power Act, the Secretary of the Interior has an obligation to submit license conditions to FERC that are necessary to protect the treaty reserved right to fish and wildlife. These conditions must be included in the license by FERC. Tribal input in the 4(e) process occurs through the Fish and Wildlife Service and the Bureau of Indian Affairs.

A similar process occurs regarding terms and conditions in license exemptions. The tribal management and environmental biologists submit the terms and conditions necessary to protect the resource through the Fish and Wildlife Service. FERC imposes these terms and conditions on 
the developer. It is in the developers' best interests to consult with tribal as well as state and federal fisheries management agencies as early as possible in the exemption process to ensure that he or she can cope with the eventual terms and conditions.

In general, the anadromous fisheries and wildlife considerations of the tribal management and environmental staffs are similar to those of the state and federal fish and wildlife management agencies. In fact, the state, tribal, and federal fisheries management agencies cooperate with each other in their mutual efforts to protect and enhance the resource. Nevertheless, as independent governmental entities with potentially different goals in the management of the resources, tribes should be independently approached for consultations regarding what is necessary to protect tribal interests.

\section{Indian Cultural and Archaeological Concerns}

Indian groups and individuals have an interest in archaeological resources that may be adversely affected by hydroelectric development. Indians have lived in the Northwest for thousands of years. Evidence of their occupancy is found in such places as a shelter on the Hoko River and petroglphys at Vantage, Washington, and numerous village sites. It is believed that many archaeological resources have not yet been discovered, or have not been adequately researched by trained professionals. The tribes are becoming increasingly active in protection and interpretation of archaeological resources.

A number of laws are designed to protect archaeological resources. The National Historic Preservation Act requires consultations with the State Historical Preservation. The Archaeological Resources Protection Act protects sites on federal and Indian lands. State laws govern nonfederal sites and removal of human remains.

These laws require that the developer determine what, if any, resources are present in the project area. FERC routinely includes in its permit and licensing orders a requirement that the developer consult with the State Historic Preservation Officer to determine what resources are present. In most cases, the SHPO requires the developer to conduct surveys to accomplish this objective.

In recent years, as tribes have become better organized to protect their interests, FERC has also required that developers consult with the tribes. If SHPO determine that there is a probability of resources being present, it would certainly be in the developer's best interest to seek out the local Indian tribes to determine their interests.

\section{Federal and State Regulatory Acts Protecting Indian Cultural and Archaeological Sites}

National Historic Preservation Act, 16 U.S.C., Section 470.

Archaeological Resources Protection Act, 16 U.S.C., Section 470.

American Indian Religious Freedoms Act, 42 U.S.C., 1996.

State Archaeological Sites and Resources Act (Washington), RCW 27.53.

Indian Graves Law (Washington), RCW 27.44. 


\section{Power Sales}

The culmination of any successful resource development project is the sale of electrical output. A number of federal and regional agencies have played an important role in the establishment of the framework within which power sales are negotiated and entered into, including price structure and utility interconnection. Much of the legal framework was established in 1979 with the passage of the Public Utilities Regulatory Policies Act (PURPA) (P.L. 95-617), which provided developers of renewable energy projects with an opportunity to market electricity directly to utilities without fear of public utility regulation.

At the federal level the Federal Energy Regulatory Commission (FERC) plays the dominant role while regionally the Northwest Power Planning Council (NPPC) and the Bonneville Power Administration (BPA) are the principal players. Each of the states has also enacted legislation or administratively addressed the needs of non-utility developers of generation projects.

FERC is the most important federal agency relating to Qualifying Facilities (QFs) and PURPA. Because in most states the electric grid and gas pipelines extend over state lines, the FERC has primary jurisdiction over a state's utilities. Nonregulated utilities, i.e., those not state-regulated. and federal power marketing agencies are regulated by FERC. Also, FERC regulates all wholesale transactions between utilities, federal power marketers and QFs. Transactions between direct service industries and federal power marketers are FERC-regulated. In the case of PURPA, the states are required to implement the FERC rules for state-regulated utilities.

Aside from issuing PURPA rules, FERC has a major role in several areas that affect QFs. Of primary importance to developers is the QF certification process. Although FERC has rules for QF self-certification, many QFs seek FERC certification. Persons financing QFs often want to remove any uncertainty about qualifying status. However, seeking FERC certification opens a public comment period during which project opponents have standing to submit objections. FERC certification also is expensive. Recently, the certification process has been used by some developers to get qualifying status for their facility including miles of dedicated transmission lines. Such lines can extend the rights and obligations granted QFs by PURPA into other utilities' service territories. FERC is also playing a major role in expanding the market place for non-utility wholesale generation and addressing problems associated with transmission access and wheeling.

\section{Public Utilities Regulatory Policies Act (PURPA) Overview}

Congress enacted the Public Utilities Regulatory Policies Act (PURPA), P.L. 95-617, on November 9, 1978, as one of five component bills to the National Energy Act of 1978. PURPA was designed to lessen the country's dependence on foreign oil by requiring state utility commissions to consider rate structures that conserve energy and by encouraging the develop-ment of energy efficiency, cogeneration, biomass-fired power plants, and renewable generating resources. Renewable resources include solar, wind, hydropower, and geothermal generating facilities. 
PURPA amended the Federal Power Act to reduce or eliminate obstacles to the development of cogeneration and small power projects. In effect, PURPA requires utilities to interconnect with qualifying cogenerators and small power producers (QFs) located in their service territories, to purchase power at a price based on the utility's full avoided cost for energy and capacity, and to provide non-discriminatory rates for back-up services. PURPA also exempts small power producers from portions of the Federal Power Act, 16 USC 791a-828c (1981), the Public Utility Holding Company Act of 1935, 15 USC 79b(a)(3), and certain state utility regulations. PURPA does not, however, require a utility to interconnect with and purchase power from independent producers located outside of its service territory.

Of particular importance to independent power producers are the provisions of PURPA dealing with small power production. Specifically, under Title II Sections 201 and 210, the Federal Energy Regulatory Commission (FERC) amended its regulations to deal with such critical issues as size, ownership, and efficiency criteria for qualifying small power production and cogeneration facilities; electric utility obligations; rates for purchase and sales; interconnection cost reimbursements; and state implementation requirements regarding PURPA. (These changes are located in Title 18 of the Code of Federal Regulations, Chapter I, Part 292.)

\section{Qualifying for PURPA Benefits}

Two basic types of QFs exist: small power producers and cogenerators. Small power producers generate electricity from fuels other than oil and natural gas, i.e., geothermal, biomass, hydro. A small power producer (SPP) is automatically a QF under PURPA if it meets specified size, fuel use, and ownership criteria. Oil or gas-fired cogeneration projects must meet additional operating and efficiency standards to be considered QFs.

General QF criteria require that the total power production capacity of a SPP (together with the capacity of other facilities owned by the same person, using the same energy resource, and located at the same site) cannot exceed $80 \mathrm{MW}$. The $80 \mathrm{MW}$ limitation on geothermal power production was eliminated in 1990 under provision of P.L. 101-575. Cogenerating QFs have no size limitation. In addition, no more than 50 percent of the equity interest in the facility can be held by an electric utility or utilities, an electric utility holding company, or combination thereof. For multi-fuel fired facilities, at least 75 percent of the total energy input must be from biomass, wastes, renewable resources, including geothermal resources, or any combination thereof. Conversely, during any calendar year, supplemental oil, natural gas, or coal use cannot exceed 25 percent of the total facility energy input.

\section{Regulatory Exemptions}

One of the three objectives of PURPA is to exempt QFs from regulation as electric utilities. FERC regulations do so by providing certain exemptions from the Federal Power Act (FPA), the Public Utility Holding Company Act of 1935, and state laws and regulations (see 18 CFR 
292.601 and .602). These exemptions apply only to financial, organizational and rate issues. They do not affect environmental, zoning, planuing, construction, licensing, or any other laws or regulations related to generating plants.

QFs are exempt from the FPA as follows:

- In general, small power producers (SPPs) are QFs if they have a design capacity of up to $80 \mathrm{MW}$. This restriction was removed from geothermal power production under provision of P.L. 101-575. However, only SPPs of $30 \mathrm{MW}$ or less are exempt from any part of the FPA. All qualifying cogeneration facilities are exempt.

- SPPs of under $30 \mathrm{MW}$ are exempt from the traditional rate regulation and the regulation of securities of public utilities (sections 119, 120, 203, 204, 205, 206, 208, 301, 302, and 304 of the FPA).

QFs are not exempt from certain FPA provisions. Thus QFs:

- are not exempt from most of Part I, which deals with license and permit requirements

- $\quad$ are not exempt from Section 202(c) under which QFs may have to provide energy if the Economic Regulatory Administration determines there is an emergency

- are not exempt from sections 210,211 and 212, which provide for interconnection orders by FERC and allow a utility, federal power marketing agency or geothermal $Q F$ to seek a wheeling order against a utility in a formal FERC proceeding

- are not exempt from Section 305(c), which imposes reporting requirements on interlocking directorates

- are not exempt from Part III, which has enforcement provisions, when the enforcement provisions apply to those sections from which the QFs are not exempt (listed above).

Certain QFs are exempt from all provisions of the Public Utility Holding Company Act of 1935 (PUHCA). These QFs include all geothermal, biomass and cogeneration (CG) facilities (up to $80 \mathrm{MW}$ ). However, other SPPs are exempt only if their design capacity is $30 \mathrm{MW}$ or less.

Such review and enforcement is not confined to whether or not the state commission or non-regulated utility properly put into effect regulations implementing PURPA 210. It also can include the case-by-case application of regulations.

The QFs described immediately above also are exempt from state laws and regulations regarding electric utility rates, finances, and organization. However, they are not exempt from the state laws and regulations intended to implement subpart C of PURPA 210, which governs sales and purchases between QFs and utilities. State commissions and nonregulated utilities may apply to the FERC for a waiver from this broad exemption. 


\section{Summary of Exemptions \\ from Regulations}

Law

Federal Power

Act (FPA)

Who is

Exempt

SPPs $30 \mathrm{MW}$ or less; all $\mathrm{CGs}$

SPPs $30 \mathrm{MW}$ or less, except biomass up to $80 \mathrm{MW}$; all CGs

Holding Company

Act (PUHCA)

State rules

and regulations
Same as PUHCA
From Which

Section

$119,120,203,204,205$, $206,208,301,302,304$ (regarding rate regulation and regulation of securities of public utilities)

All

All governing finance. organization, and rate issues, except those implementing subpart C of the PURPA 210 rules.

\section{Enforcement Procedures Summary}

Orcier of

Redress

First

Second

Third
For Actions

by Regulated

Utilities

State commission

State court or FERC

Federal Court
For Actions

by Nonregulated

Utilities

FERC

Federal Court

\section{PURPA Enforcement}

The FERC regulations implementing PURPA set certain procedures for enforcement and redress of grievances. Persons may go to state court or, under certain circumstances, to the FERC to require a state commission or nonregulated utility to implernent the PURPA regulations, or to require enforcement of the implementation by the commission or nonregulated utility. Persons seeking review of any determination made by a federal power marketing agency may go to the appropriate federal court.

A state commission or nonregulated utility may require utility cost data that is different from what the PURPA regulations require. If a QF cannot derive the utility's avoided cost from this alternative data, the QF may go to court. 
Small utilities need only provide system cost data on request of a $Q F$. If such a utility fails to provide this information, the QF may apply to the state commission (if the utility is regulated) or to FERC (for any kind of utility) for an order that it be supplied. However, the commission or FERC should take into account the burden imposed on small utilities.

If a larger atility (greater than 500 million $\mathrm{kWh}$. year in sales) does not provide the required avoided cost data, the FERC may prescribe the penalties in PURPA Section 133.

The FERC may revoke the qualifying status of a QF if appropriate. It may do so on its own initiative or if requested by some other party. It: must first provide an opportunity for hearing.

\section{Federal Agency Contracts And PURPA}

Section 210(i) of PURPA relates to the effects of contracts between federal agencies and electric utilities on PURPA Section 210 implementation. Clauses in post-1978 contracts for the wholesale sale of electricity to a utility are voided to the extent they interfere with the utility's implementation of FERC's PURPA rules. The text of the provision is:

(i) Federal Contracts - No contract between a Federal agency and any electric utility for the sale of electric energy by such Federal agency for resale which is entered into after the date of the enactment of this Act may contain any provision which will have the effect of preventing the implementation of any rule under this section with respect to such utility. Any provision in any such contract which has such effect shall be null and void.

The term 'federal agency' means an executive agency (as defined in section 105 of title 5 of the United States Code (PURPA, Section 3(7)).

\section{Competitive Bidding}

Competitive bidding refers to a process whereby many sellers compete with each other to market energy and/or capacity to an electric utility. Energy services may be provided by either supplyside resources (generating facilities) or demand-side resources (conservation and load management). Bidding is one pathway the utility may follow to achieve the least-cost planning goal of acquiring the resource mix with the best combination of expected costs, while minimizing developmental risks and adverse environmental impacts.

The process of compstitive bidding begins when a utility identifies the need for new capacity. Well in advance of the date it begins to accept competitive bids, a utility typically publicizes the quantity and desirable attributes of its needed capacity, the terms of the offer to purchase capacity, participation criteria, and bid evaluation criteria.

Competitive bidding may affect PURPA development in several ways. Competitive bidding would likely affect the price paid for PURPA resources and therefore the return a PURPA de- 
veloper receives. For example, a developer wishes to build a QF. If the utility were to pay the developer a rate based on an administratively-determined avoided cost, the developer might receive a favorable return. However, if the rate were to be set through competitive bidding, the developer could conceivably eam a lower retum. Incentives for developing PIRPA resources would be reduced. On the other hand, in a diffurent situation, competitive bidding could increase the prices paid for non-utility generated power, thereby positively affer,ting the development of PURPA resources.

The actual influence of competitive bidding on price depends heavily on how market forces replace administratively-set avoidect costs and on what combination of least-cost resources are developed. For example, competitive bidding could lower a utility's marginal cost of electricity, resulting in higher profits. This improved profitability might lead the utility to purchase more power from PURPA resources, as long as the cost of those resources remains lower than the ccst of utility-developed resources.

Hydropower developers, whether a PURPA developer or successful competitive bidder, will need transmission access to deliver their product. PURPA only requires that utilities give transmission access to QF developers within the utility's own service area. Thus, if rules goveming wheeling are not changed and if provisions are not made for transmission and wheeling, the competitive bidding market will be severely limited since utilities might receive bids only from resources located within their own service areas. This would likely act to restrict development of PURPA resources and would surely have a very negative effect on development of hydropower resources which, for the most part, are localed in rural areas.

Within the last two years competitive bidding has become established as the way to acquire new energy supplies in the Northwest. Bidding was adopted in Washington in 1989 and in Oregon in 1991. Idaho's and Montana's regulatory commissions have not adopted bidding but it is under discussion in Montana.

This emergency of competitive bidding resulted in 1991s rush to market of five Request for Proposals (RFPs). Montana Power Company (MPC), Puget Sound Power \& Light Company, Bonneville Power Administration (BPA), Pacific Power, and Washington Water Power released RFPs for the acquisition of 595 to $699 \mathrm{MWa}$.

Pacific Power's RFP preceded commission action in Oregon. The process adopted by BPA in early 1991 is like bidding with competitive negotiations. BPA's first competitive solicitation was part of their Billing Credits program and confined to utility respondents, although they could sponsor QF projects.

\section{Regional Institutions}

There are two regional institutions in the Pacific Northwest that affect hydropower development. They are the Northwest Power Planning Council (NPPC) (created by the Northwest Power Act, 
P.L. 96-501, 94 stat. 2967; 16 USC 839-839h) and the region's federal power marketing agency, the Bonneville Power Administration (BPA). The NPPC is a planning authority. BPA provides power marketing and transmission services.

The institutions are closely linked. The NPPC was created by the Northwest Power Act, P.L. 96501, 94 stat. 2967; 16 USC 839-839h. The Northwest Power Act's second and third resource priorities are "renewable resources" and "resources utilizing waste heat or generating resources of high fuel conversion efficiency." (Section 4(e)(1)) Also, Section 6(e)(1) says the BPA "Administrator shall, to the maximum extent practical,...(use his authority)...to acquire conservation...and renewable resources...and to provide credits and technical and financial assistance for the development and implementation of such resources..." The following definitions from Section 3 of the Act apply to most $\mathrm{QF}$ technologies, whether the power is for sale or on-site use.

(16) "Renewable resource" means a resource which utilizes solar, wind, hydro, geothermal, biomass, or similar sources of energy and which either is used for electric power generation or will reduce the electric power requirements of a consumer, including by direct application.

(19) "Resource" means -

(A) electric power, including the actual or planned electric power capability of generating facilities, or

(B) actual or planned load reduction resulting from direct application of a renewable energy resource by a consumer, or from a conservation measure.

All BPA-acquired resources must be cost-effective. The Act's cost-effectiveness standard is defined in Section 3 and appears below. On a conceptual basis, it is similar to PURPA's avoided cost standard as defined in 18 CFR 292.101(a)(6) and applied by 18 CFR 292.304.

(4)(A) "Cost-effective", when applied to any measure or resource referred to in this Act, means that such measure or resource must be forecast -

(i) to be reliable and available within the time it is needed, and

(ii) to meet or reduce the electric power demand, as determined by the Council or the Administrator, as appropriate, of the consumers of the customers at an estimated incremental system cost no greater than that of the least-cost similarly reliable and available alternative measure or resource, or any combination thereof.

(B) For purposes of this paragraph, the term "system cost" means an estimate of all direct costs of a measure or resource over its effective life, including, if applicable, the cost of distribution and transmission to the consumer and, among other factors, waste disposal costs, end-of-cycle costs, and fuel costs (including projected increases), and such quan- 
tifiable environmental costs and benefits as the Administrator determines, on the basis of a methodology developed by the Council as part of the plan, or in the absence of the plan by the Administrator, are directly attributable to such measure or resource.

(C) In determining the amount of power that a conservation measure or other resource may be expected to save or to produce, the Council or the Administrator, as the case may be, shall take into account projected realization factors and plant factors, including appropriate historical experience with similar measures or resources.

\section{Northwest Power Planning Council (NPPC)}

The NPPC has three missions, all of which affect QFs. They are the Power Plan, Fish and Wildlife Program, and Public Involvement Program. The regional Power Plan is periodically published by the NPPC. In it are forecasts of loads, evaluations of resources, a preferred supply strategy, and an action plan. The plan says how the renewable resources priority should be put into effect. The priorities will be important in determining how BPA acquires new resources. Except for conservation, the priority guides choices that cost the same. Conservation has a 10 percent cost advantage. Program directives are defined in the action plan, many of which address renewable resources issues. Resolving the issues can facilitate $\mathrm{QF}$ development.

The 1986 plan addresses the need for BPA to acquire the capability of generating resources. Item 7 of the action plan set the following objective for BPA:

Develop an acquisition process and supporting activities designed to encourage the development of cost-effective priority resources, including conservation, renewables and high-efficiency resources, and lost opportunity resources, while also developing the capability to acquire conventional resources, when and if needed.

A number of activities were given to achieve the objective. Key among them, for QFs are:

...Develop a comprehensive acquisition process. An important part of any process to acquire resources is the purchase price of the resource. The concept, embodied in the Public Utility Regulatory Policies Act, of offering to pay the "avoided cost" (or what would have been paid for the development of the next planned resource), for qualified resources has been effective at encouraging the development of dispersed and renewable resources. Bonneville's acquisition process should embody this concept. Offering prices should be based upon the present value of these resources to Bonneville, including the effects of expected loads put on Bonneville by investor-owned utilities, and should consider characteristics of prospective resources which affect this value, such as dispatchability, and whether acquisition is constrained to a certain time period (a lost opportunity resource). Offering prices should be periodically adjusted to reflect changing demand forecasts, contracted loads and other conditions. The offer should include conditions to ensure that resource development is consistent with requirements of the plan and the Northwest Power Act. 
Develop and demonstrate general approaches to contracting with utilities and independent power developers. When the region needs power, it is quite likely that utilities will not be the only developers of resources. Independent developers will likely sponsor many dispersed generating resources, conservation resources and, possibly, central station power plants. The intent of this activity is to encourage the orderly development of small-scale and high priority resources and to identify and acquire lost opportunity resources as these become cost-effective.

\section{Bonneville Power Administration}

The BPA is the Northwest's federal power marketing agency. In this role it supplies most of the electricity that customer-owned utilities (COUs) sell retail customers. In fact, most utilities throughout the region obtain at least some power from BPA. BPA supplies 48 percent of the region's power. The regional transmission grid is nperated by BPA and transmission services are extensively used by utilities. To some extent transmission services are also available to QFs.

The Northwest Power Act expanded the role of BPA in the region. Prior to the Act, BPA's main function was to distribute generation from federally-owned dams. Now, BPA is involved in many activities that affect QFs. BPA has sponsored numerous studies of renewable resources throughout the region. Resources and technologies that have been studied include hydropower, wind, cogeneration, geothermal, and municipal solid waste. The results of these activities should be of interest to $\mathrm{QF}$ developers.

In response to the NPPC's Power Plan, BPA is working on a resources acquisition policy and program. When fully implemented, the BPA acquisition process will be one way for resource developers to market the output from renewable resource generation projects. Section 6 of the Northwest Power Act covers resources acquisition and the process will need to conform to the Act. The first BPA competitive acquisition process calling for the purchase of resources was announced in 1991. 


\section{Permit Summary Sheet IDAHO}

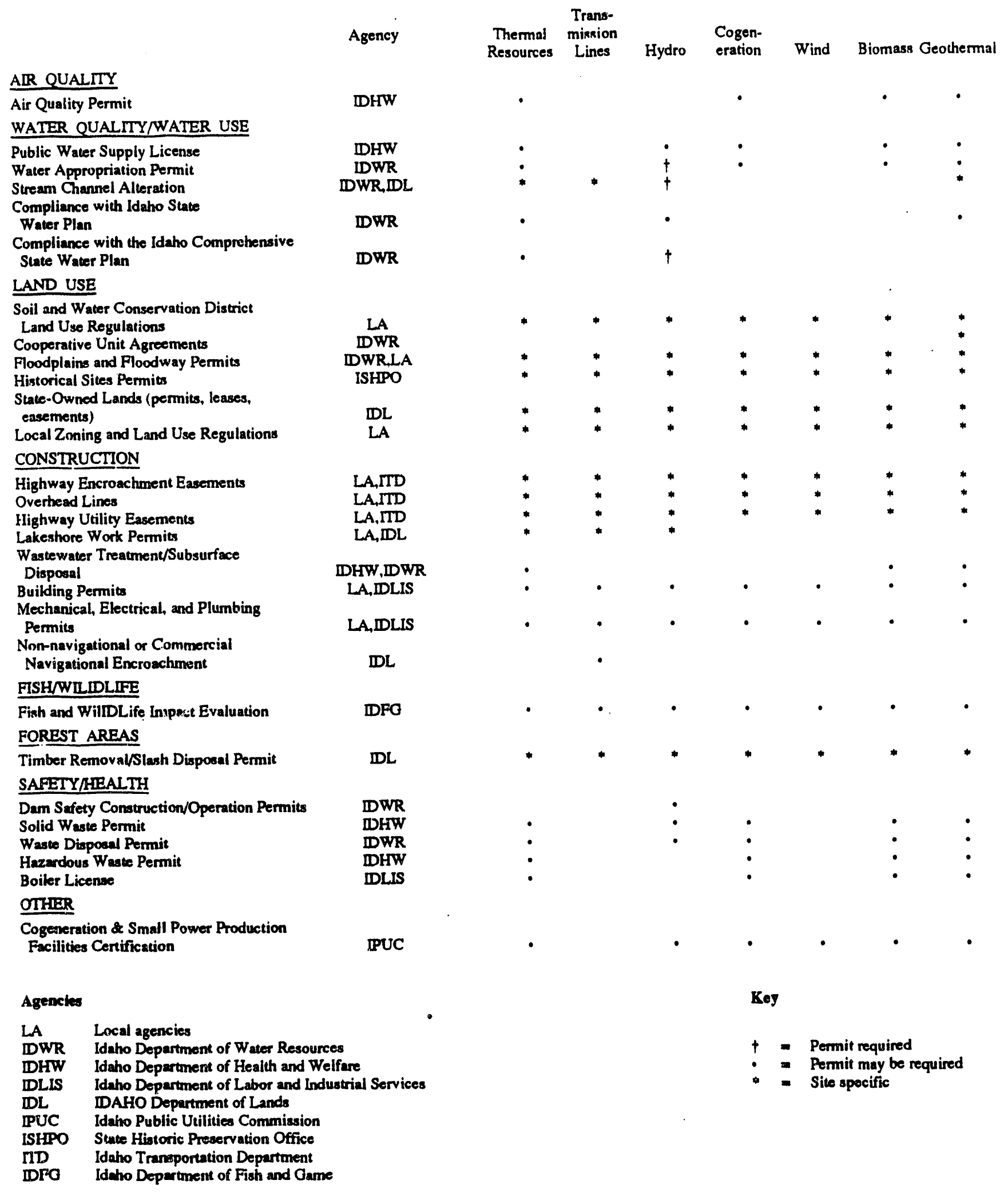




\section{Chapter 2 \\ The Idaho State Process}

\section{Idaho State Agencies' Responsibilities}

The concerns, policies on intervention, and possible mitigative measures that may be required by state agencies for projects located in Idaho are described below for various state agencies.

\section{Agency: Idaho Department of Water Resources (IDWR) Statutory Authority: Idaho Code, Title $\mathbf{4 2}$}

The Idaho Department of Water Resources (IDWR) administers regulatory programs with permit requirements directly applicable to small hydroelectric projects; the water appropriation permits program; and the dam safety program. IDWR has several other public service oriented programs that are also applicable to small hydroelectric development.

\section{Water Appropriation Permits}

A water right allows use of a certain amount of ground or surface water for a specified use during a definite time period. The permit sets a priority or time of the title-holder's first application for water. A water right for power purposes according to Idaho law (Section 42-202 of the Idaho Code) can be initiated only by filing an application for a permit to divert (or use) ground or surface water.

Once IDWR approves an application, a permit is issued and use of the water can begin. The permit holder has up to 5 years to develop the water resource and complete his or her project. At the end of the development period, the permit-holder must submit proof of beneficial use. However, if the project is partially completed, an extension of time for an additional 5 years can be requested. IDWR may issue a license for the water right.

A properly filled out application form submitted with a required fee starts the water right permir process. IDWR supplies application forms and assistance in completing the form. The fee required varies with the rate of flow or water storage volume requested. For example, the filing fee for a 10 cubic feet per second (cfs) appropriation presently costs $\$ 225$. Section 42-205 of the Idaho Code requires that if existing irrigation facilities are to be used for hydropower development, approval by the owner of the facilities is a prerequisite to approval of a water right application. In addition, Section 42-206 of the Idaho Code requires that appropriations of water for power purposes can only be made by "bona fide residents" of Idaho or corporations or partnerships organized or qualified to do business in and under the laws of Idaho. An affidavit that documents and verifies ownership of any irrigation facilities and residency must, therefore, be submitted to support the filing. Certain project details, project costs, and a financial statement from the applicant may also be required. 
Upon acceptance of the proper form and fee, IDWR will advertise the application as a legal notice. The legal notice will be published for 2 consecutive weeks in a generally distributed newspaper in the county of the point of water diversion to notify residents of the area of the possible increased use of water in their area. At this point, a protest against the approval of the advertised permit may be filed with IDWR by area residents. If a water user or other affected person believes that a new appropriation of water may injure his prior water right or other interest, he may file a protest with IDWR within 10 days of the last date of publication of the legal notice advertising the new application.

IDWR always attempts to resolve the differences between parties by means of an informal conference, and finds that most protests can be settled in this manner. If the issues cannot be resolved during the conference IDWR may take testimony in a formal hearing format.

Five criteria, specified in Section 42.203 of the Idaho Code, must be evaluated by the Director of IDWR before making a decision on any application (whether protested or unprotested). They are the following:

1. That the application will not reduce the quantity of water available under existing water rights;

2. That the water supply itself is sufficient for the purpose for which it is being appropriated;

3. That it appears to the satisfaction of the Director of IDWR, that the application is made in good faith and not for delay or speculative purposes;

4. That the applicant has sufficient financial resources with which to complete the proposed work;

5. That the project will not conflict with the local public interest (the local public interest is defined as the "affairs of the people in the area directly affected by the proposed use").

An application for a permit may be (1) approved, (2) approved with conditions, or (3) denied. The Director's decision may be appealed to the district court by any dissatisfied party. IDWR normally withholds final approval of water right applications until coordination of permit issuance is completed with the Idaho Public Utilities Commission and the Federal Energy Regulatory Commission.

The issuance of a permit allows the permit-holder to start the construction that will put the water appropriated to a beneficial use. A permit is issued for a maximum development period of 5 years with the possibility of one extension of time of up to 5 years to complete a project. If delayed by legal action or federal government clearances, it is possible to get additional extensions. Within the permit period, the permit-holder must complete the construction of the planned project and put the water to a beneficial use. If this does not occur within the permit period, the permit may lapse. When the project is completed, the permit-holder must file proof of beneficial use along with the required examination fee. IDWR will then inspect the use of the water and is- 
sue a license. Idaho law (Section 42-203B of the Idaho Code) now requires that hydropower be subordinated io other uses and that licenses can be lost through abandonment or through forfeiture by not using the water for a period of 5 years or more.

Obtaining a water right permit eliminates the need to get a separate permit from IDWR to authorize the alteration of the stream channel for construction of the diversion works. Section 42-3802 of the Idaho Code requires that anyone holding an approved water right permit is authorized to install the necessary works to alter a stream channel for development of a water resource project. However, stream alterations not directly associated with diversion require a separate permit.

Finally, for reservoir project storing more than 10,000 acre-feet of water, the approval of the Idaho Water Resources Board is required in addition to the approval of IDWR.

\section{Dam Safety}

The second IDWR regulatory program that directly affects small hydroelectric projects is the Idaho Safety of Dams Act. The purpose of IDWR's dam safety program is to protect downstream life and property by regulating the construction, maintenance, and operation of Idaho dams. Section 42-1712 of the Idaho Code requires that the approval of IDWR be obtained before building a dam. For purposes of Idaho law, a dam is defined as any embankment that is 10 feet in hydraulic height (measured from the downstream toe to the maximum water level) or any impoundment that has or will have $\mathbf{5 0}$ acre-feet or more. Idaho law requires that if the height of the dam is more than 20 feet, or if an impoundment will contain 100 acre-feet or more, plans and specifications prepared by a professional engineer licensed in the state of Idaho must be submitted for review and approval in addition to the application to construct the dam.

A dam safety application must be submitted on forms provided by IDWR and accompanied by the required fees. The fee depends upon the volume of water to be stored. Upon receipt of the application and associated plans and specifications, IDWR's technical staff will review the project plans to ensure conformance with minimum standards adopted by the Idaho Water Resources Board and to ensure that the planned dam meets good state-of-the-art engineering practices.

After approval of the plans and specifications, the dam owner is authorized to begin construction. The construction must be supervised by an engineer and is subject to periodic inspections by Idaho Department of Water Resources personnel. Any design changes required must be approved by IDWR. As-built plans will be required upon completion of construction.

After completion of the project and after IDWR's final inspection of the completed project, a certificate of storage will be issued if the structure is found to be satisfactory. A storage certificate is usually granted for a period of 2 years. IDWR will make routine biennial inspections and reissue the dam safety certificate every 2 years if the dam continues to be operated and maintained in a satisfactory manner. 
Agency: Idaho Department of Fish and Game (IDFG)

Statutory Authority: Idaho Code, Title 36

The Idaho Department of Fish and Game (IDFG) is responsible for protecting and enhancing fish and wildlife populations and the habitats necessary to sustain those populations. The environmental considerations that must be addressed by hydro developers include the following:

1. Water Quality - Impounding water, especially water containing domestic wastes or agricultural runoff, can cause water quality problems such as algal blooms, decreased dissolved oxygen content, increased water temperatures, increased turbidity or increased unionized ammonia levels. The water quality standards set by the Idaho Department of Health and Welfare address these concerns with respect to both fisheries and human needs.

2. Wildlife - Loss of habitat and interference with migration are possible impacts of hydroelectric development on wildlife. Fluctuating water levels could also affect the reproductive success of some species of water birds.

The IDFG may require impact mitigation measures that can affect the design, construction, or operation of a project. It is advisable for projects involving a significant environmental impact to retain an expert environmental consultant to gather necessary information and recommend mitigative measures. Agencies themselves also have environmental specialists who can assist in determining information is needed.

\section{Agency: Idaho Department of Parks and Recreation (IDPR)} Statutory Authority: Idaho Code, Sections 67-4201 through 67-4301 et seq.

The Idaho Department of Parks and Recreation (IDPR) is charged with the responsibility of reviewing proposed hydropower projects for their positive or negative impacts on recreation. They can impose conditions to enhance the recreational potential of a stream or adjoining land, or they can impose mitigative measures to lessen adverse impacts.

\section{Agency: Idaho Department of Lands (IDL)}

\section{Statutory Authority: Idaho Code, Sections 47-701 et seq., 47-1601 et seq., Title 58}

If state land is involved in a proposed hydroelectric development, either for the power plant, road access, transmission line right-of-way, or pipelines for transporting water, necessary use permits and leases must be negotiated through the Idaho Department of Lands (IDL).

Whenever construction occurs below the mean high water mark of a river or encroaches on other state lands, an easement must be secured through the IDL. A fee is charged dependent on the land's fair market value. 
In addition to the one-time consideration and application fee, there will he an annual payment for an easement for small hydroelectric projects on state endowment lands and state submerged lands, based on the following formula:
ANG $\times 2$ mills $\times P$
Where:
ANG $=$ annual net generation in kilowatt hours
2 mills $\quad=2 / 10$ of a cent
$\mathrm{P}=$ percentage of the hydroelectric project on state land

The Board may make a proportionate increase in the annual consideration if the grantee receives an increase in compensation for energy produced.

The grantee will submit a verified copy of the annual net generation, along with the annual consideration, which will be due and payable on or before February 1 of the following year. If the annual consideration is not paid on or before February 1, the department will give written notice to the grantee that if payment of the annual consideration and interest thereon, accruing from February 1 at a rate set annually by the Board, is not received within 60 days of notice thereof. the Board may cancel the easement without further notice.

The consideration for easements for all hydroelectric projects other than small projects shall be determined by the Board on a case by case basis.

The term of an easement for all hydroelectric projects on state endowment lands and state submerged lands will not exceed the term of the federal license authorizing the project or the term of the purchase contract that the grantee has with an electric utility, whichever term is less.

\section{Agency: Idaho Department of Health and Welfare (IDHW) Statutory Authority: Idaho Code, Section 39-3601 et seq.}

As required by the Clean Water Act, applications for hydropower licensing must obtain certification that the proposed project will not cause any violation of state water quality standards. In Idaho, certification can be obtained from the Bureau of Water Quality of the Division of Environment of the Idaho Department of Health and Welfare (DHW). Water quality standards are not the same for all streams in the state, and clarification of the appropriate standards should be obtained prior to application. Authorization for temporary violation of water quality standards, as would likely occur during construction, must also be obtained. 


\section{Agency: Idaho Department of Water Resources (IDWR), Energy Division}

Statutory Authority: Executive Order \#76-4; Executive Order 80-10

The Idaho Energy Division was created in February 1974. The office originally functioned as part of the Governor's Office. Subsequently, it was transferred to the Public Utilities Commission, but again was transferred back to the Governor's Office by Executive Order 76-4 in 1976.

In 1981, through Executive Order 80-10, the Idaho Office of Energy merged with the Idaho Department of Water Resources. The newly-formed Energy Bureau existed until 1989, at which time it was elevated to division status.

The Energy Division's mission places emphasis on energy conservation activities and the use of renewable resources.

\section{Agency: Idaho State Historic Preservation Office (ISHPO) Statutory Authority: Idaho Code, Sections 67-4101 et seq. and 67-4601 et seq.}

State and federal law protects historical and archaeological sites as well as National Register properties. The Idaho State Historic Preservation Office (ISHPO) has responsibility for reviewing the impacts of proposed projects and any avoidance, mitigation, or protective measures proposed by the applicant. A report on the cultural resources located in the project area must be included in the license or exemption application. Assistance in preparing this report can be obtained from the ISHPO.

\section{Agency: Idaho Public Utilities Commission (IPUC) Statutory Authority: Idaho Code, Title 61}

For several reasons, the Idaho Public Utilities Commission (IPUC) should be contacted during the preparation of an application. First, the IPUC has jurisdiction over the prices paid by investor-owned utilities for power purchased from electric generating facilities, and over the rates and charges levied by investor-owned utilities on hydroelectric facilities for interconnection, line maintenance, and the supply of back-up power. Second, the IPUC can help identify the utilities that might be possible buyers of new electrical energy. Contracts between a small power producer and a regulated utility must be approved by the IPUC.

In Idaho the term "public utility" includes: ... every common carrier, pipeline corporation, gas corporation, electrical corporation, telephone corporation, telegraph corporation, motor corporation, and wharfinger, as those terms are defined in this chapter and each thereof is hereby declared to be a public utility and to be subject to the jurisdiction, control, and regulation of the commissions and to the provisions of the act: provided that the term "public utility" as used in the act shall cover cases both where the service is performed and the commodity delivered directly to the public or some portion thereof, and where the service is per- 
formed on the commodity delivered to any corporation or corporations or any person or persons, who in tum, either directly or indirectly or mediately or immediately, perform the services or delivers such commodity to or for the public or some portion thereof (C.61-104).

Public Utility Regulation also requires a Certificate of Convenience and Necessity (ID Code Section 61-526). Before a street railroad corporation, gas corporation, electrical corporation, telephone corporation, or water corporation begins constructing a street railroad or a line, plant, system, or extension, it must first obtain from the Commission a certificate that the present or future public convenience and necessity require or will require such construction.

The Idaho Public Utilities Commission (IPUC) has been very supportive of small power producers and has been an early leader in implementing the Public Utilities Regulatory Policies Act (PURPA). While no standard contract form is enforced, the IPUC has encouraged Idaho utilities to bargain in good faith with small power producers. Recent reformulation of the avoided cost schedule formula that depends only on actual energy output (rather than capacity), recognizes that the value of a kilowatt hour is seasonal in character. The exact payment, which has an upward adjustment factor for contracts in future years, may be crucial to the economic profitability of any renewable energy production.

\section{Agency: Idaho Transportation Department (ITD) Statutory Authority: Idaho Code, Title 49}

When a project requires construction of a new road that connects with an existing highway, an approach permit must be obtained from the Idaho Transportation Department (ITD). Some existing roads are not under the jurisdiction of the state and a permit may be required from a local highway district. The ITD can let you know who has jurisdiction. Permits will also be required if a project requires the operation of oversize or overweight vehicles on highways.

Commercial Vehicle Licenses - Special vehicle licenses are required for any commercial vehicle.

Temporary Trip Permit - This is required for all commercial vehicles licenses in other states and operating in Idaho. Permits can be purchased at ports of entry and other truck checks within the state for $\$ 12$ plus a fee based on combined gross weight and mileage.

Oversize Permit - Without an oversize permit, maximum width for a commercial vehicle is $8 \mathrm{ft} 6$ in. wide, $14 \mathrm{ft}$. high, $48 \mathrm{ft}$. long on a single trailer or $60 \mathrm{ft}$. long on a double trailer, unless the overall length including the coupling is $75 \mathrm{ft}$. or less. An extra length permit costs $\$ 25$. This is an annual permit. Some roads cannot be traveled by an oversize vehicle.

Overweight Permit - Normal permitted weight for a commercial vehicle is $80,000 \mathrm{lbs}$. An extra weight permit costs $\$ 10$ annually, but does not allow the holder to exceed the legal access weight (weight per axle). Some roads cannot be traveled by an overweight vehicle. 
Right-of-Way Access Permit - New driveways or roads taking access from a state highway require a permit certifying they will not interfere with traffic flow on the road. Granting of the permit will depend on the access control established for the state road. A fee of about $\$ 40$ is charged for this permit.

Utility Permit - Utility permits are obtained from ITD to install utilities in the public right-ofway of a state highway by the private contractor on the job.

\section{Idaho State Permitting and Licensing Requirements}

\section{Water Quality/Water Use}

\section{Permit or Regulation: Water Appropriation}

Statutory Authority: Idaho Code, Section 42-202-42-222

Agency: Idaho Department of Water Resources (IDWR)

A water right allows use of a certain amount of ground or surface water for a specified use during a definite time period. The permit sets a priority or time of the title-holder's first application for water. A water right for power purposes according to Idaho law (Section 42-202 of the Idaho Code) can be initiated only by filing an application for a permit to divert (or use) ground or surface water.

In order to protect groundwater resources from over-exploitation, Idaho law allows for two area designations that limit groundwater appropriation within a designated area.

(A) "Critical groundwater area" is defined as any groundwater basin or designated part thereof, not having sufficient groundwater to provide a reasonably safe supply for irrigation of cultivated lands, or other uses in the basin at the then current rates of withdrawal, or rates of withdrawal projected by consideration of valid and outstanding applications and permits (Idaho Code § 42-233a).

If an application for permit is made in an area that has been designated as a critical groundwater area, the Director of IDWR may deny the application if it is believed that insufficient water is available subject to appropriation at the proposed well. This belief may come from the investigation of the application, or from investigation made in determining the area to be critical, or from other information. If groundwater at the location is available in a lesser amount than that applied for, the Director of IDWR may issue a permit for the use of the water to the extent that the water is available for appropriation. 
(B) A "groundwater management area" is a groundwater basin that the Director of the IDWR declares is approaching the condition of a critical groundwater area. The critical groundwater area designation may be used to justify denial of a groundwater permit (Idaho Code § 42-233b).

Application for permits made within a groundwater management area are approved by the Director only after he has determined on an individual basis that sufficient water is available and that other prior water rights will not be injured.

\section{Permit or Regulation: Stream Channel Alteration \\ Statutory Authorization: 42 Idaho Code 38}

Agency: Idaho Department of Water Resources (IDWR)

Any action to be taken that will modify the channel of a continuously flowing stream below the mean high water mark will require a Stream Channel Alteration Permit.

The application will be evaluated on the following:

- The need for the proposed action in the waterway and any alternative methods of meeting the need;

- The stability of the altered condition and its impacts on adjacent lands (i.e., flooding and erosion);

- The impact of the change on fishery habitat, water quality, recreation, and aesthetic values;

- Modification of the proposal that would diminish or eliminate harmful effects of the action in the waterway.

The application must be submitted on a standard form and must include maps, plans, and specifications for the activity related to its effect on the stream channel.

If a 404 Permit must be obtained from the U.S. Amny Corps of Engineers and/or a special permit or easement obtained from the Department of Lands, a joint application for the permits can be filed with the IDWR and copies will be sent to the other agencies involved. Each agency will, however, proceed with its own evaluation. The IDWR will serve as coordinator and ensure that the applications move through the process.

IDWR will send copies of the completed application to its appropriate regional offices as well as the interested agencies for review and comment. A public hearing may be held at the Department's discretion. Non-controversial projects will normally receive a permit within 60 days of submittal. Controversial projects can take considerably longer. 


\section{Permit or Regulation: Public Water Supply}

Statutory Authority: Idaho Code Section 39-118

Agency: Idaho Department of Health and Welfare (IDHW)

The Idaho Department of Health and Welfare (IDHW) requires that plans and specifications for the construction of any new, modified, or expanded drinking water systems must be approved by the Divisicn of Environmental Quality (DEQ). This includes piping that delivers water for consumption by 10 or more premises, or 25 or more people for at least 60 days a year (or other systems designated by the Director or having a public health significance). Developers of smaller water systems should contact their local District Health Department.

Plans and specifications submitted to the IDHW must be prepared and certified by a professional engineer licensed to practice in Idaho. When the construction is complete certified as-built plans must also be submitted to the IDHW. In lieu of as-built plans the engineer of record may certify that the facility was constructed according to the approved plans. To achieve that requirement, the engineer of record must be hired to inspect the project while it is being constructed. If the engineer is not hired, or is released from the job, the engineer is required to inform DEQ.

The purpose of engineering reviews is to ensure that public health and water quality are protected by using accepted construction practices and materials. Water quality engineers make every reasonable effort to complete reviews as promptly as possible, generally within 30 to 45 days. Reviews are scheduled on a first come-first served basis.

\section{Permit or Regulation: Compliance with the Idaho State Water Plan Statutory Authority: Idaho Constitution Article 15, Section 7, Idaho Code Section 42-1831 Agency: Water Resource Board (Board)}

Anyone wishing to use surface waters or groundwaters for beneficial purposes is required to obtain a water right. In order for a water right to be granted, the proposed use must be in compliance with the Idaho State Water Plan. The purpose of the plan is to guide the development, management, and use of the state's water and related lands. The plan states the objectives of the Water Resource Board (Board) and establishes policies which will guide future water usage. In most cases, the policies are not specific enough to directly relate to individual projects that may be proposed. However, minimum streamflows are established for the Snake River which could directly affect proposed projects.

These reviews ensure that future water resource uses will complement and supplement state goals, which are directed toward achieving a quality of life for the citizens of Idaho. The plan recognizes past actions, addresses present conflicts, and identifies future opportunities.

Review by the Water Resource Board is triggered by making a water appropriation application. If a proposed project has some potential for conflict with the state water plan, the Director can recommend review by the Board. 
The time required for processing will usually be commensurate with the scope of the projest be ing proposed. Small projects generally will not require review for compliance with the water plan. However, the review process for a major project could take several months.

\section{Permit or Regulation: Compliance with the Idaho Comprehensive State Water Plan Statutory Authority: Idaho Code Section 42-1734 et seq. Agency: Water Resource Board (Board)}

The comprehensive state water plan's purpose is to plan for conservation, development, management, and optimum use in the public interest of all unappropriated water resources and waterways of the state. The plan contains a description of existing and proposed uses, and the impact of such uses at the local, state, and regional level. The plan quantifies, insofar as possible, the unappropriated waters of the planning area and plans the allocation of such waters among the various competing uses.

As part of the plan, selected waterways have been designated as protected rivers. Protected rivers can be either natural or recreational rivers. A natural river is a waterway which possesses outstanding fish and wildlife, recreation, geologic, or aesthetic values. The waterway is free of substantial man-made impoundments, dams, or other structures and of which the riparian areas are largely undeveloped, although accessible in places by trails and roads. A recreational river is similar to a natural river, except that it might include some man-made development within the waterway or within the riparian area of the waterway.

Proposed projects would be evaluated for their effect on fish and wildlife, recreational, aesthetic, historical, cultural, natural or geologic values of the waterway. For rivers designated as natural, the following activities are prohibited:

- construction or expansion of dams or impoundments

- construction of hydropower projects

- construction of water diversion works

- dredge or placer mining

- alterations of the stream bed

- mineral or sand and gravel extraction within the stream bed

In designating a recreational river, the Water Resource Board (Board) will determine which of the activities listed above shall be prohibited, and may specify the terms and conditions under which activities that are not prohibited may go forward.

Review for compliance with the comprehensive state water plan is triggered by filing a water rights application. If the Director determines a proposed project has some potential for conflict with the state water plan, review by the Board may be recommended.

Since review is concurrent with review of a water appropriation permit, the processing time can vary depending upon whether protests are filed against the permit application. Because the plan 
is more restrictive with regard to natural rivers, processing should be relatively quick. However, since the Board may need to develop terms and conditions for projects on recreational rivers, processing times will be longer.

\section{Permit or Regulation: 404 Permit}

Statutory Authority: 33 United States Code 401-1241; 33 CFR 320 and 322 through 329

Agency: U.S. Army Corps of Engineers (COE); Idaho Department of

\section{Water Resources (IDWR)}

Construction of structures within, dredging, and filling of navigable waters or wet lands as classified by the Corps of Engineers (COE) requires a 404 Permit. These are permitted by the COE, depending on the complexity of the activity. General, Regional, and Nationwide Permits allow more common, generic types of activities without formal evaluation. The individual permit must be obtained for larger, more unusual actions that could result in major impacts to the waterway.

The basis for evaluating the permit application include effects of the activity on:

- the public interest and use of the water way resource

- the resources of wet lands

- fish and wildlife

- water quality

- historic, cultural, scenic, and recreational values

- adjacent properties or water resource projects

- other federal, state, or local requirements

- flood plain management

- water supply and conservation

- energy conservation and development

- navigation

The availability of alternative methods that would result in less harmful effects is also an important consideration.

A standard form must be completed and submitted together with maps, plans, and specifications for the activity relating to its effect on the waterway and/or wetlands. If a Stream Channel Alteration Permit and/or State Land Easement or Special Permit is required for the activity, a joint application for the permit can be filed with the IDWR and copies will be sent to the other agencies. The IDWR will coordinate the process of the permit application.

Upon receipt of the completed application, the regional COE office will publish a public notice of the applications and request input from regulating agencies, individuals, and interest groups within a 15 to 30 day period. Substantial objections will result in a public hearing. Objections from public agencies must be resolved before the permit can be issued.

Most permits will bะ issued within 60 days of application, although controversial projects may take 120 days or longer. 
Permit or Regulation: National Pollution Discharge Elimination System (NPDES)

Statutory Authority: 33 United States Code 1251; 40 CFR 125

Agency: Idaho Department of Health and Welfare (IDHW); U.S. Environmental

Protection Agency (EPA)

The owner/operator of any proposed activity that will discharge wastewater into surface waters by way of a discrete conveyance (pipe, ditch, etc.) must first obtain a National Pollution Discharge Elimination System (NPDES) Permit. A separate application is required for each facility in the operation discharging separately.

The NPDES permit process addresses the amount of pollutants to be discharged to surface waters. Important considerations include the content of the process effluent, proposed treatment prior to discharge, and the particular body of water into which the discharge will be made.

For most operations, "best management practices" including schedules of activities, prohibitions or practices, maintenance procedures, and other management practices to prevent or reduce the pollution of surface waters, must be implemented. Monitoring and reporting of discharge is required, as is annual reporting of compliance with the regulations.

Applicants are to register with EPA and the Idaho Department of Health and Welfare (IDHW) at least 180 days prior to construction of the proposed operation. Information to be submitted includes:

- information about the owner, operator, and facility;

- proposed treatment for processing wastes;

- description of proposed runoff storage facility, including area drained, capacity, and design safety considerations;

- measures to divert flowing surface water;

- a sketch of the operation showing relation to surface water;

- an operational plan to ensure compliance with the permit requirements.

The basis for evaluation of an NPDES application by EPA staff is 1) adherence to EPA specific effluent guidelines; 2) state water quality standards for the specific body of surface water; and 3) water quality certification performed by the state.

After the requirements and conditions for granting the permit have been developed, a 30-day public notice is given during which any objections to granting the permit must be made. Substantial objections could result in a public hearing. Approximate time to process the permit application is 3 to 6 months. 


\section{Fish and Wildlife}

Permit or Regulation: Fish and Wildlife Impact Evaluation

Statutory Authority: Idaho Code, Sections 36-103 et seq.

Agency: Idaho Department of Fish and Game (IDFG)

In Idaho, all wildlife, including wild animals, wild birds, and fish are declared to be the property of the state. The Idaho Fish and Game Commission, acting through the Idaho Department of Fish and Game (IDFG) implements and enforces regulations regarding fishing and hunting and carries out actions to protect and enhance fish and wildlife populations and their habitats.

While regulations and IDFG authority is quite specific with regard to harvest, transport, capture, and management of fish and wildlife populations, IDFG's authority to manage habitat is not as clearly defined.

Since fish and wildlife habitats are generally controlled by state or federal land and water management agencies, the IDFG frequently exercises its influence through the regulatory processes of these agencies. By influencing how habitats are managed the IDFG can effectively manage fish and wildlife populations and the effects that can be caused by any facilities that may be constructed in these areas. To illustrate, the IDFG could act as an intervener in proceedings before other agencies to acquire air, water, waste, or other permits.

There are no permits issued by IDFG to certify that fish and wildlife impacts have been adequately mitigated or do not exist. Nevertheless, because the agency can and will influence various aspects of the project through their actions, developers are strongly encouraged to consult with the agency very early in the planning process. The IDFG will closely coordinate with other agencies as appropriate.

\section{Land Use}

Permit or Regulation: Floodplain Development

Statutory Authority: National Flood Insurance Act of 1968; Flood Disaster Protection Act of 1973; Local County and City Ordinances Agency: Idaho Department of Water Resources (IDWR); Local Governments

The appropriate local authority will review all plans to ensure that any changes proposed or structure to be constructed will not have an adverse effect upon flooding. One key element is that the capacity of streams cannot be changed. Permits will generally be approved within 6 weeks. 
Permit or Regulation: Historical Site Permit

Statutory Authority: Section 106 of the National Historic Preservation Act of 1966;

36 CFR 800 "Procedure for the Protection of Historic and Cultural Properties" Agency: Idaho State Historic Preservation Office (ISHPO)

After being notified of a proposed project, the Idaho State Historic Preservation Office (ISHPO) will check inventory and survey records to determine if surveys have been conducted and whether archaeological sites on historic properties have been identified in the project area.

In some cases, professionals from the ISHPO will inspect a project area to help a private firm or individual comply with federal preservation laws. If a proposed project requiring federal approval or a federal license is not on federal land, is not federally funded, and if it is less than 25 acres in size, the ISHPO will consider inspecting the project at no cost to the applicant.

\section{Idaho Procedures for Review of Federal Projects}

After receiving a notification of a project, the ISHPO will check inventory and survey records to determine if surveys have been conducted and whether archaeological sites or historic properties have been identified in the project area.

Based on the nature of the project and on the project's location, the ISHPO will usually make a standard comment. These comments technically are addressed to the federal agency, even though in some cases the federal agency requires private individuals to obtain ISHPO comments. The potential comments are as follows:

1. Archaeological and historic surveys have determined there are no archaeological or historic properties in the proposed area. The project will have no effect.

2. Based on the nature of the project and its location, it is unlikely the project will affect archacological or historic properties. However, if archaeological materiais (arrow points, bottles, etc.) are found during construction, the ISHPO should be contacted.

3. Based on the nature of the project and its location, it is likely, but not confirmed, that National Register properties occur in the project area and could be affected by the project. The agency should have the area inspected by a professional archaeologist, historian, or architectural historian, as appropriate, to locate and evaluate any archaeological sites and historic properties in the area. This work should follow the Secretary of Interior's guidelines for historic preservation projects.

4. There has been a survey in the area, and archaeological sites or historic properties have been recorded. Following National Park Service standards, the agency should determine which sites or properties are eligible for the National Register.

5. National Register properties will be adversely affected by the project, and the agency should obtain the comments of the Advisory Council on Historic Preservation. 
In some cases, professionals from the ISHPO will inspect a project area to help a private firm or individual comply with federal preservation laws. If a project requiring federal approval or a federal license is not on federal land, is not federally funded, and if it is less than 25 acres in size the ISHPO will consider inspecting the project at no cost to the applicant. The decision depends on available personnel and funding.

Normally 30 days is allowed for the ISHPO to comment on federal projects. If the ISHPO has not commented in this period, the agency can proceed with the Section 106 process. Allowances are made in cases where the normal review period would cause a delay in a project.

\section{Permit or Regulation: State Land Easement Statutory Authority: Idaho Code, Title 58 Agency: Idaho Department of Lands (IDL)}

An easement must be secured whenever construction occurs below the mean high water mark of a river or encroaches on other state lands. A fee is charged based on the land's fair market value. The approximate time to process the permit application is several days to several weeks, depending on the complexity of the project.

\section{Construction}

Permit or Regulation: Highway Encroachment Easements Statutory Authority: State of Idaho Right-of-Way Use Policy 12-450, 12-451 Agency: Idaho Transportation Department (ITD)

Any person or agency planning to access a highway or use a highway right-of-way for any purpose other than travel must obtain an approved "Application and Permit to Use Right-of-Way."

A sketch should be provided by the applicant showing the location of existing and proposed approach changes, location of other proposed work to be done within the highway right-of-way and highway signs in the area of the approach, as well as the costs of studies or appraisals when large development plans must be reviewed and/or extensive Idaho Transportation Department (ITD) time is expected on a traffic study or review. The ITD may require reimbursement for inspection time and travel costs. The intent is to recover TD cost only. The application will not be processed before payment of the nonrefundable application fee.

The ITD reserves the right to make any changes, additions, repairs, or relocation to any approach or its appurtenances within the highway right-of-way necessary relocation, reconstruction, widening, or maintenance of the highway and/or to provide proper protection of life and property on, or adjacent to, the highway.

Application for highway encroachment easements can take several days to several weeks to process, depending upon the complexity of the project. 
Permit or Regulation: Highway Utility Easements

Statutory Authority: Idaho Code, Sections 40-312(3), 62-701, 62-705, 62-1101, $42-3212$

Agency: Transportation Board; Idaho Transportation Department (ITD)

Highway utility easements relate to the manner in which utility installations are to be made within the right-of-way of state highways when such use and occupancy of the highway right-of-way is deemed to be in the public interest, and will not adversely affect the highway or its users.

Utilities must be located to minimize the need for adjustments for future highway improvements, avoid interference with highway maintenance or signing, and permit access to the utilities for their maintenance with minimum interference to highway traffic.

The utility company or independent power developer is responsible for the design of the utility facility to be installed within the highway right-of-way or attached to a highway structure. The Idaho Transportation Department (ITD) is responsible for review and approval of the proposal. with respect to the location of the utility facilities to be installed and the manner of attachment. This includes the measures to be taken to preserve the safe and free flow of traffic, structural integrity of the roadway or highway structure, ease of highway maintenance, appearance of the highway, and the integrity of the utility facility.

Facilities located on or across highways for which deeds of right-of-way have not been obtained (such as through National Forest System lands, U.S. Bureau of Land Management land, etc.) will require a grant of right-of-way for non-highway purposes from the appropriate governmental agency having administration of the lands. Facilities located on or across highways which are located on railroad property will require the approval of the railroad company.

Each new utility installation which is to occupy highway right-of-way requires a permit. The permit must, as a minimum, describe the ITD standards for location, construction, protection of traffic, maintenance, access restrictions, and any special conditions applicable to each installation.

The permit application must include detailed drawings or sketches showing the location of the proposed facility with respect to existing and/or planned highway improvements, the traveled way, horizontal and vertical clearance, the right-of-way lines and, where applicable, the access control lines and approved access points. When attachment to a highway structure is proposed, details of the attachment method must be included for approval by the ITD prior to installation. The permit application must also include traffic control plans for any work to be performed within the highway right-of-way.

When a proposed facility involves a pipeline, the following additional data are required:

1. contents to be transported

2. pipe size, nominal

3. wall thickness
4. location class and construction type

5. design pressure (maximum operation pressure)

6. maximum actual working pressure 
When indicated on the permit, the permittee must take out and maintain property damage and public liability insurance. The permittee may also be required to furnish a surety bond in the amount specified in the special provisions of the permit for installation and future repair, relocation, or removal of the facilities.

\section{Permit or Regulation: Building}

Statutory Authority: Idaho Code, Title 39, Chapter 41

Agency: Idaho Department of Labor and Industrial Services (ILIS)

The issuance of a building permit is based on the compliance of proposed plans with adopted building codes. In some counties, the building permit is administered by the Idaho Department of Labor and Industrial Services (ILIS). Issuance of a building permit for industrial use can be expected to take several weeks after submittal of the building plans.

\section{Permit or Regulation: Mechanical/Plumbing/Electrical Permits} Statutory Authority: Idaho Code, Title 39, Chapter 27; Idaho Code, Title 54, Chapter 10 Agency: Idaho Department of Labor and Industrial Services (ILIS)

Mechanical, plumbing, and electrical permits are based on compliance with state codes and are administered by the state Idaho Department of Labor and Industrial Services (ILIS). The permits are issued directly to the contractor rather than to the owner/operator of the facility being constructed. Issuance of these permits should not take longer than 2 weeks after submittal of the completed application.

\section{Miscellaneous Permits}

\section{Permit or Regulation: Slash Disposal Permit \\ Statutory Authority: Idaho Code Title 38, Chapters 1 and 4 Agency: Idaho Department of Lands (IDL), Board of Land Commissioners}

Any burning operation conducted for the purpose of hazard reduction shall be in accordance with the law requiring burning permits during the closed fire season. Persons conducting buming operations must have sufficient men, tools, and equipment on hand to immediately stop the uncontrolled spread of fire. Burning operations shall be planned, prepared, and executed in such a manner that forest resources are not damaged and air quality standards are met. 
Permit or Regulation: Timber Removal

Statutory Authority: Idaho Code Title 38, Chapters 1 and 4; IDAPA 20.19

Agency: Idaho Department of Lands (IDL), State Board of Land Commissioners

A permit is required from the Department of Lands (DL) for timber cutting on state granted easements or right-of-ways.

Permit or Regulation: Commercial Vehicle, Temporary Trip, Oversize, Overweight, Right-of-Way Access, Utility

Statutory Authority: Idaho Code, Title 49

Agency: Idaho Transportation Department (ITD)

Temporary Trip Permit - This is required for all commercial vehicles licenses in other states and operating in Idaho. Permits can be purchased at ports of entry and other truck checks within the state for $\$ 12$ plus a fee based on combined gross weight and mileage.

Oversize Permit - Without an oversize permit. maximum width for a commercial vehicle is 8'6" wide, 14 ' high, 48 ' long on a single trailer or $60^{\prime}$ long on a double trailer, unless the overall length including the coupling is $75^{\prime}$ or less. An extra length permit costs $\$ 25$. This is an annual permit. Some roads cannot be traveled by an oversize vehicle.

Overweight Permit - Normal permitted weight for a commercial vehicle is 80,000 pounds. An extra weight permit costs $\$ 10$ annually, but does not allow the holder to exceed the legal access weight per axle. Some roads cannot be traveled by an overweight vehicle.

Right-of-Way Access Permit - New driveways or roads taking access from a state highway require a permit certifying they will not interfere with traffic flow on the road. Granting of the permit will depend on the access control established for the state road. A fee of about $\$ 40$ is charged for this permit.

Utility Permit - Utility permits are obtained from ITD to install utilities in the public right-ofway of a state highway by the private contractor on the job.

\section{Local Permit Requirements}

Local governments such as cities, counties, road districts, flood control districts, and drainage districts will have some jurisdiction over hydropower development. A developer should contact city and county planning and public works departments early in the development process. These departments should be able to inform the developer of all local permits the project will require. All local permit requirements must be satisfied prior to, or concurrently with, applications for use and occupancy of federal land and application to the Federal Energy Regulatory Commission for exemption or license. 
The county planning department can inform the developer of any zoning and land use restrictions. Most counties also have planning and zoning commissions that will review project plans for compliance with comprehensive plans, zoning regulations, and needs for conditional or special use permits. Conditional use permits may be required for projects requiring the use of or the crossing of land under county jurisdiction. Generating facilities impacting only the developer's property should encounter few problems. More substantial generating facilities may be referred to hearings before the planning commission or county commissioners to determine if the project is in the public interest.

Counties may also have some jurisdiction over construction in or near defined flood plains and over use of, or construction near, county highways. The county courthouse, the county zoning administrator, and the county highway district are the best contacts for determining what permits or approvals will be required. For those areas under county jurisdiction, building, plumbing, and electrical permits from the public works or building department are generally required. The project plans must be reviewed for compliance with building and electrical code requirements.

If a proposed site is within a city's limits or within its area-of-impact, appropriate contact should be made with city officials regarding building permits, zoning regulations, flood plain construction, and highway usage. Contact the city hall of the nearest city for a determination of the required permits and approvals and jurisdiction.

\section{Determining Which Permits are Required}

To enable a developer to determine what local permits are necessary for a particular site, and for guidance in obtaining local permits, the following guidelines are provided.

- Determine with certainty within what local jurisdiction the project site lies. Assumptions about jurisdiction are often inaccurate. Even if a site is within the county, it is possible it may be within a city's Area of Impact, which would give the city certain jurisdiction over the project.

- Contact agency staff early to obtain information about permits and to discuss your plans. Go into their office in person to make personal contact and to show your commitment to expediting the permitting process.

- Determine what permits will be required for the proposed project; what information should be provided; the process that will be followed; and time frames, including submittal dates, hearing dates, and the time within which a decision can be expected.

- Get copies of the applicable regulations so you can personally review them and the evaluation criteria. Ask questions if the written regulations vary from information the staff has provided. 
- In the case of more discretionary permits, ask the staff about the likelihood of approval: also what might help to speed up the process and decision.

- Submit a complete application. Incomplete applications will result in processing delays.

- Attend all meetings where the application will be discussed. If there is no one to respond to questions, delays may occur or the permit may be denied.

Table 3 contains a list of Idaho permits and approvals that may occur at any local govemment level and the type of agency and department that normally will be the administrator. Smaller communities often issue all permits through a single office, such as the Clerk. In some counties, one or more highway districts exist that are responsible for construction and maintenance of roads. These agencies will be the administrators of all permits/approvals having to do with public rights-of-way.

A number of these permits, mainly those listed as administered by the Planning Department, will involve substantial discretionary action on the part of the decision makers. Approval will be based on conformance of plans with established criteria or standards. Therefore, these decisions will usually be made by elected or appointed officials including city councilmen, county commissioners, or planning and zoning commissioners. Another group of approvals will be based on the adequacy of technical plans. These will generally be the permits listed as being administered by the public works department and building department. Several items will be simply a matter of registration, including the business license and registration of proprietorship. The following is a general description of each of the permits and approvals listed above.

\section{Land Use}

\section{Comprehensive Plan Amendment}

All cities and counties are required by state law (Idaho Code 67-6501) to have a comprehensive plan, establishing goals and policies for development. A project that will conflict with the goals and policies requires the conflict to be eliminated. Such an amendment is a major change in policy, and thus requires public hearings and considerable time, a minimum of 3 months. The process normally requires a written proposal on how the plan should be amended, a public hearing by the Planning and Zoning Commission with a recommendation to the elected body, and a hearing by the elected body prior to a decision. Planning and Zoning Commissions are authorized by law to make such recommendations to the elected body only twice a year. 
Table 3

\section{Local Government Permits in Idaho}

\begin{tabular}{ll}
\multicolumn{1}{c}{ Permits/Approvals } & \multicolumn{1}{c}{$\begin{array}{c}\text { Agency } \\
\text { County/City } \\
\text { Comprehensive Plan Amendment }\end{array}$} \\
Rezoning & Planning Department \\
Special/Conditional Use Permit & \\
Zoning Certificate & \\
Variance & \\
Floodplain Development Permit & \\
Design Review Approval & \\
Sign Permit & \\
Approval of a Private Road & \\
Environmental Impact Evaluation & \\
County Road Access & Public Wórks/Road Department; \\
Approval of Public Road Plans & District \\
Right-of-Way Encroachment Permit & \\
Utility Permit & \\
Permit to Discharge to Public Sewer System & \\
Building Permit & Building Department \\
Occupancy Permit & \\
Plumbing Permit & \\
Electrical Permit & County Commissioners \\
Approval of Solid Waste Permit & Recorder \\
Registration of Sole Proprietorship & \\
or General Proprietorship Business &
\end{tabular}

\section{Rezoning}

Cities and counties are required by state law to have established zoning within their boundaries. Each zone has land uses permitted either outright or by special permit. If the proposed hydroelectric project is not among uses permitted in the designated zone, the zoning must be changed to permit it at that site. A standard form is usually completed for the application. The hearing and approval process is essentially the same as for a Comprehensive Plan Amendment.

\section{Special/Conditional Use Permit}

Land uses that are only permitted within the zone by special or conditional use permit must be considered in a public hearing by the Planning and Zoning Commission or the elected body. Their consideration is to address whether the proposed use is appropriate in the particular location, taking into account surrounding land uses, condition of streets, and other site factors. Conditions on the design and operation of the proposed use can be established in the permit. Minimum time to secure a permit is normally about a month to month and a half. Application usually requires submittal of a standard form and plans for the proposed project. 


\section{Zoning Certificate}

A zoning certificate is issued to ensure that a project to be constructed is allowed in the particular zone. A building permit will be required. If the zoning is proper for the proposed use, the certificate can often be issued immediately by the staff. Information required usually pertains to the proposed location and use.

\section{Variance}

Within each zone, standards are established regarding the location of structures on the lot. If, for some reason involving unusual lot conditions, compliance with the standards is impractical, a variance may be granted. Application usually requires a map showing the subject lot, its unusual conditions, and surrounding lots. A Board of Appeals may hold the public hearing to consider the application and approve or deny the request. If a Board of Appeals does not exist, the procedure is usually similar to that for a rezoning, with the Planning Commission recommending to the elected body who must approve or deny the variance. Minimum time for processing is about a month, though it will depend on the process of the particular jurisdiction.

\section{Floodplain Development Permit}

Where a project is proposed to be built near a body of water, a floodplain permit is often required. The major issue is usually the effect of the project on flooding conditions and on other properties. Normal processing time is about 30 days. Application is made through submittal of topographic maps showing the location of the proposed development. Processing will vary greatly. Generally a public hearing; will be held by the Planning and Zoning Commission, who will decide whether to issue the permit.

\section{Design Review Approval}

This process examines the functional logic and aesthetic impacts of proposed development plans, and is much more often a requirement of larger city governments than a county. A design review commitise consisting of design professionals and lay public often conducts such reviews. Processing time may be as little as 2 weeks.

\section{Sign Permit}

A permit is often required for a sign to certify that it complies with adopted standards. Other permits required for larger or special types of signs are usually similar to Conditional Use Permits. Application for a sign permit is likely to require submittal of plans, including a scale drawing of the sign and a plan showing how and where it is to be located. Processing usually consists of staff review of the plans for cch formance with ordinance requirements and may take only several days. 


\section{Construction}

\section{Permit or Regulation: Plumbing/Electrical Permits}

Agency: Idaho Department of Labor and Industrial Services (IDLIS)

These permits are based on compliance of plumbing and electrical plans with adopted plumbing and electrical codes. In the case of counties, these permits are administered by the Idaho Department of Labor and Industrial Services (IDLIS). The permits are issued directly to the contractors, rather than to the owner/operator of the facility being constructed.

\section{Permit or Regulation: Approval of a Private Road}

\section{Agency: Local Planning and Zoning Department/Planning and Zoning Commission}

Zoning ordinances often require public approval of a private road to ensure that adequate access will be provided to all parcels served by it and to evaluate its impact on the public street network. A plan of the proposed road showing dimensions, improvements, adjacent parcels, and land ownership generally serves as application. Approval may occur at the staff level after review, or may be granted after review by the Planning and Zoning Commission.

Processing time will usually be a few days if approval can be made at the staff level, and may be several weeks if review by the Planning and Zoning Commission is required.

\section{Permit or Regulation: County Road Access}

\section{Agency: Local Public Works Department; Local Highway District}

Many counties require approval for a proposed driveway or private road that will access from a county road. To obtain approval, a drawing of the proposed driveway/road showing location of access and relation to intersections, hill, etc., will probably be required. Approval is generally by the staff and can be granted within 2 weeks of application submittal.

\section{Permit or Regulation: Approval of Public Road Plans Agency: Local Public Works Department}

Any street to be dedicated to the public for maintenance purposes must meet established standardw for public streets and be approved by the responsible authority for streets and roads. If accomplished as part of a subdivision, processing will be as specified for subdivisions. If being undertaken as improvement to an existing street, plans are submitted to the street authority for review and approval. Processing can often be accomplished within several weels. 
Permit or Regulation: Right-of-Way Encroachment Agency: Local Public Works Department

Any work to be carried out within a putlic right-of-wdy requires a permit to interfere with the right-of-way. An application must state why such encroachment is necessary and the duration. In some cases, formal permits are not issued, but notification of the road authority with jurisdiction is necessary. Staff approval should be granted within several weeks.

\section{Permit or Regulation: Utility Agency: Local Public Works Department}

Installation of utility lines in a public right-of-way requires a utility permit. Plans must be submitted for staff review and approval. Processing may be accomplished within several weeks.

\section{Permit or Regulation: Building Permit/Occupancy} Agency: Local Building Department

The issuance of a building permit is based on the compliance of proposed plans with the adopted building code. In some counties, the building permit may be administered by the Idaho Department of Labor and Industrial Services. The occupancy permit allows utilities to provide permanent service to the use. It is issued after on-site inspection confirms that construction has been carried out in conformance with plans. Notice of construction completion must be given to trigger the inspection.

Timing for issuance of a occupancy permit will vary greatly depending on staff schedules, but can reasonably be expected to occur within 1 or 2 weeks of notification. Timing for issuance of a building permit for an industrial use can be expected to be at least several weeks after submittal of building plans.

\section{Safety and Health}

\section{Permit or Regulation: Discharge to the Public Sewer System Agency: Local Public Works Department}

In order to discharge project effluent into a public sewer system, a permit is required by most municipalities/sewer districts. Information about the character and amount of effluent and times of discharge must be supplied in the application. While evaluation and approval will normally occur at the staff level, the matter may be presented to the elected body prior to issuance of a permit for its concurrence. Timing on the permit may be several weeks to a month. 


\section{Permit Summary Sheet MONTANA}

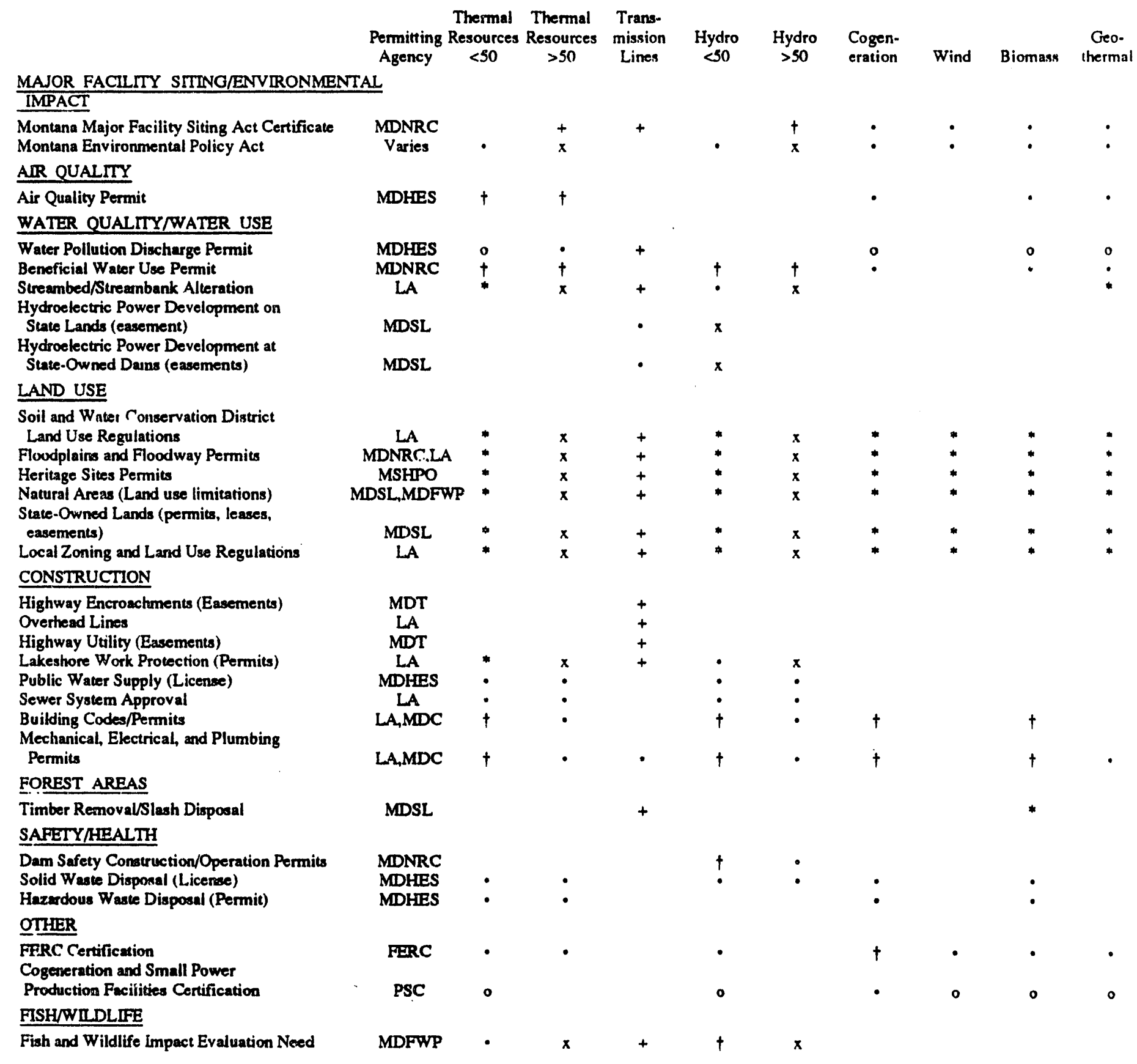

\section{Agencles Key}

Varies Lead agency varies by project

LA Local agencies

MDNRC Montane Dept. of Natural Resources and Conservation

MDHES Montana Dept. of Health and Environmental Sciences

MDSL Montana: Department of State Lands

MSHPO Montana State Historic Preservation Office

MDT Montuna Department of Transportation

MDC Montane Department of Commerce

MDFWP Montana Department of Fish. Wildlife, and Parks $t=$ Permit required

- Pernit may be required

x = Included in Montana Major Facility Siting Act review. The Siting Act supersedes other stave and local permitting requirementw not related to air and water quality or occupational safety, but applicants are strongly urged to work with local agencies to make sure their concernz are mot.

- = Site specific

+ - Trensmission lines greater than $115 \mathrm{kV}$ are covered by the Major Facility Siting AcL For these lines the Siting Act overrides other related to air and waver quality or occupational permits not safety. Transmission lines greater than $69 \mathrm{kV}$ but not greater than $115 \mathrm{kV}$ are exempt from the Act if they meet certain landowner approval requirements. Transmission lines $69 \mathrm{kV}$ or smaller are not covered by the Act. Lines of $230 \mathrm{kV}$ or less and 10 miles or less in length are also exempt from the AcL. 


\section{Chapter 3 The Montana State Process}

In Montana a hydropower developer will at least have to obtain a water right permit from the Department of Natural Resources and Conservation (DNRC), a "310" permit from the local permitting agency, and the relevant water quality permit from the Montana Department of Health and Environmental Science (MDHES).

Other state agencies that may require permits or otherwise act in a review capacity include: Montana Department of Health and Environmental Sciences; Department of State Lands; Department of Fish, Wildlife, and Parks; and the Engineering Bureau of the DNRC. Requirements of each agency are summarized below.

\section{Montana State Agencies' Responsibilities}

Agency: Montana Department of Natural Resources and Conservation (MDNRC); Board of Natural Resources (BNR); Board of Oil and Gas Conservation (BOGC) Statutory Authority: 2-15-3301 MCA

The Montana Department of Natural Resources and Conservation (MDNRC) executes statutory responsibilities concerning the state's land, water, and energy resources. MDNRC administers a wide range of state and federal programs dealing with renewable energy and energy conservation. It is also responsible for preparing environmental impact statements for projects that fall under Montana's Major Facility Siting Act and projects for which MDNRC is designated the lead agency under the Montana Environmental Policy Act. MDNRC has a broad array of responsibilities associated with the uses, development, and protection of Montana's water. The Board of Natural Resources and Conservation has authority to approve reservations of water under the Montana Water Use Act and to approve the siting of energy facilities under the Major Facility Siting Act.

\section{Agency: Montana Department of Health and Environmental Sciences (MDHES) Statutory Authority: 2-15-2101 MCA}

The Montana Department of Health and Environmental Sciences (MDHES) is responsible for administering the Montana Clean Air Act and implementing clean air programs and plans mandated by the federal Clean Air Act. Any proposed project that has the potential to emit more than 25 tons per year of any pollutant must obtain an air quality permit before construction. MDHES also administers the Montana Water Quality Act and the Montana Pollutant Discharge Elimination Permit Program. The MPDES permit contains water quality limitations and requires self-monitoring of effluent by the permittee. 
Agency: Montana Department of Fish, Wildlife, and Parks (MDFWP)

Statutory Authority: 2-15-3401 MCA

The Montana Department of Fish, Wildlife, and Parks (MDFWP) is responsible for managing Montana's wildlife, state recreation lands, and state parks. MDFWP policy is set by the Montana Fish and Game Commission. MDFWP also participates in the state's review of proposed new hydroelectric projects and controls many types of land in Montana. Its authority over these lands exists under a number of arrangements including patent, deed, lease, easement, agreement, or withdrawal. MDFWP participates with other state and local agencies to obtain instream water reservations for fish and wildlife, and to review and permit projects under the Stream Preservation Act. MDFWP reports to other state agencies on the impacts of major energy or other types of facilities on fish and wildlife resources.

\section{Agency: Montana State Historic Preservation Office (MSHPO) Statutory Authority: 2-15-1512 MCA}

The Montana State Historic Preservation Office (MSHPO) is responsible for cooperating with and advising other state agencies when potentially valuable historical, archaeological, or other cultural resources are located in a project area (Montana Antiquities Act and the National Historical Preservation Act). Part of the advice given to other agencies may include comments on an applicant's plan for impact mitigation of sites eligible for nomination to the National Register of Historic Places. MSHPO is also responsible for issuing antiquities permits for projects on state lands.

\section{Agency: Montana Public Service Commission (MPSC)}

Statutory Authority: 69-1-102 MCA

Montana's Public Utilities Regulation Law (69-3-101, MCA) defines a public utility as:

...every corporation, both public and private, company, individual, association of individuals..., that now or hereafter may own, operate, or control any plant or equipment, within the state, for the production, delivery, or furnishing for as to other persons, firms, associations, or corporations, private or municipal, heat,...power in any form or by any agency, water for business, manufacturing, household use...whether within the limits of municipalities, towns, or villages, or elsewhere...(Perlmutter, 1978).

The Montana Public Service Commission (MPSC) is a five-member elected body with the responsibility to ensure that public utilities provide adequate service to customers at reasonable rates. The MPSC's jurisdiction generally includes private, investor-owned natural gas, electric, telephone, and water companies doing business in Montana. In addition, the MPSC regulates intrastate railroads and certain motor carriers. The MPSC oversees natural gas pipeline safety regulations and has limited authority over municipal utilities's rate increases. The MPSC must approve utility rates, including those for Qualifying Facilities (QF). 
Agency: Montana Department of Transportation (MDT)

Statutory Authority: 2-15-2501 MCA

The Montana Department of Transportation (MDT) is responsible for all modes of transportation. The Highway Division constructs, maintains, and protects the state highway and bridge system. It also grants right-of-way easements for utilities and property access. In addition, it manages the state motor pool and the roadside rest areas, and enforces the state Outdoor Advertising Control Act. The Aeronautics Division enforces aeronautics safety rules and cooperates with federal authorities on civil aviation matters; it also manages state-owned airports and navigational beacons. The Rail and Transit Division is responsible for public transportation coordination and rate analysis and litigation. The Motor Transport Services Division enforces commercial vehicle weight and dimension laws, licensing, permitting, and fee collection on motor transport fuel taxes.

\section{Agency: Montana Department of State Lands (MDSL)}

Statutory Authority: 2-15-3201, MCA

The Montana Department of State Lands (MDSL) has four basic functions: management of the lands held by the state of Montana in trust for the support of the common schools and other institutions; regulation of mining conducted on private, state, and federal lands; fire prevention and suppression on certain private, state, and federal lands; and regulation of and assistance to private forest land owners. The state now holds approximately 5.2 million acres of surface and 6.2 million acres of mineral land, primarily for the common schools. In managing this land, the Department must obtain the highest long-term monetary return.

\section{Agency: Montana Department of Labor and Industry (ML\&I) Statutory Authority: 2-15-1701, MCA}

The Montana Department of Labor and Industry (ML\&I) serves as an employment agency, collects and disburses state unemployment funds, provides training, and oversees federal Job Training Partnership Act (JTPA) grants. The Department also enforces state wage and hour laws, provides for apprenticeships, administers the state's industrial safety laws, holds contractor bonds, hears disputes on state employee relations, unemployment insurance, and Workers' Compensation, enforces state and federal antidiscrimination in employment laws, and assists the public in the interpretation of the Worker's Compensation and Occupational Disease Acts. 


\title{
State Permitting and Licensing Requirements
}

\author{
Permit or Regulation: Certificate of Public Need and Environmental Compatibility \\ Statutory Authority: Major Facility Siting Act, 75-20-101 et seq., MCA \\ Agency: Board of Natural Resources and Conservation (BNRC)
}

The Montana Major Facility Siting Act provides for comprehensive review of proposals to construct and operate certain kinds of facilities for generating, converting, or transmitting energy in Montana. To minimize the impacts of such facilities, the Board of Natural Resources and Conservation (BNRC) must certify public need for and environmental compatibility of such facilities before construction begins.

The Act applies to the following types of generation, conversion, and transmission facilities.

1. Facilities that can generate $50 \mathrm{MW}$ or more of electricity;

2. Facilities that can use, refine, or convert 500,000 tons of coal or more per year;

3. Electric transmission lines and associated facilities of more than 69 kilovolts $(\mathrm{kV})$, except

a. Lines rated at $230 \mathrm{kV}$ or less and 10 miles or less in length;

b. Lines of more than $69 \mathrm{kV}$ and less than $116 \mathrm{kV}$ when the person planning to construct the line has obtained right-of-way agreements or options for a right-of-way from more than 75 percent of the owners who collectively own more than 75 percent of the property along the centerline;

4. Facilities for developing and using geothermal resources capable of producing 25 million Btu per hour or more.

Associated facilities such as transportation links, aqueducts, diversion dams, transmission substations, and other facilities associated with the production or delivery or energy are included. Federally-owned or controlled facilities located on federal lands must satisfy the substantive criteria of the Siting Act.

Certification is also required from the Department of Health and Environmental Sciences (MDHES) to ensure that the facility will not violate air and water quality standards or other laws administered by MDHES. Both MDNRC and MDHES must accept an application as complete before the evaluation process can begin. Application must be made on forms supplied by the departments.

Application for facilities filed under the Act must include a description of the proposed facility, with discussion of alternative sites; an explanation of need for a utility facility; and a filing fee, based on the estimated construction cost of the facility, to finance the state's evaluation. 
MDNRC and MDHES may not accept an application unless the facility is identified in a longrange plan submitted to MDNRC at least 2 years before the application is filed.

Submission of an application to MDNRC and MDHES starts a 90-day period in which the agencies must notify the applicant of any deficiencies. An acceptable application results in a study and evaluation by both departments. MDHES has 1 year for study and the MDHES or Board of Health and Environmental Sciences (BHES) have an additional 6 months to decide if air and water quality permits should be issued.

MDNRC has 22 months from the date it accepts the application to complete its study and prepare a report including recommendations to the Board of Natural Resources. The time limit for MDNRC's review and report for transmission lines under 30 miles long is 1 year.

BNRC must schedule a hearing within 120 days of receiving the department's report. The applicant, the departments, affected municipalities, residents, and interested individuals and organizations may participate. The entire hearing process, from the date of the department's report to the Board until the hearing examiner's report is filed, may not exceed 9 months unless the Board extends the time for good cause. The Board must make its decision within 60 days after the hearing examiner's report is submitted.

A certificate may not be granted unless the Board finds and determines: 1) the basis of the need for the facility; 2) the nature of the probable environmental impacts; 3) that the facility represents the minimum adverse environmental impact, considering the state of available technology and the economics of various alternatives; 4 ) that the facility is consistent with regional plans for expanding utility grids and will serve system economy and reliability; 5) that the facility's pro- . posed location conforms to state and local laws and regulations; 6 ) that the Board of Health has certified that the facility will not violate air and water quality standards and implementation plans; and 7) for a utility application, that the facility serves the public interest, convenience, and necessity. Need, environmental impacts, benefits to the applicant and the state, effects of resulting economic activity, and effects on public health, safety, and welfare must be considered in making these determinations.

After a certificate has been issued, BNRC, MDNRC, BHES, and MDHES all have ongoing responsibility to monitor certified facilities for compliance with certificate conditions and with air and water quality permits. Certificates may be revoked for failure to meet safety standards or failure to comply with any other conditions imposed by BNRC.

An important element of the Siting Act is its general applicability over other state laws. This authority means that if BNRC issues a certificate, no other state or local permit for construction or operation is required, except for air and water quality permits. In addition, such laws protecting employees are not superseded by the Siting Act. 
Permit or Regulation: Permits, Licenses, Approvals

Statutory Authority: Montana Environmental Policy Act, 75-1-101 et seq., MCA

Agency: Varies by Project

Before any major action significantly affecting the quality of the environment is taken, a state agency must prepare an environmental impact statement (EIS) discussing the environmental inpacts of the proposed action. The EIS requirement applies to issuance of state permits, licenses. and approvals for privare actions that will have significant environmental impacts. When a single project requires permits from two or more agencies, a lead agency will be designated to collect the EIS fee and to coordinate preparation of the document.

Copies of the EIS and the comments and views of the appropriate state, federal, and local agencies authorized to develop and enforce environmental standards must be made available to the Governor, the Environmental Quality Council, and the public, and must accompany the proposal through the existing agency review processes. Alternatives to the proposal, irretrievable commitments of resources, and the relationship between short-term uses of the environment and longterm productivity must be discussed in the EIS.

An agency may prepare a preliminary environmental review (PER) to determine whether an EIS is necessary. If the need for an EIS is clear, the PER step may be bypassed. If the PER indicates no potential significant environmental impact, an EIS need not be prepared and the agency may proceed with the proposed action.

If an EIS is necessary, the agency must prepare a draft EIS that is circulated to other agencies and to the public for comment. At least 30 days are allowed for comment with the possibility of a 30 day extension. A public hearing may be held after publication of the draft EIS. The agency is required to hold a hearing if a certain level of citizen interest is demonstrated.

A final EIS will be prepared if necessary, incorporating responses to comments on the draft and comments received at the hearing if one was held. Final action on a permit may not be taken sooner than $\mathbf{4 5}$ days after publication of the draft EIS nor sooner than 15 days after publication of the final EIS.

\section{Water Quality/Water Use}

\section{Permit or Regulation: Beneficial Water Use Permit}

Statutory Authority: Montana Water Use Act, 85-2-101 et seq., MCA

Agency: Montana Departm ent of Natural Resources and Conservation (MDNRC)

Water Right Permit A water right permit to use water for a hydro project is necessary in all cases where surface water meaning streams, rivers, lakes, natural ponds, undeveloped springs, etc., will be used or if a groundwater source meaning wells, pits, developed springs, etc., with a maximum appropriation of 100 gallons per minute of water or more will be used. However, if the hydropower project is located outside the boundary of a controlled groundwater area, a per- 
mit is not required before appropriating groundwater by means of a well or developed spring with a maximum appropriation of less than 100 gallons per minute. A Notice of Completion of Groundwater Development Form No. 602-must be filed, however, to obtain a water right.

The Montana Water Use Act 85-2-101 et seq., MCA, requires a permit for appropriation for any use of water over $0.38 \mathrm{~m}^{3}$ (100 gallons) per minute. A permit must be issued if the applicant proves by substantial credible evidence that:

1. Unappropriated water in the supply source at the point of diversion is available, in the amount and during the period required by the applicant.

2. The rights of prior appropriators will not be adversely affected.

3. The proposed ineans of diversion, construction, and operation of the appropriation works are adequate.

4. The proposed use of the water is a "beneficial use." Beneficial uses include, but are not limited to, agriculture, domestic use, fish and wildlife, mining, industrial activity, municipal supply, power generation, and recreation.

5. The proposed use will not interfere unreasonably with other planned uses or developments for which a permit has been issued or for which water has been reserved.

6. The applicant has a possessory interest or written consent to use the property where the water is put to beneficial use.

If the small hydro developer has an existing water right, the law also provides for changes of that right as it relates to changing the place of diversion, place of use, purpose of use, or place of storage.

Application for Beneficial Water Use Permits (Form No. 600), Notices of Completion of Ground Water Development (Form No. 602), and Applications for Change of Appropriation Water Right (Form Ne 606) may be obtained from the Water Resources Division, Montana Department of Natural Resources and Conservation, 1520 E Avenue, Helena, MT 59620, at the local county clerk and recorder's offices, or from any of the Water Rights Bureau offices located in Bozeman, Helena, Missoula, Kalispell, Havre, Glasgow, Lewistown, Miles City, or Billings. It is recommended that at least six months be allowed to process the permit or change of application request. 
Permit or Regulation: 310

Statutory Authority: Natural Streambed and Land Preservation Act, 7-5, 7-101, et seq., MCA Agency: Conservation Districts (MDNRC)

In applying for a 310 permit, the applicant must comply with the provisions set forth in the Natural Stream Bed and Land Preservation Act, which came into existence during the 1975 Legislative Session with the passage of Senate Bill 310. The purpose of this act is to protect and preserve the natural perennial-flowing rivers and streams, the land and property immediately adjacent to them, to prohibit unauthorized projects, and to protect the use of water for any useful or beneficial purpose as guaranteed by the constitution of the state of Montana. The Act applies to all private individuals and corporations on private, state, or federal land.

Any physical alteration of a natural perennial flowing stream, its beds, or immediate banks requires approval from either the Soil and Water Conservation District Supervisors, the Grass Conservation District Supervisors, or the Board of County Commissioners. In addition, a permit is required from the Army Corps of Engineers for any dredge and fill activity or other work affecting "navigable waters." This may include dredge or fill activity in wetlands.

Before engaging in any project that may obstruct or alter a stream, a state or local government agency must notify the Montana Department of Fish, Wildlife, and Parks (MDFWP). The MDFWP must notify the applicant whether the project will adversely affect fish or wildlife habitat. The MDFWP may require modifications to the project. If agreement cannot be reached, an arbitration panel may be appointed by the district court.

\section{Permit or Regulation: Montana Pollution Dischäge Elimination System Permit Montana Groundwater Pollution Control System Permit} Statutory Authority: Montana Water Quality Act, 75-5-101 et seq., MCA Agency: Montana Department of Health and Environmental Sciences (MDHES)

A permit from the Montana Department of Health and Environmental Sciences (MDHES) is required to construct, modify, or operate a disposal system or to construct or use any outlet for discharge of sewage, industrial, or other wastes into state surface or groundwaters.

MDHES may authorize short-term exemptions from certain water quality standards for necessary construction, or hydraulic projects that may have short-term water quality impacts.

The applicant for a water pollution discharge permit must file an application for a Montana Pollution Discharge Elimination System (MPDES) permit or a Montana Groundwater Pollution Control System (MGWPCS) permit no less than 180 days prior to the operation of a point source. The discharge of pollutants into state waters in excess of the MPDES permit's restrictions constitutes violation of the permit. 
If effluent limitations or other conditions are imposed on a discharge permit in order to maintain water quality at levels better than the applicable water quality standards as directed by the state's non-degradation policy, the permittee may petition the Board of Health for an exemption from such non-degradation requirements.

\section{Fish and Wildlife}

\section{Review Authority - Montana Department of Fish, Wildlife, and Parks (MDFWP)}

Although the Montana Department of Fish, Wildlife, and Parks (MDFWP) does not have permitting authority per se they are entrusted with extensive review authority and thus play a major role in determining eligibility to receive other necessary permits including the FERC license. The MDFWP is concerned with environmental impacts of proposed projects including adverse effects on fish, wildlife, and recreation in the evaluation of any particular site. The MDFWP is concemed with the following specific items:

1. Flow fluctuations on a daily basis or modification of existing flow regime on a seasonal basis;

2. Alterations in water temperature or other water quality parameters resulting from location or means of water withdrawal/discharge;

3. Impacts associated with possible increased reservoir operating level or increase in extent of winter drawdown;

4. Impacts associated with power line siting, construction, and operation;

5. Impacts to the riparian habitat, streambank, and/or streambed associated with power plant construction and operation;

6. Potential for streambank erosion downstream;

7. Frequency and extent of furure repair or maintenance.

It is strongly recommended that contact be made with the Montana Department of Fish, Wildlife, and Parks (MDFWP) early in the preliminary design phase of project development in order to eliminate possible problems early in the process. 


\section{Land Use}

Permit or Regulation: Soil and Water Conservation District Land Use (Regulations) Statutory Authority: 76-15-701 et seq., $M C A$

Agency: Local Soil and Water Conservation Districts

Lands located within a soil and water conservation district may be subject to land use regulations designed to conserve soil and water resources and control erosion. Variances are awarded upon demonstration of great practical difficulties or unnecessary hardship. Types of activities regulated may include engineering operations for dams, dikes, ponds, ditches, fences, and other construction.

\section{Permit or Regulation: Floodplain and Floodways Permit} Statutory Authority: Floodplain and Floodway Management Act, 76-5-101 et seq., MCA Agency: Montana Department of Natural Resources and Conservation (MDNRC)

Artificial obstructions and nonconforming uses within a designated floodplain or floodway require a permit from the local governing body, or from the Montana Department of Natural Resources and Conservation if local authorities have not adopted rules. Local governments may adopt land use regulations, including floodplain management regulations within sheetflood areas, that may restrict development. If local regulations are not adopted, MDNRC must enforce minimum standards adopted by the Board of Natural Resources and Conservation.

Usually the permit application is acted upon within 60 days after receipt unless additional information is necessary or an environmental impact statement is required.

Permit or Regulation: Heritage Site (Permit or License)

Statutory Authority: Montana Antiquities Act, 22-3-421 through 442, MCA

Agency: Montana State Historic Preservation Office (MSHPO); Land Management Agencies

State actions or state licenses, assisted, or permitted actions that have the potential to substantially alter heritage properties or paleontological remains on state-owned lands are regulated, as is excavation of heritage properties on state-owned lands.

In consultation with the MSHPO, the land management agency is required to determine whether a proposed action may impact sites, structures, or objects on state-owned lands that qualify or would qualify as heritage properties. This may require completion of a systematic cultural resources inventory, recordation of a property likely to be harmed, consideration of altemative projects, special protective stipulations, and project modifications, or clenial of the project. Agencies may require applicants for permits or licenses to complete portions of this analysis. 
Permit or Regulation: Natural Areas (Land Use Limitations)

Statutory Authority: 76-12-101 et seq., MCA

Agency: Board of Land Commissioners (BLC)

A natural area is one affected primarily by natural forces, with evidence of human activity at a minimum, and with outstanding natural features worthy of preservation. State-owned lands that are controlled or acquired by the BLC may be designated natural areas. Each area so designated is managed by a "managing entity" and will be subject to a master plan setting forth specific land use limitations and controls. If feasible, the state of Montana will hold the water and mineral rights in order to adequately protect the area.

Permit or Regulation: State-Owned Lands (Permits, Leases, Easements) Statutory Authority: Title 77, Chapters 1-6, MCA Agency: Montana Department of State Lands (MDSL), Montana Department of Fish, Wildlife and Parks (MDFWP), Montana Department of Natural Resources and Conservation (MDNRC), and Other State Agencies

Activities on state-owned lands generally require permits, leases, or easements from the Montana Department of State Lands and approval from the Board of Land Commissioners. In addition, the MDFWP, MDNRC, and other state agencies should be contacted for information regarding rules and procedures on lands owned or administered by those agencies.

Permit or Regulation: Easement on State School Trust Land Statutory Authority: Title 77, Chapter 2, MCA Agency: Board of Land Commissioners or Montana Department of State Lands (MDSL)

The Montana Department of State Lands (MDSL) is involved in the permitting process for development if the proposed project is on state school trust land. The applicant is required to obtain an easement from the MDSL. Two types of easements are available:

"Permanent Easements" require the approval of the Board of Land Commissioners, with applications requiring about 2 or 3 months for approval.

"Temporary construction permits" along or adjacent to permanent easements may be granted by license agreement with the MDSL. The MDSL is required to obtain full market value for all easements on state lands. Thus, market value would need to be determined and sought. 


\section{Construction}

Permit or Regulation: Highway Encroachments (Easements)

Statutory Authority: 7-14-2139, MCA

Agency: Lepartment of Highways (DH)

Permits are issued by the DH for construction or maintenance of encroachments on or under highway rights-of-way. Encroachments include all private structures, devices, and facilities placed upon, over, or under the right-of-way. These include ditches, dikes, flumes, canals, or bridges and water, sewer, electric, natural gas, and communications lines. Written permission is requircd from the Board of County Commissioners for any excavation or construction across county highways. Permission for easements and encroachments on or across state highway rights-of-way may be obtained from the Department of Highways.

Permit or Regulation: Highway Utilities (Easements)

Statutory Authority: 7-13-2101, 4101, MCA

Agency: Department of Highways (DH)

Utility facilities used to transport or distribute hydrocarbons, electric power, energy communication signals, water, and sewage are authorized to occupy highway rights-of-way if they conform to certain standards as approved by the $\mathrm{DH}$. City councils and boards of county commissioners grant similar approval along city streets and county roads.

\section{Permit or Regulation: Public Water Supply (License)}

Statutory Authority: 75-6-101 et seq., MCA Agency: Montana Department of Health and Environmental Sciences (MDHES)

A water system serving 10 or more families or 25 or more persons for 60 days out of the calendar year must be approved by the Montana Department of Health and Environmental Sciences (MDHES). Plans and specifications for public water supply wells must be approved, as well as plans for construction, alteration, or extensions of any water system or treatment facilities. Operators in charge of public water systems and treatment facilities must be licensed by MDHES.

\section{Permit or Regulation: Sewer System (Approval)}

Statutory Authority: 75-6-101 et seq., MCA

Agency: Water Quality Bureau, Montana Department of Health and Environmental Sciences (MDHES)

Approval from the Water Quality Bureau, Montana Department of Health and Environmental Sciences (MDHES), is required to construct, alter, or extend a public sewer system serving 10 or more families or 25 or more persons for at least 60 days out of the calendar year. Operators in charge of public sewer systems must be licensed by MDHES. 
Permit or Regulation: Building Codes (Permit)

Statutory Authority: 50-60-101 et seq., $M C A$

Agency: Building Codes Bureau, Montana Department of Commerce (MDC)

All construction throughout the state must comply with the state building codes and permit regulations. If towns or counties adopt local building codes, enforcement is by local rather than state authorities. A permit must be obtained from appropriate authorities before construction can begin.

Permit or Regulation: Mechanical, Electrical, and Plumbing (Permits)

Statutory Authority: 50-60-101 et seq. (Mechanical)

50-60-602 et seq. (Electrical)

50-60-501 et seq. (Plumbing)

Agency: Building Codes Bureau, Department of Commerce

A mechanical permit is required for the design, construction, installation, quality of materials, location, operation, and maintenance of heating, ventilating, cooling, or refrigeration systems; incinerators; and other miscellaneous heat producing appliances.

An electrical permit is required for any electrical installation in any new construction or remodeling.

A plumbing permit is required for the installation, removal, alteration, or repair of plumbing and drainage systems or parts thereof.

The local building department may administer an enforcement program in lieu of the state program.

\section{Miscellaneous Permits}

Permit or Regulation: Slash Disposal/Timber Cutting (Permit)

Statutory Authority: 76-13-401 through 413, MCA

Agency: Montana Department of State Lands (MDSL)

A permit is required from the Montana Department of State Lands (MDSL), Forestry Division, for slash disposal, timber cutting, or timber stand improvements on private lands or right-of-way clearing by public or private utilities. 
Permit or Regulation: Dam Safety Construction/Operation Permit Statutory Authority: Montana Dam Safety Act, 85-15-101 et seq.; MCA Title 85, Chapier 2, Parts 3 and 4; MCA 77-4-201 through 210 Agency: Departmer. of Natural Resources and Conservation (MDNRC)

A dam owner must obtain a dam safety construction permit from the Department of Natural Resources and Conservation (MDNRC) prior to constructing any new high-hazard dam or reservoir that impounds at least 50 acre-feet, enlarges or removes an existing high-hazard dam or reservoir impounding at least 50 acre-feet, or extensively repairs or alters an existing high-hazard dam or reservoir impounding 50 acre-feet or more. In addition, a dam safety operation permit needs to be obtained before operating both and existing new high-hazard dams

If the proposed dam facility would be on a stream located on state-owned lands, a lease or a license must be obtained from the Board of Land Commissioners.

\section{Permit or Regulation: Solid Waste Disposal (License)}

Statutory Authority: Solid Waste Management Act, 75-10-201 et seq., MCA Agency: Department of Health and Environmental Sciences (MDHES)

A license is required from the MDHES for disposal of solid waste and for the operation of a solid waste disposal facility. Sites are approved and licensed by MDHES and validated by local health officials. A preliminary environmental review (PER) is a necessary part of the solid waste application review process. Any person may apply to the Board of Health and Environmental Sciences for a variance from the rules.

\section{Permit or Regulation: QF Certification}

Statutory Authority: Cogeneration and Small Power Production Facilities, 69-3-601, MCA Agency: Federal Energy Regulatory Commission (FERC) and Montana Public Service Commission (MPSC)

A cogeneration or hydropower production facility may be certified as a qualifying facility (QF). To be a QF, a facility must meet certain requirements as stated in Montana law: 1) produce electricity by the use, as a primary energy source, of biomass, waste, water, wind, or other renewable resource or any combination of those sources; or 2) produce electricity and useful forms of thermal energy, such as heat or steam, used for industrial, commercial, heating, or cooling purposes through the sequential use of energy known as cogeneration; 3) have a power production capacity that together with any other facilities located at the same site is not greater than $80 \mathrm{MW}$; and 4 ) be owned by a person not primarily engaged in the generation or sale of electricity other than electric power from a small power production facility.

FERC controls the certification process for a $\mathrm{QF}$. Facilities that are connecting to a utility can get interface guidelines from that utility. The Montana Public Service Commission (MPSC) determines rates and conditions of those rates for contracts between small power producers and the utilities under MPSC's jurisdiction. 


\section{Permit or Regulation: Proposed Rules for Integrated Least Cost Planning Agency: Montana Public Service Commission (MPSC)}

The goal of integrated least cost resource planning is to enable electric utilities to provide energy services and products in a manner consistent with the interests of their customers and the general public while remaining financially viable. To achieve this goal utilities must actively pursue and acquire all cost-effective and practicable energy efficiency. It is the policy of the MPSC to promote integrated least cost planning for electric through the rules.

The draft rules are aimed at providing the utilities with policy and planning guidance. They are not intended to specify the outcome of the planning process. Each utility's plan, anticipated to consist of an integrated set of supply and demand options, will be the result of the utility's unique planning process and judgment.

Integrated least cost resource planning is an ongoing, dynamic, and flexible process which:

explicitly manages the consequences of uncertainty and risk associated with the utility's market characteristics and supply altematives;

integrates the demand and supply-side resources that represent the least cost to society over the long term;

explicitly weighs a broad range of resource attributes (e.g., environmental externalities) in the evaluation of altemative resources;

should be understandable to interested persons (including members of the general public) and the MPSC;

involves stake holders and non-utility expertise in utility planning; and

results from a planning process within the utility which facilitates communication and coordination among the entities dealing with demand forecasts and demand and supply-side resource evaluations.

\section{Competitive Resource Acquisition and Integrated Least Cost Planning}

Competitive bidding is important to the overall least cost planning process in general, and efficient resource acquisition in particular. Competitive bidding provides utilities valuable information on available demand and supply-side resource acquisitions. Electric utilities shall use the following guidelines:

Incorporate competitive resource acquisition into their overall integrated least cost planning processes. Competitive bidding, however, must not be seen as a substitute to least cost planning.

Resources submitted in response to the utility's request for bids must be evaluated consistently with the goals and definition of integrated least cost planning. 
Resource solicitations shall be issued to the broadest practical group of potential demand and supply-side resource providers, including but limited to: PURPA qualifying facilities (QFs); non-utility independent power producers; publicly and investor-owned utilities; power marketing agencies; international suppliers; and organizarions capable of providing demand-side resources.

Demand-side competitive acquisition programs shall be seen as a complement of utility demand-side programs, not a substitute for them. Utility-directed programs shall be aimed at specific sectors where market barriers or other market failures prevent that demand-side resources from being effectively and efficiently developed.

The competitive acquisition process for demand-side resources shall not allow the acquisition of high retum demand-side resources if such acquisition means that other measures, which would be cost effective only if they were acquired in conjunction with those high retum resources, are not acquired; this same protection shall be applied to utility demand-side acquisition programs.

\section{Local Permitting and Licensing Requirements}

Within the framework of federal and state regulation, local governments perform duties which can have unique and significant impacts on energy project development. Local governments can set an example by financing and developing energy facilities themselves. They can encourage private development through information distribution and active recruiting of facilities. Cities and counties also regulate energy facilities. Below state-level citing thresholds, the jurisdictions are the primary development permitting authority. They set land use policy which controls the type and location of future development and affect construction techniques by enforcing building and electrical codes. They direct the division of lots through subdivision ordinances. They also regulate the type, mix, and location of land uses using zoning ordinances.

Zoning ordinances implement policies established in local land use plans and reduce land use conflicts by dictating: 1) the type of development allowed within the jurisdiction; 2) the design of those uses; and 3) the way potentially conflicting uses may coexist.

Policies and standards reflect both technical information and popular opinion. Local land use law often reflects values that are difficult to evaluate objectively. Public participation in a project approval may reveal concerns for property values, neighborhood quality, and scenic quality. These subjective values are difficult to put into laws. Few local governments have done more with energy facility regulation than provide a forum for public involvement in siting decisions.

Counties and incorporated cities prepare and adopt comprehensive land use plans which are acknowledged by a state-level commission. The plans indicate the location and significance of af- 
fected resources and provide a regulatory framework for potentially using them. If a conflict is identified which is resolved against energy resource development, then another site must be found, unless the plan is amended. If the conflict is resolved in favor of energy resource development then, from a land use perspective, resource use is feasible. Development still may be subject to conditions which mitigate negative impacts. These requirements are described in the plan and local ordinances. Thus, developers can use comprehensive plans to learn what kind of projects might be feasible, and under what conditions.

Some counties discuss renewable resources in their comprehensive plans. However, discussion in the plans has often not led to zoning and ordinances. Frequently, adequate and up-to-date data on resources' location, quantity, and quality has not been given to local governments. Also, energy issues are not a priority in land use planning circles or most local governments.

In the absence of attention to the energy resource in the local land use plan, a prospective developer may have to champion a project proposal through the entire land use planning, zoning, and ordinance-writing processes. Such an effort would add many months to a project's lead time and increase its cost. Along the way, design changes are likely or the project may be found infeasible. The local government and public would be involved in broad planning, policy-making, and ordinance issues in the context of community reaction to a proposed project.

Local govemments such as cities, counties, road districts, flood control districts, and drainage districts will have some jurisdiction over geothermal development in nearly all cases. Most county governments in Montana require building permits for construction and entail building code, electrical code, and plumbing code compliance. Most counties also have planning and zoning commissions that will review project plans for compliance with comprehensive plans, zoning regulations, and needs for conditional or special use permits. Counties may also have some jurisdiction over construction in or near defined flood plains and over use of, or construction near, county highways. The county courthouse, the county zoning administrator, and the county highway district are the best contacts for determining what permits or approvals will be required.

If a proposed site is within a city's limits or within its area-of-impact, appropriate contact should be made with city officials regarding building permits, zoning regulations, flood plain construction, and highway usage. Contact the city hall of the nearest city for a determination of the required permits and approvals and jurisdiction.

Smaller communities often issue all permits through a single office, such as the Clerk. In some counties, one or more highway districts exist that are responsible for construction and maintenance of roads. These agencies will be the administrators of all permits/approvals having to do with public rights-of-way.

A number of these permits, mainly those administered by the Planning Department, will involve substantial discretionary action on the part of the decision makers, approval being based on con- 
formance of plans with established criteria or standards. Therefore, these decisions will usually be made by elected or appointed officials (city councilmen, county commissioners, or planning and zoning commissioners). Another group of approvals will be based on the adequacy of technical plans. These will generally be the permits listed as being administered by the public works department and building department. Several items will be simply a matter of registration, including the business license and registration of proprietorship. The following is a general description of each of the permits and approvals which may be required.

\section{Determining Which Permits are Required}

To enable a developer to determine what local permits are necessary for a particular site, and for guidiance in obtaining local permits, the following guidelines are provided.

- Determine with certainty within what local jurisdiction the project site lies. Assumptions about jurisdiction are often inaccurate. Even if a site is within the county, it is possible it may be within a city's Area of Impact, which would give the city certain jurisdiction over the project.

- Contact agency staff early to obtain information about permits and to discuss your plans. Go into their office in person to make personal contact and to show your commitment to expediting the permitting process.

- Determine what permits will be required for the proposed project; what information should be provided; the process that will be followed; and time frames, including submittal dates, hearing dates, and the time within which a decision can be expected.

- Get copies of the applicable regulations so you can personally review them and the evaluation criteria. Ask questions if the written regulations vary from information the staff has provided.

- In the case of more discretionary permits, ask the staff about the likelihood of approval; also what might help to speed up the process and decision.

- Submit a complete application. Incomplete applications will result in processing delays.

- Attend all meetings where the application will be discussed. If there is no one to respond to questions, delays may occur or the permit may be denied. 


\section{Land Use}

Permit or Regulation: Local Zoning and Land Use Regulations

Statutory Authority: Title 76, Chapter 2, MCA (Counties)

Title 76, Chapter 3, MCA (Municipalities)

Agency: Local Planning \& Zoning Department

Before commencing any development or activity a person should determine if local zoning regulations exist. Under Montana law, cities, towns, and counties may adopt zoning regulations and establish zoning districts for the regulation of height and size of buildings, percentage of lot occupied, size of yards, density of population, location, and use of buildings, etc. If zoning exists, a permit for the development or activity may be required.

Permit or Regulation: Soil and Water Conservation District Land Use Regulations Statutory Authority: 76-15-701 et seq., $M C A$

Agency: Local Soil and Water Conservation Districts

Lands located within a soil and water conservation district may be subject to land use regulations designed to conserve soil and water resources and control erosion. Variances awarded upon demonstration of great practical difficulties or unnecessary hardship are allowed.

Types of activities regulated may include engineering operations for dams, dikes, ponds, ditches, fences, and other construction.

\section{Construction}

Permit or Regulation: Highway Encroachments Easements Statutory Authority: 7-14-2139, MCA Agency: Board of County Commissioners (BCC) and/or Department of Transportation (MDT)

Written permission is required from the Board of County Commissioners (BCC) for any excavation or construction across county highways. Permission for easements and encroachments on or across state highway rights-of-way may be obtained from the Montana Department of Transportation (MDT).

Permit or Regulation: Overhead Lines

Statutory Authority: 69-4-401 et seq., 69-4-601, 602, 7-13-4106, MCA

Agency: Local Planning \& Zoning Department

The city or town council may regulate erection of poles and cables within city limits. Persons moving buildings, equipment, or other structures that will require moving overhead lines must give the person responsible for operating the lines 10 days notice. 
Permit or Regulation: Highway Utilities Easements

Statutory Authority: 7-13-2101, 4101, MCA

Agency: City Council, Board of County Commissioners (BCC), or

Department of Transportation (MDT)

Utility facilities used to transport or distribute hydrocarbons, electric power, energy communication signals, water, and sewage are authorized to occupy highway rights-of-way if they conform to certain standards as approved by the Montana Department of Transportation (MDT). City councils and boards of county commissioners grant similar approval along city streets and county roads.

\section{Permit or Regulation: Lakeshore Protection Permit}

Statutory Authority: 75-7-207 through 217, MCA

Agency: Relevant Local Agency

If the local government has adopted lakeshore protection regulations, a permit is required for any work that will alter the current or cross-sectional area of a navigable lake or its shore. Such activities include constructing channels or ditches; dredging the lake bottom to remove muck, silt, or weeds; ponding; filling; and constructing breakwaters or wharves and docks. A variance from local regulations may be obtained if an impact statement is prepared and a public hearing held.

The proposed work must not: 1) materially diminish water quality; 2) materially diminish habitat for fish or wildlife; 3 ) interfere with navigation or other lawful recreation; 4) create a public nuisance; or 5) create a visual impact discordant with natural scenic values as determined by the local government, where such values form the predominant landscape elements.

If petitioned by 30 percent of the landowners with property abutting a lake, the Montana Department of Natural Resources and Conservation (MDNRC) may adopt and enforce regulations.

\section{Permis or Regulation: Building Permit \\ Statutory Authority: 50-60-101 et seq., MCA \\ Agency: Local Building Department}

All construction throughout the state must comply with the state building codes and permit regulations. If towns or counties adopt local building codes, enforcement is by local rather than state authorities. A permit must be obtained from appropriate authorities before construction can begin. 
Permit or Regulation: Mechanical, Electrical, and Plumbing Permits

Statutory Authority: 50-60-101 et seq., MCA (Mechanical)

50-60-602 et seq., MCA (Electrical)

50-60-501 et seq., MCA (Plumbing)

Agency: Local Building Department

A mechanical permit is required for the design, construction, installation, quality of materials, location, operation, and maintenance of: heating, ventilating, cooling, or refrigeration systems; incinerators; and other miscellaneous heat producing appliances.

An electrical permit is required for any electrical installation in any new construction or remodeling.

A plumbing permit is required for the installation, removal, alteration, or repair of plumbing and drainage systems or parts thereof.

The local building department may administer an enforcement program in lieu of the state program. 


\section{Permit Summary Sheet OREGON}

\section{AIR QUALITY}

Energy Facility Siting Certificate Air Contaminant Discharge Permit Notice Constr/Approval of Plans

WATER QUALITY/WATER USE

Water Pollution Control Facility

Nah. Pollutant Discharge Elimination Sys.

Gon. Permit Water Pollution Discharge Sources

Water Rights Permit

Hydroolectric Permit

\section{LAND USE}

Local PlanVone Regulations

Land Use Compatibility Statement

State-Owned I, ands (permits, leases, easements)

Soil and Water Conservation District Land Use

$$
\text { Regulations }
$$

Streambed/Streambank Alteration

Floodplains and Floodway Permits

Heritage Sites Permits

\section{CONSTRUCTION}

Building Permits

Mechanical, Electrical, and Plumbing Permits

Highway Encroachments Easements

Overhead Lines

Highway Utility Easements

FISH/WILDLIFE

Fish \& Wildlife Impact Eval.

FOREST AREAS

Timber Removal/Siash Disposal Permit

SAFETY/HEALTH

Dam Safety Construction/Operation

$$
\text { Permits }
$$

Boiler License

\section{ENERGY FACILITY}

Energy Pacility Site Certificate

Qualifying Facility Certificate

SOLD HAZARDOUS WASTE

Solid Wave Disposal License

Hezardous Waste Disposal Permit

Thermal Thermal
Trans-
Permitting Resources Resources
Agency

OEFSC

ODEQ

ODEQ

ODEQ

ODEQ

ODEQ

OWRD

OWRD

LA

ODSL

$$
\text { LA }
$$

OSHPO

LA
LA
LA,ODOT
LA
LA,ODOT

ODFW

ODOF

OWRD

OBCA

ODOE

OPUC

ODEQLAA

ODEQ

\section{Agencie:}

LA

ODSL

OERSC

ODFW

ODOE

ODOF

ODEQ

ODOT

OPUC

OWRD

OSHPO

OBCA
Local Agencies

Oregon Division of State Lands

Oregon Energy Facility Siting Council

Oregon Department of Fish and Wildlife

Oregon Department of Energy

Oregon Department of Forestry

Onegon Department of Environmental Quality

Oregon Department of Transportation

Oregon Public Utility Commission

Oregon Water Resources Department

Oregon Stave Historic Preservation Office

Oregon Building Codes Agency
Key

$\dagger=$ Permit required

- - Permit may be required

$x=$ Included in Energy Facility Site Certificate review. The Siting Act supersedes other state and local permitting requirements, but applicants must get local agency approvals.

- - The agency provides comments on projects to other agencies processing permits.

+ - Tranamiasion lines greater than $230 \mathrm{kV}$, plus longet than 10 miles, plus are ficaled in more than 1 political subdivision must get a Site Certificate. Lines not meeting all three criteria. 


\section{Chapter 4 The Oregon State Process}

Anyone using water for hydroelectric power generation in Oregon must obtain a license or permit from the Oregon Water Resources Department (OWRD). A private developer may apply for a preliminary permit, that enables the applicant to make necessary examinations and surveys, and prepare maps, plans, specifications, and cost estimates of the proposed project in order to reserve a priority date for the project. The priority date is assigned on the date the application is filed and determines which project takes precedence over others applying for hydroelectric power projects on the same stream. However, priority dates may not apply if a consolidated review of all projects on a stream system is conducted. A consolidated review is conducted when the Water Resources Commission determines that the proposed project may have unacceptable cumulative impacts on natural resources. Cumulative impacts are effects by past, present, or pending hydroelectric projects, developments, or facilities in the same river basin.

\section{Standards for Siting Hydroelectric Projects}

Laws passed by the 1985 Legislature set strict standards for hydroelectric projects. The Water Resources Commission has adopted administrative rules further clarifying standards that must be met before a hydroelectric project can be constructed. A copy of the rules may be obtained from the OWRD.

As specified by Oregon statutes, no hydroelectric activity can result in mortality or injury to anadromous salmon and steelhead. The term "anadromous" means any species of salmon or any steelhead trout that spends a portion of its life in the ocean and returns to freshwater to spawn.

For a proposed new project on a stream with anadromous fish, the applicant must prove that the project can be operated without the possibility of causing injury or mortality to a single salmon or steelhead. However, it is the position of the Oregon Department of Fish and Wildlife (ODFW) that the technology does not presently exist to design such a project.

Modifications to existing facilities on streams with anadromous fish are allowed if the applicant can:

- Show that the design of the project will restore, enhance, or improve the existing anadromous salmon or steelhead habitat.

- Prevent a net loss of wild game fish or certain kinds of recreational activity.

- Prevent conversion of a wild game fish population and fishery to a hatchery-dependent resource. 
- Show that the design is consistent with ODFW fishery management plans and programs, and the Water Resources Commission hasin plans and programs.

- Employ workable and generally accepted methods and techniques best suited to the fish resources affected by the proposed project.

On streams without anadromous fish, development of hydroelectric facilities may be easier. However, even then the applicant must show that the proposed facility would not result in a net loss of wild game fish or certain kinds of recreational opportunities. No activity will be approved that results in a net loss of natural resources.

Applications will not be accepted for any project in designated resource areas such as national parks, national monuments, and wilderness areas. See Table 4 for a complete list of designated areas.

Projects in special management areas, such as national wildlife refuges, national recreation areas, state forests, and city parks, must follow the special management agency guidelines established for those areas. The Water Resources Commission will decide if the project follows those guidelines only after a review of recommendations from the appropriate special management agency. A complete list of special management areas is given in Table 5.

If other hydroelectric projects exist or are proposed in the same river basin, the Water Resources Commission will consult with the affected agencies to determine any cumulative impacts on natural resources. The combined effects of existing or pending hydroelectric projects, developments, and facilities in the same river basin will be reviewed. For a complete list of public and private agencies, refer to Table 6.

Cumulative impacts have been addressed in the Water Resources Commission's Basin Plans. The plans establish limitations in areas with inadequate water supplies for existing uses, or where there is potential loss of resources, such as fish, wildlife, and plant life. Other restrictions on hydroelectric generation may exist in some areas of the state. Applicants should consult with appropriate public and private agencies conceming restrictions before the application is filed and submit proof of that consultation with the application. Applicants wishing advice concerning potential restrictions should contact the OWRD in Salem.

Minor projects in Oregon are defined as those producing 100 theoretical horsepower (thp) or less. Major projects are those producing over 100 thp. An application must be filed for each hydropower project. A hydroelectric license is subject to all prior rights and established minimum streamflows, and wiil also be subject to all rights that may be established in the future for domestic, municipal, irrigation, or other beneficial consumptive uses.

Engineering plans and specifications are required for all major projects and are also required for minor projects that involve: 
- dams 10 feet or more in height;

- $\quad$ reservoirs that will impound more than 9.2 acre-feet $(3,000,000$ gallons);

- canals and/or pipelines that carry more than five cubic feet per second of water.

Licenses can be issued for up to 50 years. However, licenses for minor projects are normally issued for 20 years. Construction must begin within 1 year of the date the license is issued and be completed within 3 years, unless an extension of time is granted by the Water Resources Commission. The water right for a storage reservoir constructed as part of the project is covered under the license if the stored water is used only for power generation. If some or all of the stored water is used for other purposes such as irrigation, recreation, or fish culture, then surface water and reservoir permits must be obtained from the OWRD.

\section{Process for Submitting Applications}

For minor projects, license applications will normally be approved or denied within 60 days of submission unless there is a public interest issue. Such an issue would be raised if the proposed stream is important to a fishery or recreation area, or if there is evidence that there might be injury to other users.

For a minor license, the Water Resources Commission may waive any or all filings, hearings, and approvals. The term of the license and annual fees cannot be waived, however. The Commission's waiver authority is delegated to the Water Resources Director. A public hearing will be held only if the Commission deems it in the public interest to do so. Waivers are not given to an applicant who proposes to sell the power for profit.

A year or more is needed for approval or denial of major projects due to a more detailed application review and required public hearing.

\section{Table 4}

\section{Designated Resource Areas in Oregon}

\section{National parks}

National monuments

Wilderness areas established by federal law

Bureau of Land Management areas of critical environmental concern established under federal law

Wild and scenic rivers established under federal law

Estuarine sanctuaries established under public law 92-583

Federal research natural areas established under federal regulation

State parks and waysides

Scenic waterways designated under ORS Chapter 390

State wildlife refuges

State dedicated natural heritage areas established under ORS Chapter 273 


\section{Table 5}

\section{Special Management Areas}

National wildlife refuges

National recreation areas

State wildlife management areas

State forests

County parks

City parks

Special district parks

Sites listed in or determined eligible for inclusion on the National Register of Historic Places Areas managed by federal agencies for study, including a designation as a protected areas under federal law or regulation

Areas under study by state agencies for inclusion in or designation as a protected area under state statute or regulation

\section{Table 6}

\section{Public and Private Agencies}

Fish and Wildlife Resources

Oregon Department of Fish and Wildlife

U.S. Fish and Wildlife Service

National Marine Fisheries Service

Appropriate Indian tribes identified by the Legislative Commission on Indian Services

Northwest Power Planning Council, if the proposed project is within the Columbia Basin

\section{Water Quality: Department of Environmental Quality}

Historic, Cultural, and Archaeological Resources

State Historic Preservation Officer

Appropriate Indian tribes identified by the Legislative Commission on Indian Services

\section{Forestlands}

U.S. Forest Service

Bureau of Land Management

Oregon Department of Forestry

\section{Wetlands}

Oregon Division of State Lands

Oregon Natural Heritage Data Base

\section{Scenic-aesthetic Resources}

Appropriate local government planning departments (city, county)

Oregon Department of Environmental Quality (noise standards)

Federal managing agency, if public land

Oregon Parks and Recreation Division, Oregon Department of Transportation 
Table 6 conti nued

\author{
Recreation Resources \\ Oregon Parks and Recreation Division, Oregon Department of Transportation \\ Federal managing agency, if public land \\ Appropriate local government planning departments (city, county) \\ Land Use and Access \\ Appropriate local government planning departments (city, county) \\ Appropriate state land management agencies \\ Federal managing agency, if public land \\ Landowners, if private land \\ Threatened and Endangered Species \\ Oregon Department of Fish and Wildife \\ U.S. Fish and Wildlife Service \\ National Marine Fisheries Service \\ Oregon Natural Heritage Data Base (The Nature Conservancy) \\ Natural Communities and Geological Features \\ Oregon Natural Heritage Data Base (The Nature Conservancy)
}

If any portion of the project will be on land not owned or controlled by the applicant, the OWRD requires evidence that the necessary right-of-way or easement will be granted before a license will be issued.

\title{
Filing and Development Fees
}

Filing fees are required by law (ORS 540.270). Specific fee amounts are stated in Oregon Administrative Rules (OAR 690-51-400). Fees are based on the theoretical horsepower (hp) developed. For minor projects, a fee of $\$ 50$ is charged up to the first 25 thp and $\$ 2$ for each additional thp up to 100 .

For major projects, a fee of $\$ 50$ is charged and an additional fee, not to exceed $\$ 200$, will be charged to cover costs of recording, of publishing notice, and of determining if a preliminary permit or license should be granted. If approved, an additional fee of 5 cents for each thp is required before the preliminary permit or license can be issued. There is no additional charge for a license application when a preliminary permit has been issued for the project, unless the project has been enlarged. A fee of 5 cents per additional thp will then be added.

Upon issuance of a license for either a major or minor project, the holder pays an annual power development fee of $\$ 1$ per thp for the first 25 thp and 20 cents for each additional thp. 


\section{Oregon State Agencies' Responsibilities}

\section{Agency: Oregon Department of Environmental Quality (ODEQ) Statutory Authority: ORS Chapter 454}

The Oregon Department of Environmental Quality (ODEQ) reviews plans for hydroelectric projects to improve or maintain air, land, and water quality.

CDEQ issues permits for air emissions, water discharges, water or waste treatment, and solid w.aste disposal. Each permit lists operating conditions and pollution limits. We suggest you meet with the ODEQ regional office (the state is divided into five ODEQ administrative regions. ODEQ can help estimate environmental impacts and tell you which permits or standards apply to your project. Addresses are listed at the end of this section.

\section{Agency: Oregon Department of Fish and Wildlife (ODFW) Statutory Authority: ORS Chapters 497, 498, 501, 506, 507, 508, 509, 511, 513}

The Oregon Department of Fish and Wildlife (ODFW) consists of the Fish and Wildlife Commission, the director (appointed by the commission), and a statewide staff.

The commission formulates the general programs and policies of the state concerning the management of fish and wildlife resources and establishes seasons, methods, and bag limits for recreational and commercial take of the resource.

The ODFW is headquartered in Portland with regional offices in Newport, Clackamas, Corvallis, Roseburg, Bend, La Grande, and Hines. Twenty district offices are also staffed at strategic locations throughout he state. The ODFW operates a variety of facilities designed to enhance fish and wildlife resources, including 34 fish hatcheries, one game farm, numerous wildlife areas, public shooting grounds, hunting and fishing access sites, and several research stations.

\section{Agency: Oregon Department of Energy (ODOE) Statutory Authority: ORS Chapter 469}

The Oregon Department of Energy (ODOE) was established to provide comprehensive state leadership on energy planning and forecasting, to support research on alternate sources of energy, to be a central repository for energy data, to educate the public about energy problems and conservation, and to use private or federal funds to support these activities.

ODOE oversees three major programs including Energy Conservation, Policy and Resource Planning, and Nuciear Safety and Energy Facilities. ODOE's Small Scale Energy Loan Program makes long-term, low-cost loans for projects that conserve or produce energy.

ODOE administers federal programs for energy conservation in schools, hospitals, public care, and local govermment buildings. It also provides staff support for the Energy Facility Siting 
Council and the Energy Policy Review Committee. The director is responsible for supervising day-to-day functions of the department, supervising and facilitating work on siting as directed by the Energy Facility Siting Council, and adopting rules and issuing orders to carry out ORS Chapter 183 and the policy stated in ORS 269.010.

The director's office also is responsible for public information, writing and publishing a wide variety of handbooks and pamphlets for public distribution, maintaining film and publication lists, and arranging for public speaking engagements.

ODOE is divided into four divisions. The Nuclear Safety Division staffs the EFSC, discussed further in this guide. The Policy and Planning Division provides technical assistance to developers. The Conservation Services Division provides assistance to developers. The Business Energy Tax Credit Programs provides a 35 percent tax credit for businesses that install energy conservation, renewable resource, and recycling projects.

\section{Agency: Oregon Public Utility Commission (OPUC) Statutury Authority: ORS Chapter 757}

The Oregon Public Utility Commission (OPUC) consists of the members who regulate electrical and natural gas utilities, large water districts, telephone, and transportation industries. The OPUC must ensure that utilities provide consumers with adequate services at reasonable rates while eaming a fair retum on their investment (ORS 756-772).

The OPUC assists hydroelectric energy projects with safety codes and electrical power contracts. Safety codes govern equipment designed to transport gas or generate electrical power for transmission. OPUC has adopted the National Electric Code (NEC). Plants that connect with utility systems must comply with the NEC. OPUC will provide advice to small power producers and utilities over interpretations of the code.

The OPUC Utility Program makes an independent assessment of all utility rate proposals. It will not allow a utility to add a facility into its rate base if the power sales agreement is unfair to ratepayers. Utilities may ask OPUC to review a power sales contract before they sign it.

OPUC staff help the small power producer understand his rights in contract negotiations with a utility. If an impasse is reached in negotiating a contract, OPUC staff will clarify the rights of each party.

The OPUC believes that a properly structured competitive bidding process will benefit the public in Oregon. Therefore, the commission has directed each electric utility providing service in Oregon to use the competitive bidding process to obtain at least a portion of its electric resources in the future. The commission encourages active and enthusiastic participation, but is not requiring 
utilities to obtain all of their future power needs through the bidding process. In its review of each utility's least-cost plan, the commission will examine the utility's participation in the bidding process.

\section{Competitive Bidding Goals}

Energy resource acquisition via competitive bidding is a relatively new and evolving process within the electric industry. The main advantage of bidding is that it provides a means to identify and acquire least-cost resources which are available in the increasingly competitive electric generation marketplace. For Oregon to pursue competitive bidding, the process should satisfy the following goals:

1. Provide the opportunity to minimize long-term energy costs, subject to economic legal and institutional constraints;

2. Complement Oregon's least-cost planning process, as described in OPUC Order 89-507.

3. Not unduly constrain utility management's prerogative to acquire new resources through means other than competitive bidding;

4. Be flexible, allowing the contracting parties to negotiate mutually beneficial exchange agreements;

5. Be considered an understandable and fair process by all participating parties.

\section{Agency: Oregon Advisory Committee on Historic Preservation (OACHP) Statutory Authority: ORS Chapter 390}

The Oregon Advisory Committee on Historic Preservation (OACHP) consists of nine members recognized professionally in the fields of history, architectural history, architecture, archaeology, and other disciplines as may be appropriate; one member representing the public at large; and one American Indian. The members are appointed by the governor.

The committee is charged with reviewing nominations to the National Register of Historic Places form the state of Oregon, and recommending approved nominations to the State Historic Preservation Officer pursuant to the National Historic Preservation Act of 1966. The committee also reviews the Statewide Plan for Historic Preservation.

\section{Agency: Oregon Water Resources Department (OWRD) Statutory Authority: Constitution Article XI.D}

The Oregon Water Resources Department (OWRD) administers Oregon laws conceming the use of surface and groundwater. A Water Policy Review Board is composed of seven members appointed by the governor and confirmed by the Senate. It establishes policy to conform with the Surface Water Code and the Ground Water Act. 
OWRD permits allocate surface and groundwater and protect critical areas. Permits cover diversion of water, hydroelectric power siting, safety of dams, reservoirs, creation of irrigation districts, and ponding.

Distribution of the available water supply is carried out by 19 Watermasters (Appendix ID). If you intend to use or divert state protected water resources, consult your District Watermaster. Locate your project on the river basin map in the field office and obtain a permit application form.

\section{Agency: Oregon Energy Facility Siting Council (OEFSC)}

\section{Statutory Authority: ORS, Chapter 469}

The Oregon Energy Facility Siting Council (OEFSC), established under provisions of the state Energy Facility Siting Act, claims jurisdiction over certain energy facilities on all lands, private, state, or federally owned. Site certifications are required by OEFSC for any hydropower plant with a nominal electrical generating capacity of more than 25 megawatts; and high voltage transmission lines of more than 10 miles in length with a capacity in excess of 230,000 volts.

OEFSC has adopted general standards that apply to all energy facilities and require the following mandatory findings: 1) need for the proposed facility based on energy demand and economic prudence; 2) protection of public health and safety; 3) environmental protection; 4) beneficial use of wastes and byproducts; 5) conformance with statewide planning goals and comprehensive land-use plans; 6) protection of historical and archaeological sites; 7) no infringement on existing water rights; 8) necessary expertise to operate, construct, and retire the facility; 9) reasonable assurance of obtaining the necessary funds, and 10) identification of foreseeable socioeconomic impacts in the vicinity of the proposed facility (OAR 345-74-025).

A very important element of the state energy facility siting statutes, and a critical role of the implementing authority, is to provide for the coordination of permits and license applications through all state and local agencies affected by an application. Another important element is to coordinate with other agencies to make siting of all energy facilities a one-step process for applicants. This procedure saves both time and money, and ensures that all applications are handled and evaluated in a consistent manner. Once a siting certificate for a transmission or energy conversion facility is granted, all state and local agency permits and licenses must automatically be granted. Each permitting agency, however, retains the authority to enforce conditions and requirements of the permit or license issued. Examples of required permits include: drilling, conditional land use, construction, air emissions, and disposal of liquid or solid wastes. 
Agency: Building Codes Agency (BCA)

Statutory Authority: ORS Chapter 479

The Oregon Building Codes Agency (BCA) regulates hydroelectric energy projects through local building departments. In less populated areas, $11 \mathrm{BCA}$ field offices issue permits and conduct inspections.

Local building, electrical, mechanical, and plumbing permits ensure that facilities are built according to the codes adopted by the BCA. Local officials issue permits and conduct inspections. Local building departments review construction plans to ensure that they conform to the fire, life, and safety provisions adopted by the Executive Department Office of the Fire Marshall. BCA professional licensing and advisory boards list professional engineers, architects, and landscape architects licensed to practice in the state.

\section{Agency: Executive Department/Fire Marshall}

Statutory Authority: ORS Chapter 476

Local building departments review construction plans to ensure that they conform to the fire, life, and safety provisions adopted by the Office of the Fire Marshal. The division has 12 field offices.

\section{Agency: Oregon Department of Parks and Recreation (ODPR) Statutory Authority: ORS Chapter 390}

The Oregon Department of Parks and Recreation (ODPR) is responsible for the acquisition, improvement, maintenance, and operation of Oregon's state park system. The system is directed by the state parks administrator through a headquarters staff in Salem and five regional park supervisors stationed throughout the state.

In addition to operating state parks, the division gives technical assistance to local government agencies on park matters, develops and maintains the Statewide Comprehensive Outdoor Recreation Plan, and administers the Federal Land and Water Conservation Fund matching grant program in Oregon. The division also administers several special programs.

\section{Agency: Oregon Division of State Lands (ODSL)}

\section{Statutory Authority: ORS Chapter 273; OAR 141, Division 75; Constitution Article XI}

State Land Board: The State Land Board is composed of the governor, who serves as chair, the Secretary of State, and the State Treasurer. Under constitutional and statutory guidelines, the Board is responsible for managing the assets of the Common School Fund as well as for additional functions assigned by the Legislature. 
The Common School Fund was established as a constitutional trust when Oregon was admitted to the union on February 14,1859. At that time, the federal government granted to the state the 16 th and 36th sections of every township or other lands "in lieu" of these sections, to support the public schools. The fund's land base now includes:

- more than 600,000 acres of grazing and agricultural land

- 132,000 acres of forest land, including the Elliott State Forest in Coos and Douglas counties

- 800,000 acres of off-shore land and estuarine tidelands

- submerged and submersible lands of the state's navigable waterways

The Oregon Division of State Lands (ODSL) manages these lands. The Director is appointed by the Land Board.

In addition to its land and fiscal management functions, the Division provides a number of other public services, many of which are legislatively assigned. One such responsibility is administering the state's removal-fill law, which protects Oregon's waterways from uncontrolled alteration. The permit-review process involves coordination with the applicant, adjacent land owners, and natural-resource and land-use agencies from local through federal levels.

Other responsibilities of the ODSL include: leasing state-owned mineral rights for exploration and production of oil, gas, hard minerals, and geothermal energy; management of Tongue Point Marine Industrial Site in Astoria; maintenance of historical records related to early land transactions, including deeds, leases, and plats; performance of administrative functions for the Natural Heritage Advisory Council, established by the Legislature in 1979 to identify representations of the range of ecosystem types found in Oregon; and management oversight and performance of administrative services for the South Slough National Estuarine Reserve, established by the federal government in 1974 as one element of the Oregon Coastal Zone Management Program.

\section{Agency: Oregon Department of Forestry (ODF) Statutory Authority: ORS Chapter 526}

The Oregon Department of Forestry (ODF) is under the direction of the State Forester who is appointed by the Board of Forestry. The statutes direct the State Forester to act on all matters pertaining to forestry in the protection of forest lands and the conservation of forest resources.

These activities include: fire protection for 16 million acres of private, state, and federal forests (over one-half the forest lands in Oregon); the detection and control of harmful forest insect pests and forest tree diseases on 12 million acres of state and private lands; the rehabilitation and management of 785,300 acres of state-owned forest lands; and operation of a 15-million-tree forest nursery. The Department also administers the Oregon Forest Practices Act, Log Patrol and Log 
Brand Acts, Small Tract Optional Tax Law, forest land classification, forestry assistance to Oregon's 24,000 non-industrial private woodland owners, forest resource planning, and forest products marketing.

\section{Agency: Oregon Department of Transportation (ODOT) Statutory Authority: ORS Chapter 184}

Oregon Transportation Commission: The Commission develops and maintains state transportation policy and a comprehensive long-range plan for a multimodal transportation system, which encompasses economic efficiency, orderly economic growth, safety and environmental activities. Transportation planning must use the potential of all existing and developing modes of transportation. The plan includes aviation, highways, public transit, rails, and bike paths.

Policies for the operation of the Department are established by the Commission in a manner consistent with ORS 184.610 to 184.640 . The Commission coordinates and administers programs relating to aeronautics, highways, motor vehicles, and public transit.

The Govemor appoints the five members for 4-year terms, which expire June 30 of the years indicated. Members are appointed with consideration for the different geographic regions of the state, with one member being a resident of the area east of the Cascade Range. No more than three members can belong to one political party.

Highway Division: ' he Highway Division's mission is to design, build, and maintain quality highways and bridges. The state's system must be safe, cost effective, and provide efficient access throughout the state. It should be planned and maintained to complement Oregon's natural beauty and to help spur economic development. The Division maintains over 7,500 miles of paved highways in the state system. The Division serves the public locally through five regional offices, with headquarters in Salem.

\section{Oregon Permitting and Licensing Requirements}

\section{Water Quality/Water Use}

The Oregon Department of Environmental Quality (ODEQ) issues two permits for air emissions, water discharges, and solid waste emissions. The ODEQ permit process is shown in Figure 9, and the approximate time required to obtain the required permits is shown in Figure 10. 


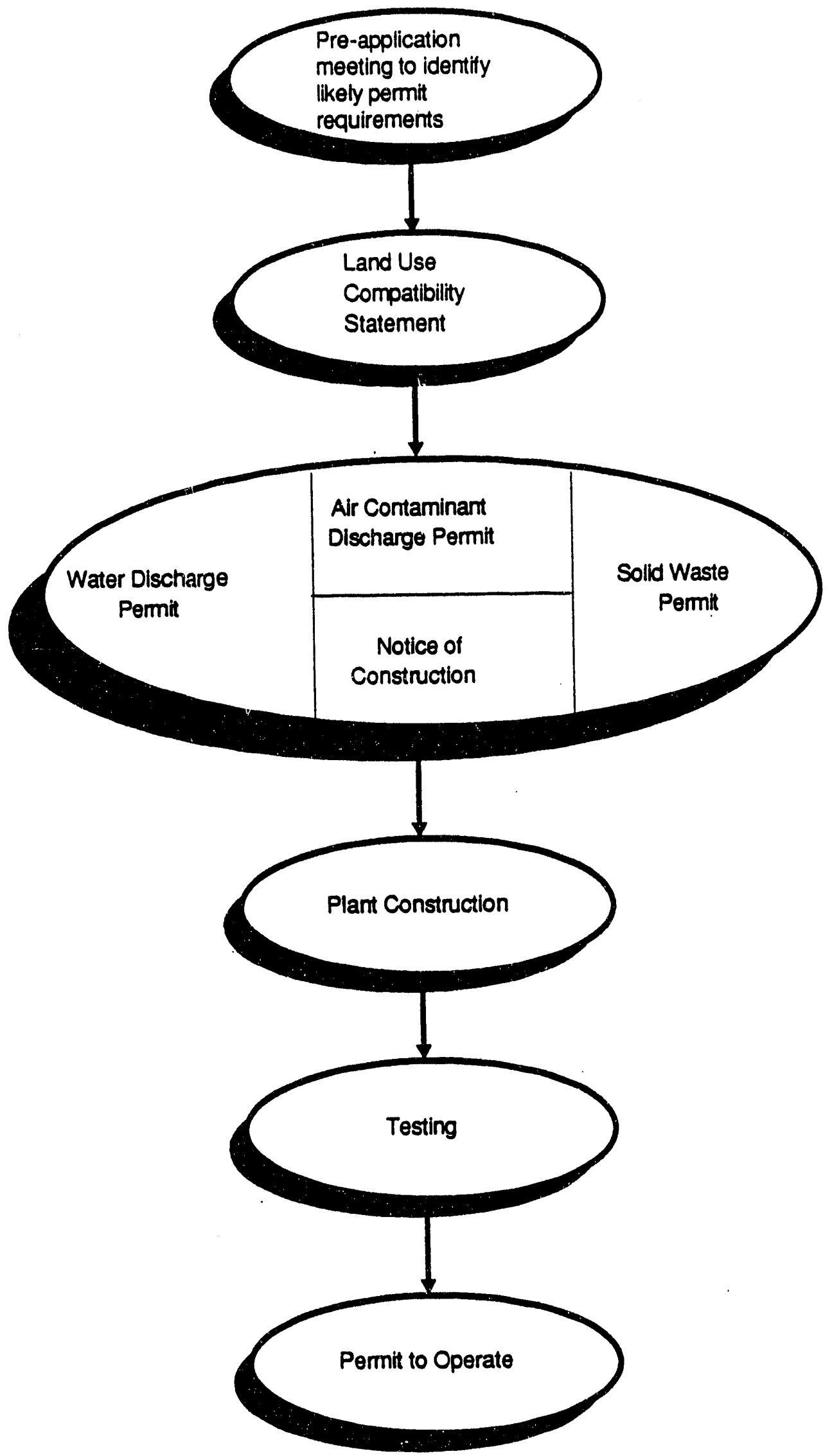

Figure 9: Department of Environmental Quality Permit Process Diagram 


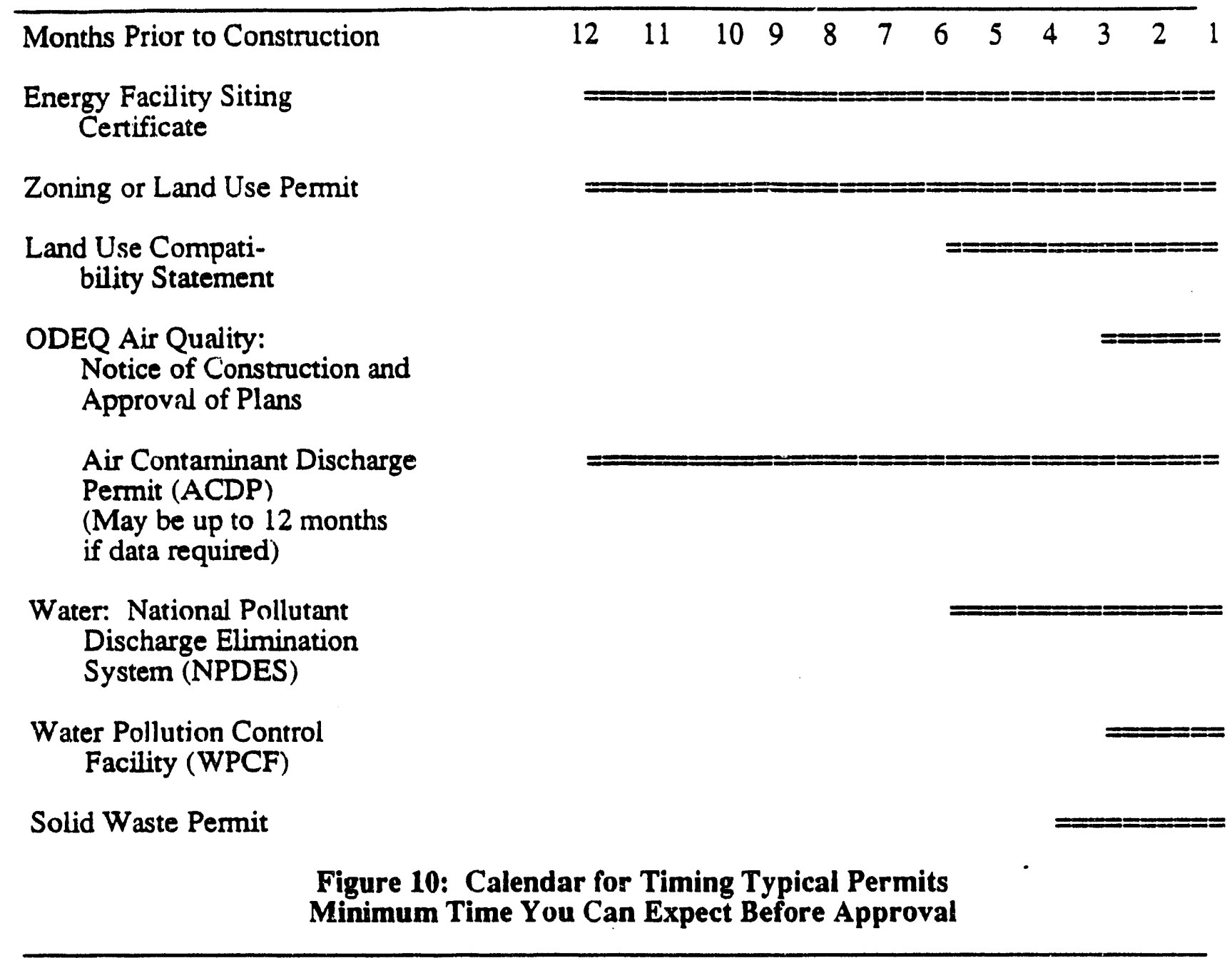

Two relevant water quality permits are issued:

1. National Pollutant Discharge Elimination System (NPDES) permits cover all waste water discharges to surface waters. The NPDES is a federal program administered by the state. NPDES covers commercial or industrial plants, municipal sewage treatment plants, confined animal feed operations with point discharges, and mining operations.

2. Water Pollution Control Facility (WPCF) permits apply to waste waters directly disposed of on land or injected into the ground with no direct discharge to surface waters. Land irrigation, evapo-transpiration lagoons, and industrial seepage pits are examples. WPCF is a state program.

The Oregon Water Resources Department regulates the use of state surface waters from rivers and streams, and groundwater from wells or aquifers. 
Permit or Regulation: National Pollutant Discharge Elimination System (NPDES)

Statutory Authority: OAR 340-45-005--340-45-070, ORS 468

Agency: Oregon Department of Environmental Quality (ODEQ), Water Quality Division

This permit applies to any project that will release wastes into public waters, unless:

a. The discharge is into a sewage system that has valid permits, such as a municipal system, and you have obtained a permit to discharge into that system; or

b. The Cregun Department of Environmental Quality (ODEQ) has written, in reply to your application, that no NPDES permit is needed.

ODEQ has established water quality goals and regulations for 19 different water basins within Oregon. Water quality permit conditions are considered on a case-by-case basis. The size of the receiving stream and activity (see Table 7) are considered.

A permit can usually be issued within 60 to 120 days of receipt to of a completed application. There is a $\$ 50$ riling fee. Application processing fee is from $\$ 50$ to $\$ 1,000$. The most likely cost is $\$ 250$. Arinual compliance determination fees range from $\$ 100$ to $\$ 1,325$.

\section{Table 7}

NPDES Permit Application Forms

(OAR 340-45-(1)30)

Permit Category

Any industrial, commercial, manufacturing, or mining activity

\section{Application Form}

Standard Form C [EPA Form 7550-23A (7-73)]

a. In quantities exceeding 50,000 gallons on any day of the year

b. In quantities of 50,000 gallons or less but which discharges a toxic pollutant

\section{Permit or Regulation: Water Rights Permit}

Statutory Authority: ORS Chapter 537

Agency: Oregon Water Resources Department (OWRD)

The Oregon Water Resources Department (OWRD) regulates the use of state surface waters from rivers and streams, and groundwater from wells or aquifers. 
Any project that will use any surface water (lakes, streams, rivers, waters stored in reservoirs, or other surface sources) or more than 5,000 gallons per day of groundwater must apply for a Water Rights Permit.

Oregon law states that all Oregon waters from almost all sources belong to the public. This permit grants a right to use the public's water for beneficial purposes.

The following dates are set by law:

Construction must begin within 1 calendar year after the permit is granted. (Construction may mean purchase of equipment.) No extension of time is allowed during this first year. Each permit is issued for only 1 year.

The developer has until October 1 of the next year to complete construction, and until October 1 of the year following to begin use. These latter two dates can be extended if satisfactory progress is being made. The developer should request a time extension from OWRD if necessary.

After water usage begins, the Watermaster's staff will inspect the facility. Water must be used for its intended purpose. The developer will not be allowed to use more water than the permit grants. If less water is being used, the permit will be modified.

Special standards apply to Wild and Scenic Rivers.

A 30-day legally-required waiting period begins when application is received. OWRD distributes a list of applications each week. Protests may be filed during this period. OWRD grants the permit within 60 days after application. If no water is available, the application and fee are retumed.

\section{Facility Siting}

\section{Permit or Regulation: Energy Facility Siting}

Statutory Authority: ORS 469.320-469.520; OAR Chapter 345, Division 111; ODOE Siting Division will send copies of all pertinent laws and rules Agency: Oregon Energy Facility Siting Council (OEFSC)

This permit applies to power plants that produce more than $25 \mathrm{MW}$ of electricity. Prior to applying for a site ce :tificate, applicants must submit a Notice of Intent (NOI). The NOI describes the project and its impacts.

The Oregon Energy Facility Siting Council (OEFSC) is the state's authority for siting major power plants. It regulates and monitors construction and operation. Figure 11 shows the OEFSC site certification application process. 


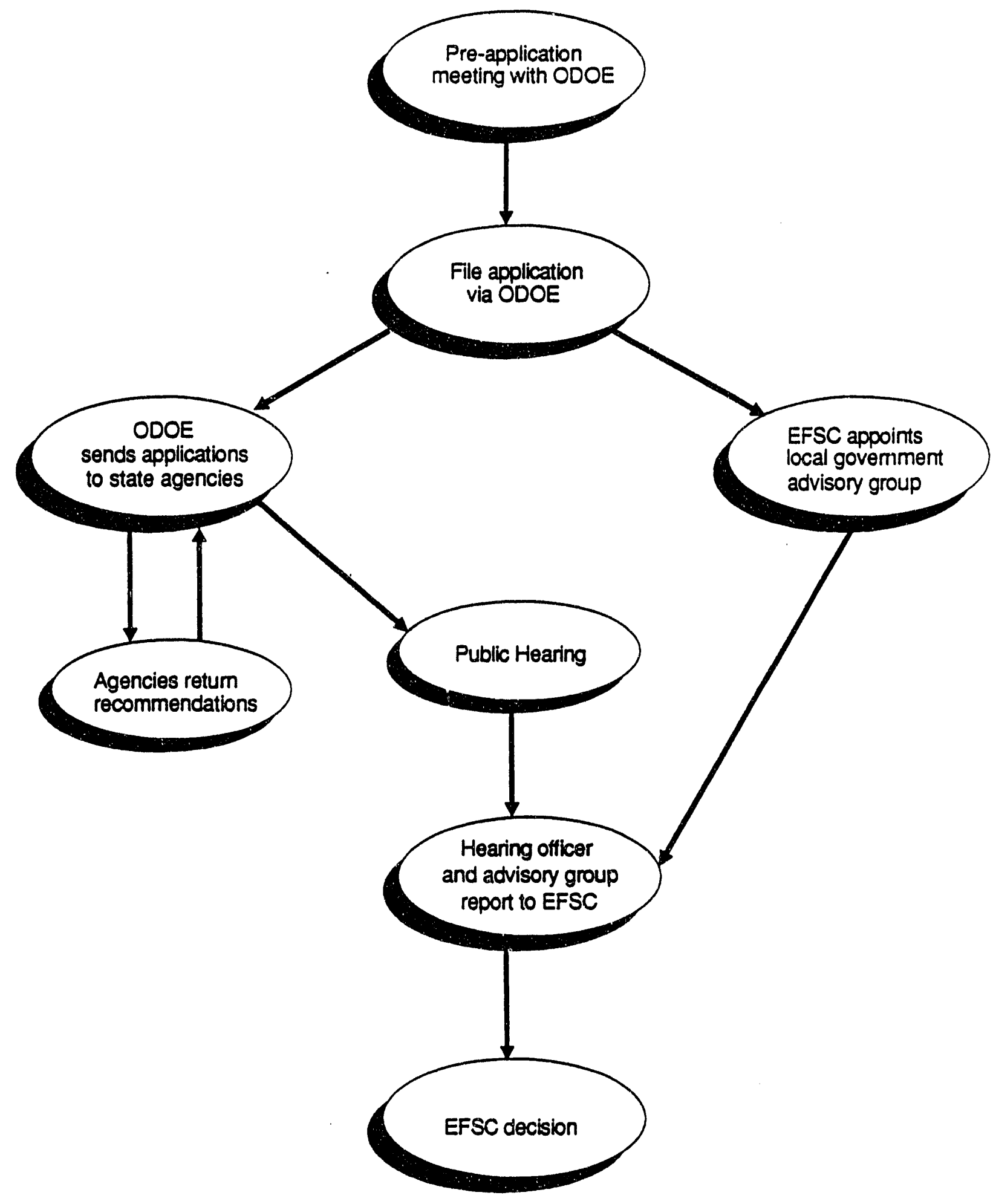

Figure 11: Energy Facility Siting Council

Application Process Diagram 
OEFSC guides all permit applications. It coordinates project review by state and local agencies. Its final decision is binding on all state and local agencies. All interested persons and government agencies have access to the OEFSC process. Energy facility siting includes a public hearing.

Each site certificate includes conditions for construction and operation. These conditions are proposed, debated, and adopted through a contested hearing.

It takes approximately 6 to 12 months after the complete application is filed to receive the permit.

\section{Land Use}

\section{Oregon's Land Use Planning Process}

The Land Conservation and Development Commission (LCDC) supervises planning in Oregon through its staff, the Land Conservation and Development Department. LCDC adopted 18 statewide planning goals from 1974 to 1976 (Table 8). Local governments adopt a comprehensive plan and state how planning, zoning, and development will be consistent with LCDC goals. The land use approval process is shown in Figure 12. Local plans are approved by LCDC. All cities and counties have LCDC-approved comprehensive plans.

\section{Table 8}

\section{Titles of LCDC Statewide Planning Goals}

1. Citizen Involvement

2. Land Use Planning

3. Agricultural Lands

4. Forest Lands

5. Open Spaces, Scenic and Historic Areas, and Natural Resources

6. Air, Water, and Land Resources Quality

7. Areas Subject to Natural Disasters and Hazards

8. Recreational Needs

9. Economy of the State

10. Housing

11. Public Facilities and Services

12. Transportation

13. Energy Conservation

14. Urbanization

15. Willamette River Greenway

16. Coastal Shorelands

17. Beaches and Dunes

18. Ocean Resources

For a complete description, request "Statewide Planning Goals and Guidelines" from LCDC. 


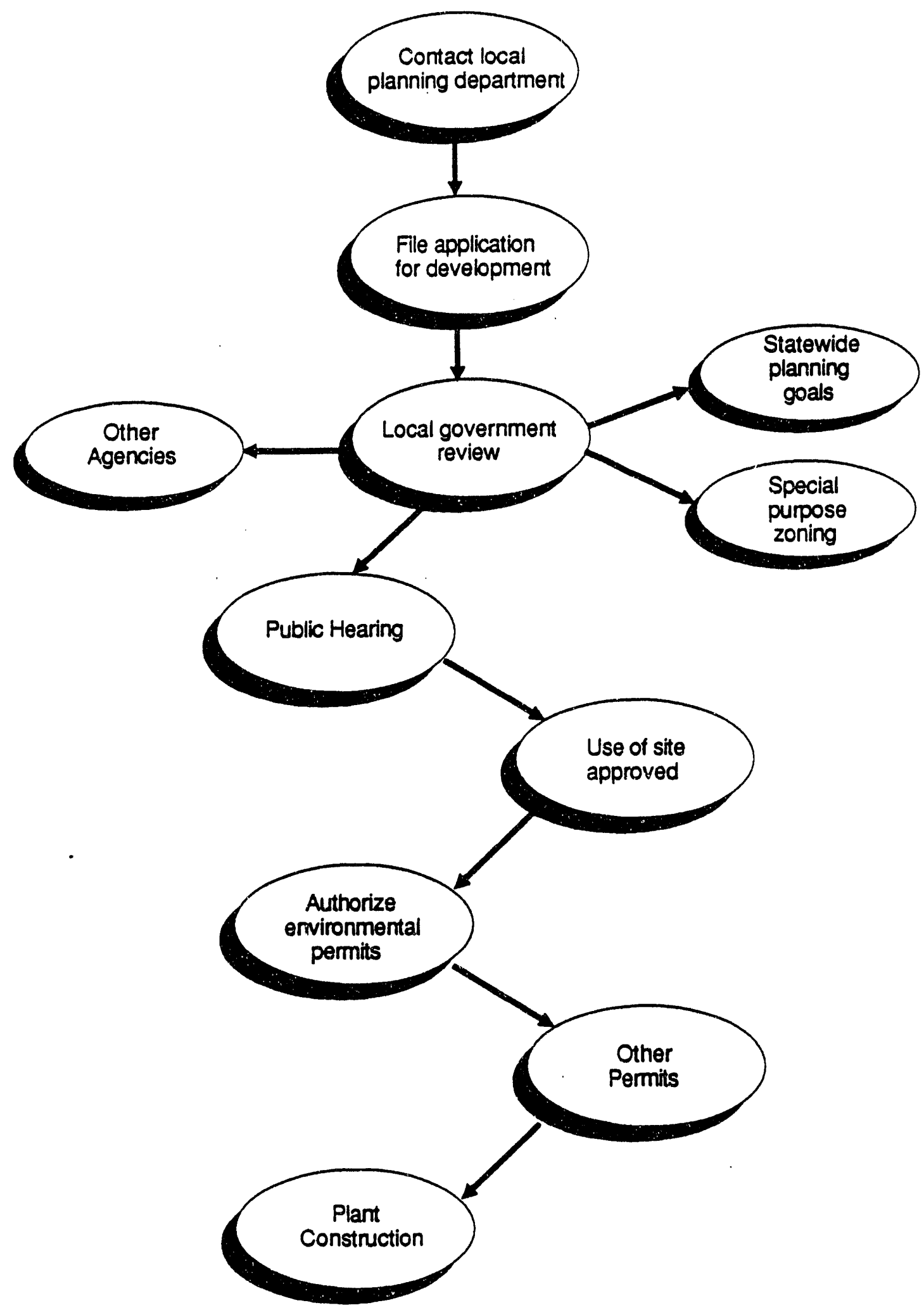

Figure 12: Local Government Land Use Approval Land Use Planning and Permit Process 


\title{
Coordination with Other Agencies
}

ODEQ requires a Land Use Compatibility Statement to be signed by a representative from local government. OEFSC appoints advisers from the local governing body. Other agencies also require local government authorization before permits are issued.

\section{Statement: Land Use Compatibility Statement}

Statutory Authority: ORS Chapter 197; OAR, Divisions 30 and 31

Agency: Oregon Department of Environmental Quality (ODEQ)

An Oregon Department of Environmental Quality (ODEQ) permit will not take effect until you have a Land Use Compatibility Statement (Table 9). The Statement shows that the proposed project complies with LCDC's statewide planning goals or with an acknowledged land use plan.

The time required to obtain this permit varies according to project size and local land use permit process.

\section{Table 9}

\author{
When to Submit Land Use Compatibility Statements \\ Statement Required BEFORE Permits Become EFFECTIVE \\ Air Contaminant Discharge Permit (ACDP) \\ Statement Required BEFORE Permit is ISSUED \\ Water Pollution Control Facility (WPCF) \\ National Pollutant Discharge Elimination System (NPDES) \\ Statement Required WITH Application \\ On-site Sewage Disposal Permits \\ Solid Waste Permits \\ Hazardous Waste Disposal License \\ Sewage and Waste Water Industrial Permits
}

Permit or Regulation: Qualifying Facility Certification

Statutory Authority: ORS Chapter 758

Agency: Oregon Public Utility Commission (OPUC)

The applies to any cogeneration and small power production facility that, by definition produces energy primarily by the use of biomass, waste, solar energy, wind power, water power, or geothermal energy.

Procedures for obtaining certification are the same as the FERC QF regulation. It will take about 90 days to obtain the certification. 


\section{Safety and Health}

State law requires that construction plans be reviewed for compliance with fire, life, and safety provisions of the Uniform Building Code (UBC) and Uniform Mechanical Code (UMC). The Building Codes Agency process for such review is shown in Figure 13. Further information regarding fire, life, and safety reviews may be found in ORS Chapters 447,453, 454, and 476. All potential developers should discuss the codes with the Building Codes Agency.

\section{Miscellaneous Permits or Agency Review}

Permit or Regulation: Noise Control for Industry and Commerce

Statutory Authority: ORS Chapter 467; OAR 340, Division 35

Agency: Local Planning Agencies

Local agencies control noise through standards, review, and mitigation actions (see Tables 10 , 11 , and 12). There is no noise permit. A compliance schedule for certain high noise sources may be required, with intended actions listed.

Table 10

Industrial and Commercial Noise Source Standards (OAR 340-35-035)

Allowable Statistical Noise Levels in Any One Hour

7 a.m. - 10 p.m. 10 p.m. - 7 a.m.

L50 - $55 \mathrm{dBA}$

$\mathrm{L}_{10}-60 \mathrm{dBA}$

$\mathrm{L}_{1}$ - $75 \mathrm{dBA}$

L50 - $55 \mathrm{dBA}$

$\mathrm{L}_{10}$ - $55 \mathrm{dBA}$

$L_{1}-60 \mathrm{dBA}$

\section{Table 11}

Industrial and Commercial Noise Source Standards for Quiet Areas

(OAR 340-35-035)
Allowable Statistical Noise Levels in Any One Hour
7 a.m. - 10 p.m. 10 p.m. - 7 a.m.
L50 - $50 \mathrm{dBA}$
$\mathrm{L}_{10}$ - $55 \mathrm{dBA}$
$\mathrm{L}_{1}$ - $50 \mathrm{dBA}$
$\mathrm{L}_{50}$ - $45 \mathrm{dBA}$
$\mathrm{L}_{10}-50 \mathrm{dBA}$
$\mathrm{L}_{1}-55 \mathrm{dBA}$ 


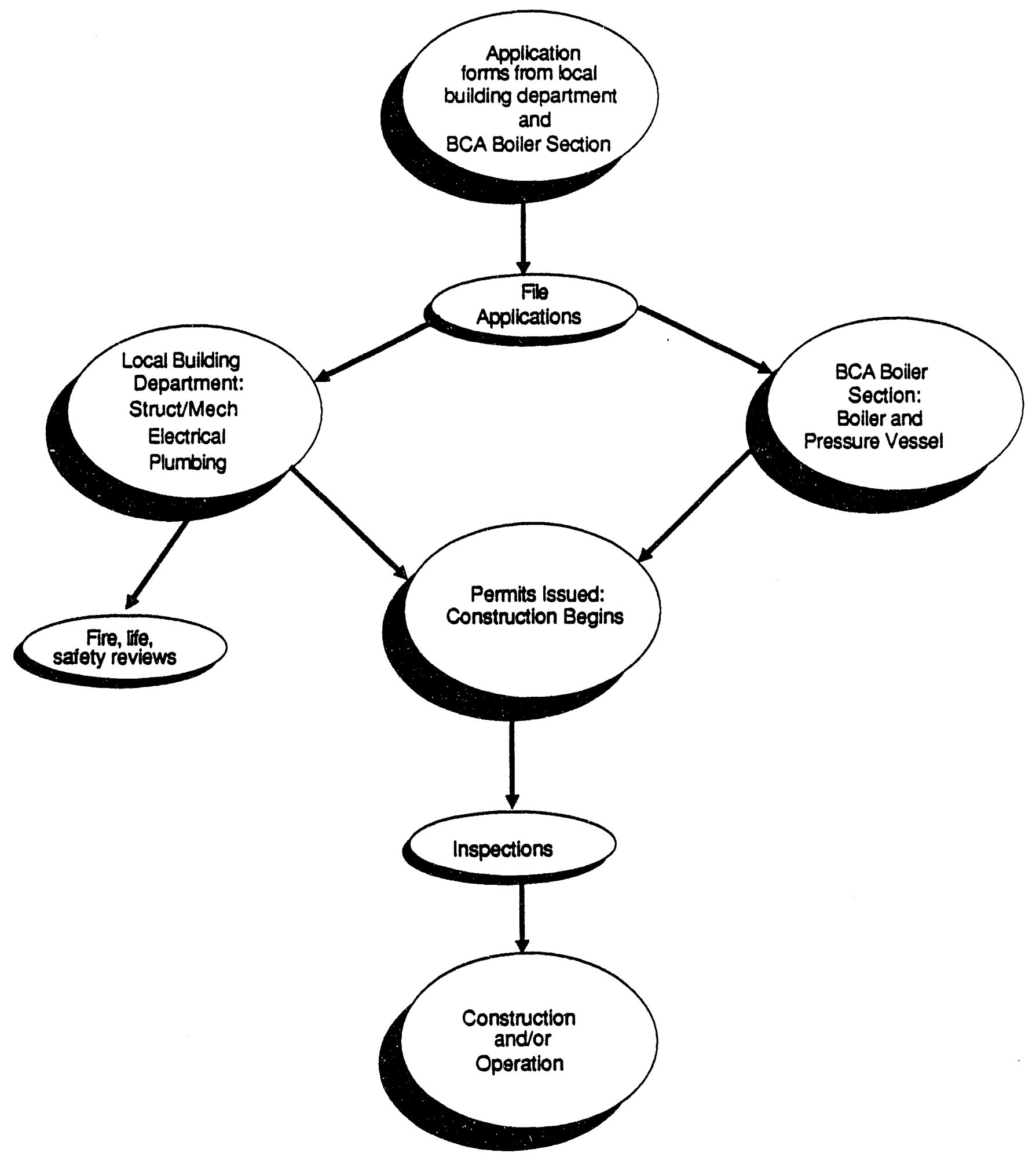

Figure 13: Building Codes Agency Building Permit Process 


\section{Table 12}

\section{Median Octave Band Standards for Industrial and Commercial Noise Sources}

(OAR 340-035)

\begin{tabular}{ccc}
\multicolumn{3}{c}{ Allowable Octave Band Sound Pressure Levels } \\
Octave Band Center \\
Frequency \\
Hz & 7 a.m. - 10 p.m. & 10 p.m. -7 a.m. \\
31.5 & 68 & 65 \\
63 & 65 & 62 \\
125 & 61 & 56 \\
250 & 55 & 50 \\
500 & 52 & 46 \\
1,000 & 49 & 43 \\
2,000 & 46 & 40 \\
4,000 & 43 & 37 \\
8,000 & 40 & 34
\end{tabular}

If there is reason to believe that anyone may object to the noise levels to be generated by a new facility, an optional pre-construction review by the local planning agency should be requested. The developer should provide details of the type of equipment to be used, its location, and barriers to noise transmission on the site.

Sources exempt from noise regulations include:

- tire or road vehicle noise if the vehicles meet standards

- construction site activity

- capital equipment construction or maintenance

- agricultural activity

- tree harvesting

- other exceptions authorized by ODEQ

\section{A-95 Review}

When a project receives financing from federal agencies, the local planning department coordinates an A-95 review. Federal and state agencies like the Historic Preservation Office, Fish and Wildlife, Department of Energy, and others will be asked to comment. A-95 review will extend time for land use approval.

\section{Local Permitting and Licensing Requirements}

Local govemments such as cities, counties, road districts, flood control districts, and drainage districts will have some jurisdiction over hydropower development. Early in the development process, a developer should contact city and county planning and public works departments. 
These departments should be able to inform the developer of all local permits the project will require. All local permit requirements must be satisfied prior to or concurrently with applications for use and occupancy of federal land and application to the Federal Energy Regulatory Commission for exemption or license.

The county planning department can inform the developer of any zoning and land use restrictions. Most counties also have planning and zoning commissions that will review project plans for compliance with comprehensive plans, zoning regulations, and needs for conditional or special use permits. Conditional use permits may be required for projects requiring the use of or the crossing of land under county jurisdiction. Generating facilities impacting only the developer's property should encounter few problems. More substantial generating facilities may be referred to hearings before the planning commission or county commissioners to determine if the project is in the public interest.

Counties may also have some jurisdiction over construction in or near defined flood plains and over use of, or construction near, county highways. The county courthouse, the county zoning administrator, and the county highway district are the best contacts for determining what permits or approvals will be required. For those areas under county jurisdiction, building, plumbing, and electrical permits from the public works or building department are generally required. The project plans must be reviewed for compliance with building and electrical code requirements.

If a proposed site is within a city's limits or within its area-of-impact, appropriate contact should be made with city officials regarding building permits, zoning regulations, flood plain construction, and highway usage. Contact the city hall of the nearest city for a determination of the required permits and approvals and jurisdiction.

\section{Determining Which Permits are Required}

To enable a developer to determine what local permits are necessary for a particular site, and for guidance in obtaining local permits, the following guidelines are provided.

- Determine with certainty within what local jurisdiction the project site lies. Assumptions about jurisdiction are often inaccurate. Even if a site is within the county, it is possible it may be within a city's Area of Impact, which would give the city certain jurisdiction over the project.

- Contact agency staff early to obtain information about permits and to discuss your plans. Go into their office in person to make personal contact and to show your commitment to expediting the permitting process.

- Determine what permits will be required for the proposed project; what information should be provided; the process that will be followed; and time frames, including submittal dates, hearing dates, and the time within which a decision can be expected. 
- Get copies of the applicable regulations so you can personally review them and the evaluation criteria. Ask questions if the written regulations vary from information the staff has provided.

- In the case of more discretionary permits, ask the staff about the likelihood of approval: also what might help to speed up the process and decision.

- Submit a complete application. Incomplete applications will result in processing delays.

- Attend all meetings where the application will be discussed. If there is no one to respond to questions, delays may occur or the permit may be denied.

\section{Land Use}

Permit or Regulation: Land Use or Zoning

Statutory Authority: ORS Chapter 454

Agency: City or County Planning Department

Any commercial, agricultural, or industrial project will be subject to land use and/or zoning regulations. The local planning department must approve the use of a site for energy conversion before plans can be submitted for building permits. Some local governments also require an architectural design review after the use of the site has been approved.

If the energy conversion process does not fit the site zoning class, a conditional use permit (CUP), or an amendment to the General Plan may be necessary.

An application for use of a site is considered during a public hearing where it is denied, approved, approved with conditions, or continued. A continuance refers the application back to planning staff for further review prior to another hearing. At the end of the process, the applicant will receive a letter that will approve or deny the intended use of the site.

Approval is complex. Projects are reviewed to assure protection of public health, safety, and general welfare; to comply with statewide planning goals; and to comply with a city or county comprehensive plan. Local government must: coordinate with other state and federal agencies; consider special purpose zoning like historic preservation sites; and consider water quality, soils suitability, fish and wildlife, noise, and public roads.

It generally takes approximately 60 to 120 days to approve a site. Approval can take over a year if the project is extremely complex or controversial. 


\section{Construction}

Permit or Regulation: Building (Building, Electrical, Mechanical, Plumbing)

Statutory Authority: ORS Chapter 479

Agency: City or County Building Department

This permit applies to all hydroelectric energy projects. Building permits are issued by the local building department. The permits ensure that construction plans meet the state adopted Uniform Building Code (UBC) or the Uniform Mechanical Code (UMC). Cities and counties differ in the amount of responsibility they asssume for plan review. and inspection. The state Building Codes Agency assists some areas through its field offices.

Building permits are not issued until the use of the site is approved by the planning department. Buildings more than 20 feet in height or 4,000 sq. $\mathrm{ft}$. in size, and energy plants and processes that require engineering judgment or affect public health and safety must be designed by a licensed architect or engineer. Electrical plans must be stamped by a registered electrical engineer.

Most permits are granted within 3 weeks of application. Complex plans may require a longer review period. 


\section{Permit Summary Sheet WASHINGTON}

Permitting

Agency

MAJOR FACILITY SITING/ENVIRONMENTAL IMPACT

WA Energy Facility Site Evaluation

State Environmental Policy Act

WEFSEC $>250 \mathrm{MW}$

WDOE

\section{AIR QUALITY}

Buming Permit

New Source Conatr. Approval

WDNR,APCA

WDOE or

Local Air Auth.

\section{WATER QUALTYYWATER USE}

Water Right

Water Quality Certification

Short-term Modification of Water Quality Criveria

Drilling Bond

Permit to Commence Drilling, Redrilling, or

Deepening

Flood Control Zono Permit

Underground Injection Control Permit

National Pollutant Discherge Elimination Sya.

Stave Wasto Discharge Permit

Hydraulic Project Approval

Public Waver Supply Approval

Surface Water Drainage Plan Approvals

Westewater Facilities Plan Approval

LAND USE

Geothermal Leasing

Archeoological Approval

Section 106 Review

Surface Mining Permit

Dumping Permit

Right-of-Way or Rued Use

Application to Purchese Valuable Material

Permit to Temporarily Remove or Destroy

Survey Monument

Special Motor Vehicle Use

Shoreline Subatantial Develop. Permit

Zoning Conditional Use Permit

Utility Permit

Permit to Operate Ovenweight Vehicles

on City or County Rouds

Forest Practices Approval

CONSTRUCTION

\section{Buming}

Commercial Building Permit

Plumbing Permit

Grading Permit

Sewage Holding Tank Varimce

Westewater Facilitios Plan Approval

SAFETYAREALTH

Dam Sufety Construction/Reservoir

Operation Permits

Solid Wasce Disposal Permit

Hezerdous Waste Disposal Permit

Boiler License

Public Waver Supply Approval

\section{OTHIER}

Cogeneration and Small Power

Production Fucilities Certification

\section{Agencter Kay}

APCA Air Pollution Control Authority

WDNR Wehington Departmont of Natural Resources

WDOT Weahington Department of Trensportation

WDSHS Washington Department of Social and Health Services

WDOE Washington Departument of Ecology

WEFSEC Energy Fucility Site Evaluation Council

WDF Washington Dopartment of Fisherie

WDW Washington Department of Wildlife

WOAHP Office of Archecological and Historic Preservation

WUTC Utilitios and Transportution Commission

WDOE

WDOE

WDNR

WDNR

WDOE

WDOE

WDOE

WDF/WDW

WDSHS

County

WDOE

WDNR

WOAHP

WDNR

WDNR

WDNR

WDNR

WDNR

WDOT

County/WDOE

County

County

City/County

WDNR

WDNR

County

County

County

County

WDOE

WDOE

WDOE

WDOE

$?$

WUTC/FERC
Thermal Thermal Trans-
Resources Resources
$<250 \quad>250 \quad \begin{gathered}\text { mission } \\ \text { Lines }\end{gathered}$ Hydro eration Wind Biomass thermal 


\section{Chapter 5 The Washington State Process}

The Washington Department of Ecology (WDOE), Washington Department of Fisheries (WDF), Washington Department of Wildlife (WDW), and the Washington State Energy Office (WSEO) should be contacted during the early planning stages of a project. The staffs of these agencies may identify potential problems and issues related to the proposal and assist in outlining ways to improve or expedite the planning and licensing process.

The policies of the individual state agencies toward hydroelectric development in the state of Washington vary considerably. Below is a brief policy summary for each significant state agency involved in permitting and regulating hydroelectric developments.

\section{Washington State Agencies' Responsibilities}

\section{Agency: Washington Department of Ecology (WDOE) Statutory Authority: RCW 43.21A.040}

As the state environmental management and protection agency, the Washington Department of Ecology (WDOE) is responsible for ensuring that the water and related land resources of the state are protected and fully utilized for the greatest benefit to the people of the state. WDOE administers several state permits designed to ensure environmentally sound, geotechnically safe hydroelectric project. WDOE involvement in the small-scale hydroelectric project permitting process is depicted in Figure 14. These permits must be obtained prior to beginning construction of a project in the state of Washington. Prior to approving water rights for projects, WDOE ensures that the affected stream or reach is provided with minimun instream flows necessary to preserve wildlife, fish, scenic, recreation, aesthetic, and other envi-onmental values, including water quality. WDOE processes water right permits that are required before the construction of any water well. A water right, if needed, should be applied for well in advance of construction. WDOE will inspect the site, require publication of a public notice, and attempt to resolve any protests filed. A permit allowing construction of the project may be issued if water is available, no existing water rights are affected, and the project would not be detrimental to the public welfare. A final certificate of water right is issued after the project is completed and water is put to use.

Instream flow requirements are specified as a condition of the water right permit when issued. These flows may be derived from project-specific instream flow studies performed by the applicant or previously developed by WDOE and adopted as state regulations. Sufficient flows are required to be released to protect and preserve the instream resources present in the stream including fish, wildlife, aesthetics, recreation, navigation, and water quality. 


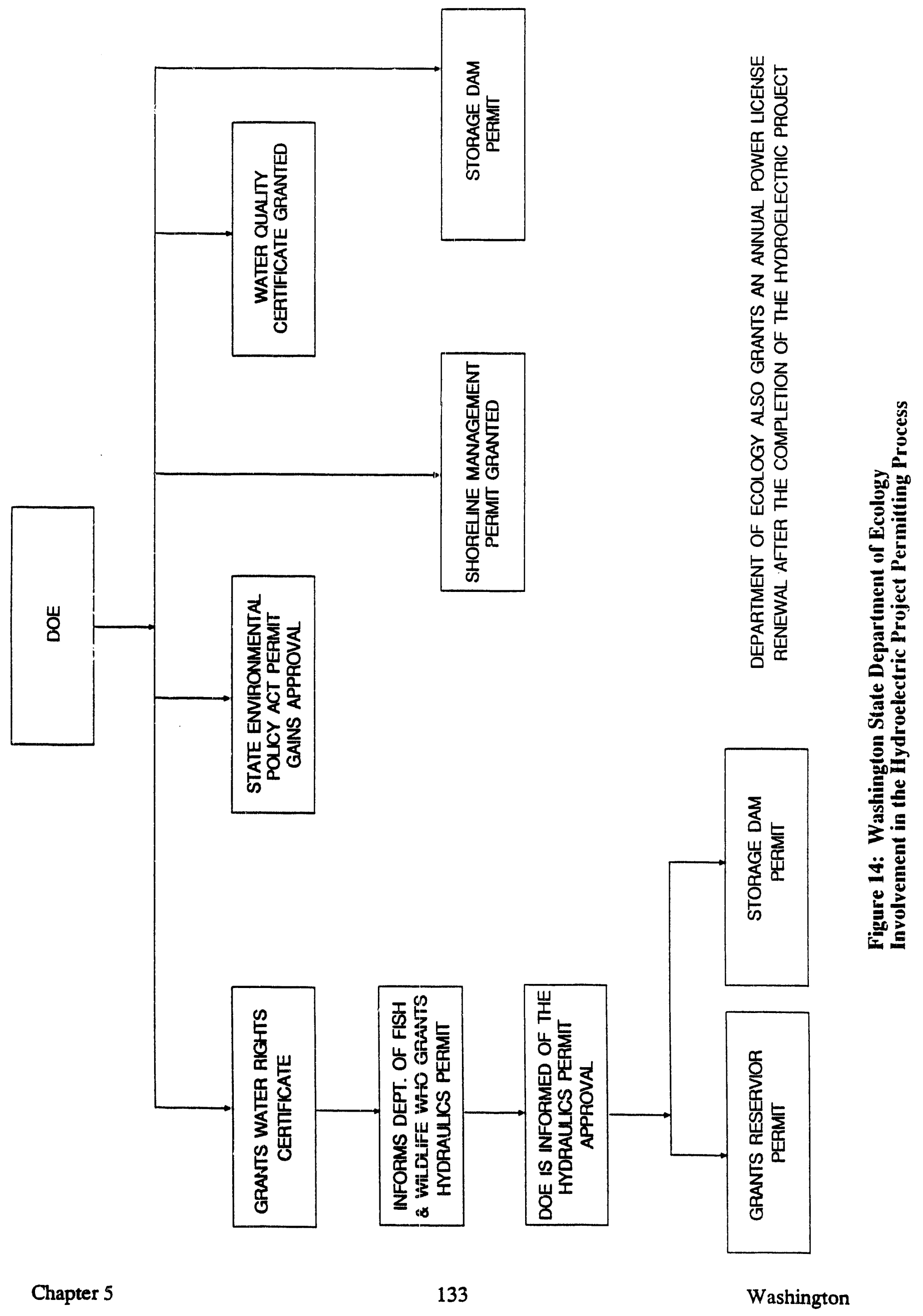


The National Pollutant Discharge Elimination System (NPDES) or State Waste Discharge Permit, Water Quality Certification and/or Short-Term Modification of Water Quality Standards, and the Wastewater Facilities Plan Approval ensure that the water quality will not be adversely affected by the project. According to WDOE, an NPDES permit is required whenever a discharge will be made into surface waters of the state.

The State Environmental Policy Act requires that proposed development in the state of Washington be evaluated to iuentify environmental impacts resulting before state and local permit decisions are made. To assist developers in obtaining information on state permits, WDOE has established the Environmental Permit Information Center (EPIC). Additional information pertaining to the EPIC will be covered in a subsequent section (see Environmental Coordination Procedure Act. chapter 90.62 RCTV).

\section{Agency: Washington Department of Fisheries (WDF) Statutory Authority: Chapter 75.08 RCW}

Under state law, the Washington Department of Fisheries (WDF) is charged to preserve, protect, perpetuate, and manage the food fish (e.g., salmon, smelt, sturgeon) and shellfish in state and offshore waters (RCW 75.08.012). To ensure WDF can carry out its responsibilities, the law requires that water diversion devices be equipped with a well-maintained fish guard (RCW 75.20.050), that instrearn flows be sufficient to support game fish and food fish populations (RCW 75.2.050), that where practical, dams and other obstructions across or in a stream be equipped with a durable and efficient fishway (RCW 75.20.060), and finally, any person desiring to conduct work $\uparrow$, will use, divert, obstruct, or change the natural flow or bed of any stream secure written $z \quad \ldots$ l from the department (Fisheries or Wildlife) having jurisdiction of the site. Complemer ary $a d$, in some cases, broader authorities are granted to the WDF under federal laws and $\mathrm{r}^{\prime}$ gulations overning development of small hydroelectric projects. Because of these respon tbilities, WDF is actively involved in consulting and conducting feasibility studies to evaluate and mitigate impacts on the fisheries' resources.

It is WDF's goal that any future hydroelectric development in the state not cause additional loss of existing or potential salmon resources or habitats. WDF strives to meet these goals by encouraging developers to: 1) conduct the necessary studies in a timely fashion for complete project evaluation; 2) locate projects in areas not presently or potentially used by salmon; 3 ) incorporate design features into the project which provides a high degree of protection for the stream habitat; and 4) operate the project in an environmentally sound manner. A properly located, designed, and operated hydroelectric facility can be brought on-line with minimal impact to the salmon resources. 


\section{Agency: Washington Department of Wildlife (WDW) \\ Statutory Authority: Chapter 77.04 RCW}

The Washington Department of Wildlife (WDW) is mandated by the legislature to ". . preserve, protect, and perpetuate wildlife. . ." of Washington (Title $77 \mathrm{RCW}$ ). These wildlife, which are property of the state, include wild animals, wild birds, and game fish. Policies set forth by the WDW state that... "The first management priority will be to establish and perpetuate the highest quality wildlife habitat."

WDW also has obligations under such federal laws as the Federal Power Act and Fish and Wildlife Coordination Act. These require developers to consult with state agencies to determine what conditions may be necessary for protection of fish and wildlife resources. The WDW commonly works together with other agencies, such as Department of Fisheries, National Marine Fisheries Service, U.S. Fish and Wildlife Service, and Indian tribes, to determine potential impacts and possible mitigation proposals.

Although each hydropower project is individually evaluated, some guiding principles are common. Replacement of losses in-kind and on-site is the objective of the Department's mitigation and compensation efforts. Although this cannot be achieved, it may be approached in several ways.

WDW works with project sponsors to ensure in advance that adequate measures to protect fish and wildlife are included in initial plans. Specific provisions are usually assumed by the project sponsor and must be incorporated into the cost/benefit analysis of the planning process.

WDW requires studies that will determine project-specific and cumulative impacts and identify mitigation and enhancement measures. On rivers where cumulative impacts are possible, delays may occur as studies are conducted. These studies are funded by project proponents, preferable under the direction and guidance of fish and wildlife agencies. WDW also advises project sponsors throughout the planning, development, and operational phases of the project.

\section{Agency: Washington Department of Natural Resources (WDNR) Statutory Authority: RCW 43.30.030}

The Washington Department of Natural Resources (WDNR) does not have an adopted, formal policy on the use of aquatic land for hydroelectric development. The following statement reflects the WDNR's position on renewable resource use as stated in the Aquatic Lands Law of 1984 and as drafted for the Aquatic Lands Policy Plan being developed within the department.

WDNR believes that renewable resource use is a public benefit. The department supports efforts to effectively use these resources provided that such uses meet social and environmental standards. The department may withhold from lease aquatic lands which it finds to have significant natural values, or may protect these values with provisions in the lease. 
RCW sections 79.01.384 and 79.01.388 allow the state to grant rights of way to municipal, private corporations, associations, or individuals for the purpose of constructing ditches, flumes, pipelines, or transmission lines for the purpose of generating or transmitting electricity. RCW 79.01.408 gives the Commissioner of Public Lands the power to grant rights to impound, hold back overflow, or inundate state lands for the purpose of constructing, operating, or maintaining a water power plant.

WDNR has established a policy regarding the awarding of right-of-way over state trust lands. The applicant is required to complete a survey of the involved land and append plats to an Application for Right-of-Way or Road Use Permit Over Lands. WDNR may charge a one-time payment for permanent development rights, which is based upon the fair market value of the land involved, or may require a base annual rental plus a percentage of gross income.

\section{Agency: Washington State Parks and Recreation Commission (WSPRC) Statutory Authority: RCW 79.72}

The Washington State Parks and Recreation Commission (WSPRC) opposes all Federal Energy Regulatory Commission issuance of preliminary permits or exemptions from licensing, and licenses for hydropower facilities affecting Washington State Parks-owned land. While WSPRC considers state parks to be "off-limits" to hydropower development, they are willing to discuss proposed projects on a site-specific basis.

\section{Agency: Washington State Energy Office (WSEO) Statutory Authority: RCW 43.21F.035}

It is the policy of the Washington State Energy Office (WSEO) to promote the development and use of a diverse array of energy resources. The use and development of renewable energy resources are particularly encouraged provided that such projects are consistent with the statutory environmental policies of the state. In order to assist in the construction of environmentally acceptable and cost-effective renewable resource projects, the state energy office has established a renewable resource section within the agency. Renewable resource specialists assist potential developers through the state and federal leasing, licensing, and permitting processes, as well as provide technical assistance in the areas of financing, design, and overall project development.

\section{Agency: Washington Office of Archaeology and Historical Preservation (WOAHP) Statutory Authority: RCW 27.34.210}

The Washington Office of Archaeology and Historical Preservation (WOAHP) is responsible for ensuring that a proposed development site is not listed in the National Register of Historic Places. If it is listed, WOAHP will determine the number and extent of any resources and their scientific or cultural importance. Accordingly, plans and procedures will be outlined for impact mitigation. 


\section{Agency: Washington Energy Facility Site Evaluation Council (WEFSEC)}

Statutory Authority: RCW 80.50.030

Washington has given its energy facility siting authority limited powers over only state and private lands. For example, in Washington the Washington Energy Facility Site Evaluation Council (WEFSEC) maintains siting jurisdiction over all lands, private and state owned, but only when on-site improvements to an existing facility with capacity in excess of over $250 \mathrm{MW}$ or more will exceed $\$ 250,000$, or a proposed generating plant will have a capacity of $250 \mathrm{MW}$ or more.

\section{Agency: Washington Utilities and Transportation Commission (WUTC) Statutory Authority: Title $80 \mathrm{RCW}$}

The general duties of the Washington State Utilities and Transportation Commission are to regulates electric companies, gas companies, irrigation companies, telecommunications companies, and water companies. Rates, services, facilities, and practices of all persons engaged in the business of supplying any utility service or commodity to the public for compensation are subject to the rules and regulations of the WUTC.

Chapter 480-107 WAC Electric Companies-Purchases of electricity from qualifying facilities and independent Power Producers and Conservation Suppliers establishes rules for determining rates, terms, and conditions governing purchases by eclectic utilities concerning: electricity from qualifying facilities; the electrical savings associated with eligible conservation measures; electricity from independent power producers; and electric utilities. The rules are intended to provide an opportunity for conservation and generating resources to compete on a fair and reasonable basis to fulfill a utility's new resource needs. It is the commission's intent that bids under these rules shall include the costs of compliance by the project with environmental laws rules, and regulations in effect at the time of the bid and those reasonably anticipated to be in effect during the term of the project.

The rules are consistent with the provisions of the Public Utility Regulatory Policies Act of 1978 (PURPA), Title II, sections 201 and 210, and regulations promulgated by the Federal Energy Regulatory Commission (FERC) in 18 C.F.R., Part 292. The rules do not preclude electric utilities from constructing electric resources, operating conservation programs, purchasing power through negotiated purchase contracts, or otherwise taking action to satisfy their public service obligations.

Electric utilities must also submit a least-cost plan to the commission as provided in WAC 480100-251. A "Least-cost plan" means a plan describing the mix of generating resources and improvements in the efficient use of electricity that will meet current and future needs at the lowest cost to the utility and its ratepayers. Each electric utility regulated by the commission has the responsibility to meet its load with a least-cost mix of generating resources and improvements in the efficient use of electricity. 
WUTC adopted formal rules with regard to bidding July 18,1989 . Washington's rules allow for all-source bidding in which QFs, IPPs, utility affiliates (with WUTC approval), and industrial and commercial conservation can participate. The bid price and the proposed pricing configuration are not subject to negotiation. Minimum bid requirements and an evaluation and ranking procedure must be a part of the utility's Request for Proposals (RFP).

\section{Environmental Permit Information Center}

The Washington Department of Ecology's (WDOE) Environmental Permit Information Center (EPIC) provides a centralized statewide environmental permit information service. EPIC can answer general questions and provide certain services during the process of obtaining state environmental permits for activities on state as well as private lands.

EPIC provides information on state environmental permits, public notice requirements, processing times, and appeal procedures as well as required federal and local permits. The agencies involved and their locations can also be identified. A Permit Application Packet, tailored to the specific needs of a project, can be assembled and sent to an applicant.

Permits may be applied for individually, or a special process may be used to obtain several environmental permits as a package. The Environmental Coordination Procedures Act (ECPA) was adopted by the Washington State Legislature in 1973 to coordinate permit procedures. This process gives an applicant the option of submitting a Master Application form to assist in identifying necessary permits for the proposed development. If this service is used, EPIC will act as the permit coordinator and assist the applicant from application through final disposition.

\section{Permit or Regulation: State Environmental Policy Act (SEPA) \\ Statutory Authority: Chapter 197-11 WAC \\ Agency: Washington Department of Ecology (WDOE)}

The Washington State Environmental Policy Act (Chapter 43.21C RCW) requires state and local agencies to evaluate proposed projects for their environmental impact before issuing any permits or other approvals. Figure 15 highlights the key steps in the SEPA process and provides references to the applicable sections of the SEPA rules (Chapter 197-11 WAC). These rules are available in a booklet from any WDOE office.

When a developer submits a permit application, the agency receiving the application determines whether or not the project is exempt from SEPA. If it is not, the agency then determines which agency requiring a permit is the "lead agency." The SEPA lead agency is responsible for complying with SEPA for a particular project. For any proposal involving a new reservoir of over 40 surface acres, the lead agency is WDOE. A public agency proposing a hydro project is the SEPA lead agency for that project. In most other cases, the lead agency will be the city or county in which the project is located. 


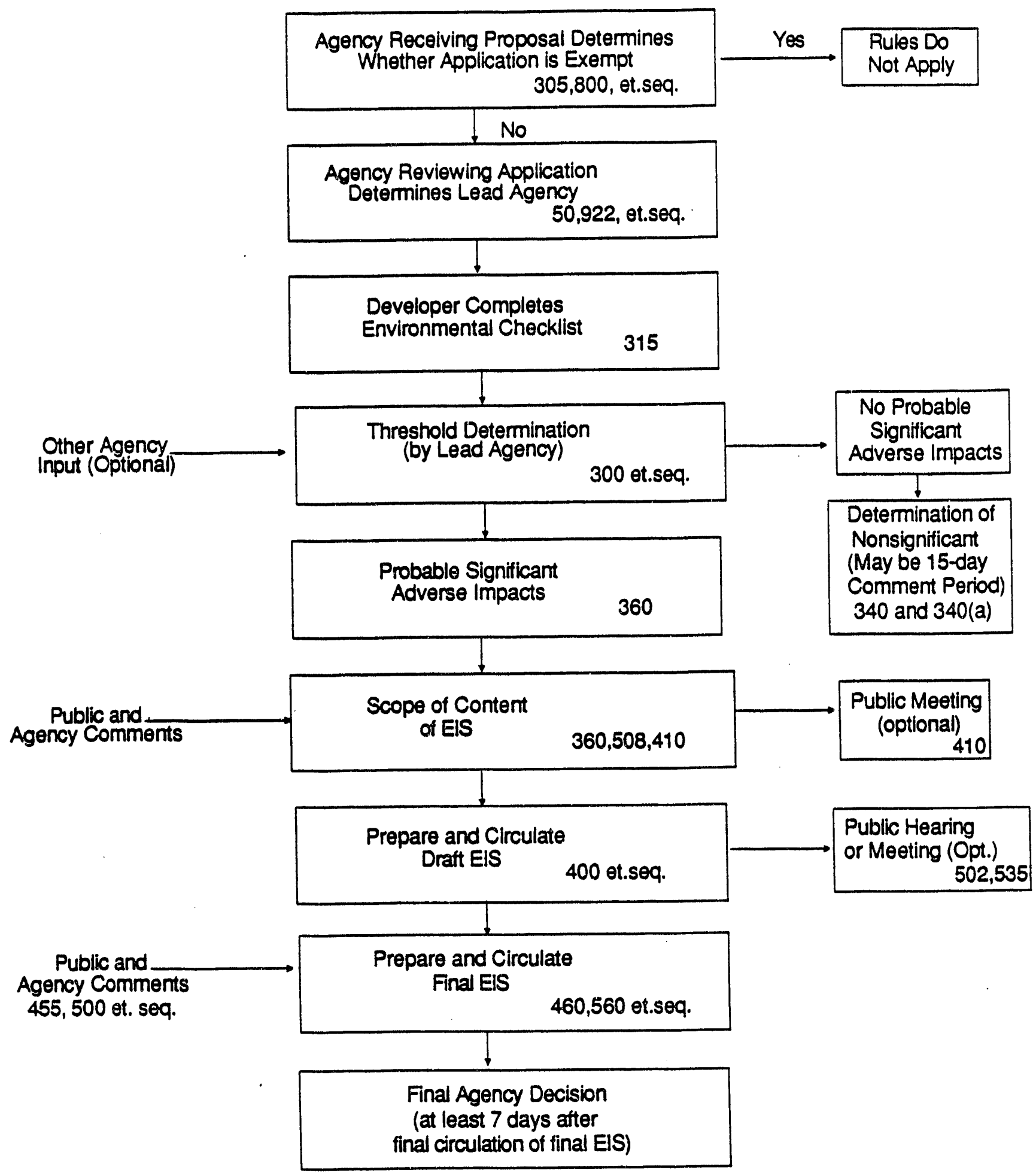

Figure 15: The SEPA Process 
When SEPA compliance is required for a project, the developer must complete an Environmental Checklist unless the developer and a lead agency agree that an environmental impact statement (EIS) will be prepared. The lead agency gives the checklist to the developer, who may complete it alone or together with the lead agency. The completed checklist provides specific information about the project, which helps the developer and the lead agency identify impacts from the project and helps the agency decide whether an EIS is required.

When the lead agency receives the completed environmental checklist, it makes the Threshold Determination to decide whether an EIS is needed. If the lead agency determines the project will not have a probable significant adverse impact on the environment, it issues a Determination of Nonsignificance (DNS) and sends it to all agencies with permits or approvals to issue, agencies whose services would be affected by the project, affected Indian tribes, and interested persons. The lead agency must also give public notice that the DNS has been issued; the method will vary among agencies. Any person or agency may submit written comments on the DNS to the lead agency within 15 days from the date of issuance. If comments are received, the lead agency must reconsider the DNS. The agency is not required to modify the DNS, but may, however, determine that there is a significant impact and require preparation of an EIS.

Whenever the lead agency determines that a significant adverse environmental impact is probable, it must prepare an EIS. The EIS provides information about a proposed project and possible alternatives to the project to agency officials, project sponsors, and interested citizens. The lead agency must use a Scoping process to narrow the contents of the EIS. During the scoping, the lead agency consults with other agencies and the public. The draft EIS focuses on: 1) the significant adverse impacts that may result from the project and its altematives, and 2) measures to mitigate or eliminate adverse impacts. The lead agency sends copies of the draft EIS to all agencies with a permit or other approval to issue, to Indian tribes that may be affected by the project, and to interested citizens. Agencies and citizens have 30 days in which to comment on the draft EIS. The lead agency must give public notice for both scoping and the draft EIS.

After considering all comments on the draft EIS, the lead agency prepares a final EIS. This document includes all comments and the lead agency's response to the comments. In addition, the draft EIS is either revised to respond to concems expressed in the comments or corrections are made to the draft EIS. The final EIS is sent to all agencies that must make decisions on permits or other approvals.

Preparation and distribution of the draft and final EIS, and public hearings generally require 3 to 6 months to complete, but this can vary substantially. Because the requirements of SEPA complement FERC's requirements for environmental analysis and disclosure, the SEPA EIS often serves as the environmental exhibit in the FERC application. In certain cases, a joint SEPA EIS/ NEPA EIS may be prepared. However, this requires close coordination with federal and state agencies. In other selected circumstances, a federal environmental assessment may be adopted by the SEPA lead agency as that agency's EIS (WAC 197-11-610). 


\section{Washington State Permitting and Licensing Requirements}

Not every hydroelectric project will require every state permit listed in Table 13. A total of 21 permit requirements are discussed in this section. Generally, large developments will require most of these, but a small facility may only need three or four of the possible permits.

Time estimates for project development given are strictly estimates. Time requirements will vary, depending on the complexity of the project and the amount of controversy involved. If several public hearings or court actions are involved in any one permit, the length of time necessary for approval will increase substantially.

\section{Water Quality/Water Use}

Washington State has what appears to be an abundant water supply. However, because of geographic and seasonal shortages; water supplies are not always adequate or available. In addition, the total water supply is finite; there will never be more. Because Washington's population is increasing, there is an expanded water demand for domestic, industrial, agricultural, recreational purposes, as well as power generation. The permits listed below are part of Washington's water resource management strategy.

It is Washington State's policy to "...maintain the highest possible standards to ensure the purity of all waters of the state consistent with public health and public enjoymexit...the propagation and protection of wildlife, birds, game, fish and other aquatic life, and the industrial development of the state."

There are many aspects of hydropower developments that have the potential to impact water availability or water quality. Detrimental impacts can frequently be minimized or eliminated if appropriate project design criteria or mitigation methods are applied. During the permitting process, agency experts will ensure that the project is designed so that instream resource values are protected.

\section{Permit or Regulation: Water Right}

Statutory Authority: Chapters 18.104, 43.27A, 90.03, 90.14, 90.16, 90.22, 90.44

and 90.54 RCW; Chapters 173-100, 173-136, 173-50, 173-154, 173-166, 173-500, and 173-590 WAC

\section{Agency: Washington Department of Ecology (WDOE)}

Information required for this permit application includes: a section map, the source of the water supply, how the water will be used, the exact location of the point of diversion or withdrawal, a legal description of the property on which the water is to be used, the signature of the legal landowner, and a description of the proposed water system. This application should be submitted as early as possible to establish a priority date, the nature and amount of proposed use, date construction will be completed, and the date of complete application of water to beneficial use. The 
process involved in granting a water rights certificate is shown in Figure 16. Processing begins when an application is received by the Washington Department of Ecology (WDOE). SEPA compliance is required before issuance of this permit.

Individuals or corporations may exercise the right of eminent domain to acquire water rights or property necessary for water conveyance (see RCW 90.03 or 90.16). As provided for by $\mathrm{RCW}$ 90.16 , any entity claiming the right to use water for power production must pay an annual fee to the state.

\section{Permit or Regulation: Reservoir Permit and Dam Safety Approval}

Statutory Authority: RCW 90.03.370, 90.03.350, and WAC 508- 12260

Agency: Washington Department of Ecology (WDOE)

The application for a Reservoir Permit requires information on the source, use, and capacity of the reservoir, the location of the point of diversion or withdrawal, the location and construction of impounding structures, and a legal description of the location of the structure. Generally, before a Reservoir Permit is granted, the applicant must obtain approval of the construction plans and specifications of the dam and related structures. Also, there will be follow-up inspections during construction and periodically thereafter to ensure that the project is maintained in a safe condition. The Storage Dam Construction and Reservoir Operating Permit processes are given in Figure 17. SEPA compliance is required prior to issuance of this permit.

\section{Permit or Regulation: Water Quality Certification and Modification}

Statutory Authority: Section 401, Federal Clean Water Act;

Chapter 173-225 WAC/RCW 90.48.120; WAC 173-201-035(8e)

Agency: Washington Department of Ecology (WDOE)

Water Quality Certification is a statement issued by the Washington Department of Ecology (WDOE) that the proposed activity will comply with applicable water quality standards and discharge limitations. The certification is required by federal law as a prerequisite to obtaining a FERC license or exemption. Issuance of a certification is exempt from SEPA requirements.

Because most new hydropower construction activities will unavoidably violate state water quality criteria on a short-term basis particularly the turbidity criterion, such projects will require a Short-term Modification of Water Quality Criteria. A modification may be required before WDOE can issue a Water Quality Certification. SEPA compliance is required for a modification. 


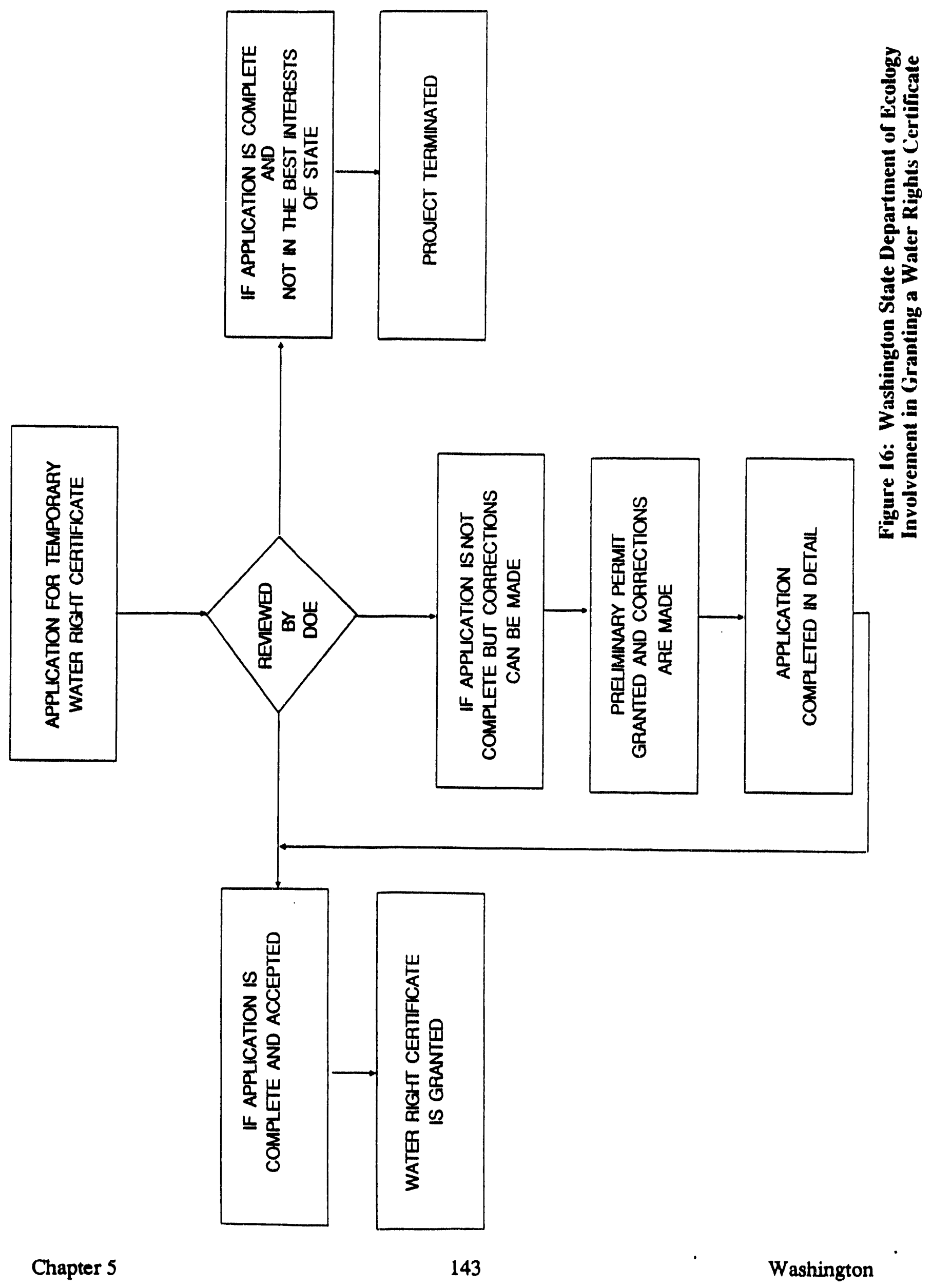




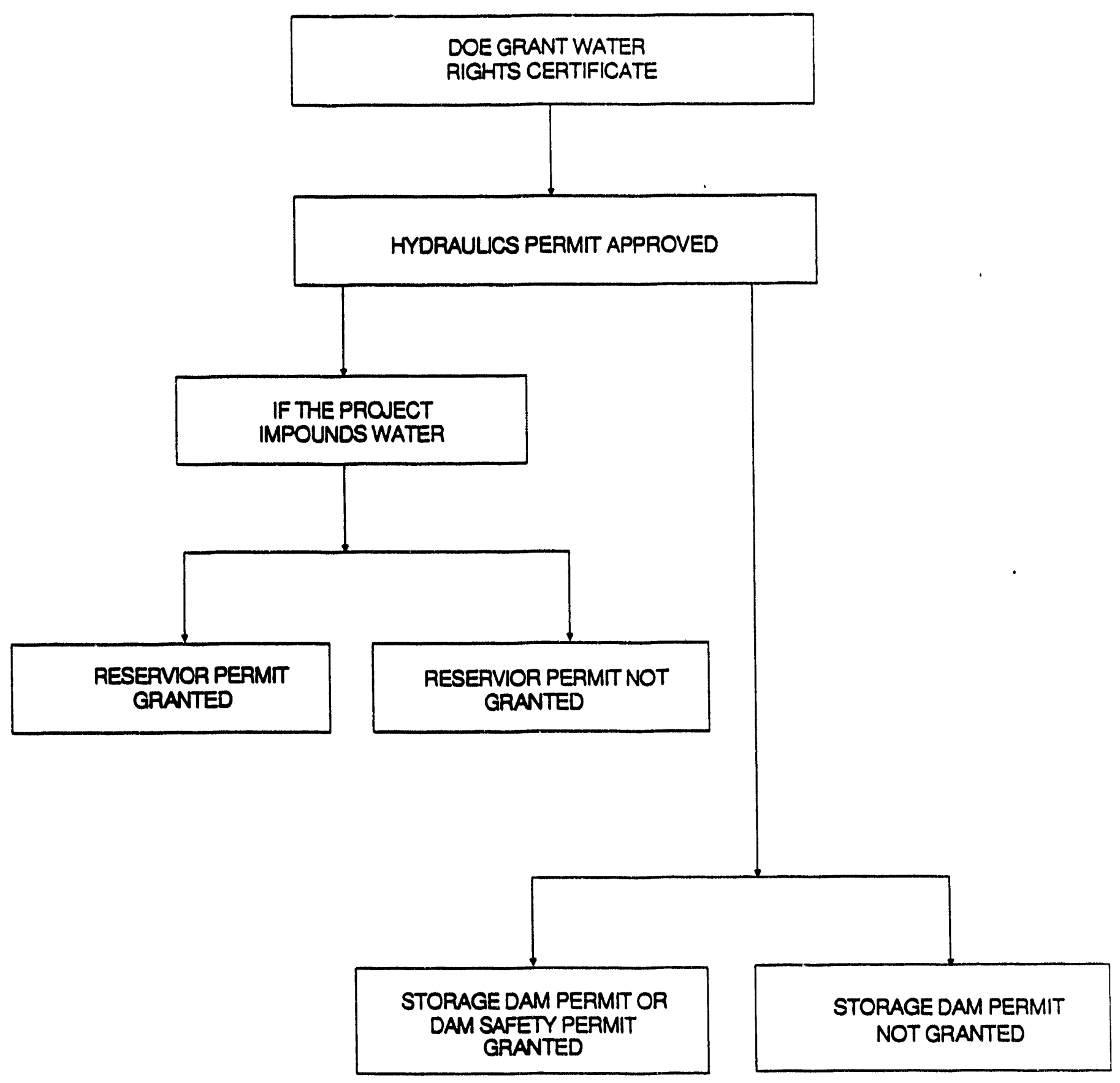

Figure 17: The Storage Dam Construction and Reservoir Operating Permit Process 


\section{Table 13}

Possible State Permits or Evaluations Required for Development of a Hydroelectric Project in Washington

\begin{tabular}{|c|c|c|c|c|}
\hline Permit & Agency & Comments & Fees & $\begin{array}{l}\text { Approx. } \\
\text { Time }\end{array}$ \\
\hline $\begin{array}{l}\text { State Environmental } \\
\text { Policy Act Compliance }\end{array}$ & $\begin{array}{l}\text { SEPA lead } \\
\text { agency }\end{array}$ & & None & $\begin{array}{l}3 \text { wks.- } \\
3 \text { vTs. }\end{array}$ \\
\hline $\begin{array}{l}\text { Permit to Appropriate } \\
\text { Public Waters }\end{array}$ & WDOE & $\begin{array}{l}\text { Required for any use of water for hydro- } \\
\text { power generation. Permit must be obtained } \\
\text { pritor to construction. In some cases an ex- } \\
\text { isting right may be changed to hydropower } \\
\text { ues upon approval by wDOE. }\end{array}$ & $\begin{array}{l}\text { Examination fees: } \$ 10 \\
\text { or for each cfs appropriated: } \\
1-500-\$ 2 / \mathrm{cfs} \text {. } \\
500-2,000-50 / \mathrm{cfs} \text {. } \\
2,000+-20 \mathrm{~d} / \mathrm{cfs} \text {. } \\
\text { Other fees also apply. }\end{array}$ & $\min ., 3+\operatorname{mos}$ \\
\hline $\begin{array}{l}\text { Reservoir Purmit and } \\
\text { Dam Safoty Approval } \\
\end{array}$ & WDOE & $\begin{array}{l}\text { For my man-mede rescrvoir with a vol- } \\
\text { ume of } 10 \text { acre-feet or } 10 \text { feet in depth }\end{array}$ & $\begin{array}{l}\text { S10 or cost, which } \\
\text { ever is greater }\end{array}$ & $2+$ mos. \\
\hline Water Quality Certification & WDOE & Required before a FERC license is issued. & None & 2 mos.- $1 \mathrm{yr}$. \\
\hline $\begin{array}{l}\text { Short-Torm Modification to } \\
\text { Wacer Quality Standards }\end{array}$ & WDOE & $\begin{array}{l}\text { Required for any activity that will resule in } \\
\text { temporary violation of state water quality } \\
\text { standards (chapter } 173-201 \text { WAC). }\end{array}$ & None & 2 mos. \\
\hline Flood Control Zone Permit & WDOE & $\begin{array}{l}\text { Required if project is located in desig- } \\
\text { nated flood control zone. }\end{array}$ & None & 1 no. \\
\hline $\begin{array}{l}\text { NPDES and/or State } \\
\text { Waste Diacharge Permit }\end{array}$ & WDOE & $\begin{array}{l}\text { Needed if pollutants will be dis. } \\
\text { charged into surface or ground waters }\end{array}$ & $\begin{array}{l}\text { None } \\
\text { mos. }\end{array}$ & $2-6$ \\
\hline $\begin{array}{l}\text { Sewage and Induatrial Waste } \\
\text { Treatment Approval }\end{array}$ & WDOE & $\begin{array}{l}\text { May be required if project includes } \\
\text { sewage treatment or disposal system. }\end{array}$ & None & 2 mos. \\
\hline $\begin{array}{l}\text { Annual Power Production } \\
\text { License Fee }\end{array}$ & WDOE & $\begin{array}{l}\text { Assessed at the beginning of every year. } \\
\text { Based on theoretical horsepower } \\
<S O \text { hp exempt }\end{array}$ & $\begin{array}{l}0-50 \text { hp - exempt } \\
\text { s0-1,000-10e/hp } \\
+1,000-10,000-2 \notin / \mathrm{hp} \\
+10,000+-1 \notin / \mathrm{hp}\end{array}$ & \\
\hline $\begin{array}{l}\text { Hydraulic Project } \\
\text { Approval }\end{array}$ & $\begin{array}{l}\text { WWDF or } \\
\text { WDW }\end{array}$ & $\begin{array}{l}\text { Required for any construction affect- } \\
\text { ing surface waters or stream beds. }\end{array}$ & None & 45 days \\
\hline $\begin{array}{l}\text { Public Water Supply } \\
\text { Approval }\end{array}$ & DSHS & $\begin{array}{l}\text { Required if public drinking water } \\
\text { supply is needed or altered }\end{array}$ & $\begin{array}{l}\text { Based on size of } \\
\text { proposed system }\end{array}$ & 3 mos. \\
\hline Archacological Approval & WOAHP & Contact prior to surveys required by FERC & No set standand & 2 mos. \\
\hline $\begin{array}{l}\text { Forest Practices Application } \\
\text { Notification }\end{array}$ & WDNR & $\begin{array}{l}\text { For construction on forested, non- } \\
\text { federal land }\end{array}$ & None & $\begin{array}{l}5-30 \\
\text { days }\end{array}$ \\
\hline Surface Mining Permil & WDNR & $\begin{array}{l}\text { Operations disturbing } 2 \text { acres or } \\
10,000 \text { tons or greater of surfece } \\
\text { material on nonfederal land }\end{array}$ & $\$ 250$ & $\begin{array}{l}2.3 \\
\text { mos. }\end{array}$ \\
\hline Buming Pormit & WDNR & To burn wood and dabris & None & 1 week \\
\hline Dumping Permit & WDNR & $\begin{array}{l}\text { Dumping } 750 \mathrm{cu} \text { yds. of land clearing } \\
\text { debris on nonfederal land. }\end{array}$ & None & 1 week \\
\hline Exement to Use State Lands & WDNR & Facilities, transmianion lines on state lands. & Fair market value & 4 mos. \\
\hline RIghtof-Way or Road Use & WDNR & For essements to croses state lands & 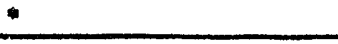 & $2+$ mos. \\
\hline $\begin{array}{l}\text { Application to Purchese } \\
\text { Valuable Macerial } \\
\end{array}$ & WDNR & $\begin{array}{l}\text { Covers excavation and use of any stone, rock } \\
\text { sand, gravel, or silt from state lands. }\end{array}$ & Fair market value & $2+$ mos. \\
\hline $\begin{array}{l}\text { Permit to Temporarily Remove } \\
\text { or Destroy Survey Monument }\end{array}$ & WDNR & $\begin{array}{l}\text { Removal or deatruction of any section cor- } \\
\text { ner or other land boundary mark or monument. }\end{array}$ & None & I week \\
\hline $\begin{array}{l}\text { Special Motor Vehicle } \\
\text { Permit }\end{array}$ & DOT & $\begin{array}{l}\text { For any overweight or oversized } \\
\text { vehicle. }\end{array}$ & None & I day \\
\hline $\begin{array}{l}\text { New Source Construction } \\
\text { Approval }\end{array}$ & $\begin{array}{l}\text { Local Air } \\
\text { Pollution } \\
\text { Control } \\
\text { Authority or } \\
\text { WDOE for } \\
\text { certuin } \\
\text { counties }\end{array}$ & $\begin{array}{l}\text { For duat control during use of coo- } \\
\text { struction machines such as concrete } \\
\text { batch plants and asphalt }\end{array}$ & $\begin{array}{l}\text { Varies with } \\
\text { individual air authorities }\end{array}$ & $\begin{array}{l}1.2 \\
\text { mos. }\end{array}$ \\
\hline
\end{tabular}

NOTE: Moat projects will not require all of the permits listed. Small projects are likely to require only a few of those permits.

- See additional information on the individual permit.

KEY: cf - cubic feet per second hp - horsepower 
To request a certification and/or modification, a letter should be sent to WDOE containing description of the project, including location and proposed activities or the nature of any water quality violations expected, including specific criteria that will be violated, the scheduled duration, and extent of these occurrences; and a description of methods proposed to minimize the impact on water quality. Depending on the project, a review of plans and specifications may also be required.

The Water Quali.y Certificate process is shown in Figure 18. State permits may be applied for prior to SEPA compliances, however, most permits require SEPA compliance before issuance.

\section{Permit or Regulation: Flood Control Zone Permit}

Statutory Authority: RCW 86.16.080

Agency: Washington Department of Ecology (WDOE)

This permit is required for the construction of any new structure, or the reconstruction or modification of an existing structure within designated flood control zones. Permit applications should include plans showing dimensions and elevations of planned obstructions and provisions for water passage through, around, and over works. Known high water marks and dates should also be included. The Flood Control Zone Variance process is indicated in Figure 19.

The counties of King, Cowlitz, Skagit, Kittitas, Clallam, Thurston, and Clark administer the flood control zone permit systems within their county boundaries. In these counties, apply for permits through the local building or planning department; otherwise, contact the nearest WDOE Regional Office. This permit may require SEPA compliance.

\section{Permit or Regulation: National Pollutant Discharge Elimination System (NPDES) State Waste Discharge Permit}

Statutory Authority: Chapter 173-220 or 173-216 WAC Agency: Washington Department of Ecology (WDOE)

The application requires information on waste source flow and expected characteristics, disposal method, water supply, wastewater disposal, water supply volumes, water utilization, planned improvements, storm water treatment, plant operation, materials and chemicals used, and production. Prior SEPA compliance is required.

\section{Permit or Regulation: Wastewater Facilities Plan Approval Statutory Authority: $R C W$ 90.48.110 and Ch. 173-240 WAC Agency: Washington Department of Ecology (WDOE)}

Engineering reports, plans, and specifications for construction of new sewage or industrial waste treatment or disposal systems, including systems for erosion/sedimentation control, disposal of wastewater from concrete batching and coring, etc., must be submitted for review and approval by the Washington Deparment of Ecology (WDOE). Prior SEPA compliance is required. 


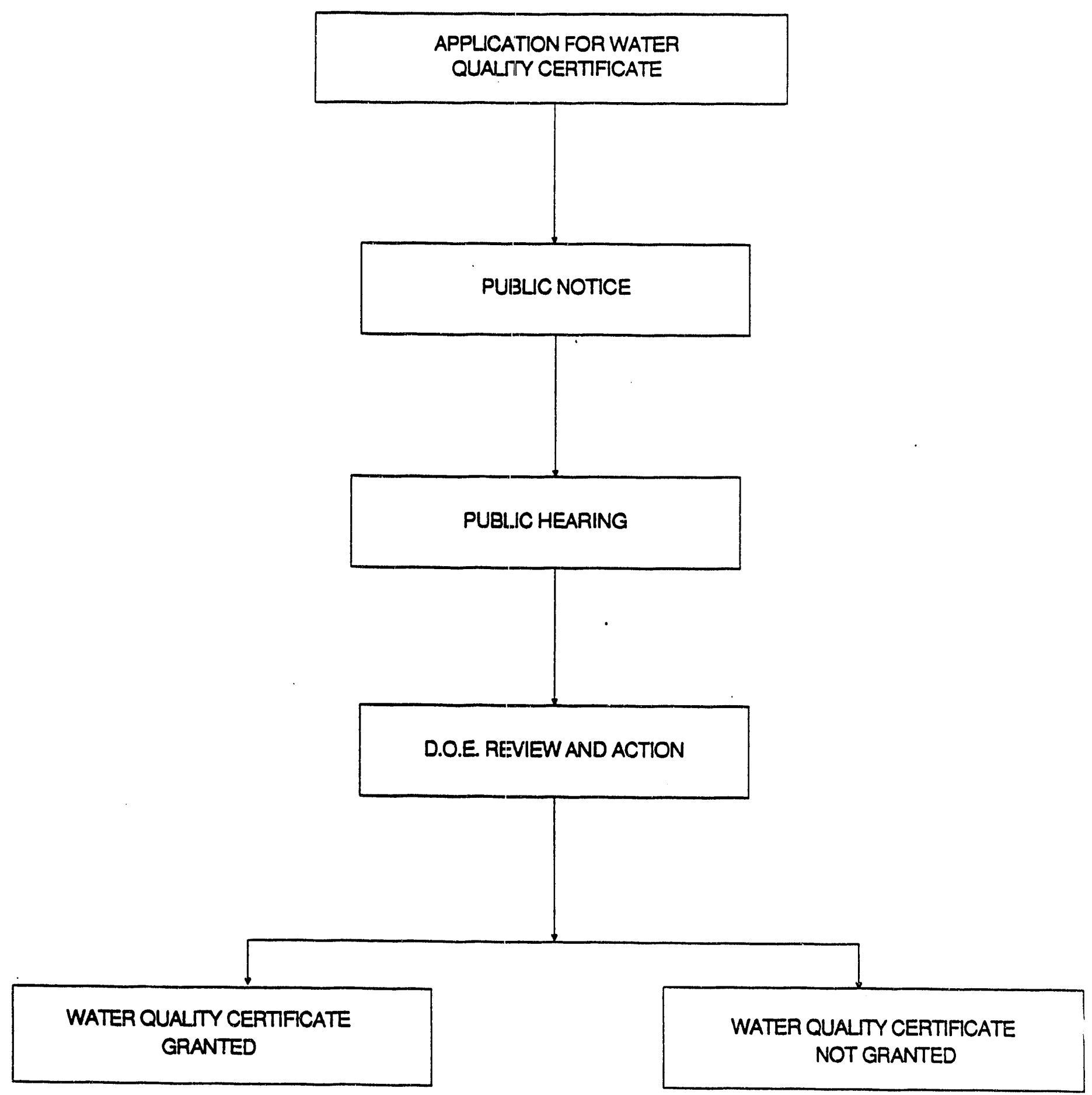

Figure 18: The Water Quality Certification Process

(Wrashington) 


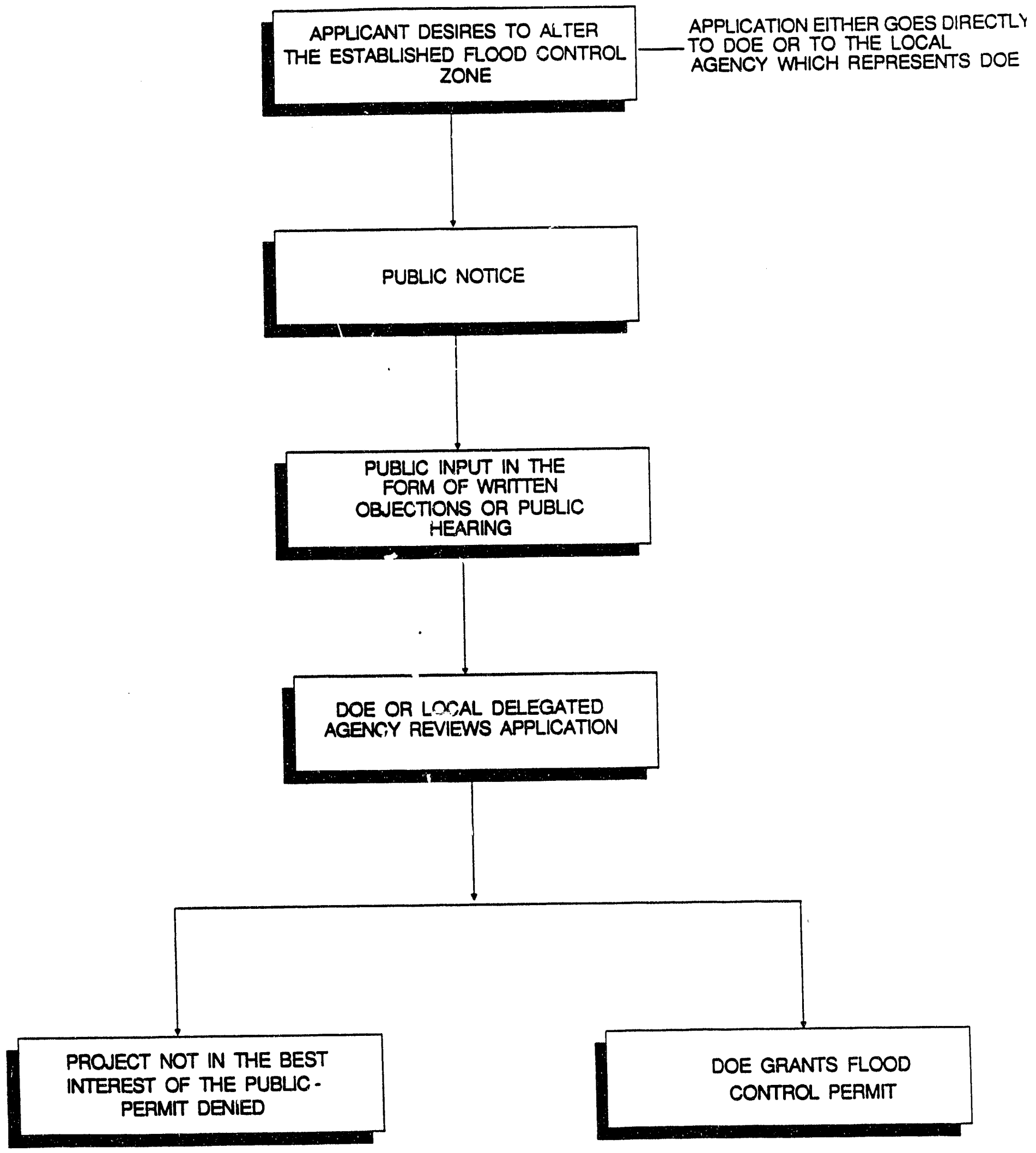

Figure 19: The Flood Control Zone Variance Process

(Washington) 


\section{Permit or Regulation: Power License Fee}

Statutory Authority: RCW 90.16.050

\section{Agency: Washington Department of Ecology (WDOE)}

Whenever a water right permit is issued authorizing generation of power in excess of 50 theoretical horsepower (approximately $37.3 \mathrm{~kW}$ ), the applicant is required to pay an annual fee based on the water used. For undeveloped projects where a water right permit has been issued, the fee is one-half of the full fee. As an example, the annual fee for a developed $10 \mathrm{MW}(13,410$ theoretical HP) plant would be $\$ 314.10$.

\section{Permit or Regulation: Hydraulic Project Approval}

Statutory Authority: RCW 75.20.100

Agency: Washington Departments of Fisheries and Wildlife (WDF and WDW)

The application for this permit requires information on construction schedule, activities, methods, impact mitigation, total project cost, equipment, and duration of activities in and around streams and lakes. Information is also needed on any proposed changes in the channel bed or configuration, alterations of the stream bank vegetation, legal descriptions of water outlet locations, water quality impacts, restoration methods for vegetation and stream channel, fish passage and protection, and siltation and erosion controls. The Hydroelectric Project Approval Process is shown in Figure 20. Prior SEPA compliance is required.

\section{Permit or Regulation: Public Water Supply Approval}

Statutory Authority: Chapter 248-54 WAC

Agency: Washington Department of Social and Health Services (WDSHS)

This approval is given in two parts. First is a preliminary design review that takes 60 days followed by a final plans and specifications review that takes 30 days. See WAC 248-54, sections 085 and 095 for details. After construction is complete, there will be a final review of the approved plans and the as-built drawings to see if there are any significant changes. Ultimate approval is subject to SEPA compliance. The preliminary design should be turned in as soon as possible, and the final plans should be submitted shortly before SEPA compliance to allow for review time.

\section{Land Use}

The Washington Department of Natural Resources (WDNR), under the direction of the Commissioner of Public Lands, administers many permits regulating the use of over 12.5 million acres of state and private land. Forest practices enforcement, surface mine regulation, and administration of other land resource permits are among the WDNR's responsibilities. The Washington Department of Community Development and the Washington Office or Archaeology and Historic Prevention are charged with protecting historic and archaeological resources in the state. 


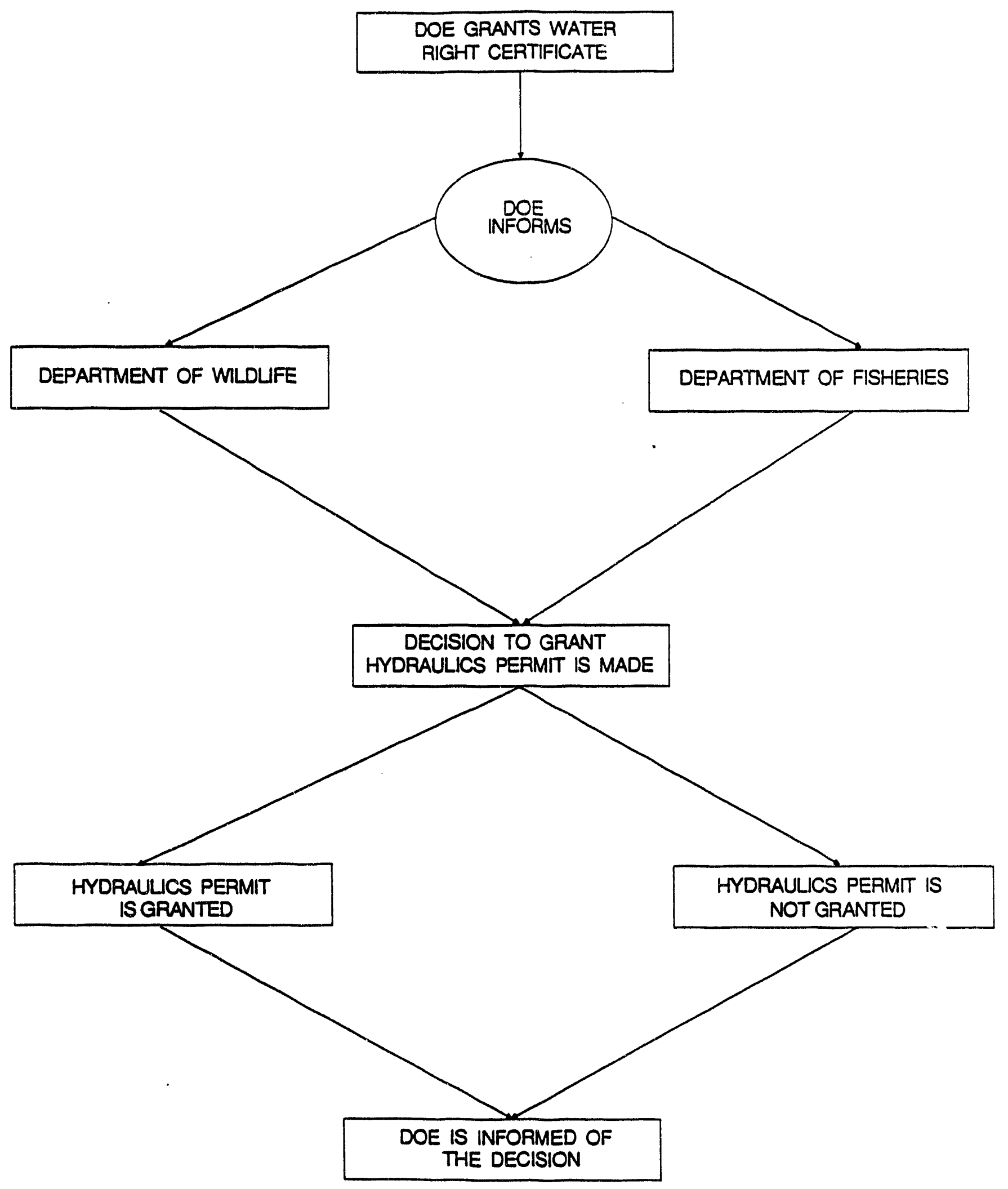

Figure 20: The Hydraulic Project Approval Process

(Washington) 
Permit or Regulation: Forest Practices

Statutory Authority: RCW 76.09.060

Agency: Washington Department of Natural Resources (WDNR)

Information is required on the location of the construction activities, the location of borrow and disposal areas, the construction methods and equipment, the size of needed rights-of-way, the restoration plans, the drainage plans, and an evaluation of the wildlife habitat to be removed.

Depending on the class of forest practice involved (see WAC 222-16-050), this permit may be contingent on the granting of Hydraulic Project Approval, Shoreline Substantial Development permit, Water Quality Certification, and SEPA compliance. Hydraulic approvals and must be renewed yearly.

\section{Permit or Regulation: Surface Mining Permit}

Statutory Authority: $R C W$ 78.44.080

Agency: Washington Department of Natural Resources (WDNR)

A bond may be required for reclamation activities before this permit is granted. Engineering information required includes togographic maps, disposal and borrow site locations, construction methods, equipment, mitigation plans for runoff and erosion, and the proposed schedule.

Environmental information includes soil characterization, erosion control measures, reclamation and revegetation plans, and methods to protect surface water quality. The status of other state and local permits should also be given. SEPA compliance is required prior to issuance.

\section{Permit or Regulation: Right-of-Way or Road Use}

Statutory Authority: RCW 79.01.384 and 79.01.388

Agency: Washington Department of Natural Resources (WDNR)

Applications for the right to use state lands are available at the Washington Department of Natural Resources (WDNR) headquarters or the local regional office. A separate application must be filed for each easement. The fair market value of any timber cut will be assessed, and any costs incurred for a timber sale will be charged to the applicant.

Plans and sketches showing the location and design of all new construction must be submitted. Also needed are the locations, on plats, of new construction, a description of the engineering involved, and a description of the environment impacts. SEPA compliance is required prior to issuance. 
Permit or Regulation: Application to Purchase Valuable Material

Statutory Authority: $R C W$ 79.01.124 and 79.01.132

Agency: Washington Department of Natural Resources (WDNR)

A standard application form can be obtained from the Washington Department of Natural

Resources (WDNR). WDNR will evaluate the fair market value for a purchase price. The legal location of the pit or quarry, excavation method proposed, location of any timber stands or state quarries, proposed excavation time, planned use of the material, and reclamation plan should also be provided with the application. SEPA compliance is required prior to issuance.

Permit or Regulation: Permit to Temporarily Remove or Destroy Survey Monument Statutory Authority: Chapter 332-120 WAC

Agency: Washington Department of Natural Resources (WDNR)

This permit is issued by the Washington Department of Natural Resources (WDNR) subject to the provisions of Chapter 332-120 WAC, which re-quires adequate referencing and replacement of the monument or reference monuments after the development has been completed. A description of existing conditions and reason for removal are required. Coordination with the Washington Coordinate System may be required.

Permit or Regulation: Archaeological Excavation

Statutory Authority: Chapters 27.44 and 27.53 RCW; Chapter 25-48 WAC

Agency: Washington Department of Community Development (WDCD), Washington Office of Archaeology and Historic Preservation (WOAHP)

The Washington Department of Community Development (WDCD), Washington Office of Archaeology and Historic Preservation (WOAHP) should be contacted prior to the start of the project to determine if historic or archaeological sites will be affected. A historic/archaeological excavation assessment may be required. A permit from WDCD, WOAHP, must be obtained prior to any excavation that will alter or remove Native Indian grave site or archaeological resources.

The status of any sites or structures listed in or eligible for the State or National Register of Historic Places or Local Landmark designation may need to be determined. Plans for protection of mitigation measures may be a condition of any permit issued.

Permit or Regulation: Archaeological Approval

Statutory Authority: Executive Order 11593

Agency: Washington Office of Archaeology and Historic Preservation (WOAHP)

The Washington Office of Archaeology and Historic Preservation (WOAHP) should be contacted prior to the start of a project. A historic/archaeological assessment may be required at the project site. The status of any sites or structures that are listed for the National Register of his- 
toric places will be identified. The number and extent of any resources that are present and their scientific importance will be determined. Plans and procedures will be outlined for recovery or mitigation of adverse effects. This approval is required prior to obtaining federal permits or licenses and SEPA approval.

\section{Permit or Regulation: Competitive Bidding}

Statutory Authority: Chapter 480-107 WAC

Agency: Washington Utilities and Transportation Commission (WUTC)

Competitive bidding refers to a process whereby many sellers compete with each other to market energy services to a regulated electric utility. Energy services may be provided by either supplyside resources (generating facilities) or demand-side resources (conservation and load management). Bidding should be viewed as one of many pathways the utility may follow to achieve the least-cost planning goal of acquiring the resource mix with the best combination of expected costs and variance of costs.

This regulation establishes the rules for determining rates, terms, and conditions governing the following purchases by electric utilities: electricity from qualifying facilities, the electrical savings associated with eligible conservation measures, electricity from independent power producers, and, at the utility's election, utility subsidiaries and the electric utilities. The rules are intended to provide an opportunity for conservation and generating resources to compete on a fair and reasonable basis to fulfill a utility's new resource needs.

\section{Construction}

\section{Permit or Regulation: Special Motor Vehicle Permit}

Statutory Authority: $R C W$ 46.44.090

Agency: Washington Department of Transportation (WDOT)

This permit may be issued at the time of application. Information on tire size, number of tires, the weight and size of the vehicle, and the current registration must be supplied. The permit may be applied for by the contractor or by the developer.

\section{Permit or Regulation: Burning Permit \\ Statutory Authority: $R C W$ 76.04.150 \\ Agency: Washington Department of Natural Resources (WDNR)}

This permit should be applied for after construction, when the contractor has piled all debris for burning, and fulfilled all safety precautions. An inspector will be sent to examine the site. If it is safe, a permit will be issued at the site. 
Permit or Regulation: Dumping Permit

Statutory Authority: RCW 76.04.242

Agency: Washington Department of Natural Resources (WDNR)

After a dumping area has been established, the Washington Department of Natural Resources (WDNR) is contacted and an inspector sent. The permit will be issued at the site. The inspector should be provided with a description of the dumping location and information regarding dumping practices and fire safety precautions.

\section{Safety and Health}

This section deals with regulations designed to protect public health and safety. Included are a number of permits dealing with hazardous, dangerous, and solid waste. The Washington Department of Ecology (WDOE) has several programs devoted to managing waste to protect public health and the environment.

Permit or Regulation: On-Site Sewage Disposal

Statutory Authority: Chapter 90.48 RCW; Chapter 173-240 WAC Agency: Washington Department of Ecology (WDOE) and Washington Department of Social and Health Services (WDSHS) or Local Health Department

Businesses and residences that locate outside areas served by sewer systems frequently treat and dispose of sewage on the property where it originates through septic tanks and subsurface disposal fields. These systems are reviewed and approved by local health departments, the Washington Department of Social and Health Services (WDSHS), or the Washington Department of Ecology (WDOE) depending on the size and nature of the system.

Local health departments issue permits for on-site sewage with design flows, at any common point, less than 3,500 gallons/day.

WDSHS reviews and approves plans and specifications for on-site sewage systems with design flows, at any common point, between 3,500 gallons/day and 14;500 gallons/day. Local health departments can take on this responsibility with a contractual agreement with WDSHS.

WDOE reviews and approves plans and specifications for on-site systems exceeding 14,500 gallons/day, all systems receiving state or federal construction grants under the Clean Water Act and systems using mechanical treatment or lagoons with ultimate design flows above 3,500 gallons/day. WDOE regulations generally require public ownership, operation, and maintenance of domestic waste water facilities. 
Permit or Regulation: Sewage Holding Tank Variance

Statutory Authority: Chapter 248-96 WAC revised (6/92); Chapter 246-272 WAC

Agency: Washington Department of Social and Health Services (WDSHS);

Local Health Department

An application for this permit can be obtained from the local Health Department. The following should be included with the application: a drawing of the proposed facility including location and size; information on maintenance schedules; precautions to be taken against overflow; and a signed contract with a holding tank pumping firm that indicates a servicing schedule and a backup pumping firm.

Permit or Regulation: Stute Waste Discharge Permit Statutory Authority: Chapters 90.48, 90.52, 90.54 RCW; Chapters 173-216 and -224 WAC Agency: Washington Department of Ecology (WDOE)

Through these permits, the Washington Department of Ecology (WDOE) regulates the discharges or disposal of industrial, commercial, or municipal waste material into the state's groundwaters, and the discharge of industrial or commercial wastes into municipal sewer systems.

The permit application requires information on water supply volume, water utilization, wastewater flow, characteristics and disposal methods, planned improvements, storm water treatment, plant operation, materials and chemicals used, production, and other relevant information. WDOE generally requires public ownership, operation, and maintenance of domestic wastewater facilities.

Approximate Time Required to Obtain Permit This permit should take 2 to 6 months to obtain.

Permit or Regulation: Identification Number/Reporting Requirements (Hazardous Waste) Statutory Authority: RCW 70.105; Chapter 173-303 WAC Agency: Washington Department of Ecology (WDOE)

An EPA/State identification number is required for persons who generate, transport, or offer for transport hazardous wastes going to a storage, treatment, and/or a disposal facility.

An annual reporting of hazardous waste management activities is required of the owner or operator of a facility that has an active EPA/State identification number. 
Permit or Regulation: Hazardous/Dangerous/Solid Waste

Statutory Authority: Chapter 70.105 RCW; Chapter 173-303 WAC

Agency: Washington Department of Ecology (WDOE)

The Washington Department of Ecology (WDOE) is responsible for identifying, investigating, and cleaning up hazardous waste sites. Any contaminated site must be reported, by the facilities ' owner or operator, to WDOE. Facilities found contaminated and that require remedial action are placed on a hazardous waste site list maintained by WDOE. Contaminated sites must be cleaned up in accordance with state standards. Cleanups may be done independently (without WDOE oversight or approval); however, all cleanups must be reported to WDOE and are subject to later review. For this reason, owners and operators are encouraged to contact WDOE to develop an approvable testing and cleanup plan.

Permit or Regulation: Hazardous Waste Release Notification

Statutory Authority: Chapter 70.105 RCW; Chapter 173-303 WAC

Agency: Washington Department of Ecology (WDOE)

Prompt notification to the Washington Department of Ecology (WDOE) is required when spills or releases of hazardous substances occur that have the potential to impact human health or the environment. Responsibility for reporting spills lies with the person who spills or releases the substance; however, any person aware of such spills is encouraged to contact WDOE.

Permit or Regulation: Underground Storage Tank Notification Requirement Statutory Authority: 40 CFR 280.22; Chapter $90.76 \mathrm{RCW}$

Agency: Washington Department of Ecology (WDOE)

If developer has installed or intends to install an underground storage tank (UST), a state UST notification form must be completed. This form is available from the Washington Department of Ecology (WDOE). WDOE administers a federal requirement to report regulated underground storage tanks and information about these tanks.

Currently, under federal requirements, notification is required within 30 days of putting into service a new tank.

\section{Local Permitting and Licensing Requirements}

Local govemments such as cities, counties, road districts, flood control districts, and drainage districts will have some jurisdiction over hydroelectric project development in nearly all cases. Most county governments require building permits for construction and entail building code, electrical code, and plumbing code compliance. Counties also have planning and zoning commissions that will review project plans for compliance with comprehensive plans, zoning regulations, and needs for conditional or special use permits. Counties may also have some jurisdiction 
over construction in or near defined flood plains and over use of, or construction near, county highways. The county courthouse, the county zoning administrator, and the county highway district are the best contacts for determining what permits or approvals will be required.

If a proposed site is within a city's limits or within its area-of-impact, appropriate contact should be made with city officials regarding building permits, zoning regulations, flood plain construction, and highway usage. Contact the city hall of the nearest city for a determination of the required permits and approvals and jurisdiction.

Smaller communities often issue all permits through a single office, such as the Clerk. In some counties, one or more highway districts exist that are responsible for construction and inaintenance of roads. These agencies will be the administrators of all permits/approvals having to do with public rights-of-way.

A number of these permits, mainly those administered by the local planning department, will involve substantial discretionary action on the part of the decision makers, approval being based on conformance of plans with established criteria or standards. Therefore, these decisions will usually be made by elected or appointed officials (city councilmen, county commissioners, or planning and zoning commissioners). Another group of approvals will be based on the adequacy of technical plans. These will generally be the permits listed as being administered by the public works department and building department. Several items. will be simply a matter of registration, including the business license and registration of proprietorship. The following is a general description of each of the permits and approvals which may be required.

Within the framework of federal and state regulation, local governments perform duties which can have unique and significant impacts on energy project development. Local governments can set an example by financing and developing energy facilities themselves. They can encourage private development through information distribution and active recruiting of facilities. Cities and counties also regulate energy facilities. Below state-level citing thresholds, the jurisdictions are the primary development permitting authority. They set land use policy which controls the type and location of future development and affect construction techniques by enforcing building and electrical codes. They direct the division of lots through subdivision ordinances. They also regulate the type, mix, and location of land uses using zoning ordinances.

Zoning ordinances implement policies established in local land use plans and reduce land use conflicts by dictating: 1) the type of development allowed within the jurisdiction; 2) the design of those uses; and 3 ) the way potentially conflicting uses may coexist.

Policies and standards reflect both technical information and popular opinion. Local land use law often reflects values that are difficult to evaluate objectively. Public participation in a project approval may reveal concerns for property values, neighborhood quality and scenic quality. These subjective values are difficult to put into laws. Few local governments have done more with energy facility regulation than provide a forurn for public involvement in siting decisions. 
Counties and incorporated cities prepare and adopt comprehensive land use plans which are acknowledged by a state-level commission. The plans indicate the location and significance of affected resources and provide a regulatory framework for potentially using them. If a conflict is identified which is resolved against energy resource development, then another site must be found, unless the plan is amended. If the conflict is resolved in favor of energy resource development then, from a land use perspective, resource use is feasible. Development still may be subject to conditions which mitigate negative impacts. These requirements are described in the plan and local ordinances. Thus, developers can use comprehensive plans to learn what kind of projects might be feasible, and under what conditions.

Some counties discuss renewable resources in their comprehensive plans. However, discussion in the plans has often not led to zoning and ordinances. Frequently, adequate and up-to-date data on resources' location, quantity, and quality has not been given to local governments. Also, energy issues are not a priority in land use planning circles or most local governments.

In the absence of attention to the energy resource in the local land use plan, a prospective developer may have to champion a project proposal through the entire land use planning, zoning, and ordinance-writing processes. Such an effort would add many months to a project's lead time and increase its cost. Along the way, design changes are likely or the project may be found infeasible. The local government and public would be involved in broad planning, policymaking, and ordinance issues in the context of community reaction to a proposed project.

\section{Determining Which Permits are Required}

To enable a developer to determine what local permits are necessary for a particular site, and for guidance in obtaining local permits, the following guidelines are provided.

- Determine with certainty within what local jurisdiction the project site lies. Assumptions about jurisdiction are often inaccurate. Even if a site is within the county, it is possible it may be within a city's Area of Impact, which would give the city certain jurisdiction over the project.

- Contact agency staff early to obtain information about permits and to discuss your plans. Go into their office in person to make personal contact and to show your commitment to expediting the permitting process.

- Determine what permits will be required for the proposed project; what information should be provided; the process that will be followed; and time frames, including submittal dates, hearing dates, and the time within which a decision can be expected.

- Get copies of the applicable regulations so you can personally review them and the evaluation criteria. Ask questions if the written regulations vary from information the staff has provided. 
- In the case of more discretionary permits, ask the staff about the likelihood of approval: also what might help to speed up the process and decision.

- Submit a complete application. Incomplete applications will result in processing delays.

- Attend all meetings where the application will be discussed. If there is no one to respond to questions, delays may occur or the permit may be denied.

Local county or city govemment is responsible for regulating development within local jurisdiction community. These requirements pertain to local zoning and building codes, comprehensive land use and shoreline plans, and local development policies.

Typical Washington State local permit requirements and the approximate time for processing are summarized in Table 14. A complete explanation of each permit and its fee structure follows.

\section{Land Use}

\section{Act: Shoreline Management}

Statutory Authority: RCW 90.58.140; Chapters 173-14 through -28 WAC

Agency: Department of Ecology (WDOE) and Local Planning Department

To determine whether this permit is needed, the Shoreline Master Program at the pertinent county or city office should be consulted. The plan will specify whether hydropower is an allowed use for the proposed area. The procedure for obtaining this permit varies from county to county. Generally, a public hearing is required. The Hearing Examiner will require an affidavit of public notice, a location map, a topographic map, and a site map. If a variance or conditional use permit is required, the Washington Department of Ecology (WDOE) must give the final approval. The Shoreline Management Permitting Process is indicated in Figure 21. SEPA compliance must be shown before final approval will be given.

\section{Permit or Regulation: Floodplain Development \\ Statutory Authority: Chapter 86.16 RCW; Chapter 173-158 WAC Agency: Local Planning Department}

Local govermments participating in the National Flood Insurance, Program (NFIP) are required to review proposed construction projects to determine if they are in identified floodplains as shown on the NFIP maps. If a project is located in a mapped floodplain, the local government must require a development permit to be obtained prior to construction. 


\section{Table 14}

\section{Typical Local Permit Requirements Washington State}

\begin{tabular}{|c|c|c|c|}
\hline Name & From & $\underline{\text { Reason }}$ & $\frac{\text { Approximate }}{\text { Time }}$ \\
\hline $\begin{array}{l}\text { Shoreline } \\
\text { Substantial } \\
\text { Development } \\
\text { Permit }\end{array}$ & $\begin{array}{l}\text { County Planning } \\
\text { Department }\end{array}$ & $\begin{array}{l}\text { Required if any part of project is } \\
\text { within } 200 \mathrm{ft} \text {. of an applicable } \\
\text { shoreline.1 }\end{array}$ & 4 mos. \\
\hline $\begin{array}{l}\text { Zoning Condi- } \\
\text { tional Use } \\
\text { Permit }\end{array}$ & $\begin{array}{l}\text { County Planning } \\
\text { Department }\end{array}$ & $\begin{array}{l}\text { Required if project is not in confor- } \\
\text { mance with zoning for county master plan }\end{array}$ & 3 mos. \\
\hline $\begin{array}{l}\text { Surface Water } \\
\text { Drainage Plan } \\
\text { Approval }\end{array}$ & $\begin{array}{l}\text { County Department } \\
\text { of Public Works }\end{array}$ & $\begin{array}{l}\text { Drainage plan must be approved before } \\
\text { several other permits can be } \\
\text { issued }\end{array}$ & $1 \mathrm{mo}$ \\
\hline $\begin{array}{l}\text { Commercial } \\
\text { Building } \\
\text { Permit }\end{array}$ & $\begin{array}{l}\text { County Building } \\
\text { and Plumbing } \\
\text { Department }\end{array}$ & $\begin{array}{l}\text { Applies to construction of power- } \\
\text { house }\end{array}$ & 2 wks. \\
\hline $\begin{array}{l}\text { Temporary Road } \\
\text { Closure Permit }\end{array}$ & $\begin{array}{l}\text { County Department } \\
\text { of Public Works }\end{array}$ & $\begin{array}{l}\text { Needed for any construction that would } \\
\text { completely close a road to traffic }\end{array}$ & 1 wk. \\
\hline $\begin{array}{l}\text { Utility } \\
\text { Permits }\end{array}$ & $\begin{array}{l}\text { County Department } \\
\text { of Public Works }\end{array}$ & Needed for Transmission lines/intertie & 2 wks. \\
\hline $\begin{array}{l}\text { Sewage Holding } \\
\text { Tank Variance }\end{array}$ & $\begin{array}{l}\text { County Department } \\
\text { of Health }\end{array}$ & $\begin{array}{l}\text { For sewage facilities installed as part of } \\
\text { the project on a permanent basis }\end{array}$ & 2 mos. \\
\hline Grading Permit & $\begin{array}{l}\text { County Department } \\
\text { of Public Works }\end{array}$ & $\begin{array}{l}\text { For all excavation or filling activities, ex- } \\
\text { cept as noted in the Uniform Building Code }\end{array}$ & $1 \mathrm{mo}$. \\
\hline Plumbing Permit & $\begin{array}{l}\text { County Building and } \\
\text { Plumbing Department }\end{array}$ & Must approve plumbing plans & 1 day \\
\hline $\begin{array}{l}\text { Inter-local } \\
\text { Agreement for } \\
\text { Construction on } \\
\text { County Roads }\end{array}$ & $\begin{array}{l}\text { County Department } \\
\text { of Public Works }\end{array}$ & $\begin{array}{l}\text { Short-term agreement applies to upgrading } \\
\text { and performing maintenance work on } \\
\text { county roads used by overweight con- } \\
\text { struction equipment }\end{array}$ & $\begin{array}{l}1 \text { mo. review } \\
3 \text { mos. agree- } \\
\text { ment }\end{array}$ \\
\hline $\begin{array}{l}\text { Permit to } \\
\text { Operate Over- } \\
\text { weight Vehicles } \\
\text { on City or } \\
\text { County Roads }\end{array}$ & $\begin{array}{l}\text { City/County } \\
\text { Department of } \\
\text { Public Works }\end{array}$ & $\begin{array}{l}\text { Required only where road conditions } \\
\text { are sensitive to damage by overweight } \\
\text { vehicles }\end{array}$ & 1 day \\
\hline
\end{tabular}




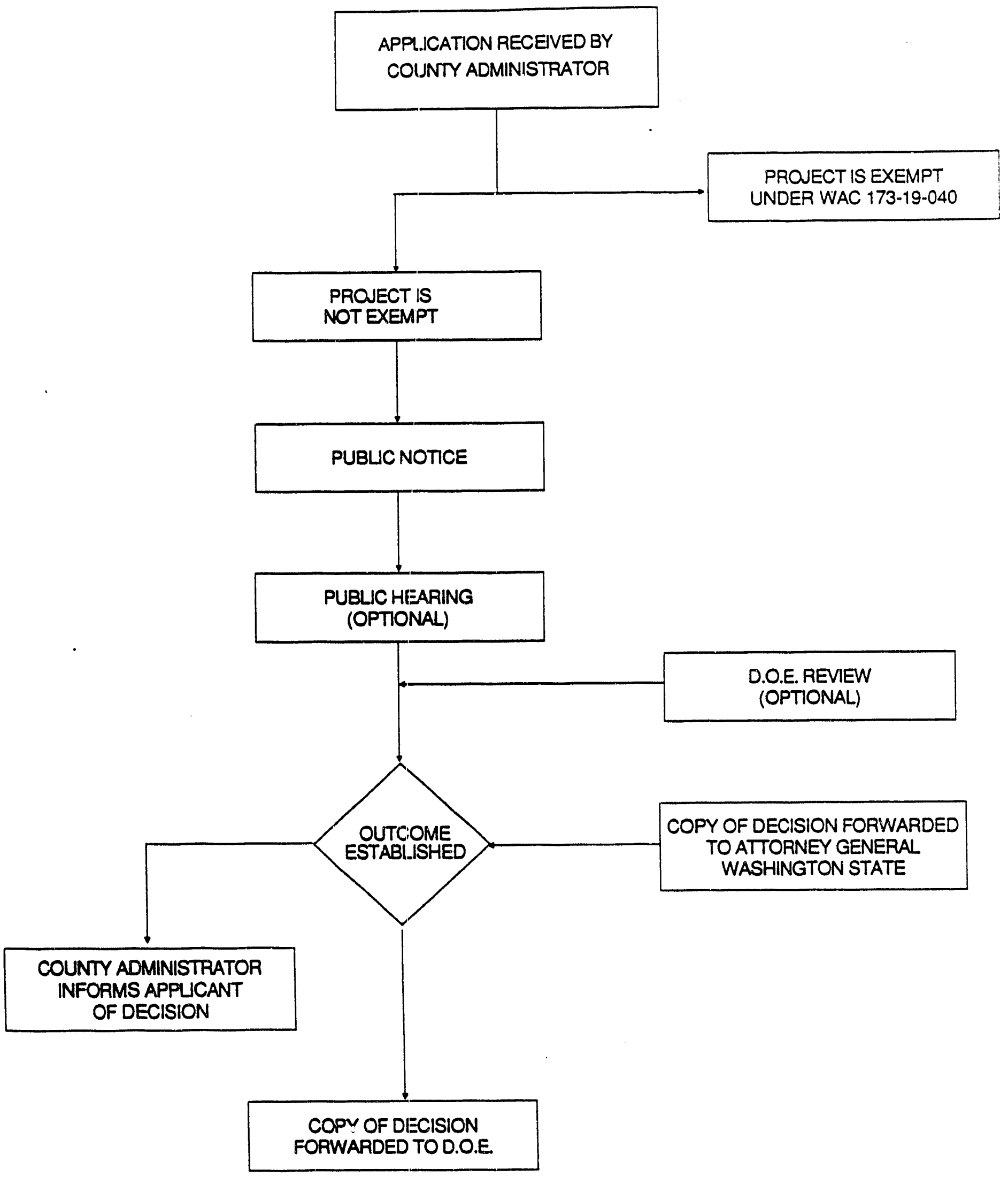

Figure 21: Washington Department of Ecology's Invoivement in the Shoreline Management Permitting Process 
Proposed projects are reviewed and conditions imposed on any permits issued to reduce the potential for damage from floodwaters. Permits are required for structures as well as for filling or grading activities in the floodplain.

State law requires that local entities have a local floodplain ordinance that meets or exceeds NFIP requirements. The Washington Department of Ecology (WDOE) has approval authority over these ordinances.

For permit applications or additional information, contact the local city or county building or planning department.

\section{Permit or Regulation: Zoning Conditional Use/Zoning Code Variance} Agency: County Boards of Commissioners, County Department of Public Works

In counties where a master plan is being implemented and where a project would conflict with planned land uses, a Conditional Use Permit or variance is required. The application is reviewed by a Hearing Examiner and requires a public hearing conducted by the Board of Commissioners. A preliminary drainage plan must be approved by the County Public Works Department prior to a public hearing for the substantial development and zoning permits.

\section{Permit or Regulation: Surface Water Drainage Plan Approval Statutory Authority: NA} Agency: Local Public Works Departments

The exact form required for this approval can be found in the local public works department Procedures Manual. A Preliminary Drainage Review of the natural and planned drainage improvements is prepared and used to determine if a Detailed Drainage Review is necessary.

A Drainage Plan Approval is needed prior to issuance of the following permits: Building, Grading, and Shoreline Development. The Preliminary Approval is sufficient for the Shoreline Development Permit hearings. There is no fee for the Preliminary Approval. The fee for the Detailed Review is based on the fee schedule for the associated local permits and approvals requiring the Drainage Plan. Prior to any site work, an inspection fee is required.

\section{Construction}

\section{Permit or Regulation: Commercial Building Agency: Local Planning Department, Building Permit Agency}

Permits to construct permanent buildings or additions to existing facilities are required by counties and cities. The application requires detailed final design plans for structures including electrical plan, plumbing plan, floor layout, sewage facilities, drainage plan, size and shape of lot and 
buildings, size and shape of foundation walls, beams, air vents, window accesses, and heating or cooling plants, if included in the design. Four sets of detailed plans and specifications must be included in the application.

The Building Permit is dependent on the approval of the Drainage Plan, Shoreline Development Permit, Zoning Variance, and SEPA compliance (the last two may or may not be required).

\section{Permit or Regulation: Plumbing, Electrical, Mechanical Agency: Local Building Permit Agency}

Plumbing, electrical, and mechanical plans prepared by a licensed plumber, electrician, engineer, or architect should be submitted along with an application card. The plans should show all fixtures that will be installed, the types and sizes of pipe, cable, etc., that will be used. A list of fixtures should also be included.

\section{Permit or Regulation: Interlocal Agreement for Construction on County Roads Agency: Local Department of Public Works}

The applicant initiates the short-term agreement by sending a letter to the director of the Department of Public Works describing the intended use and proposed upgrading and maintenance work. The letter should contain a draft contract for the agreement between the county and the applicant. The letter should include descriptions of proposed road construction, drawings illustrating materials to be used, and road bed and drainage design. A copy of the state environmental checklist or SEPA document should also be included.

\section{Permit or Regulation: Temporary Road Closure Agency: Local Department of Public. Works}

This permit can be granted over the counter to the contractor 5 days before it is needed. The application calls for a description of the proposed activity, the construction schedule, and the exact location of the proposed road closure.

\section{Permit or Regulation: Grading Permit Agency: Local Planning Department}

Plans and specifications containing the following inform ation should be submitted: the rature, extent, location, and compliance with the Uniform Building Code; existing contours, terrain, and area of drainage; limiting dimensions, contours, and proposed drainage channels after construction; plans and maps for all drainage devices, walls, cribbing, or dams; estimated area runoff; and the location of any existing or proposed building in the grading area. A Soil Engineering Report, the status of SEPA compliance and other local permits, and the Surface Water Drainage Plan should also be included. 
This permit cannot be issued until SEPA compliance is established.

Permit or Regulation: Operate Overweight Vehicles on City or County Roads Agency: Local Department of Public Works

This permit may be obtained by the contractor. The following information is required for each application: 1) the size and number of tires; 2) weight of vehicle; and 3) the current registration of the vehicle.

\section{Permit or Regulation: Utility}

Agency: Local Department of Public Works

A letter requesting this permit should be sent to the local Department of Public Works. It should include a set of plans relating to the transmission line leading from the power house to the intertie, a description of the proposed construction of the transmission line, and a construction schedule.

Permit or Regulation: On-Site Sewage Disposal Permit

Statutory Authority: Chapter 90.48 RCW; Chapter 173-240 WAC

Agency: Local Health Department, Washington State Department of Social and

Health Services (WDSHS), or Washington Department of Ecology (WDOE)

Businesses and residences that locate outside areas served by sewer systems frequently treat and dispose of sewage through septic tanks and subsurface disposal field on the property where it originates. These systems require approval of local health departments, Washington Department of Social and Health Services, or the Washington Department of Ecology, depending on the size and nature of the system. Local health departments issue permits for on-site sewage with design flows, at any common point, less than 3,500 gallons/day.

\section{Other Permits}

\section{Permit or Regulation: Noise Ordinances Statutory Authority: Chapter 173-60 WAC Agency: Local Planning Department}

Noise abatement and control is primarily the role of local government, and many local entities have adopted noise ordinances. Chapter 173-60 WAC, Maximum Environmental Noise Levels, establishes noise levels that cannot legally be exceeded. Permissible noise levels established by this regulation vary depending on the source of noise (residential, commercial, industrial), and source receiving the noise. For more information about noise ordinances that apply in your area, contact your local planning department. 


\section{GLOSSARY}

\section{A-95 REVIEW}

ACRE-FOOT

\section{ADVERSE WATER} CONDITIONS

ALTERNATING CURRENT (AC)

AMW

ARCHAEOLOGY

AVAILABILITY FACTOR

AVERAGE-WATER YEAR

AVOIDED COST

\section{BASE LOAD}

BASE LOAD STATION

BIA

BLM

BPA

BRITISH THERMAL UNIT
State coordinated review of federally funded projects.

The amount of water required to cover 1 acre to a depth of 1 foot. This is equivalent to 325,851 gallons, 43,560 cubic feet, $1,233.5$ cubic meters, or 1.2335 cubic decameters.

Water conditions that limit the hydroelectric generation by either a low water supply or a reduced head.

Electricity that reverses its direction of flow periodically, as contrasted to direct current (DC).

Average Megawatt

The subfield of anthropology engaged in the theory and practice of recovering, analyzing, interpreting, and explaining evidence of the human prehistoric and historic past; the time-depth arm of anthropology. Archaeology as a scholarly endeavor is not limited in the scope of its subject matter by legal or regulatory provisions such as the minimum age assigned to archaeological resources (for enforcement purposes) by the Archaeological Resources Protection Act.

The percentage of time a plant is available for power production.

The average annual flow of water available for hydropower generation calculated over a long period, usually 10 to 50 years.

The payment made for the capacity and energy of a small power project. Such payment equals the cost to a utility of obtaining and operating additional generating units, or to purchase power from another source, if this power were not available. Also called avoidable cost.

The amount of electric power needed to be delivered at all times and all seasons.

A power generating station usually operated at a constant output to take all or part of the base load of a system.

Bureau of Indian Affairs

U.S. Bureau of Land Management

Bonneville Power Administration

Quantity of heat required to raise the temperature of one pound of water $1^{\circ} \mathrm{F}$. 
Btu

CANDIDATE SPECIES

CAPACITY

CAPACITY FACTOR

CAPACITY VALUE

CFR

CFS

CHECK STRUCTURE

CIRCUIT BREAKER

CIVIL WORKS

COOPERATING AGENCY

CORPS

$\mathrm{COU}$

CRITICAL HABITAT
See British thermal unit.

Any species being considered by the Secretary of Interior for listing as an endangered species or a threatened species. Separate lists for plants, animals, and invertebrates are published periodically in the Federal Register.

The maximum power output or the load for which a generating unit, generating station, or other electrical apparatus is rated. Common units include kilovolt-ampere $(\mathrm{kVa})$, kilowatt $(\mathrm{kW})$, and megawatt $(\mathrm{MW})$.

The ratio of the energy that a plant produces to the energy that would be produced if it were operated at full capacity throughout a given period, usually a year. Sometimes called the plant factor.

The part of the market value of electric power that is assigned to dependable capacity.

Code of Federal Regulations, published by the Office of the Federal Registrar, National Archives and Records Service of the General Services Administration.

Cubic feet per second.

A structure where water flow is regulated and measured.

A switch that automatically opens to cut off an electric current when an abnormal condition occurs.

All the works of a facility associated with plant structures, impounding channeling, and emergency release of water, etc.

Any federal agency other than a lead agency which has jurisdiction by law or special expertise with respect to any environmental impact involved in a proposal (or a reasonable alternative) for legislation or other major federal action significantly affecting the quality of the human environment. The selection and responsibilities of a cooperating agency are described in 1501.6. A state or local agency of similar qualifications or, when the effects are on a reservation, an Indian tribe may by agreement with the lead agency become a cooperating agency.

Corps of Engineers

Consumer-owned utility

An area designated as such in the BLM Manual and is any air, land, or water area (exclusive of those existing manmade structures or settlements which are not necessary to the survival and recovery of a listed species) and constit- 
CRITICAL HEAD

CUBIC FEET PER

SECOND (cfs, $\left.\mathrm{ft}^{3} / \mathrm{s}\right)$

CUP

DEMAND

DEPENDABLE CAPACITY

DESIGN HEAD

DESTRUCTION or ADVERSE MODIFICATION

DIRECT CURRENT (DC)

EIS

ENERGY DISSIPATER

ENVIRONMENTAL EFFECTS uent elements thereof, the loss of which would appreciably decrease the likelihood of the survival and recovery of a listed species or a distinct segment of its population. The constituent elements of Critical Habitat include, but are not limited to: physical structure and topography, biota, climate, human activity, and the quality and chemical content of land, water, and air. Critical Habitat may represent any portion of the present habitat of a listed species and may include additional areas for reasonable population expansion.

The head at which the output of a turbine at full gate equals the name plate rating of an associated generator.

A flow equal to 646,317 gallons per day or 0.028317 cubic meters per second $\left(\mathrm{m}^{3} / \mathrm{s}\right)$. Also called a second feet.

\section{Conditional Use Permit}

The rate at which electrical energy is delivered to a system, to part of a system, or to a piece of equipment; it is usually expressed in kilowatts, megawatts, etc.

The minimum capacity available at any time during a study period. This value is generally determined by optimizing plant operation during the driest period when the least water is available.

The head at which the runner of a turbine is designed to provide the highest efficiency.

Direct or indirect alteration of Critical Habitat which appreciably diminishes the value of the habitat for both the survival and recovery of a listed species. Such alterations include, but are not limited to, alterations adversely modifying any of those physical or biological features that were the basis for determining the habitat to be critical.

Electricity that flows continuously in one direction, as contrasted with alternating current (AC).

Environmental Impact Statement

A device used to reduce water pressure to a level safe for certain uses.

Direct effects, which are caused by the action and occur at the same time and place. Indirect effects, which are caused by the action and are later in time or farther time or farther removed in distance, but are still reasonably foreseeable. Indirect effects may include growth inducing effects and other effects related to induced changes in the pattern of land use, population density or growth rate, and related effects on air and water and other natural systems, including ecosystems. Effects and impacts are used in [the CEQ] 
ENVIRONMENTAL IMPACT STATEMENT (EIS)

EPA

ESSENTIAL HABITAT

EXTRA HIGH VOLTAGE (EHV)

FEASIBILITY STUDY

FEDERAL ENERGY

REGULATORY COMMISSION (FERC)

FIXED COSTS

FLOW-DURATION CURVE

GENERATOR

GIGAWATTHOUR (GWh)

GROUNDWATER

HABITAT regulations are synonymous. Effects includes ecological (such as the effects on natural resources and on the components, structures, and functioning of affected ecosystems), aesthetic, historic, cultural, economic, social, or health, whether direct, indirect, or cumulative. Effects may also include those resulting from actions which may have both beneficial and detrimental effects, even if on balance the agency believes that the effect will be beneficial.

A detailed written statement as required by section 102(2)(C) of the National Environmental Policy Act.

\section{U.S. Environmental Protection Agency}

Criteria for identifying are the same as for Critical Habitat, the only difference being that the area has not been officially designated as Critical Habitat.

A term applied to voltage levels of transmission lines that are higher than the voltage levels commonly used. At present, electrical utilities consider EHV to be any voltage of 345,000 volts or higher. See ultrahigh voltages.

An investigation to develop a project and definitively assess its desirability for implementation.

An agency in the U.S. Department of Energy, that licenses non-federal hydropower projects and regulates the interstate transfer of electrical energy.

Costs associated with plant investment, including debt service, interim replacement, and insurance.

A curve of flow values plotted in descending order of magnitude against time intervals, usually in percentages of a specified period. For example, the curve might show that over a period of a year, a river flows $500 \mathrm{cfs}$ or more 10 percent of the time, and $100 \mathrm{cfs}$ or more 80 percent of the time.

A machine that converts mechanical energy into electrical energy.

One million kilowatthours $(\mathrm{kWh})$.

The supply of water under the earth's surface, as contrasted to surface water.

The place where an organism (plant or animal) lives. There are four major divisions of habitat, namely, terrestrial, freshwater, estuarine, and marine. 
HEAD

HISTORIC PRESERVATION

HISTORIC PROPERTY or HISTORIC RESOURCE

HYDROPOWER PLANT

IDFG

IDHW

IDL

IDLIS

IDPR

IDT

IDWR

IMPOUNDMENT

INSTALLED CAPACITY

INTERRUPTIBLE ENERGY

IPUC

ISHPO

$\mathrm{kV}$
The difference in elevation between two water surfaces. In hydropower, the net head refers to the difference in elevation between the headwater surface above and the tailwater below a hydropower plant, minus friction losses.

Includes identification, evaluation, recordation, documentation, curation, acquisition, protection, management, rehabilitation, restoration, stabilization, maintenance, reconstruction, or any combination of the foregoing activities.

Any prehistoric or historic district, site, building, structure, or object included in, or eligible for inclusion in, the National Register. The term includes, for purposes of these regulations, artifacts, records, and remains that are related to and located within such properties. The term 'eligible for inclusion in the National Register' includes both properties formally determined as such by the Secretary of the Interior and all other properties that meet National Register listing criteria.

An electric power plant in which the energy of falling water is converted into electricity by turning a turbine-generator unit. Also called a hydroelectric power plant, a hydroelectric plant, or simply a hydro plant.

Idaho Department of Fish and Game

Idaho Department of Health and Welfare

Idaho Department of Lands

Idaho Department of Labor and Industrial Services

Idaho Department of Parks and Recreation

Idaho Department of Transportation

Idaho Department of Water Resources

A reservoir or artificial pond created behind a dam.

The total of the capacities shown on the nameplates or the generating units in a hydropower plant.

Energy that can be curtailed at the supplier's discretion.

Idaho Public Utility Commission

Idaho State Historic Preservation Office

Kilovolt 
KILOWATT $(\mathrm{kW})$

kWh

LOAD

LOAD FACTOR

LOW-HEAD HYDROPOWER

MCA

MDC

MDFWP

MDHES

MDLI

MDNRC

MDSL

MDT

MEGAWATT (MW)

MGD

MPSC

MSHPO

NAMEPLATE RATING
One thousand watthours (Wh)-the amount of electrical energy produced or consumed by a one kilowatt unit for one hour.

Kilowatt hour

The amount of power required at a given point or points in an electric system.

The ratio of the average load to the maximum load during a given period.

Hydropower that operates with a head of 20 meters (66 feet) or less.

Montana Code Annotated

Montana Department of Commerce

Montana Department of Fish, Wildlife, and Parks

Montana Department of Health and Environmental

Sciences

Montana Department of Labor and Industry

Montana Department of Natural Resources and Conservation

Montana Department of State Lands

Montana Department of Transportation

One thousand kilowatts (kW) or one million watts (W).

Million gallon per day, equivalent to 1.457 cubic feet per second (cfs).

Montana Public Service Commission

Montana State Historic Preservation Office

The full-load continuous rating of a generator or other electrical equipment under specified conditions as designated by the manufacturer and written on the nameplate.

NATIONAL ENVIRONMENTAL An act, passed in 1969, requiring that the environmental POLICY ACT (NEPA) impact of most projects and programs be identified. Among its important provisions is one requiring a detailed statement of environmental impact of, and altematives to, a project to be submitted to the federal government before the project can begin. 
NEGATTVE DECLARATION

NPPC

ODEQ

ODFW

ODLCD

ODOA

ODOE

ODOF

ODOT

ODSL

OEFSC

OFF-PEAK

OLCDC

ON-PEAK

OPUC

OUTAGE

OUTAGE, FORCED

OUTAGE, SCHEDULED

OUTPUT

OWRC

OWRD
The document satisfies the CEQA requirement if no significant environmental impacts would result from a project as determined by an initial study.

Northwest Power Planning Council

Oregon Department of Environmental Quality

Oregon Department of Fish and Wildlife

Oregon Department of Land Conservation and Development

Oregon Department of Agriculture

Oregon Department of Energy

Oregon Department of Forestry

Oregon Department of Transportation

Oregon Division of State Lands

Oregon Energy Facility Siting Council, seven-member council that coordinates and approves siting for large power plants.

The time of day and week when the demand for electricity is low; see on-peak.

Oregon Land Conservation Development Commission, state appointed commission to determine land use policy.

The time of day and week when demand for electricity in a region is high.

Oregon Public Utility Cornmission

The period in which a facility is out of service.

The shutdown of a facility for emergency reasons.

The shutdown of a facility for inspection or maintenance, as scheduled.

The amount of power or energy delivered from a piece of equipment, a station, or a system.

Oregon Water Resources Commission

Oregon Water Resources Department 
PEAKING UNIT

PENSTOCK

PLANT FACTOR

PRELIMINARY PERMIT

PSI

PURPA

QUAD

QUADRILLION Btu

RIPARIAN RIGHTS

ROYALTY

RPM

RUN-OF-THE-RIVER

SBA

SECOND-FEET

SEEPAGE

SEPA
An auxiliary electric power system that is used to supplement the power supply system during periods of peak demand for electricity. Peaking units are usually old, lowcost, inefficient units having a high fuel cost, or hydroelectric units having low firm capacity.

See pressure pipe used to carry water to a turbine.

See capacity factor.

An initial permit issued by the Federal Energy Regulatory Commission (FERC) for hydropower projects. The permit does not authorize construction, but during the permit's term of up to 36 months, the permittee is given the right of priority-of-application for a license while completing the necessary studies to determine the engineering and economic feasibility of the proposed project, the market for the power, and all other information necessary for inclusion in an application for license.

A unit of pressure as measured in pounds per square inch.

Public Utility Regulatory Policies Act of 1978. This act requires utilities to purchase power from and interconnect with a privately developed facility and mandates the state utility regulatory agency to set a "just and reasonable price."

Quadrillion Bru.

An amount of energy equal to the heat value of 965 billion cubic feet of gas, 175 million barrels of oil (DOE), or 38 million tons of coal.

The rights of land owner's to the water on or bordering their property, including the right to prevent diversion or misuse of upstream water.

The portion of the proceeds paid to the title holder in exchange for exploitation of a property.

Revolution per minute.

A hydropower plant that uses the flow of a stream as it occurs with little or no reservoir capacity for storing water. Sometimes called a stream flow plant.

Small Business Administration.

Cubic feet per second (cfs).

Water that flows through the soil.

State Environmental Policy Act 
SPILLWAY

SPINNING RESERVE

STREAM FLOW

SURFACE WATER

SWITCHING STATION

THERM

THERMAL PLANT

TRANSFORMER

TRANSMISSION

ULTRAHIGH VOLTAGES

(UHV)

USCE

USGS

WAC

WATERMASTER

WDF

WDNR

WDOC

WDOE

WDOT
A passage used for running surplus water over or around a dam.

Generating capacity, on line in excess of the load on the system that is ready to carry additional electrical load.

The amount of water passing a given point in a stream or river in a given period, usually expressed in cubic feet per second (cfs), or million gallons per day (MGD).

Water on the earth's surface that is exposed to the atmosphere such as rivers, lakes, oceans, as contrasted to groundwater.

An assemblage of equipment used for the sole purpose of typing together two or more electric circuits through selectively arranged switches that permit a circuit to be disconnected in case of trouble or to change electric connections between circuits. A type of substation.

The equivalent of 100,000 Btu.

An electric generating plant that uses heat to produce electricity. Such plants may burn coal, gas, oil, biomass, or use nuclear energy to produce thermal energy.

A device used to change the voltage of alternating current (AC) electricity.

The act or process of transporting electrical energy in bulk from a source or sources of supply to other principal parts of a system or to other utility systems.

Voltages greater than 765,000 volts. See extra high voltage (EHV).

\section{U.S. Army Corps of Engineers}

U.S. Geological Survey

Washington Administrative Code

Employed by Oregon Water Resources Department, allocates available surface or groundwater in state.

Washington State Department of Fisheries

Washington Department of Natural Resources

Washington State Department of Commerce

Washington Department of Ecology

Washington State Department of Transportation 
WDSHS

WDSL

WDW

WEFSEC

WHEELING

WOAHP

WPCF

WPPSS

WSEO

WUTC
Washington State Department of Social and Health Services

Washington Division of State Lands

Washington State Department of Wildlife

Washington Energy Facility Site Evaluation Council

The transportation of electricity by an electric utility over its lines for another utility.

Washington State Office of Archaeological and Historic Preservation

Water Pollution Control Facility

Washington Public Power Supply System

Washington State Energy Office

Washington State Utilities and Transportation Commission 
Bonneville Power Administration

r.O. Box 3627

Portland, OR 97208

(503) 230-3000

Fish and Wildlife Service

Region I

U.S. Fish and Wildlife Service

911 NE 11 th Avenue

Portland, OR 97232-4181

(503) 231.6159

\title{
Regional Offices
}

U.S. Fish and Wildlife Service

Boise Field Office

4696 Overland Road, Room 576

Boise, ID 83705

(208) 334-1931

U.S. Fish and Wildlife Service

Olympia Field Office

3704 Griffin Lane, Suite 102

Olympia, WA 98501

(206) $753-9440$

U.S. Fish and Wildlife Service

Portland Field Office

2600 SE 98th Avenue, Suite 100

Portland, OR 97266

(503) 231-6179

U.S. Fish and Wildlife Service

Montana Regional Office

P.O. Box 25486

Denver Federal Center

Denver, CO 82225

(303) 236-7920

\author{
Air Quality \\ Environmental Protection Agency (EPA), Region X \\ 1200 Sixth Avenue \\ Seattle, WA 98101 \\ (206) 442-1275
}

EPA, Region I (Idaho, Oregon, Washington)

$911 \mathrm{NE} 11$ th Avenue

Portland, OR 97232-4181

(503) 231-6159

Region 8 (Montana)

Environmental Protection Agency

999 18th Street, Suite 500

Denver, CD 80202-2405

(303) 293-1603

Regional Offices

EPA Operations Office

c/o State Department of Ecology

PV-11

Olympia, WA 98504

(206) 459-6000

Oregon Department of Environmental Qualities 811 SW 6th

Purtland, OR 97204

(503) 229-5630

$1-800-452-4011$

Idaho Department of Health \& Welfare

Bureau of Air Quality

1410 N Hiltc $n$

Boise, ID 83706

(208) 334-5898 
Forest Service

Northern Region

U.S. Forest Service

Northern Region

Federal Building

P.O. Box 7669

Missoula, MT 59807

(406) 329-3518

\section{Bureau of Land Management \\ State Offices \\ Oregon (Washington) \\ Bureau of Land Management \\ 825 NE Multnomah \\ P.O. Box 2965 \\ Portland, OR 97208 \\ (503) 231-6281}

Montana

Bureau of Land Management 222 N 32nd Street

P.O. Box 26800

Billing, MT 59107

(406) 255-2885

\section{District Offices}

Klamath Falls Resource Area 2795 Anderson Avenue, Suite 25 Klamath Falls, OR 97603-7891

(503) 883-6916

Prineville District

185 E 4th Street

P.O. Box 550

Prineville, OR 97754

(503) 447-4115

Eugene District

1255 Pearl Street

P.O. Box 10226

Eugene, OR 97401

(503) 683-6600

Medford District

3040 . iddle Road

Medford, OR 97501

(503) $770-2200$

Vale District

100 Oregon Street

Vale, OR 97918

(503) 473-3144

\section{Intermountain Region}

U.S. Forest Service

Intermountain Region

324 25th Street

Ogden, UT 84401

(801) 625-5149

Idaho

Bureau of Land Management

3380 Americana Terrace

Boise, ID 83706

(208) 334-1414
Burns District

HC 74-12533 Highway $20 \mathrm{~W}$

Hines, OR 977:38

Salem District

1717 Fabry Road SE

Salem, OR 97306

(503) 399-5646

Tillamook Resource Area

6615 Officer's Row

Tillamook, OR 97141

(503) $842-7546$

Roseburg District

777 NW Garden Valley Boulevard

Roseburg, OR 97470

(503) 672-4491

Coos Bay District

1300 Airport Lane

North Bend, OR 97459

(503) 756-0100 
Spokane District

E 4217 Main

Spokane, WA 99202

(509) 353-2570

$1133 \mathrm{~N}$ Western Avenue

Wenatchee Resource Area

Wenatchee, WA 98801

(509) 662-4223

\section{BLM Board of Land Appeals}

Office of Hearings and Appeals

Arlington, VA 22203

Office of Environmental Project Review

Department of the Interior

Regional Environmental Officer

Oregon, Washingion, Idaho

911 NE 11 th Avenue

Portland, OR 97232-4181

(503) 231-6157

\section{Bureau of Reclamation}

Regional Director

Pacific Northwest Region

Bureau of Reclamation

Box 043

$550 \mathrm{~W}$ Fort Street

Boise, ID 83724-0043

(208) 334-1905

\section{Corps of Engineers}

District Engineer

U.S. Army Engineer District

Walla Walla, WA 99362

(509) $522-6720$

Field Offices

Corps of Engineers

Lucky Peak Project Office

HC-33, Box 1020

Boise, ID 83706

(208) 343-0671

Corps of Engineers

P.O. Box 2946

Portland, OR 97208-2946

(503) 326-6995
Baker Resource Area

P.O. Box 987

Baker, OR 97814

(503) 523-6391
Department of Interior

Associate Solicitor

Office of Environmental Affairs

Division of Energy and Resources

Office of the Solicitor

Washington, DC 20240
Corps of Engineers

c/o Forest Service

1201 Ironwood Drive

Coeur d' Alene, ID 83814

(208) 765-7237

Corps of Engineers (Montana)

$215 \mathrm{~N} 17$ th Street

Omaha, NE 68102

(402) $221-4125$

Northwest Power Planning Council

851 SW 6th, Suite 1100

Portland, OR 97204-1348

1-800-222-3355 (503) 222-5161 
Environmental Protection Agency

Environmental Impact Review Officer

Environmental Protection Agency-Region X .

1200 Sixth Avenue

Seattle, WA 98101

(206) $442-1200$

\section{Bureau of Indian Affairs}

Director

P. O. Box 10

Phoenix, AZ 85011

(602) $379-6600$

Columbia River Intertribal Fishery Commission 975 SE Sandy Boulevard, Suite 202

Portland, OR 97214

(503) 238-0667

Federal Aviation Administration

Washington \& Oregon Regional Office 1601 Lind Avenue SW

Renton, WA 98055

(206) 227-2001

Boise Airport Traffic Control Tower

3105 Airport Way

Boise, ID 83705

(208) 334-1642

Federal Communications Commission

Washington, Oregon, Idaho, \& Montana

Building A

11410 NE 122nd Way, Suite 312

Kirkland, WA 98034

(206) 821-9037

U.S. Fish and Wildlife Service

Boise Field Office

4696 Overland Road, Room 576

Boise, ID 83705

(208) 334-1931
Director

911 NE 11 th Avenue

Portland, OR $97232-4169$

(503) 231-6702

Flight Standards District Office

FAA Building

Helena Regional Airport

Helena, MT 59601

(406) 449-5434

Division of Fish and Wildlife Enhancement

Drawer 10023, Federal Building

301 S Park

Helena, MT 59626

(406) 449-5225 


\section{Federal and State Offices - Idaho}

Federal Agencies to Contact for Hydroelectric Development

Bonneville Power Administration

P.O. Box 3627

Portland, OR 97208

(503) 230-3000

Fish and Wildlife Service

U.S. Fish and Wildlife Service

Boise Field Office

4696 Overland Road, Room 576

Boise, ID 83705

(208) 334-1931

Forest Service

Northern Region

U.S. Forest Service

Clearwater National Forest

Federal Building

P.O. Box 7669

12730 Highway 12

Missoula, MT 59807

Orofino, ID 83544

(406) 329-3511

(208) 476-4541

Nez Perce National Forest

Panhandle National Forest

Route 2, Box 475

Grangeville, ID 83530

(208) 983-1963

1201 Ironwood Drive

Coeur d'Alene, ID 83814

(208) 765-7223

Bitterroot National Forest

$316 \mathrm{~N}$ 3rd Street

Hamilton, MT 59840

(406) 363-3131

Intermountain Region

U.S. Forest Service

Boise National Forest

324 25th Street

1750 Front Street

Ogden, UT 84401

Boise, ID 83702

(801) 625-5431

(208) $364-4100$

Caribou National Forest

250 S 4th Avenue, Suite 294

Pocatello, ID 83201

(208) 236-7500

Payette National Forest

P.O. Box 1026

McCall, ID 83638

(208) 634-1333

Challis National Forest

H/C 63, Highway 93

P.O. Box 1671

Challis, ID 83226

(208) 879-2285

Salmon National Forest

P. O. Box 729

Salmon, ID 83467

(208) 756-2215

Sawtooth National Forest

2647 Kimberly Road E

Twin Falls, ID 83301

(208) 737-3200 
Targhee National Forest

$420 \mathrm{~N}$ Bridge Street

P.O. Box 208

St. Anthony, ID 83445

(208) 624-3151

Bureau of Land Management

U.S. Bureau of Land Management 3380 Americana Terrace

Boise, ID 83706

(208) 334-1414

\section{District Offices}

Boise District Office

3948 Development Avenue

Boise, ID 83705

(208) 334-1582

Idaho Falls District Office

940 Lincoln Road

Idaho Falls, W 83401

(208) 529-1020

Shoshone District Office

P. O. Box 2-B

Shoshone, ID 83352

(208) 886-2206
Burley District Office

Route 3, Box 1

Burley, ID 83318

(208) 678-5514

Salmon District Office

P. O. Box 430

Salmon, ID 83467

(208) $756-5400$

Coeur d'Alene District Office 1808 N 3rd Street

Coeur d'Alene, ID 83814

(208) 765-1511

Office of Environmental Project Review

Department of the Interior

Office of Environmental Affairs

911 NE 11 th Avenue

Portland, OR 972324181

(503) $231-6157$

Bureau of Reclamation

Pacific Northwest Region

Bureau of Reclamation

Box 043

$550 \mathrm{~W}$ Fort Street

Boise, ID 83724-0043

(208) 334-1905

Corps of Engineers

District Engineer

U.S. Army Engineer District

Walla Walla, WA 99362

(509) 522-6720 
Idaho Field Offices

Corps of Engineers

Lucky Peak Project Office

Corps of Engineers

c/o Forest Service

HC-33, Box 1020

Boise, ID 83706

1201 Ironwood Drive

(208) 343-0671

Coeur d'Alene, ID 83814

(208) 765-7237

National Park Service

Regional Director

Pacific Northwest Region

National Park Service

Attn: Regional Environmental Coordinator

83 S King Street, Suite 212

Seattle, WA 98104

(206) 442-5565

Environmental Protection Agency

Environmental Impact Review Officer

Environmental Protection Agency-Region X

1200 Sixth Avenue

Seattle, WA 98101

(206) 442-1200

Bureau of Indian Affairs

Director

Director

P. O. Box 10

911 NE 11 th Avenue

Phoenix, AZ 85011

Portland, OR 97232-4169

(602) $379-6600$

(503) 231-6702

Columbia River Intertribal Fishery Commission

975 SE Sandy Boulevard, Suite 202

Portland, OR 97214

(503) 238-0667

Federal Aviation Administration

Boise Airport Traffic Control Tower

3105 Airport Way

Boise, ID 83705

(208) 334-1642

\section{State Agencies to Contact for Hydroelectric Development}

Idaho Department of Water Resources

Statehouse Mail

1301 N Orchard Street

Boise, ID 83720

(208) $327-7900$ 
Regional Offices of Water Resources

Northern Region

1910 NW Boulevard, Suite 210

Coeur d'Alene, ID 83814

(208) 765-4639

Eastern Region 150 Shoup, Suite 15

Idaho Falls, ID 83402

(208) $525-7161$

Idaho Department of Fish and Game $600 \mathrm{~S}$ Walnut Street

P. O. Box 25

Boise, ID 83707

(208) 334-3771

\section{Regional Offices}

Region 1

2320 Government Way

Coeur d'Alene, ID 83814

(208) 765-3111

Region 3

$109 \mathrm{~W}$ 44th Street

Boise, ID 83714

(208) 327-7025

Region 4

868 E Main

P O. Box 428

Jerome, ID 83338

(208) 324-4359

Region 6

1515 Lincoln Road

Idaho Falls, ID 83401

(208) 525-7290

Idaho Department of Parks and Recreation

Statehouse Mail

Boise, ID 83720

(208) 334-2154

Idaho Public Utilities Commission

$472 \mathrm{~W}$ Washington

Boise, ID 83702

(208) $334-0300$

Idaho State Historic Preservation Office

Idaho State Historical Society

210 Main Street

Boise, ID 83702

(208) 334-3847
Southern Region 222 Shoshone Street E

Twin Falls, ID 83301

(208) $734-3578$

Western Region

2735 Airport Way

Boise, ID 83705

(208) 334-2190
Region 2

1540 Wamer Avenue

Lewiston, ID 83501

(208) 743-6502

McCall Subregion

P. O. Box 905

McCall, ID 83638

(208) 634-8137

Region 5

1345 Barton Road

Pocatello, ID 83204

(208) $232-4703$

Salmon Subregion

P. O. Box 1336

Salmon, ID 83467

(208) 756-2271 
Idaho Department of Health and Welfare

Division of Environmental Quality

Department of Health and Welfare

$1410 \mathrm{~N}$ Hilton, Suite 101

Boise, ID 83720

(208) 334-5867

Field Offices

Coeur d'Alene Field Office

2110 Ironwood Parkway

Coeur d'Alene, ID 83814

(208) 667-3524

Pocatello Field Office

224 S Arthur

Pocatello, ID 83204

(208) 236-6160

Idaho Department of Lands

Statehouse Mail, Room 121

Boise, ID 83720

(208) $334-3280$

Idaho Department of Labor and Industrial Services

Statehouse Mail

$277 \mathrm{~N} 6$ th

Boise, ID 83720

(208) $334-3950$

Idaho Transportation Department

P.O. Box 7129

Boise, ID 83707

(208) $334-8000$
Lewiston Field Office

1118 F Street

Lewiston, ID 83501

(208) 799-3430

Twin Falls Field Office

P. O. Box 1626

Twin Falls, ID 83303

(208) 734-9520 


\section{Montana State Agencies}

Montana Department of Natural Resources

and Conservation

Cogswell Building

1520 E Sixth Avenue

Helena, MT 59620

(406) 444-6699

Building Codes Bureau

1218 E Sixth Avenue

Helena. MT 59620

(406) 444-3494

Montana Department of Commerce

1424 Ninth Avenue

Helena, MT 59620

(406) 444-3494

Montana Board of Natural Resources and Conservation

Cogswell Building

1520 E Sixth Avenue

Helena, MT 59620

(406) 444-6699

Montana Department of Health \&

Environmental Sciences

Cogswell Building

1520 E. Sixth Avenue

Helena, MT 59620

(406) 444-3948

Montana Water Rights Bureau

Field Offices

Bozeman

$111 \mathrm{~N}$ Tracy

Bozeman, MT 59715

(406) $586-3136$

Missoula

Holiaay Village Professional Plaza

Suite 105

P.O. Box 5004

Missoula, MT 59806

(406) $721-4284$

Helena

1520 E Sixth Avenue

Helena, MT 59620

(406) 444-6695

Kalispell

3220 Highway $93 \mathrm{~S}$

P.O. Box 860

Kalispell, MT 59903-0860

(406) $752-2288$

Havre

$1708 \mathrm{~W} 2$ 2nd Street

P.O. Box 1828

Harve, MT 59501

(406) 265-5516

Glasgow

8391 st Avenue S

P.O. Box 1269

Glasgow, MT 59230

(406) 228-2561 
Lewistown

204 S Daws

P.O. Box 438

Lewistown, MT 59457

(406) 538-7459

Billings

1537 Avenue D, Suite 105

Billings, MT 59102

(406) 657-2105

Montana State Historic Preservation Office

Montana Historical Society

225 N Roberts

Helena, MT 59620

(406) 444-7715

Montana Department of State Lands

1625 Eleventh Avenue

Helenn, MT 59620

(406) 444-2074

Board of Land Commissioners

1625 Eleventh Avenue

Helena, MT 59620

(406) 444-2074

Montana Department of Fish, Wildlife, and Parks 1420 E Sixth Avenue

Helena, MT 59620

(406) 444-3186

Montana Department of Transportation

2701 Prospect Avenue

Helena, MT 59620

(406) 444-6201

Montana Department of Labor and Industry

Lockey and Roberts

Helena, MT 59620

(406) 444-3555
Miles City

5 N Prairie Avenue

P.O. Box 276

Miles City, MT 59301

(406) 232-6359 


\section{Oregon Addresses}

Building Codes Agency

1535 Edgewater NW

Salem, Oregon 97310

(503) 373-1248

(503) $378-3290$

Fire Marshall

3000 Market Street NE, Suite 534

Salem, Oregon 97310

(503) $378-4580$

Oregon Energy Facility Siting Council

Department of Energy

625 Marion NE

Salem, Oregon 97310

(503) $378-4129$

Oregon Public Utility Commissioner

Utilities Program

Labor \& Industries Building, Room 330

Salem, Oregon 97310

(503) 378-6634

Oregon Water Resources Department

3850 Portland Road NE

Salem, OR 97310

(503) 370-3739

Oregon Department of Environmental Quality

811 SW Sixth

Portland, OR 97204

(503) 229-5696

Oregon Department of Fish and Wildlife

2501 SW First Avenue

Box 59

Portland, OR 97207

(503) 229-5400

Oregon Economic Development Department

775 Summer Street NE

Salem, OR 97310

(503) 373-1200

Cregon Department of Agriculture

Plant Conservation Biology Program

625 Capitol Street NE

Salem, OR $9731^{\wedge}-0110$

(503) 378-3810 
Columbia River Gorge Commission

288 E Jewett Boulevard

Box 730

White Salmon, WA 98672

(509) 493-3323

Oregon Department of Energy

625 Marion Street NE

Salem, OR 97310

(503) $378-4040$

Oregon Parks and Recreation Department

Vick Building

525 Trade Street SE \#301

Salem, OR 97310

(503) 378-6305

Oregon Advisory Committee on Historic Preservation

525 Trade Street SE

Salem, OR 97310

(503) 378-5001

Oregon Department of Forestry

State Board of Forestry

2600 State Street

Salem, OR 97310

(503) 378-2511

Oregon Department of Transportation

Oregon Transportation Commission

135 Transportation Building

Salem, OR 97310

(503) 378-6388

Oregon Division of State Lands

State Land Board

775 Summer Street

Salem, OR 97310

(503) $378-3850$ 
Oregon Water Resources Department District Offices

District

1

2

3

4

5

6

7

8

Baker

9

10

11

Union
Counties

Clatsop, Columbia, Tillamook, Washington

Lane, Linn

Hood River, Sherman, Wasco

Gilliam, Grant, Wheeier

Morrow, Umatilla

Wallowa

Malheur

Harney

Crook, Deschutes, Jefferson

\section{Address}

Washington County Courthouse $155 \mathrm{~N} 1$ st Avenue Hillsboro, OR 97123

(503) 681-7018

Lane County Courthouse

Environmentul Health Department $125 \mathrm{E} \mathrm{8th}$

Eugene, OR 97401

(503) $687-4011$

Wasco County Courthouse Annex A 400 E 5th

The Dalles, OR 97058

(503) 296-5494

P.O. Box 261

Canyon City, OR 97820

575-0119

3920 Westgate

Pendleton, OR 97801

276-7111

Route 1, Box 1709

La Grande, OR 97850

(503) $963-1010$

Wallowa County Courthouse

Enterprise, OR 97828

426-4216

Baker County Courthouse

1995 3rd Street

Baker, OR 97814

(503) $523-8224$ or $523-7866$

Malheur County Courthouse

Vale, OR 97918

(503) 473-5130

Harney County Courthouse

P.O. Box 1147

Burns, OR 97720

(503) $573-2591$

117 E NW Lafayette

Bend. OR 97701

(503) 388-6669 
12

Lake

13

14

15

16

17

18
Josephine

Jackson

Coos, Curry, Douglas

Clackamas, Marion, Mulmomah

Klamath

Benton, Lincoln, Polk, Yamhill
51.3 Center Street

Lakeview, OR 97630

(503) $947-6038$

Jackson Ccunty Courthouse 10 S Oakdale, Room 106 Medford, OR 97501 (503) $776-7056$

Grants Pass Municipal Building $101 \mathrm{NW}$ "A" Street Grants Pass, OR 97526 (503) 474-5385

Justice Building, Room 103 Roseburg, OR 97470 (503) $440-4255$

3850 Portland Road NE Salem, CR 97310 (503) $378-8128$

3328 Vandenberg Road Klamath Falls, OR 97603 (503) $883-4182$

3850 Portland Road NE Salem, OR 97310

(503) $378-8128$

Oregon County Planning Departments

\section{County}

Baker

Benton

Clackamas

Clatsop

Columbia

Coos

Crook

Curry

Deschutes

Douglas

Gilliam

Grant

Harney

Hood River

Jackson

Jefferson

Josephine

Klamath

Lake

Lane

Lincoln
County Seat

Baker City

Corvallis

Oregon City

Astoria

St. Helens

Coquille

Prineville

Gold Beach

Bend

Roseburg

Condon

Canyon City

Burns

Hood River

Medford

Madras

Grants Pass

Klamath Falls

Lakeview

Eugene

Newport
Telephone

523-6414

757-6819

655-8521

325-8611

397-1501

396-3121

447-3211

247-7011

388-6556

672-3311

384-4243

575-1519

$573-6655$

386-1306

776-7554

475-2317

474-542:

882-2501

947-4494

$687-4061$

265-6611 
Linn

Malheur

Marion

Morrow

Multnomah

Polk

Sherman

Tillamook

Uinatilla

Union

Wallowa

Wasco

Washington

Wheeler

Yamhill
Albany

Vale

Salem

Irrigon

Portland

Dallas

Moro

Tillamook

Pendleton

La Grande

Enterprise

The Dalles

Hillsboro

Fossil

McMinnville
967-3816

473-3185

588-5038

676-9061

248-3043

623-9237

565-3606

842-5511

276-7111

963-1014

426-3048

298-5169

648-8761

763-2911

472-9371 


\section{Washington State Agency Addresses}

Washington Department of Natural Resources

201 John A. Cherberg Building

QW-21

Olympia, WA 98504

(206) 753-5327

Geology \& Earth Resources Division

4224 Sixth Avenue SE

Rowe Six Building, PY-12

Lacey, WA 98503

(206) $459-6372$

Forest Regulation \& Assistance

$1007 \mathrm{~S}$ Washington, EL-03

Olympia, WA 98504

(206) $753-5315$

Regional Offices

Central Region

1405 Rush Road S-3

Chehalis, WA 98532

(206) 753-3410

Northeast Region

P.O. Box 190

Colville, WA 99114

(509) 684-5201

Northwest Region

919 N Township Street

Sedro Woolley, WA 98284

(206) 856-0083

Olympic Region

Route 1, Box 1375

Forks, WA 98331

(206) 374-6131

South Puget Sound Region

28329 SE 448th Street

Enumclaw, WA 98022

(206) 825-1631

Southeast Region

713 E Bowers Road

Ellensburg, WA 98926

(509) 925-6131

Southwest Region

601 Bond Road

Castle Rock, WA 98611

(206) 577-2025

Washington State Energy Office

809 Legion Way SE, P.O. Box 43165

Olympia, WA 98504-3165

(206) 459-2000

Washington Department of Ecology

Main Office

PV-11

Olympia-Lac^y, WA 98504

(206) 459-6000

Regional Offices

Eastern

N 4601 Monroe, Suite 100

Spokane, WA 99205-1295

(509) 456-2926

Central

$3601 \mathrm{~W}$ Washington

Yakima, WA 98903-1164

(509) 575-2800 
Washington Department of Fisheries

115 General Administration Building

AX-11

Olympia, WA 98504

(206) $753-6600$

Washington Parks and Recreation Commission

600 N Capitol Way, GJ-11

Olympia, WA 98504

(206) 753-5755

Washington Department of Social and Health Services

Environmental Health Division

Mail Stop LD-11

Olympia, WA 98504

(206) 753-5955

Washington Department of Wildlife

600 Capitol Way $N$

GJ-11

Olympia, WA $98501-1091$

(206) 753-5700

Washington Energy Facility Site Evaluation Council

809 Legion Way SE

FA-11

Olympia. WA $98504-1211$

(206) $956-2000$

Washington Office of Archaeological and Historic Preservation

$111 \mathrm{~W} 21$ st Avenue

KL-11

Olympia. WA 98504

(206) $753-4011$

U.S. Forest Service

1835 Black Lake Boulevard SW

Olympia, WA 98502

(206) 956-2306 


\section{Indian Tribes of the Northwest}

Idaho Indian Tribes

Chairman

Nez Perce Executive Committee

Nez Perce Tribe

P. O. Box 305

Lapwai, ID 83540

(208) 843-2253

Shoshone-Bannock Tribe

P. O. Box 306

Fort Hall, ID 83203

(208) 238-3700

\section{Montana Indian Tribes}

Assiniboine and Sioux Tribes

Fort Peck Agency

P.O. Box 1027

Poplar, MT 59255

(406) 768-5155

Confederated Salish \& Kootenai Tribes

P.O. Box 278

Pablo, MT 59855

(406) $657-2700$

Fort Belknap Community Council

P.O. Box 249

Harlem, MT 59526

(406) 353-2205

Chippewa Cree Tribe

Rocky Boy's Agency

Rocky Boy Route, Box 544

Box Eider, MT 59521

(406) $395-4478$

\section{Oregon Indian Tribes}

Confederated Tribes of Coos,

Lower Umpqua, \& Sluslaw Indians

$455 \mathrm{~S}$ 4th Street

Coos Bay, OR 97420-1570

(503) 267-5454

Coquille Indian Tribe

P.O. Box 1435

Coos Bay, OR 97420-0330

(503) 267-5454
Shoshone-Paiute Tribe of the

Duck Valley Reservation

P. O. Box 219

Owyhee, NV 89832

(702) 757-3211

Coeur d'Alene Tribal Headquarters

Sub-Agency

Plummer, ID 83851

(208) 274-3101

Blackfeet Nation

P.O. Box 846

Browning, MT 59417

(406) 338-7179

Crow Tribal Council

Box 159

Crow Agency, MT 59022

(406) 638-2601

Northern Cheyenne Tribal Council

P.O. Box 128

Lame Deer, MT 59043

(406) 477-6284
Confederated Tribes of the Grand Ronde Community of Oregon

P.O. Box 38

Grand Ronde, OR 97347-0038

(503) 879-5215

Cow Creek Band of Umpqua Tribe

2400 Stewart Parkway, Suite 300

Roseburg, OR 97470-1563

(503) 672-9405 
Siletz Tribal Council

P.O. Box 549

Siletz, OR 97380-0549

(503) 444-2532

Confederated Tribes of Warm Springs

H.C. 71

100 Pasigo Street

Burns, OR 97720-9303

(503) 573-2088

Washington Indian Tribes

Chehalis Confederated Tribes

P.O. Box 536

Oakville, WA 98568

(205) 273-5911

Hoh Tribe

HC 80 Box 917

Forks, WA 98331

(206) 374-6582

Kalispel Tribe

P.O. Box 38

Usk, WA 99180

(509) 445-1147

Lummi Tribe

2616 Kwina Road

Bellingham, WA 98226-9298

(206) 643-6242

Muckleshoot Tribe

39015 172nd Avenue SE

Auburn, WA 98002

(206) 939-3311

Nooksack Tribe

P.O. Box 157

Deming, WA 98244

(206) 592-5176

Puyallup Tribe

2002 E 28th Street

Tacoma, WA 98404

(206) $597-6200$

Quinault Tribe

P.O. Box 189

Taholah, WA 98587

(206) 276-8211
Umatilla Tribe

P.O. Box 638

Pendleton, OR 97801-0638

(503) 276-3165
Colville Confederated Tribes

P.O. Box 150

Nespelem, WA 99155

(509) 634-4763

Jamestown Klallam Tribe

305 Oly Blyn Highway

Sequim, WA 98382

(206) 683-1109

Lower Elwha Klallam Tribe 1666 Lower Elwha Road

Port Angeles, WA 98362-0298

(206) 452-8471

Makah Tribe

P.O. Box 115

Neah Bay, WA 98357

(206) 645-2205

Nisqually Tribe

4820 She-Nah-Num D. SE

Olympia, WA 98503

(206) 456-5221

Port Gamble Klallam Tribe

P.O. Box 280

Kingston, WA 98346

(206) 297-2646

Quileute Tribe

P.O. Box 279

La Push, WA 98350

(206) 374-6143

Sauk-Sueittle Tribe

5318 Chief Brown Lane

Darrington, WA 98241

(206) 436-0132 
Shoalwater Bay Tribe

P.O. Box 597

Tokeland, WA 98590

(206) 267-6766

Spokane Tribe

P.O. Box 100

Wellpinit, WA 99040

(509) 258-4591

Stillaguamish Tribe

3439 Stoluckguamish Lane

Arlington, WA 98223

(206) 435-2755

Swinomish Tribe

P.O. Box 817

LaConner, WA 98257

(206) 466-3163

Upper Skagit Tribe 2284 Community Plaza

Sedro Woolley, WA 98284

(206) 856-5501
Skokomish Tribe

N 541 Tribal Center Road

Shelton, WA 98584

(206) 877-5213

Squaxin Island Tribe

W 81 Highway 108

Shelton, WA 98584

(206) 426-9783

Suquamish Tribe

P.O. 498

Suquamish, WA 98392

(206) 598-3311

Tulalip Tribes

6700 Totem Beach Road

Marysville, WA 98270-9694

(206) 653-0223

Yakima Confederated Tribes

P.O. Box 151

Toppenish, WA 98948

(509) 865-5121 

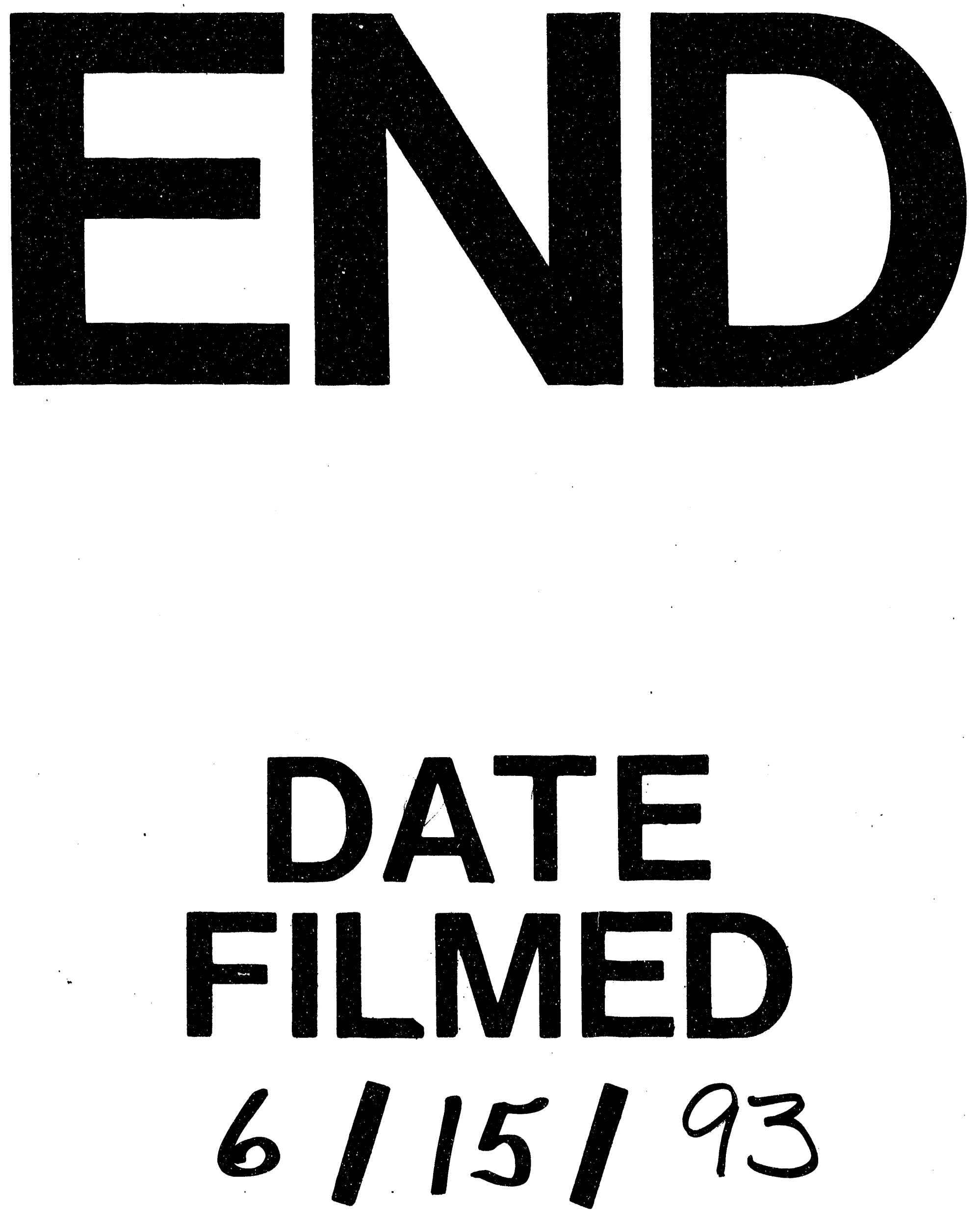
